\title{
ESTIMATED FLOOD PEAK DISCHARGES ON TWIN, BROCK, AND LIGHTNING CREEKS, SOUTHWEST OKLAHOMA CITY, OKLAHOMA, MAY 8, 1993
}

By Robert L. Tortorelli

U.S. GEOLOGICAL SURVEY

Water-Resources Investigations Report 96-4185

Prepared in cooperation with the City of Oklahoma City, Oklahoma

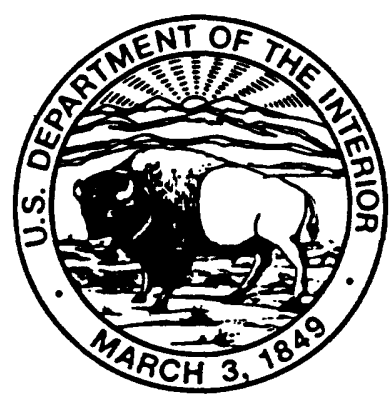

Oklahoma City, Oklahoma 1996 


\title{
U.S. DEPARTMENT OF THE INTERIOR \\ BRUCE BABBITT, Secretary
}

\author{
U.S. GEOLOGICAL SURVEY \\ GORDON P. EATON, Director
}

Any use of trade names in this publication is for descriptive purposes

only and does not Imply endorsement by the U.S. Government.

UNITED STATES GOVERNMENT PRINTING OFFICE: OKLAHOMA CITY 1996

For additional Information write to:

District Chlef

U.S. Geological Survey

Water Resources Division

202 NW 66th Street, Bullding 7

Oklahoma Clty, OK 73116
Coples of this report can be

purchased from:

U.S. Geological Survey

Branch of Information Services

Box 25286

Denver, CO 80225-0286 


\section{CONTENTS}

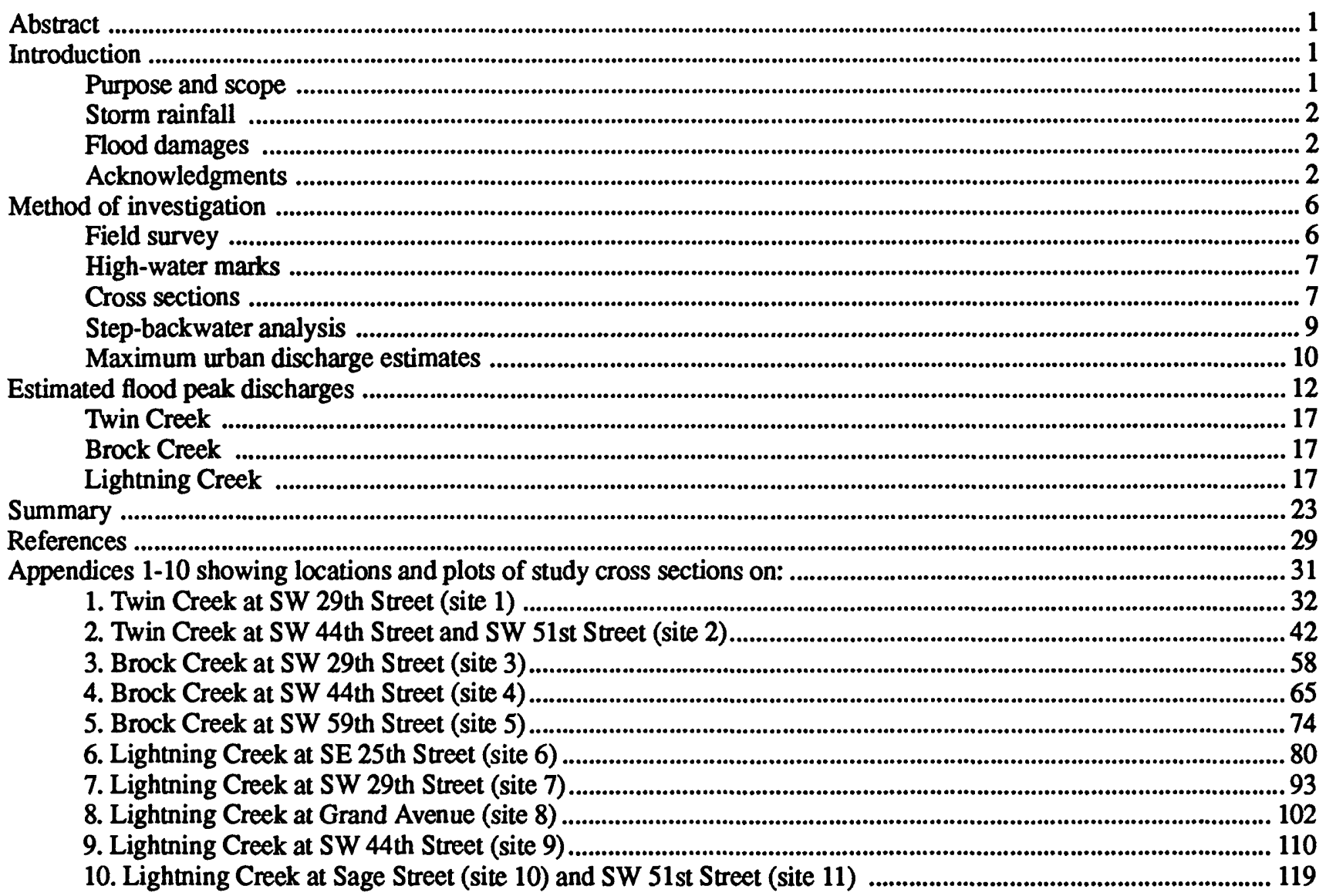

\section{ILLUSTRATIONS}

\section{Figures}

1. Map showing location of stream sites used in study, Oklahoma City, Oklahoma.

2-15 Graphs showing:

2. One-hour rainfall depths at Will Rogers Airport, Oklahoma City, Oklahoma, (data from the National Oceanic and Atmospheric Administration, 1993). .......................................................................... 4

3. Three-hour storm-rainfall frequency for Oklahoma City, Oklahoma, (data from Hershfield, 1961 and National Oceanic and Atmospheric Administration, 1993). ..............................................................5

4. Relationship of Leopold Urban Adjustment Factor, $R_{L}$, to the percentage of the area impervious, and served by storm sewer (Adapted from Leopold, 1968). ......................................................................... 11

5. Relation of the May 8, 1993, unit discharge to the upper limits of measured floods in Oklahoma. ..................... 15

6. Oklahoma City flood-insurance study floods and May 1993 flood water-surface profiles of Twin Creek

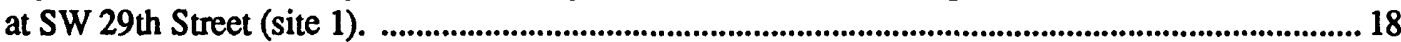

7. Oklahoma City flood-insurance study floods and May 1993 flood water-surface profiles of Twin Creek at SW 44th and SW 51st Street (site 2).

8. Oklahoma City flood-insurance study floods and May 1993 flood water-surface profiles of Brock Creek at SW 29th Street (site 3).

9. Oklahoma City flood-insurance study floods and May 1993 flood water-surface profiles of Brock Creek at SW 44th Street (site 4).

10. Oklahoma City flood-insurance study floods and May 1993 flood water-surface profiles of Brock Creek at SW 59th Street (site 5). 
11. Oklahoma City flood-insurance study floods and May 1993 flood water-surface profiles of Lightning Creek at SE 25th Street (site 6).

12. Oklahoma City flood-insurance study floods and May 1993 flood water-surface profiles of Lightning Creek at SW 29th Street (site 7).

13. Oklahoma City flood-insurance study floods and May 1993 flood water-surface profiles of Lightning Creek at Grand Avenue (site 8).

14. Oklahoma City flood-insurance study floods and May 1993 flood water-surface profiles of Lightning Creek at SW 44th Street (site 9).

15. Oklahoma City flood-insurance study floods and May 1993 flood water-surface profiles of Lightning Creek at Sage Street (site 10) and SW 51st Street (site 11).

\section{TABLES}

1. Summary of May 8, 1993, flood damages to private facilities in Twin, Brock, and Lightning Creek basins . .6

2. Elevation reference marks established during the study 8

3. Vertical control elevations established during the study and two 1990 City of Oklahoma City Global

Positioning System control monuments

4. Summary of flood peak discharge for the flood of May 8,1993

5. Hydraulic data for the May 1993 flood, Oklahoma City flood-insurance study floods, and maximum urbanization 100 -year floods

6. Culvert flows and peak discharge in Oklahoma City May 1993 flood

\section{CONVERSION FACTORS AND VERTICAL DATUM}

\begin{tabular}{rlll}
\hline Multiply & By & \multicolumn{1}{c}{ To obtain } \\
\hline & & \\
inch (in) & 25.4 & millimeters $(\mathrm{mm})$ \\
feet (ft) & 0.3048 & meters $(\mathrm{m})$ \\
mile $(\mathrm{mi})$ & 1.609 & kilometers $(\mathrm{km})$ \\
square miles $\left(\mathrm{mi}^{2}\right)$ & 2.590 & square kilometers $\left(\mathrm{km}^{2}\right)$ \\
cubic feet per second per square mile $\left[\left(\mathrm{ft}^{3} / \mathrm{s}\right) / \mathrm{mi}^{2}\right]$ & 0.01093 & cubic meters per second $\left(\mathrm{m}^{3} / \mathrm{s}\right)$ \\
cubic feet per second $\left(\mathrm{ft}^{3} / \mathrm{s}\right)$ & $\mathbf{0 . 0 2 8 3 2}$ & cubic mers per second per square $\mathrm{kilometer}\left[\left(\mathrm{m}^{3} / \mathrm{s}\right) / \mathrm{km}^{2}\right]$ \\
\hline
\end{tabular}

Sea level: In this report "sea level" refers to the National Geodetic Vertical Datum of 1929 (NGVD of 1929)-a geodetic datum derived from a general adjustment of the first-order level nets of both the United States and Canada, formerly called Sea Level Datum of 1929. 


\title{
Estimated Flood Peak Discharges on Twin, Brock, and Lightning Creeks, Southwest Oklahoma City, Oklahoma, May 8, 1993
}

\author{
By Robert L. Tortorelli
}

\section{Abstract}

The flash flood in southwestern Oklahoma City, Oklahoma, May 8, 1993, was the result of an intense 3-hour rainfall on saturated ground or impervious surfaces. The total precipitation of 5.28 inches was close to the 3-hour, 100-year frequency and produced extensive flooding. The most serious flooding was on Twin, Brock, and Lightning Creeks. Four people died in this flood. Over 1,900 structures were damaged along the 3 creeks. There were about $\$ 3$ million in damages to Oklahoma City public facilities, the majority of which were in the three basins.

A study was conducted to determine the magnitude of the May 8, 1993, flood peak discharge in these three creeks in southwestern Oklahoma City and compare these peaks with published flood estimates. Flood peak-discharge estimates for these creeks were determined at 11 study sites using a step-backwater analysis to match the flood water-surface profiles defined by high-water marks.

The unit discharges during peak runoff ranged from 881 cubic feet per second per square mile for Lightning Creek at SW 44th Street to 3,570 cubic feet per second per square mile for Brock Creek at SW 59th Street. The ratios of the 1993 flood peak discharges to the Federal Emergency Management Agency 100-year flood peak discharges ranged from 1.25 to 3.29 . The watersurface elevations ranged from 0.2 foot to 5.9 feet above the Federal Emergency Management Agency 500-year flood water-surface elevations.

The very large flood peaks in these 3 small urban basins were the result of very intense rainfall in a short period of time, close to 100 percent runoff due to ground surfaces being essentially impervious, and the city streets acting as efficient conveyances to the main channels. The unit dis- charges compare in magnitude to other extraordinary Oklahoma urban floods.

\section{INTRODUCTION}

One of the greatest flood disasters in the history of Oklahoma City, Oklahoma, occurred during the early evening hours from about 4 p.m. to 9 p.m. May 8,1993 . The flash flood was the result of an intense 3hour rainfall occurring within a 12-hour rainfall event.

The southwestern part of Oklahoma City was especially hard hit. Most of the flood damage was on Twin, Brock, and Lightning Creeks, tributaries to the North Canadian River. Flood waters claimed four lives; three people died in Brock Creek, and one person died in Lightning Creek. There was an estimated $\$ 3$ million in damage to City facilities and about 1,200 homes were damaged (Brown, 1993). It is estimated to be the worst flood in the City since the June 3,1932, flood on the North Canadian River and its tributaries that was caused, to a large extent, by Lightning Creek overflow; 3,200 people were homeless, with 5 deaths, and 7 people missing (Tortorelli, Cooter, and Schuelein, 1991).

The U.S. Geological Survey (USGS), in cooperation with the City of Oklahoma City, conducted a study to determine the magnitude of the May 8, 1993, flood peak discharge in these three creeks in southwestern Oklahoma City and compare these peaks with published flood estimates. Data presented in this report provide City officials and consultants with a technical basis to make flood-plain management decisions and assist them in deciding future courses of action on the flood-prone areas.

\section{Purpose and Scope}

The magnitudes of urban floods are seldom documented in urban areas in Oklahoma. This report pre- 
sents estimates of the flood peak discharges at 11 locations on Twin, Brock, and Lightning Creeks. These locations are small stream reaches above and below major urban street bridges and culverts, which are referred to as sites in this report. The study sites were chosen at locations of interest by the cooperator, the City of Oklahoma City. Figure 1 shows the locations of the study sites: 2 sites on Twin Creek (sites 12), 3 sites on Brock Creek (sites 3-5), and 6 sites on Lightning Creek (sites 6-11).

The flood peak discharges and computed flood water-surface profiles are compared with those of selected frequencies used in the Federal Emergency Management Agency (FEMA) flood-insurance study for Oklahoma City (Federal Emergency Management Agency, 1990). This report also compares the estimated flood peak discharges to estimated maximum discharges in an urban environment (Tortorelli and others, 1983) and upper limits of known floods in Oklahoma (Crippen and Bue, 1977; Bingham and others, 1974; Bergman and Tortorelli, 1988).

\section{Storm Ralnfall}

Rainfall was very intense for a short period of time during a longer rain event. The reported rainfall by the National Weather Service at Will Rogers Airport for the 24-hour period from 7 p.m. Friday, May 7, 1993, to 7 p.m. Saturday, May 8, 1993, was 7.04 inches (National Oceanic and Atmospheric Administration, 1993). A total rainfall of 5.28 inches fell between 3 p.m. and 6 p.m. on May 8, 1993 (figure 2). As shown in figure 2, this heavy rainfall was preceded by 0.85 inches of precipitation. Therefore, the intense rainfall fell on nearly-saturated or impervious ground surfaces, and it was assumed that almost 100 percent runoff did occur.

National Weather Service radars are capable of providing raw radar plots of cumulative rainfall. Raw radar plots are those unadjusted by surface rain gage point data. Plots of the May 8, 1993, storm were provided by the Oklahoma City Weather Forecast Office (written commun., 1993). An inspection of these raw radar plots revealed that the rainfall received by Twin and Brock Creek watersheds was nearly equal to that measured by Will Rogers Airport rain gage. The Lightning Creek study area received about 1-2 inches less.

The expected frequency of the rainfall event is usually determined by comparing the recorded rainfall amount of a specified duration with the National Weather Service Technical Paper 40 data (Hershfield, 1961). A comparison of these data is presented in figure 3. The recorded 3-hour rainfall of 5.28 inches is only 0.10 inch less than that for the 100 -year frequency, 3-hour rainfall. The concept of 100-year frequency is discussed in detail in the Estimated Flood Peak Discharges section.

\section{Flood Damages}

There were a substantial number of structures damaged in the May 8, 1993, flood in Twin, Brock, and Lightning Creeks. Table 1 shows the tally for the 3 study basins (Brown, 1993). Over 1,900 structures were damaged in the 3 basins, of which about 1,200 were homes. In addition, about $\$ 3$ million in damages to Oklahoma City public facilities were a result of the flash flood, the majority of which were in the 3 southwest urban basins.

President Clinton signed a federal disaster declaration for four counties in Oklahoma on Wednesday, May 12, 1993 (English, 1993). Oklahoma County was one of these counties, making the residents of the three study basins eligible for state and federal disaster relief.

Four people died in this flood. Three deaths were attributed to the flooding in Brock Creek, and one death occurred in Lightning Creek.

\section{Acknowledgments}

The author is indebted to many people who contributed significantly to the completion of the study. A special thanks goes to Eldon Beard of the National Weather Service, who provided rainfall data and raw radar precipitation plots. USGS personnel who assisted are: Tony Coffey and Rick Hanlon who marked the high-water marks; David Adams, Steve Smith, and Shane Hadlock who conducted the field surveys; Al Rea who provided computer expertise to generate drainage determinations and site base maps; and Lyn Osburn who provided editorial assistance. Ken Wahl, Central Region Surface-Water Specialist, provided technical expertise in the review of the hydraulic computations. This study would not have been possible without their cooperation and assistance. 
Figure 1. Location of stream sites used in study, Oklahoma City, Oklahoma. 


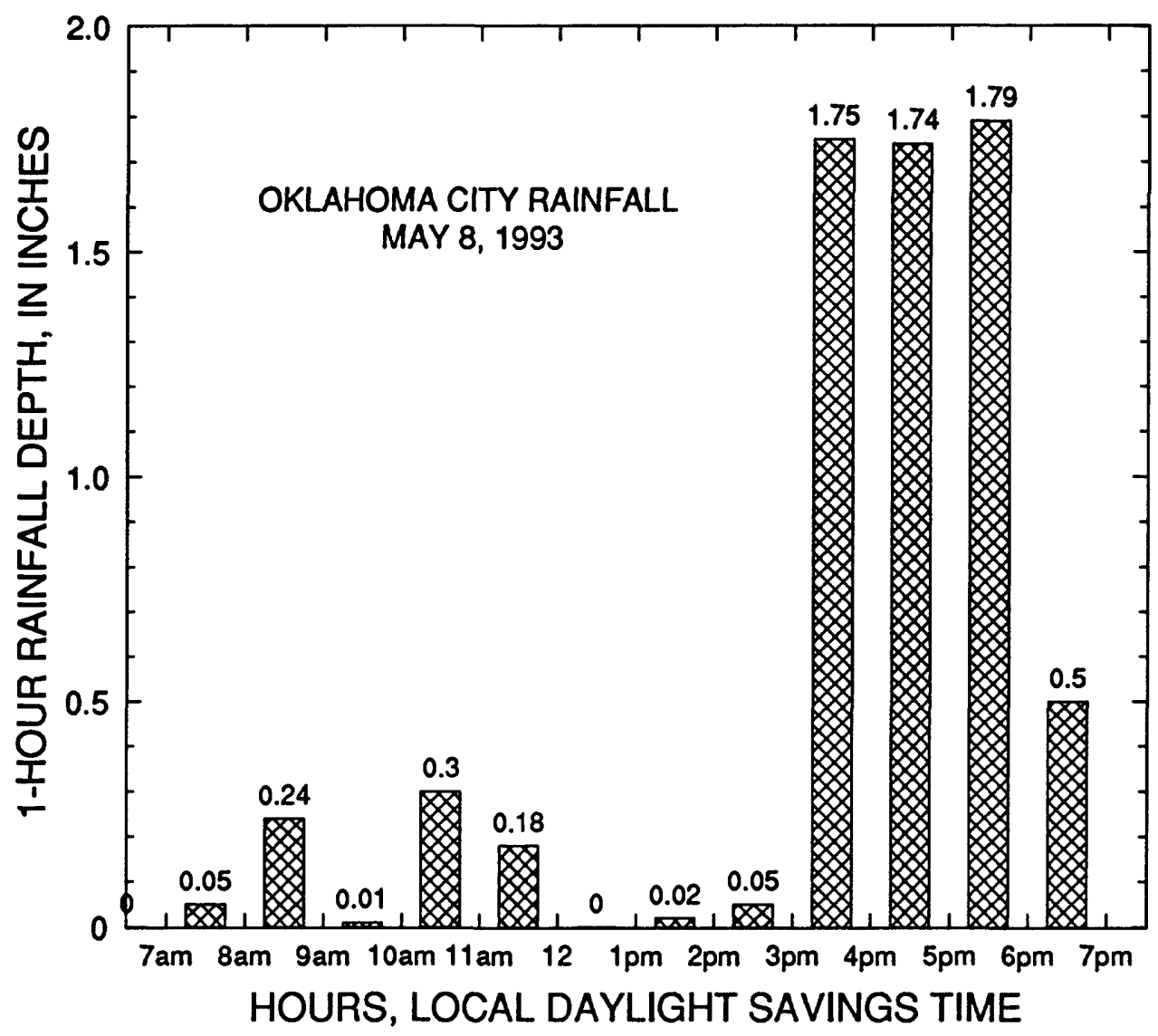

Figure 2. One-hour rainfall depths at Will Rogers Airport, Oklahoma City, Oklahoma, (data from the National Oceanic and Atmospheric Administration, 1993). 


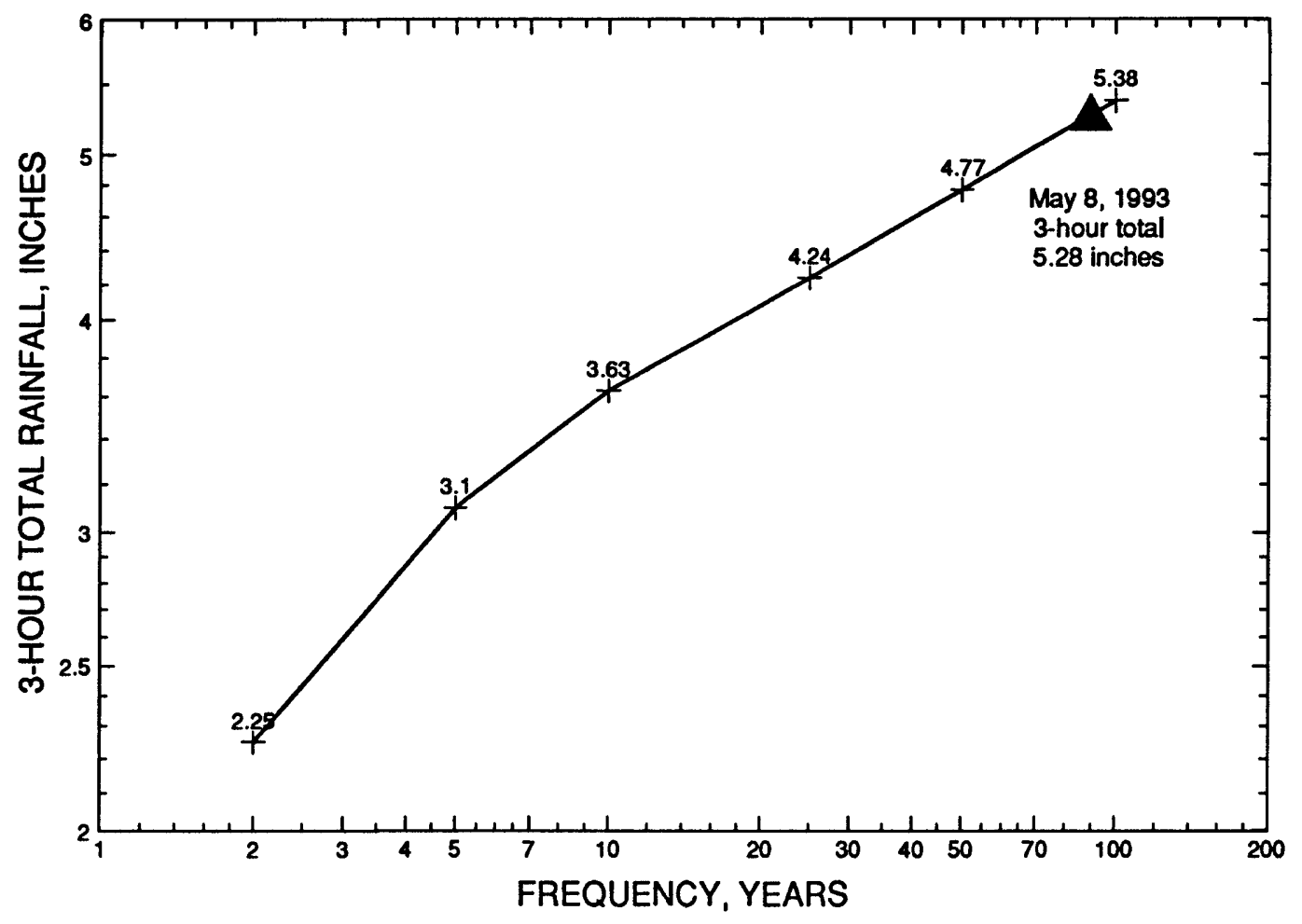

Figure 3. Three-hour storm-rainfall frequency for Oklahoma City, Oklahoma, (data from Hershfield, 1961 and National Oceanic and Atmospheric Administration, 1993). 
Table 1. Summary of May 8, 1993, flood damages to private facilities in Twin, Brock, and Lightning Creek basins

\begin{tabular}{lcccc}
\hline & \multicolumn{4}{c}{ Number of damaged structures ${ }^{1}$} \\
\cline { 2 - 5 } $\begin{array}{c}\text { Description of private } \\
\text { facility }\end{array}$ & Twin Creek & Brock Creek & Lightning Creak & Total \\
\hline Homes & 583 & 359 & 252 & 1,194 \\
Apartment Units & 0 & 383 & 0 & 383 \\
Motel Units & 0 & 14 & 0 & 14 \\
Businesses & 16 & 22 & 17 & 55 \\
Other ${ }^{2}$ & 200 & 2 & 84 & 286 \\
Total & 799 & 780 & 353 & 1,932 \\
\hline $\begin{array}{l}\text { 1. Data from Brown (1993). } \\
\text { 2. Includes 1 church, 1 food bank, 1 senior citizen home, 1 } 1 \text { highway patrol office, 82 garages and outbuildings, and 200 }\end{array}$ \\
leased storage units
\end{tabular}

\section{METHOD OF INVESTIGATION}

Many peak discharges must be determined after the passage of the flood by indirect methods (Benson and Dalrymple, 1967). This study used step-backwater analysis to match the flood water-surface profiles defined by high-water marks.

Streamflow volume or discharge is usually measured by means of a current meter. Techniques of making current-meter or direct measurements are standardized and well known (Carter and Davidian, 1968). During floods, however, it is frequently impossible or impractical to measure the peak discharges when they occur. Roads may be impassable; knowledge of the flood rise may not be available in advance to permit reaching the site near the time of the peak; structures from which current-meter measurements might have been made may be nonexistent or impassable; personnel may not be available to obtain direct measurements at numerous locations; or the peak may be of such short duration that a satisfactory currentmeter measurement could not be made.

Indirect measurements use the energy equation to estimate discharge. The specific equations used dif- fer for specific flow situations, but all methods involve these general factors (Benson and Dalrymple, 1967):

1. Physical characteristics of the channel: dimensions and conformation of the channel within the reach studied.

2. Water-surface elevations at the time of peak stage to define the upper limit of the cross-sectional areas and the fall of the water surface between two adjacent cross sections.

3. Hydraulic factors based on physical characteristics, water-surface elevations, and discharge, such as roughness coefficients and discharge coefficients.

The data required for computation of discharge by indirect methods are obtained by a field survey of a reach of channel. This includes the elevation and location of high-water marks corresponding to the peak water-surface elevation, cross sections of the channel along the reach, selection of the roughness coefficients, and description of the geometry of any culverts or bridges in the reach.

\section{Fleld Survey}

The field survey was conducted by U.S. Geological Survey personnel using a Geodimeter 440 total sta- 
tion $^{1}$. The vertical and horizontal control for the survey of the study sites was based on the FEMA reference mark RM 12-30A, Twin Creek at SW 44th Street (Federal Emergency Management Agency, 1990). All other FEMA reference marks near the study sites were destroyed prior to May 8, 1993. A baseline traverse was surveyed along SW 44th Street. Additional traverse lines were surveyed from this baseline to the other sites. Additional vertical elevation reference marks were established and are listed in table 2. A check with 1990 Oklahoma City Global Positioning System survey control monuments revealed a difference of about 0.5 foot with the original FEMA reference mark (table 3). The horizontal control was based on an arbitrary datum of 10,000 feet northing and 10,000 feet easting and a magnetic azimuth of $262^{\circ}$ down SW 44th Street at RM 12-30A. The entire study was completely integrated both vertically and horizontally.

\section{High-Water Marks}

High-water marks are evidence of the highest elevation reached by the flood. There are many different types of marks including seed lines and mud lines on fences, trees, posts, and buildings; and drift on bushes, and stream banks. The proper identification of the marks requires experience, and should be accomplished as quickly as possible after the flood so as not to be lost to subsequent rains.

There are two labels on the high-water marks identified in this study. A field crew dispatched two weeks after the flood marked high-water marks with nails, lumber crayons, paint, stakes, and flagging. These were recorded in site notes and are referred to as flagged high-water marks. The survey crew, which surveyed from July through October 1993, noted and surveyed several additional high-water marks while in the process of surveying the study sites. These were high-quality marks of seed or mud lines on buildings, or were elevations pointed out by local residents. These are referred to as unflagged high-water marks.

Several high-water marks on both banks were identified throughout the study reaches for a considerable distance upstream and downstream from the

\footnotetext{
1. Any use of trade, product, or firm names is for descriptive purposes only and does not imply endorsement by the U.S. Government.
}

bridge or culvert at the major urban street at each site to assist in the interpretation of the profiles. Plan views were plotted of each study site to assign stream stationing locations of all high-water marks on the stream profile. Stream stationing is the longitudinal distance along the stream channel from a reference point, in this study the distance upstream from the stream mouth. As was expected, there was a certain amount of scatter in the high-water mark profile. The slope determined by these high-water marks is probably very nearly parallel to that of the water-surface elevation at the time of the flood peak (Benson and Dalrymple, 1967).

\section{Cross Sections}

Cross sections were surveyed at each study site, including the geometry of bridges and culverts. Several cross sections were used at each study site to properly represent the cross-sectional geometry of the reach and thus ensure a good definition of the watersurface profile. There were two to three times as many cross sections used in this study than were used in the FEMA flood-insurance study (1990), and each cross section had at least two times as many points defining the cross section. The cross sections also are believed to be more accurate since they were all ground-surveyed instead of defined by aerial photographs as was done in the original FEMA flood-insurance study. Care was taken to locate the cross sections as nearly as possible at right angles to the direction of flow. Since many of the study sites were highly urbanized, the location of buildings were modeled on several cross sections so that the buildings could be included in the hydraulic models.

Photographs were taken at the time of the field survey at cross-sectional locations to aid in the determination of roughness coefficients. Recent digital aerial photographs were utilized to ensure average conditions were modeled when choosing roughness coefficients.

Plan views of each study site were plotted to determine the stream stationing locations of the cross sections on the stream profiles. Care was taken to match stream stationing used in the FEMA floodinsurance study to allow later comparisons. Appendices contain the plan view of each study site showing 
Tabie 2. Elevation reference marks established during the study

[ft, feet; NGVD, National Geodetic Vertical Datum of 1929]

\begin{tabular}{|c|c|c|c|c|}
\hline $\begin{array}{c}\text { Site } \\
\text { number }\end{array}$ & $\begin{array}{l}\text { Stream name and } \\
\text { location }\end{array}$ & $\begin{array}{l}\text { Reference } \\
\text { mark }\end{array}$ & $\begin{array}{c}\text { Elevation } \\
(\mathrm{ft}, \mathrm{NGVD})^{1}\end{array}$ & Description of location \\
\hline & Twin Creek & & & \\
\hline 1 & SW 29th Street & RM 93-TN01 & $1,219.77$ & $\begin{array}{l}\text { Chiseled " } \square \text { " on the top of the southeast wingwall next to south } \\
\text { (upstream) headwall of the Twin Creek SW 29th Street culvert. }\end{array}$ \\
\hline \multirow[t]{2}{*}{2} & SW 44th Street & $\mathrm{RM} 12-30 \mathrm{~A}^{2}$ & $1,235.85$ & $\begin{array}{l}\text { Chiseled "X" on the center of the north (downstream) headwall of } \\
\text { the Twin Creek SW 44th Street culvert. }\end{array}$ \\
\hline & Brock Creek & & & \\
\hline \multirow[t]{3}{*}{3} & SW 29th Street & RM 93-BK02 & $1,204.22$ & $\begin{array}{l}\text { Chiseled " } \square \text { " } 10 \text { feet east of the west end of the south (upstream) } \\
\text { headwall of the Brock Creek SW } 29 \text { th Street culvert. }\end{array}$ \\
\hline & & RM 93-BK04 & $1,204.10$ & $\begin{array}{l}\text { Chiseled " } \square \text { " on the east end of the north (downstream) headwall } \\
\text { of the Brock Creek SW 29th Street culvert. }\end{array}$ \\
\hline & & RM 93-BK05 & $1,203.93$ & $\begin{array}{l}\text { Chiseled "X" on the center of the north (downstream) headwall of } \\
\text { the Brock Creek SW 29th Street culvert. }\end{array}$ \\
\hline 4 & SW 44th Street & RM 93-BK01 & $1,221.63$ & $\begin{array}{l}\text { Chiseled "X" on the center of the south (upstream) headwall of the } \\
\text { Brock Creek SW 44th Street culvert. }\end{array}$ \\
\hline \multirow[t]{2}{*}{5} & SW 59th Street & RM 93-BK03 & $1,243.68$ & $\begin{array}{l}\text { Chiseled "X" on the center of the south (upstream) headwall of the } \\
\text { Brock Creek SW 59th Street culvert. }\end{array}$ \\
\hline & Lightning Creek & & & \\
\hline 6 & SE 25th Street & RM 93-LG07 & $1,186.12$ & $\begin{array}{l}\text { Chiseled "X" on the south wingwall } 7 \text { feet east of the east (down- } \\
\text { stream) headwall of } 4 \text {-opening exit of the Lightning Creek SE 25th } \\
\text { Street culvert. }\end{array}$ \\
\hline 7 & SW 29th Street & RM 93-LG06 & $1,196.32$ & $\begin{array}{l}\text { Chiseled " } \square \text { " on the northeast corner of the north (downstream) } \\
\text { walkway of the Lightning Creek SW 29th Street bridge. }\end{array}$ \\
\hline 8 & Grand Avenue & RM 93-LG05 & $1,199.64$ & $\begin{array}{l}\text { Chiseled " } \square \text { " on the top of the northeast corner of the north } \\
\text { (downstream) curb of the Lightning Creek Grand Boulevard } \\
\text { bridge. }\end{array}$ \\
\hline \multirow[t]{2}{*}{9} & SW 44th Street & RM 93-LG01 & $1,206.34$ & $\begin{array}{l}\text { Chiseled " } \square \text { " on the northeast corner of the north (downstream) } \\
\text { walkway of the Lightning Creek SW 44th Street bridge. }\end{array}$ \\
\hline & & RM 93-LG02 & $1,197.90$ & $\begin{array}{l}\text { Chiseled “ } \square \text { " on the southeast corner of the east (upstream) walk- } \\
\text { way of the Lightning Creek Santa Fe Avenue bridge at SW 41st } \\
\text { Street. }\end{array}$ \\
\hline 10 & Sage Street & RM 93-LG03 & $1,206.12$ & $\begin{array}{l}\text { Chiseled " } \square \text { " on the northeast corner of the east (downstream) } \\
\text { walkway of the Lightning Creek Sage Street bridge. }\end{array}$ \\
\hline 11 & SW 51st Street & RM 93-LG04 & $1,207.25$ & $\begin{array}{l}\text { Chiseled " } \square \text { " on the southwest corner of the south (upstream) } \\
\text { walkway of the Lightning Creek SW 51st Street bridge. }\end{array}$ \\
\hline
\end{tabular}

1. NGVD is used to be consistent with previous flood-insurance study data.

2. Original flood study reference mark, study elevations based on this mark. 
Table 3. Vertical control elevations established during the study and two 1990 City of Oklahoma City Global Positioning System control monuments

[ft, feet; GPS, Global Positioning System; NGVD, National Geodetic Vertical Datum of 1929]

\begin{tabular}{cccc}
\hline $\begin{array}{c}\text { City of Oklahoma } \\
\text { City GPS control } \\
\text { monuments }\end{array}$ & $\begin{array}{c}\text { GPS } \\
\text { elevation } \\
(\mathrm{ft}, \mathrm{NGVD})^{1}\end{array}$ & $\begin{array}{c}\text { Study } \\
\text { elevation } \\
(\mathrm{ft}, \mathrm{NGVD})^{1}\end{array}$ & \multicolumn{1}{c}{ Description of location } \\
\hline $\begin{array}{c}\text { Station no. } \\
260\end{array}$ & $1,234.09$ & $1,233.50$ & $\begin{array}{l}\text { Monument cap 2,250 ft east of the intersection of Westem Avenue } \\
\text { and SW 44th Street 11.31 feet north of north SW 44th Street curb. }\end{array}$ \\
285 & $1,249.91$ & $1,249.44$ & $\begin{array}{l}\text { Monument cap 1,050 ft east of the intersection of May Avenue and } \\
\text { SW 44th Street about 2 feet north of south end of private drive } \\
\text { island in line with north SW 44th Street curb. }\end{array}$ \\
\hline
\end{tabular}

1. NGVD is used to be consistent with previous flood-insurance study data.

cross sectional stream stationing followed by crosssectional plots. Appendices 1 and 2 have Twin Creek sites (site 1-2), appendices 3-5 have Brock Creek sites (sites 3-5) and appendices 6-10 have Lightning Creek sites (sites 6-11).

\section{Step-Backwater Analysis}

The peak discharges on the study sites were determined by using step-backwater analysis to match the water-surface profile defined by the high-water marks, essentially a curve-fitting technique. The technique is an iterative process where several stage-discharges are modeled until the best fit is achieved.

Almost all open-channel flows are both unsteady (depth at a point varies with time) and nonuniform (depth changes from point to point along a channel). Steady, uniform flow is assumed for step-backwater analysis. The assumption of steadiness is justified by the fact that at peak flows the discharge hydrograph flattens out and flow approximates steady conditions even though these peak flows were of short duration (less than 1 hour). High-water marks are left along the channel by these relatively steady, peak flows. Uniformity of flow is achieved by dividing the channels into shorter lengths that are considered reasonably uniform between cross sections, both on the basis of high-water marks and on channel geometry (Davidian, 1984).
Step-backwater analysis has been long recognized as a valid method in estimating stage-discharge relations in natural channels (Bailey and Ray, 1966; Druse, 1982). Davidian (1984) recognized that it is an acceptable technique for indirect measurements in natural channels. The study sites have all or part of the reach in heavily urbanized areas, including frequent bridges or culverts. Step-backwater analysis was used to conduct the FEMA (1990) City of Oklahoma City flood-insurance study and has the capability to model bridges and culverts. Therefore, it is reasonable to use the method to estimate the discharge associated with the water-surface profile of the May 8, 1993, flood.

The step-backwater computer program used for the study is WSPRO (a computer model for Water Surface PROfile computations, Shearman, 1990). Several cross sections were used at each study site to ensure a good definition of the tailwater downstream of the culverts or bridges at the major urban street locations of the study sites and a good definition of the headwater in the ponded conditions upstream of these structures.

Emphasis was placed on matching the computed watersurface profile to the high-water marks upstream of the structures, because the structures probably provide the most reliable control of the urban stage-discharge relations.

Care was taken in the subdivision of roughness coefficients in cross-sectional subsections as recommended by Davidian (1984). There was an extreme 
variance in roughness in most of the study cross sections, ranging from smooth concrete to dense trees and underbrush. This requires a large number of subsections, and these conditions produce very large velocity head coefficients (alphas) if left uncorrected in the computer model. Large velocity head coefficients result in a lower than reasonable water-surface profile or higher estimated flood discharge. Where this was a concern, the roughness coefficients of the main channel subsections were composited, or weighted by cross-sectional area at flood elevation, to produce a single roughness coefficient and subsection. This method also was used in the overbank subsections, if deemed necessary.

The buildings were coded into the geometry of several of the study cross sections to accurately model the urban cross-sectional conditions. The buildings were thus superimposed on the basic shape of the cross sections. This was done to ensure that both the reduced cross-sectional areas and the very large wetted perimeters actually present would be modeled. The plots of the cross sections used in the study are presented in the appendices.

To ensure that the cross-section stationing of the cross-sectional points was the most accurate possible, a computer program written by David Dunn (written commun., 1994) was used. Cross-section stationing is the horizontal distance along the cross-section line from an arbitrary reference point. The program converts the cross-sectional point output from the Geodimeter $\mathbf{4 4 0}$ total station to a WSPRO format and trigonometrically fits all points to a straight line defined by the end points of the cross section. This ensures accurate cross-sectional area computation.

The starting discharge for each high-water mark water-surface elevation at the furthest downstream cross section was computed by the slope-conveyance method (Shearman, 1990) at all study sites in Twin and Brock Creeks (sites 1-5). The FEMA flood insurance study streambed slope was used (Federal Emergency Management Agency, 1990). The sites were too far apart to run each creek as a single reach.

The Lightning Creek study sites (sites 6-11) were run essentially as a continuous reach since they were close enough together to model in sufficient detail, but discharge was permitted to change within the overall reach. The starting discharge for the highwater mark water-surface elevation at the furthest downstream cross section of the furthest downstream study site (site 6) was computed by the slope-convey- ance method. Then each site upstream (sites 7-11) utilized the last cross section of the study site downstream as the starting water-surface elevation. A slope-conveyance computation was run on sites 7-11 as a check to ensure this water-surface elevation was reasonable.

At each of the culvert sites (sites 1-6), WSPRO culvert routines were run separately using the highwater marks as tailwater and headwater elevations and then those discharges were subtracted from total discharge to obtain over-the-road flows. Bridge routines were tried at those sites with bridges (sites 6-11). If excessive road overflow warning messages were given in the WSPRO output (at all sites except site 9), road and bridges were treated as a composite section (Shearman, 1990).

\section{Maximum Urban Discharge Estimates}

The maximum urban discharge estimates that were compared with the May 8, 1993, peak discharge estimates were derived by using the urban regression equations described in Thomas and Corley (1977). The urban peak discharge estimates can be interpolated between the rural peak discharge estimates (lower limiting discharges) and the peak discharge estimates for a completely developed urban basin (upper limiting discharges). This interpolation for intermediate stages of development is based on an urban adjustment factor, $R_{L}$, defined by Leopold (1968) as a ratio of the urban 2-year peak discharge to the rural 2-year peak discharge. Figure 4, adapted from Leopold (1968) by Sauer (1974), illustrates the relationship between $R_{L}$ and the percentage of the basin that is: (1) impervious and (2) served by storm sewers.

The rural or undeveloped flood peak discharge estimates $\left(R_{L}=1\right)$ can be estimated from Thomas and Corley (1977). Full urban development discharges in Oklahoma City stream basins were previously estimated using $R_{L}=4.1$ (Tortorelli and others, 1983). The completely developed urban flood discharges may be computed using $R_{L}=7$, which assumes 100 -percent runoff (Tortorelli and others, 1983). 
Figure 4. Relationship of Leopold Urban Adjustment Factor, $R_{L}$, to the percentage of the area impervious, and served by storm sewer (Adapted from Leopold, 1968). 


\section{ESTIMATED FLOOD PEAK DISCHARGES}

The rate of discharge of a stream is the volume of water that passes a given location in a specific period of time. The peak discharge rates at the selected study locations are expressed in cubic feet per second $\left(\mathrm{ft}^{3} / \mathrm{s}\right)$ and represent the discharge occurring at the time of maximum flood stage (water-surface elevation).

Flood peak discharges for the May 8, 1993, flood estimated for the 11 study sites along Twin, Brock, and Lightning Creeks by indirect methods using step-backwater analysis ranged from $6,000 \mathrm{ft}^{3} / \mathrm{s}$ for Twin Creek at SW 44th Street (site 2) to 15,000 $\mathrm{ft}^{3} / \mathrm{s}$ for Lightning Creek from SE 25th Street to Grand Avenue (sites 6-8). Unit discharge, which generally is expressed in cubic feet per second per square mile $\left[\left(\mathrm{ft}^{3} / \mathrm{s}\right) / \mathrm{mi}^{2}\right]$, is an indication of runoff intensity. Unit discharges during peak runoff ranged from 881 $\left(\mathrm{ft}^{3} / \mathrm{s}\right) / \mathrm{mi}^{2}$ for Lightning Creek at SW 44th Street (site 9) to $3,570\left(\mathrm{ft}^{3} / \mathrm{s}\right) / \mathrm{mi}^{2}$ for Brock Creek at SW 59th Street (site 5). Flood peak discharges, with corresponding unit discharges for each of the 11 sites, are listed in table 4.

Recurrence interval, as applied to floods, is the average interval of time a given flood magnitude will be equaled or exceeded once. For example, a flood with a 100-year recurrence interval has a 1 in 100 chance, on the average, of occurring in any given year, or an average frequency of 1 in 100 years. The fact that a major flood occurs in one year does not decrease the probability of a flood as great or greater occurring within the same year. Similarly, if a 100-year flood occurs in a given year, there is still a 1 in 100 chance that a similar flood will occur in subsequent years. Peak discharges and flood profiles for the 100-year flood have been developed and published in the Flood Insurance Study for the City of Oklahoma City (Federal Emergency Management Agency, 1990).

Flood peak discharges for the May 8, 1993, flood determined for the 11 study sites were compared by ratio to those discharges used to develop the FEMA 100-year flood profiles. At all sites the peak discharges exceeded the FEMA 100-year flood discharges. The 100-year flood peak discharge comparisons (table 4) ranged from 1.25 (site 9) to 3.29 (site 1).

The water-surface elevations for the May 8 , 1993, flood for the 11 study sites were compared to those of the FEMA 100- and 500-year flood profiles (table 5). The May 8, 1993, flood water-surface eleva- tions ranged from $0.2 \mathrm{ft}$ (site 4) to 5.9 feet (site 8) above the FEMA 500-year flood water-surface elevations. At all sites the flood water-surface elevations exceeded the FEMA 500-year water-surface elevations.

The flood peak discharges for the May 8, 1993, flood determined for the 11 study sites were compared to the maximum urban discharge estimates (table 5). At all sites the peak discharges exceeded that of the 100-year flood with a $R_{L}=4.1$, except at site 9 . At 7 of the 11 sites the peak discharges exceeded or equaled that of the 100 -year flood with a $R_{L}=7.0$. This suggests that the very large flood peaks were the result of close to 100 -percent runoff in the study stream basins. Not only were the ground surfaces essentially impervious, but the city streets acted as efficient conveyances to the main channel (similar to storm sewers or tributary channels).

Crippen and Bue (1977) developed an envelope curve on the basis of maximum floods in the Oklahoma, Texas, Missouri, and Kansas region (Region 9, p. 11). Unit peak discharges of the May 8, 1993, Oklahoma City, Oklahoma, flood and other extraordinary urban floods that have occurred in Oklahoma are compared to a modified maximum flood envelope curve (figure 5). Unit peak discharges from the Enid, Oklahoma, flood (Bingham and others, 1974) and Tulsa, Oklahoma, flood (Bergman and Tortorelli, 1988) were shown to illustrate that high unit peak discharges of similar magnitudes have occurred.

Another comparison (table 6) shows that at sites where culverts pass the flow under a major city street, the culverts were overwhelmed by the flood flows (sites 1-6). In all cases, the culverts were drowned out with submerged outlets (type 4 flow, Bodhaine, 1968). These structures had less than normal flow efficiency, forcing an even greater flow into street overflow.

The very large flood peaks in these 3 small urban creeks were the result of very intense rainfall in a short period of time, close to 100 -percent runoff in the study stream basins, essentially impervious ground surfaces, and the city streets acting as efficient conveyances to the main channels. All drainage structures, culverts, and bridges were assumed to be free and unobstructed in the computation of the flood peak discharges. The high-water marks defined the flood water-surface profile and elevations; however, it is unknown to what degree the drainage structures were obstructed by such things as sections of stockade 
Table 4. Summary of flood peak discharge for the flood of May 8,1993

$\left[\mathrm{mi}^{2}\right.$ square mile; $\mathrm{ft}^{3} / \mathrm{s}$, cubic feet per second; $\left(\mathrm{ft}^{3} / \mathrm{s}\right) / \mathrm{mi}^{2}$, cubic feet per second per square mile

\begin{tabular}{|c|c|c|c|c|c|c|c|}
\hline \multirow[b]{3}{*}{$\begin{array}{c}\text { Site } \\
\text { number }\end{array}$} & \multicolumn{4}{|c|}{ Indirect discharge measurements } & \multirow{2}{*}{\multicolumn{2}{|c|}{$\begin{array}{c}\begin{array}{c}\text { Oklahoma City } \\
\text { flood-insurance study }\end{array} \\
100 \text {-year }\end{array}$}} & \multirow[b]{3}{*}{$\begin{array}{c}\text { Ratio of flood } \\
\text { peak discharge } \\
\text { to } 100 \text {-year } \\
\text { flood-insurance } \\
\text { study peak } \\
\text { discharge }\end{array}$} \\
\hline & \multirow[b]{2}{*}{$\begin{array}{l}\text { Stream name and } \\
\text { location }\end{array}$} & \multirow[b]{2}{*}{$\begin{array}{c}\text { Drainage } \\
\text { area }^{2} \\
\left(\mathrm{mi}^{2}\right)\end{array}$} & \multicolumn{2}{|c|}{ May 8, 1993, flood } & & & \\
\hline & & & $\begin{array}{c}\text { Peak } \\
\text { discharge } \\
\left(\mathrm{ft}^{3} / \mathrm{s}\right)\end{array}$ & $\begin{array}{c}\text { Unit } \\
\text { discharge } \\
{\left[\left(\mathrm{ft}^{3} / \mathrm{s}\right) / \mathrm{mi}^{2}\right]}\end{array}$ & \multirow[t]{2}{*}{$\begin{array}{c}\text { Peak } \\
\text { discharge } \\
\left(\mathrm{ft}^{3} / \mathrm{s}\right)\end{array}$} & $\begin{array}{c}\text { Unit } \\
\text { discharge } \\
{\left[\left(\mathrm{ft}^{3} / \mathrm{s}\right) / \mathrm{mi}^{2}\right]}\end{array}$ & \\
\hline & Twin Creek & & & & & & \\
\hline 1 & SW 29th Street & 3.23 & 10,000 & 3,100 & 3,040 & 941 & 3.29 \\
\hline \multirow[t]{2}{*}{2} & SW 44th Street & 2.73 & 6,000 & 2,200 & 3,040 & 1,110 & 1.97 \\
\hline & Brock Creek & & & & & & \\
\hline 3 & SW 29th Street & 4.74 & 12,000 & 2,530 & 5,210 & 1,100 & 2.30 \\
\hline 4 & SW 44th Street & 3.24 & 10,000 & 3,090 & 4,040 & 1,250 & 2.48 \\
\hline \multirow[t]{2}{*}{5} & SW 59th Street & 2.24 & 8,000 & 3,570 & 2,460 & 1,100 & 3.25 \\
\hline & Lightning Creek ${ }^{3}$ & & & & & & \\
\hline 6 & SE 25th Street & 13.90 & 15,000 & 1,080 & 8,020 & 577 & 1.87 \\
\hline 7 & SW 29th Street & 13.60 & 15,000 & 1,100 & 8,020 & 590 & 1.87 \\
\hline 8 & Grand Avenue & 12.70 & 15,000 & 1,180 & 8,020 & 631 & 1.87 \\
\hline 9 & SW 44th Street & 11.35 & 10,000 & 881 & 8,020 & 707 & 1.25 \\
\hline 10 & Sage Street & 8.42 & 10,000 & 1,190 & 5,420 & 644 & 1.85 \\
\hline 11 & SW 51st Street & 8.12 & 10,000 & 1,230 & 5,420 & 667 & 1.85 \\
\hline
\end{tabular}

1. Federal Emergency Management Agency (1990)

2. Determined from 7.5 minute quadrangle Digital Elevation Models, U.S. Geological Survey (1990)

3. Discharges are reduced by detention ponds. 


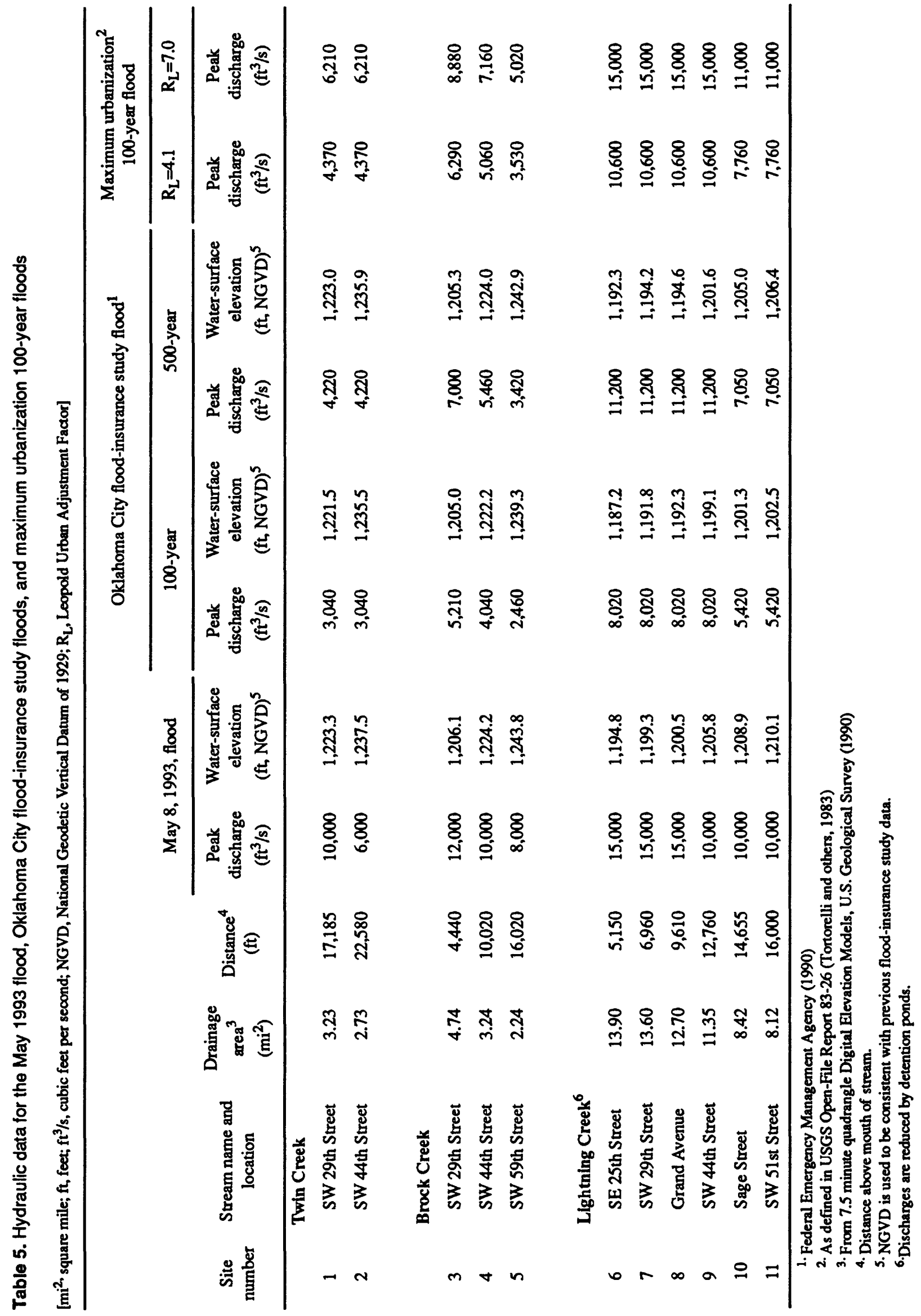




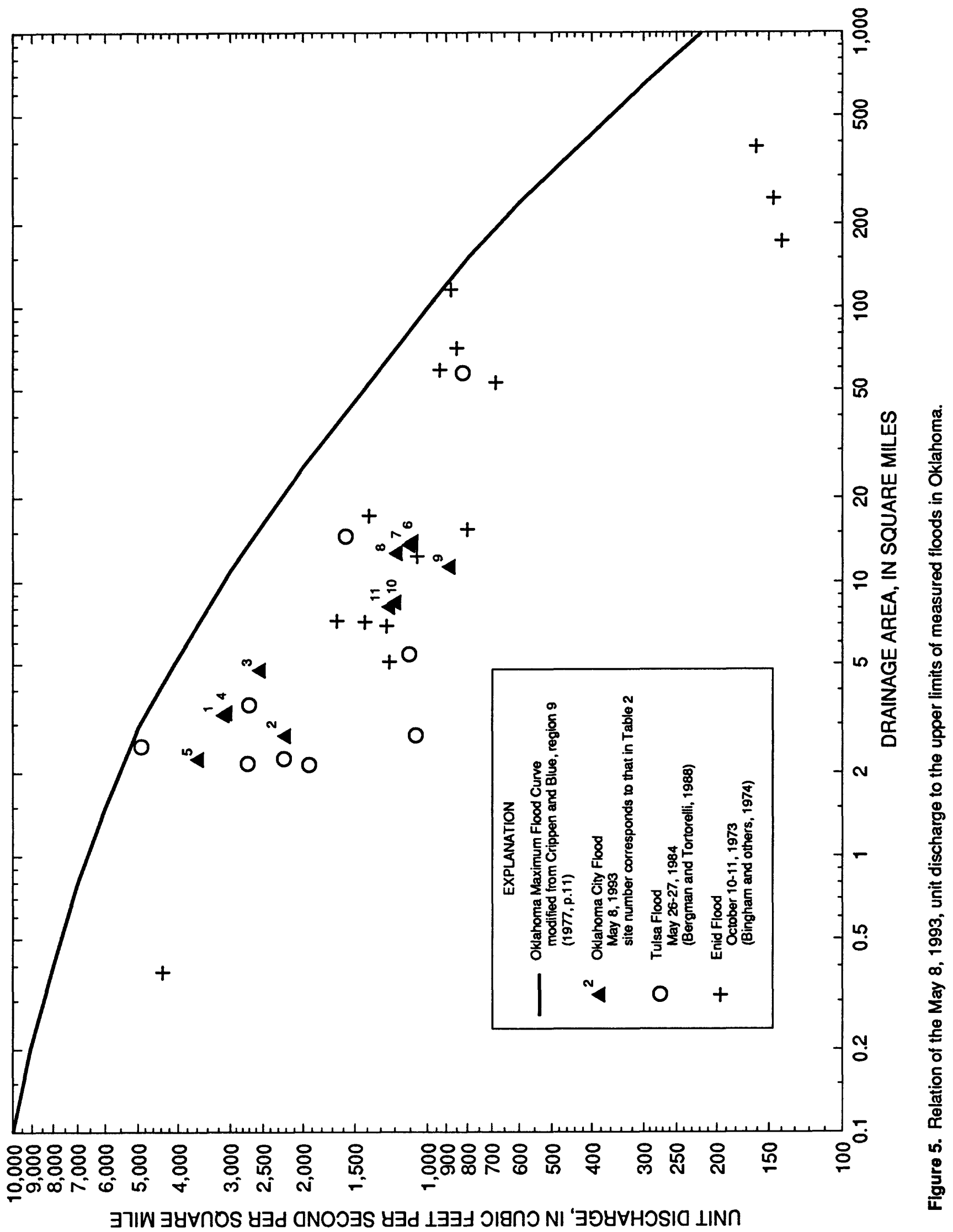


Table 6. Culvert flows and peak discharge in Oklahoma City May 1993 flood

[ft, feet; $\mathrm{ft}^{3} / \mathbf{s}$, cubic feet per second]

\begin{tabular}{|c|c|c|c|c|}
\hline \multirow[b]{2}{*}{$\begin{array}{c}\text { Site } \\
\text { number }\end{array}$} & \multirow[b]{2}{*}{$\begin{array}{l}\text { Stream name and } \\
\text { location }\end{array}$} & \multirow[b]{2}{*}{$\begin{array}{l}\text { Distance } \\
\text { (ft) }\end{array}$} & \multicolumn{2}{|c|}{ May 8, 1993, flood } \\
\hline & & & $\begin{array}{c}\text { Culvert flows }{ }^{2} \\
\qquad\left(\mathrm{ft}^{3} / \mathrm{s}\right)\end{array}$ & $\begin{array}{c}\text { Peak discharge } \\
\qquad\left(\mathrm{ft}^{3} / \mathrm{s}\right)\end{array}$ \\
\hline & Iwin Creek & & & \\
\hline 1 & SW 29th Street & 15,985 & 1,700 & 10,000 \\
\hline \multirow[t]{2}{*}{2} & SW 44th Street & 22,590 & 1,000 & 6,000 \\
\hline & Brock Creek & & & \\
\hline 3 & SW 29th Street & 4,250 & 4,500 & 12,000 \\
\hline \multirow[t]{3}{*}{4} & SW 44th Street & & & 10,000 \\
\hline & SW 43rd Street & 9,675 & 750 & \\
\hline & SW 44th Street & 9,955 & 750 & \\
\hline \multirow[t]{2}{*}{5} & SW 59th Street & 15,895 & 1,250 & 8.000 \\
\hline & Lightning Creek & & & \\
\hline \multirow[t]{4}{*}{6} & SE 25th Street & & & 15,000 \\
\hline & Short 4-Opening & 4,675 & 6,800 & \\
\hline & Long 2-Opening & 3,550 & 3,800 & \\
\hline & Total & & 10,600 & \\
\hline
\end{tabular}

\footnotetext{
1. Distance above mouth of stream

2.Submerged outlet, Type 4 flow (Bodhaine, 1968)
} 
fences, automobiles, and other debris that were observed floating down the creeks by local residents.

The May 8, 1993, flood water-surface profiles and the FEMA flood water-surface profiles (Federal Emergency Management Agency, 1990) differ in two aspects: the slope of the profile and the elevation of the profile. The differences can be attributed to differences in cross-sectional geometry, roughness coefficients, and number of cross sections used to define the FEMA step-backwater model. The FEMA cross sections were fewer per stream mile and were defined using aerial photography rather than land surveys.

There was no discernible pattern in the profile slope differences between the May 8, 1993, flood and the FEMA floods among the sites. The FEMA discharges for the 100-year flood were substantially less than the May 8, 1993, discharges (table 5). Along Twin Creek (figs. 6-7) and Brock Creek (figs. 8-10) the FEMA flood profiles were very close to and sometimes higher than the May 8, 1993, flood profiles. Along Lightning Creek (figs. 11-15) the FEMA flood profiles were much lower than the May 8, 1993, flood profiles.

\section{Twin Creek}

There are 2 study sites on Twin Creek: SW 29th Street (site 1), and SW 44th Street (site 2). The SW 29th Street study site was substituted for a proposed study site at Grand Avenue due to lack of high-water marks. The May 8, 1993, flood peak discharge was estimated to be $10,000 \mathrm{ft}^{3} / \mathrm{s}$ at site 1 and $6,000 \mathrm{ft}^{3} / \mathrm{s}$ at site 2 (table 4). The ratio of the peak discharge to that of the 100-year flood-insurance study peak ranged from 1.97 to 3.29 (table 4).

The water-surface profiles of these sites are presented in figure 6 (site 1) and figure 7 (site 2). The difference between the FEMA 500-year water-surface profiles and the May 8, 1993, flood ranged from 0.3 to 1.6 feet (table 5). Both sites have long underground culverts and had a considerable amount of overland flow in streets and buildings. Most of the flood flow at site 1 was overland between SW 27th and SW 29th Streets, and most the flood flow at site 2 was overland between SW 44th and SW 51st Streets. There is a dip in the high-water marks at site 2 above SW 44th Street that is probably due to high-water marks being identified on the fences along the alley above the concretecapped culvert in this part of the profile. The local velocity in this subsection was probably higher than the average profile velocity. Natural water surfaces are not level across a cross section, but step-backwater computations assume a level average water surface across a cross section.

\section{Brock Creek}

There are 3 study sites on Brock Creek: SW 29th Street (site 3), SW 44th Street (site 4), and SW 59th Street (site 5). The May 8, 1993, flood peak discharge was estimated to be $12,000 \mathrm{ft}^{3} / \mathrm{s}$ at site 3 , $10,000 \mathrm{ft}^{3} / \mathrm{s}$ at site 4 , and $8,000 \mathrm{ft}^{3} / \mathrm{s}$ at site 5 (table 4). The ratio of the peak discharge to that of the 100-year flood-insurance study peak ranged from 2.30 to 3.25 (table 4). According to a local resident on Binkley Street, this was the highest flood in about 48 years. Another local resident, on SW 43rd Street, said this was the highest flood since 1937, when it reached Youngs Boulevard west of the channel.

The water-surface profiles of these sites are presented in figure 8 (site 3), figure 9 (site 4), and figure 10 (site 5). The difference between the FEMA 500year water-surface elevations and the May 8, 1993, flood ranged from 0.2 to 0.9 feet (table 5). The flood flow at site 3 was mostly confined to the main channel, park land, and adjacent streets. Sites 4 and 5 had a considerable amount of overland flow in streets and buildings. Site 4 had a large amount of damage to apartment units in addition to homes downstream from SW 44th Street.

\section{Lightning Creek}

There are 6 study sites on Lightning Creek: SE 25th Street (site 6), SW 29th Street (site 7), Grand Avenue (site 8), SW 44th Street (site 9), Sage Street (site 10), and SW 51st Street (site 11). The May 8, 1993, flood peak discharge was estimated to be 15,000 $\mathrm{ft}^{3} / \mathrm{s}$ at sites 6-8, and $10,000 \mathrm{ft}^{3} / \mathrm{s}$ at sites 9-11 (table 4). The ratio of the peak discharge to that of the 100-year flood-insurance study peak ranged from 1.25 to 1.87 (table 4). Local residents in the lower part of Lightning Creek said this was the worst flooding they had seen in 37 years. Another local resident, on SW 43rd Street, said this was the highest flood since 1945.

The flood was relatively less severe than in Twin and Brock Creeks due to less rainfall; large, improved, and well-maintained main channels (espe- 


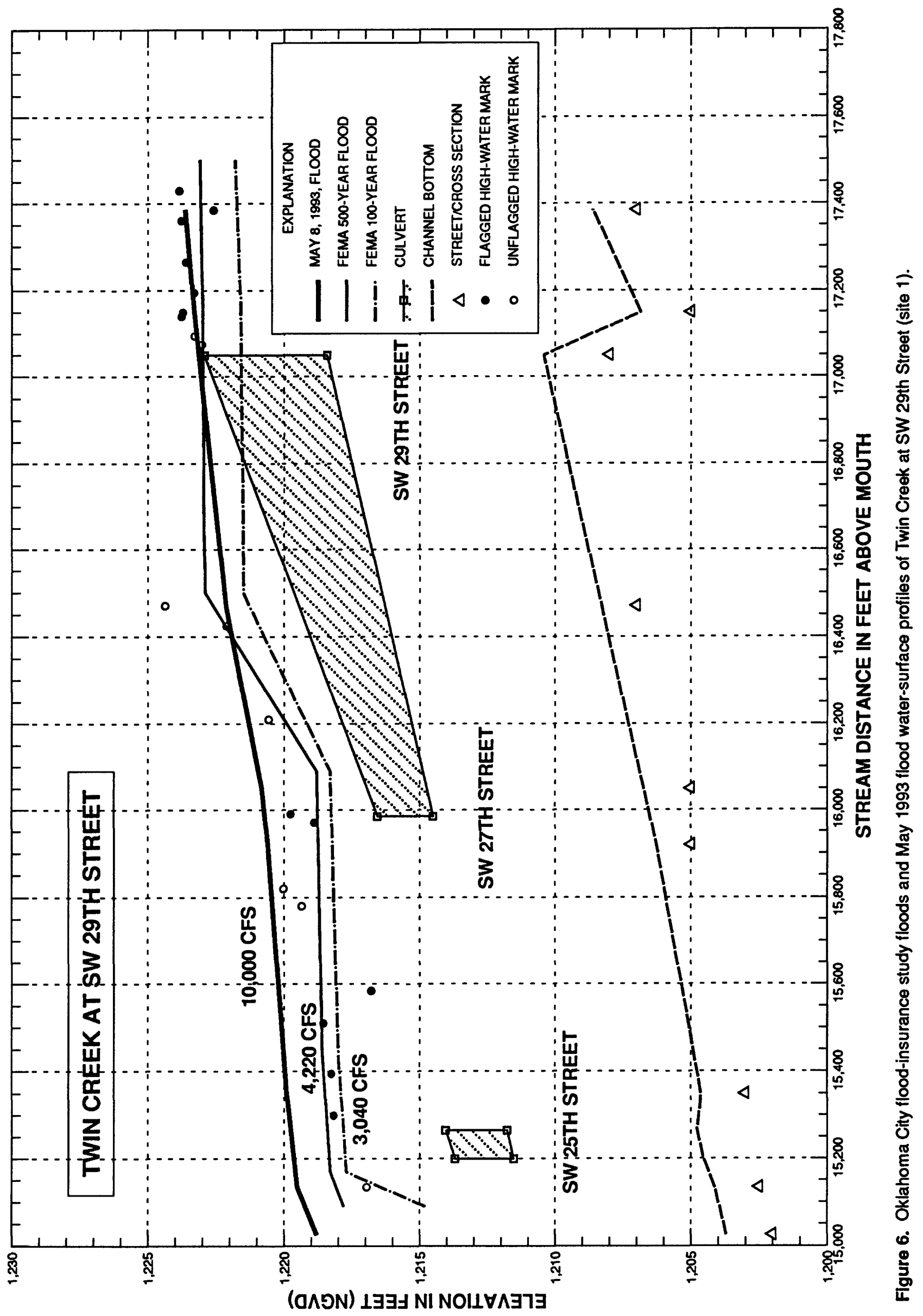




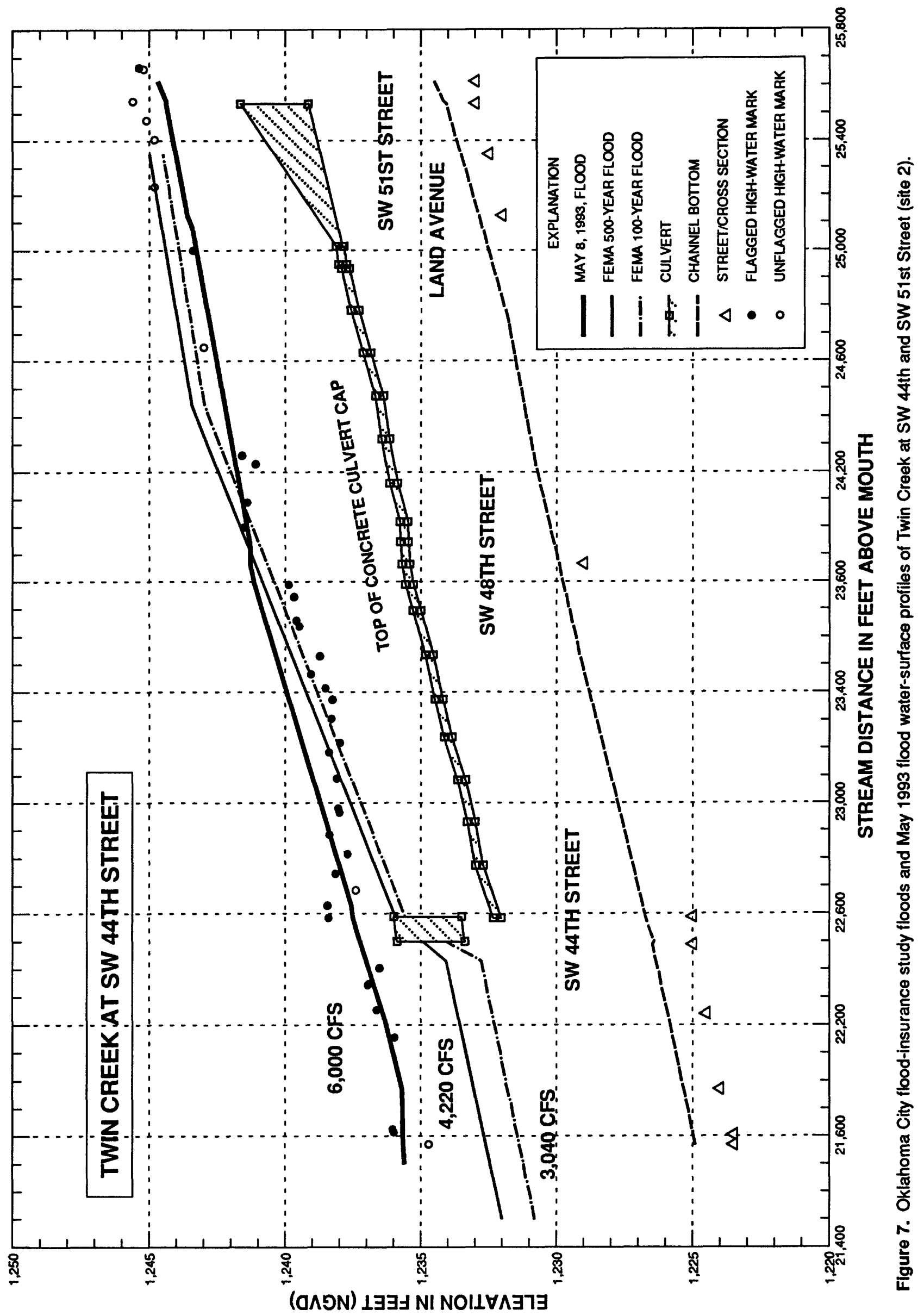




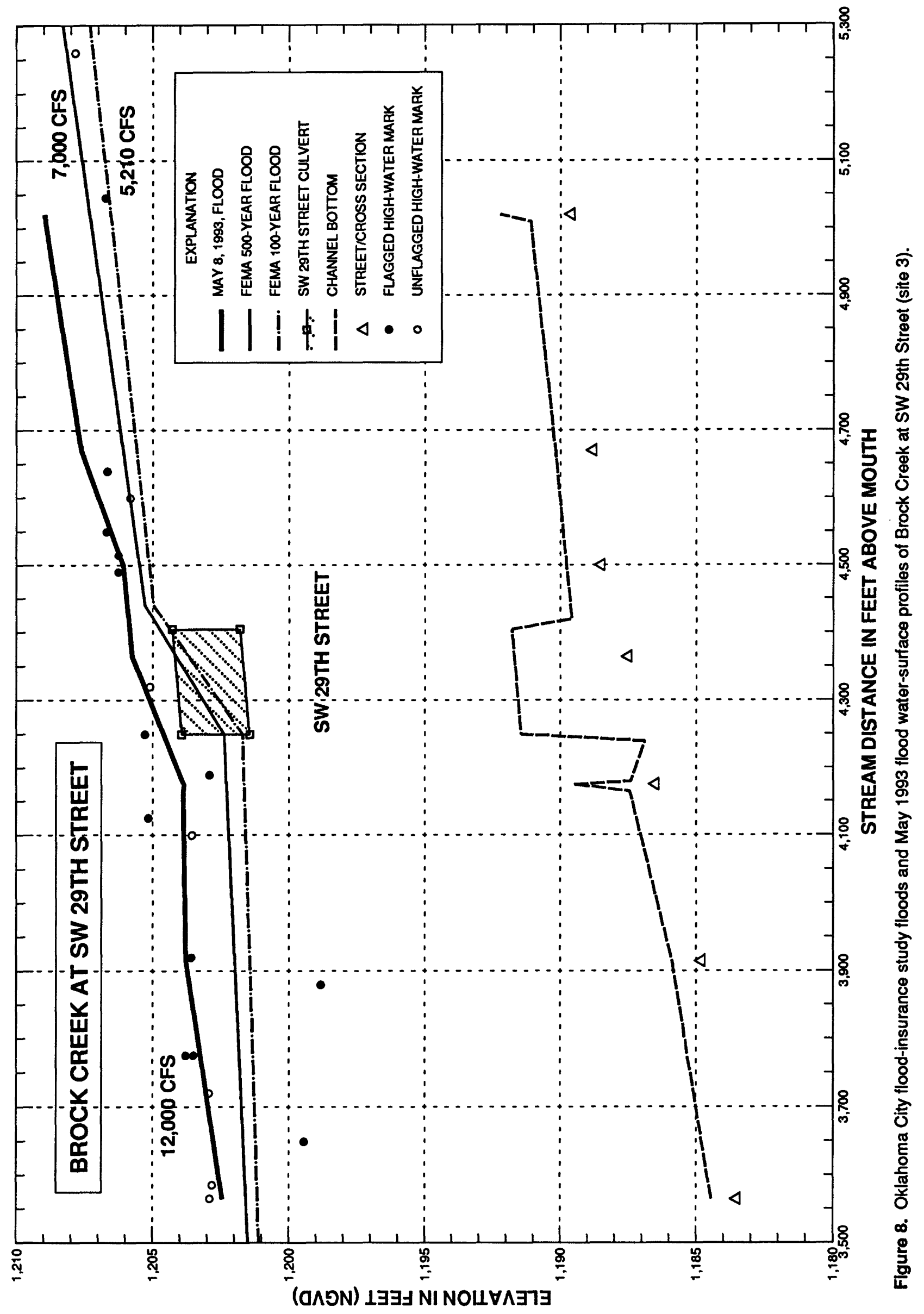




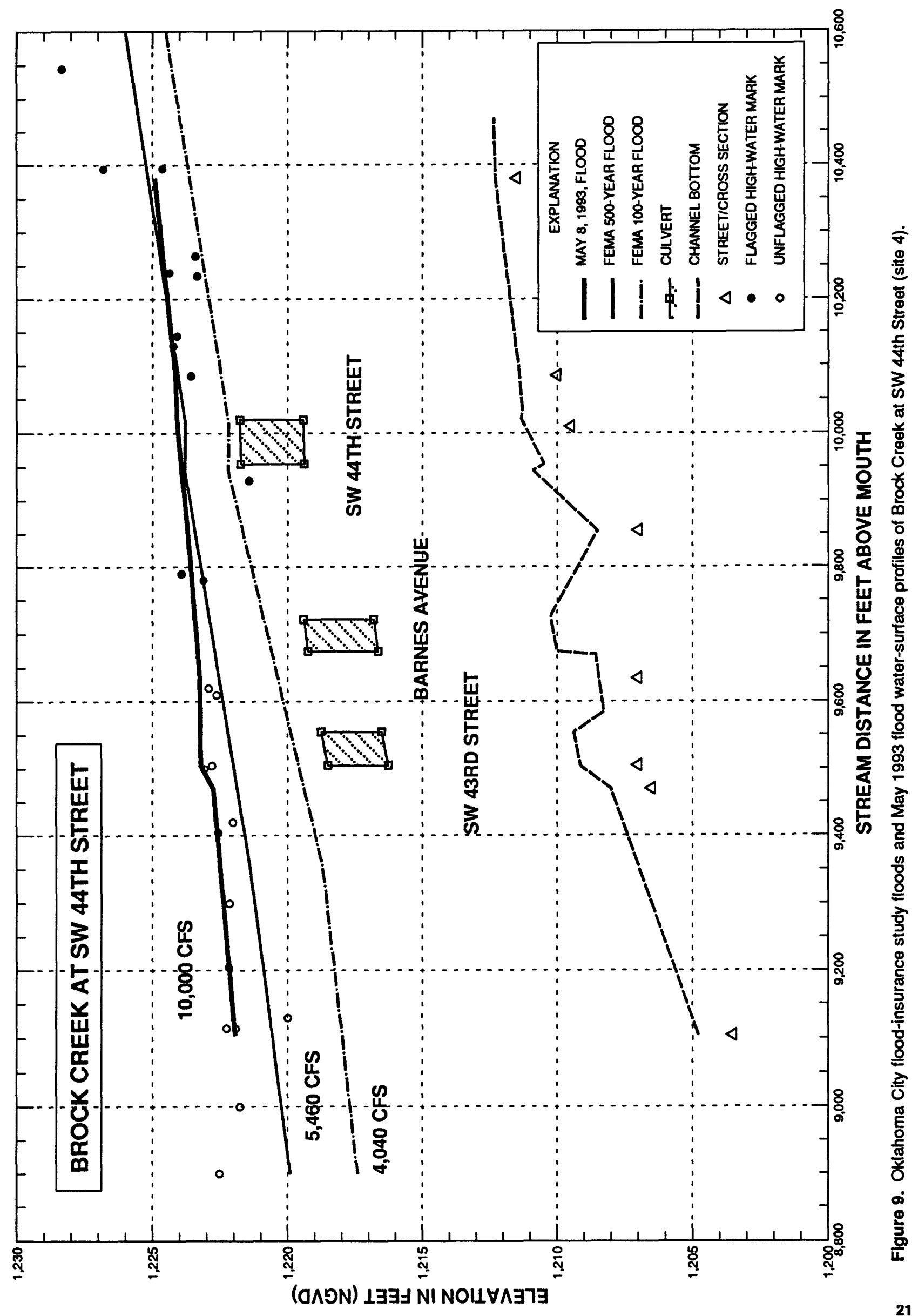




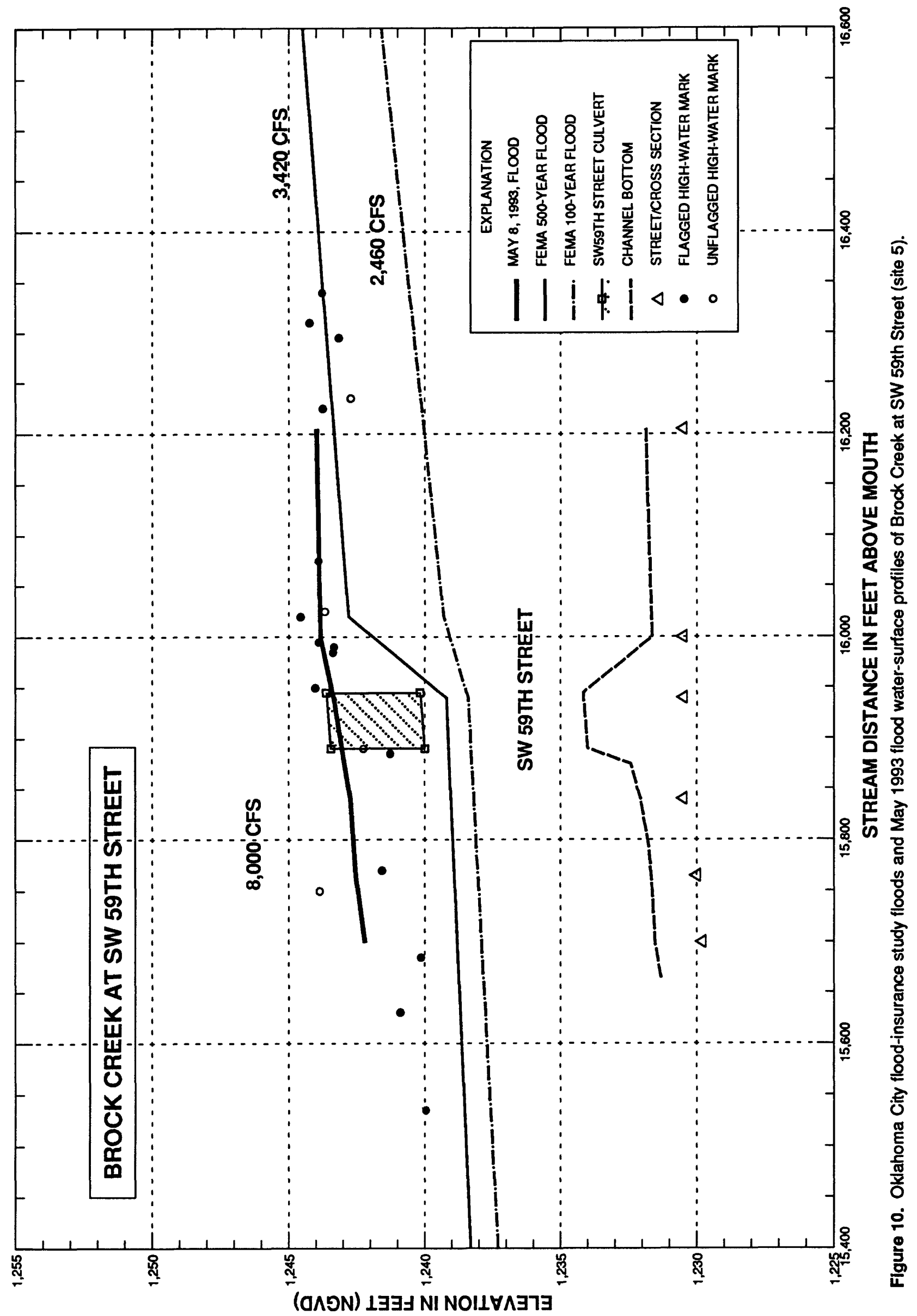


cially above SW 29th Street); and detention ponds in the upper end of the drainage basin. However, there is a large constriction due to the encroachment of commercial buildings just below SW 29th Street and dense growths of trees and brush line the main channel banks starting downstream from SW 29th Street.

The water-surface profiles of these sites are presented in figure 11 (site 6), figure 12 (site 7), figure 13 (site 8), figure 14 (site 9), and figure 15 (sites 10 and 11). The difference between the FEMA 500-year water-surface profiles and the May 8, 1993, flood ranged from 2.5 to 5.9 feet (table 5). Site 6 had a large, long underground culvert with four openings that exit east of the railroad downstream from SE 25th Street and two openings that exit downstream from SE 23rd Street. Other study sites on Lightning Creek had bridges. Sites 6-8 had a considerable amount of overland flow in streets and buildings. Sites 9-11 had some overland flow in streets and buildings.

There was a major reduction of discharge between site 8 (Grand Avenue) and site 9 (SW 44th Street) from $15,000 \mathrm{ft}^{3} / \mathrm{s}$ to $10,000 \mathrm{ft}^{3} / \mathrm{s}$. This was modeled by reducing the peak to $12,000 \mathrm{ft}^{3} / \mathrm{s}$ at the last upstream cross section of site 8 and then reducing the peak to $10,000 \mathrm{ft}^{3} / \mathrm{s}$ at the first cross section of site 9. This apparent discharge reduction shown by highwater mark data may be attributed to 3 factors: (1) there are 3 small tributaries (or large storm sewers) that enter the main channel between Grand Avenue and SW 44th Street; (2) rainfall was greater north of SW 44th Street; (3) detention structures are located on the upper end of Lightning Creek.

\section{SUMMARY}

The flash flood in southwestern Oklahoma City, Oklahoma, May 8, 1993, was the result of an intense 3-hour rainfall occurring within a 12-hour rainfall event. A total rainfall of 5.28 inches fell between 3 p.m. and 6 p.m. at Will Rogers Airport. The recorded rainfall was close to the 100-year frequency, 3-hour rainfall. This intense rainfall that fell on nearly saturated ground or impervious surfaces, was assumed to result in almost 100-percent runoff, and produced extensive flooding.

The most serious flooding was on Twin, Brock, and Lightning Creeks, tributaries to the North Canadian River. A study was conducted to determine the magnitude of the May 8, 1993, flood peak discharge in these three creeks in southwestem Oklahoma City and compare these peaks with published flood estimates. Flood peak-discharge estimates for the May 8, 1993, flood were determined for 11 study sites along these creeks. These were determined by an indirect method using step-backwater analysis to match the flood water-surface profiles defined by high-water marks.

Four people died in this flood. Three deaths were attributed to the flooding in Brock Creek, and one death occurred on Lightning Creek. Over 1,900 structures were damaged in the 3 basins, of which about 1,200 were homes. In addition, there were about $\$ 3$ million in damages to Oklahoma City public facilities, the majority of which were in the three basins. Oklahoma County was declared a federal disaster area.

The unit discharge during peak runoff at the indirect-measurement sites ranged from 881 cubic feet per second per square mile $\left[\left(\mathrm{ft}^{3} / \mathrm{s}\right) / \mathrm{mi}^{2}\right]$ for Lightning Creek at SW 44th Street (site 9) to $3,570\left(\mathrm{ft}^{3} / \mathrm{s}\right) / \mathrm{mi}^{2}$ for Brock Creek at SW 59th Street (site 5). The ratios of the 1993 flood peak-discharges determined for the 11 study sites to those discharges used to develop the FEMA flood-insurance study 100-year flood profiles ranged from 1.25 (site 9) to 3.29 (site 1). At all sites the peak discharges exceeded the FEMA 100-year flood discharges, and the flood water-surface elevations at the study sites ranged from $0.2 \mathrm{ft}$ (site 4) to 5.9 feet (site 8) above the FEMA 500-year flood watersurface elevations.

The flood peak discharges for the 11 study sites were compared to the maximum urban discharge estimates, and to extraordinary urban floods in Oklahoma. The peak discharges at 7 of the 11 sites exceeded or equaled that of the 100 -year flood with a $R_{L}=7.0$. This suggests that the very large flood peaks were the result of close to 100 percent runoff in the study stream basins. Unit peak discharges for the 1993 flood were comparable to those for other extraordinary urban floods in Oklahoma.

The differences in profile slope and water-surface elevation between May 8, 1993, flood water-surface profiles and the FEMA flood water-surface profiles can be attributed to differences in cross-sectional geometry, roughness coefficients, and number of cross sections used to define the FEMA step-backwater model. In addition, it is unknown to what degree the drainage structures were obstructed.

The very large flood peaks in these 3 small urban basins were the result of very intense rainfall in 


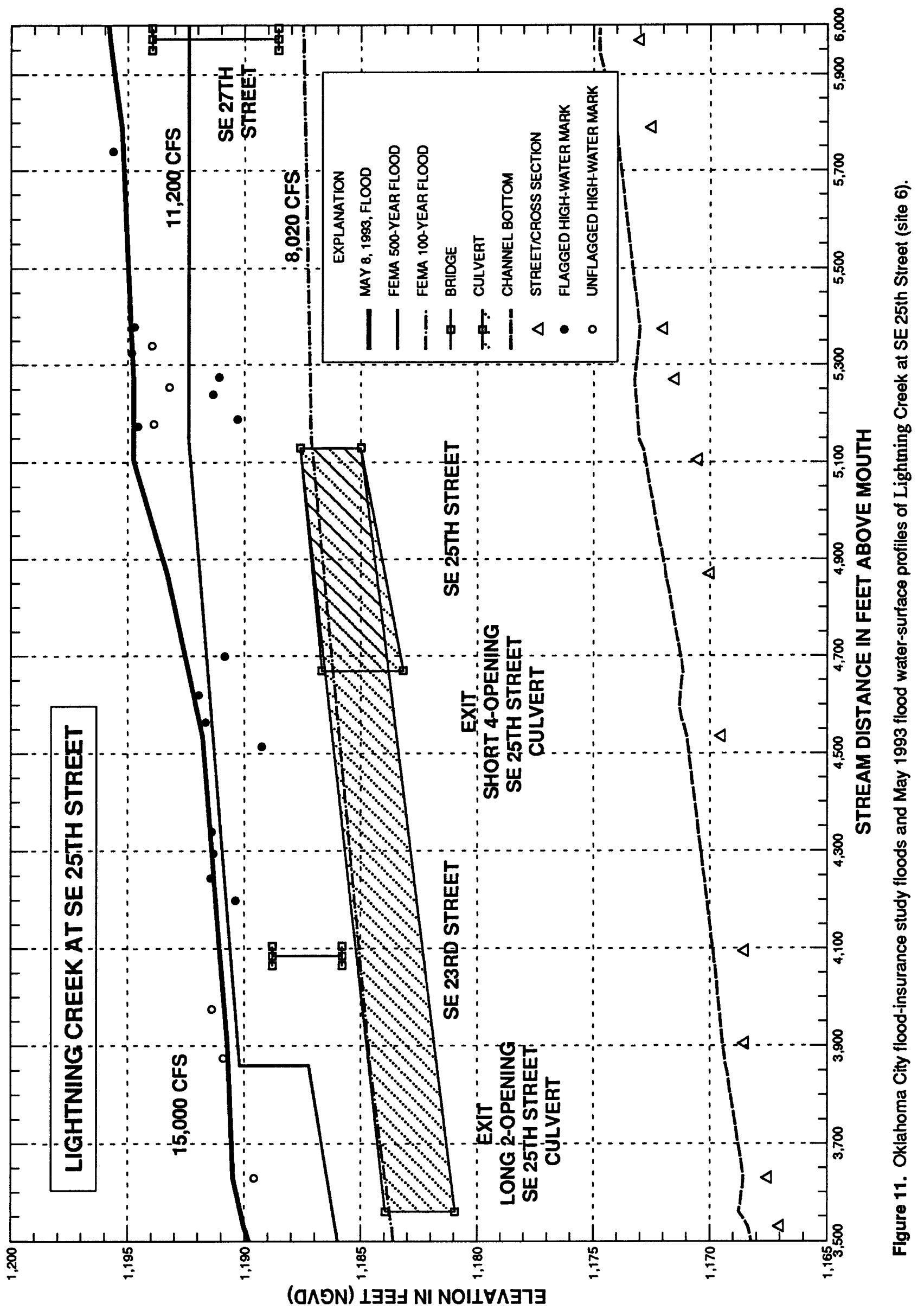




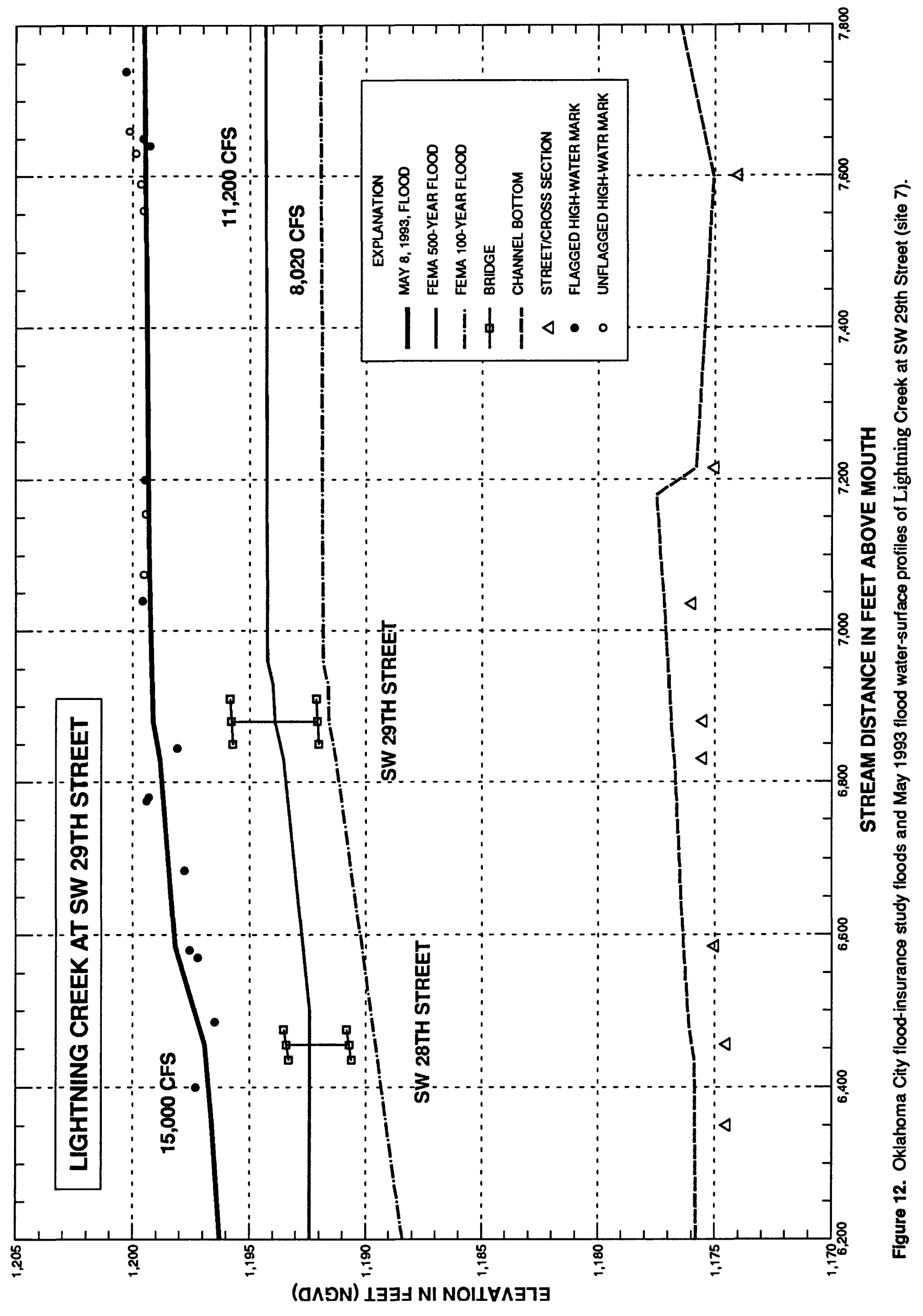




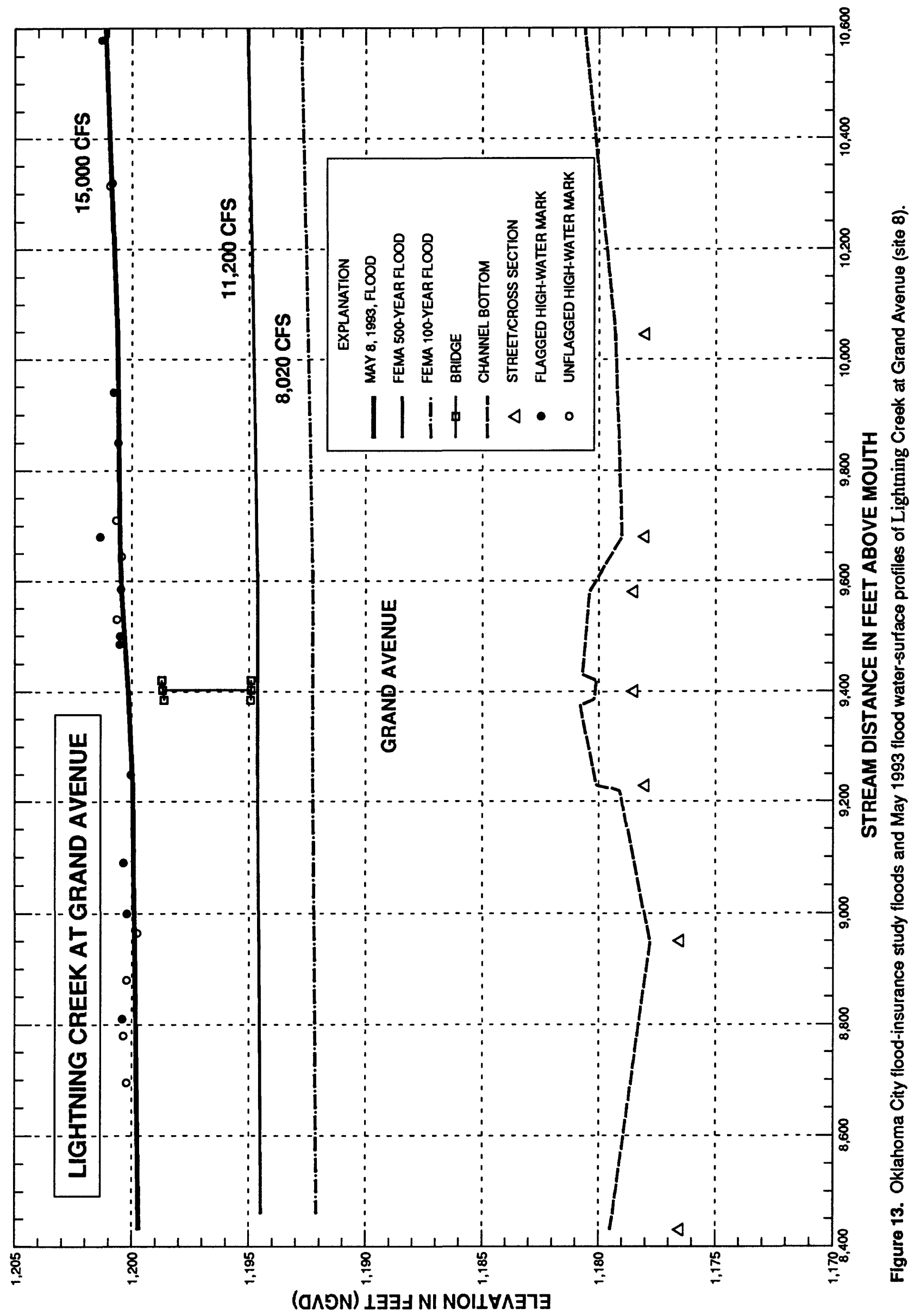




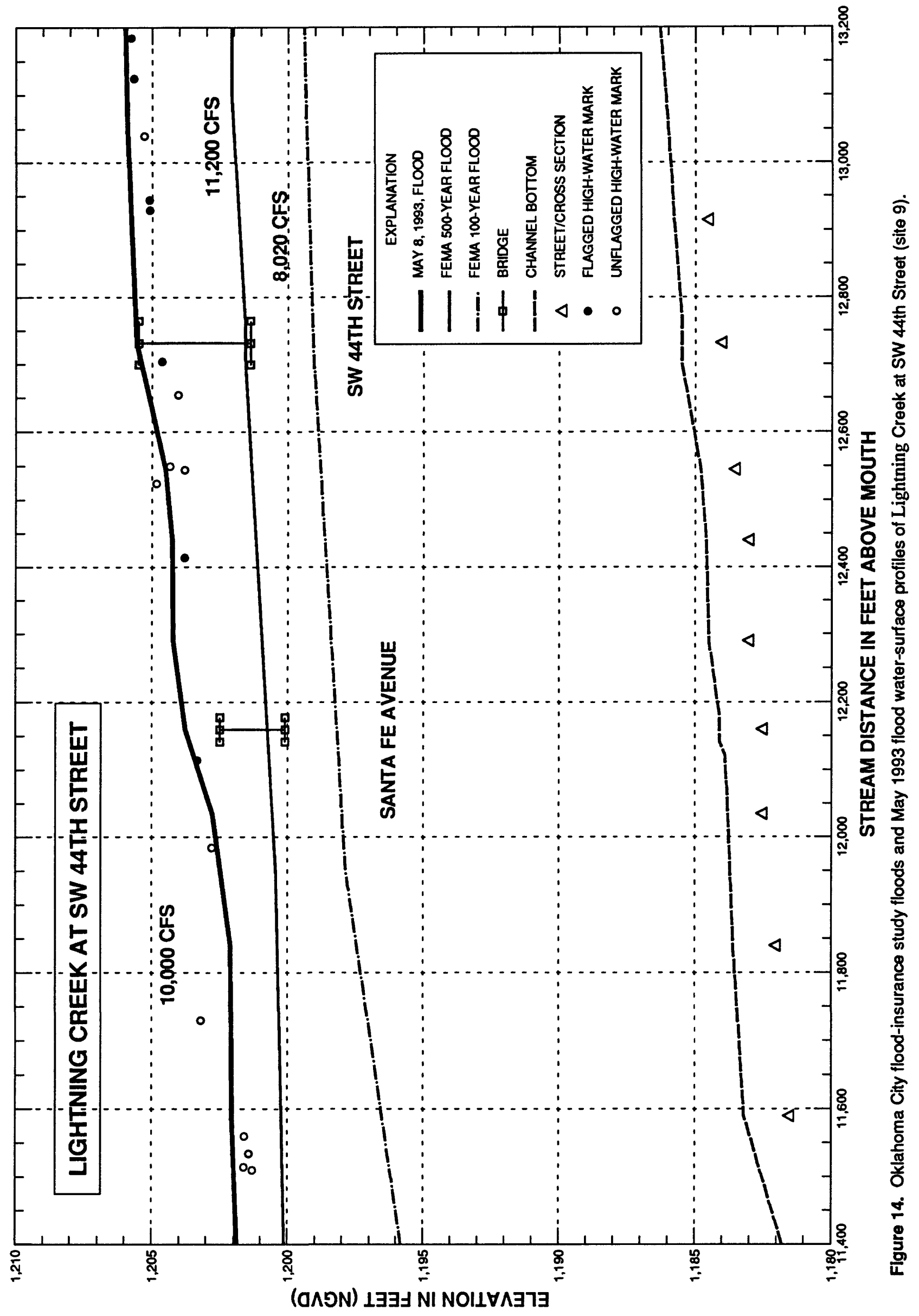




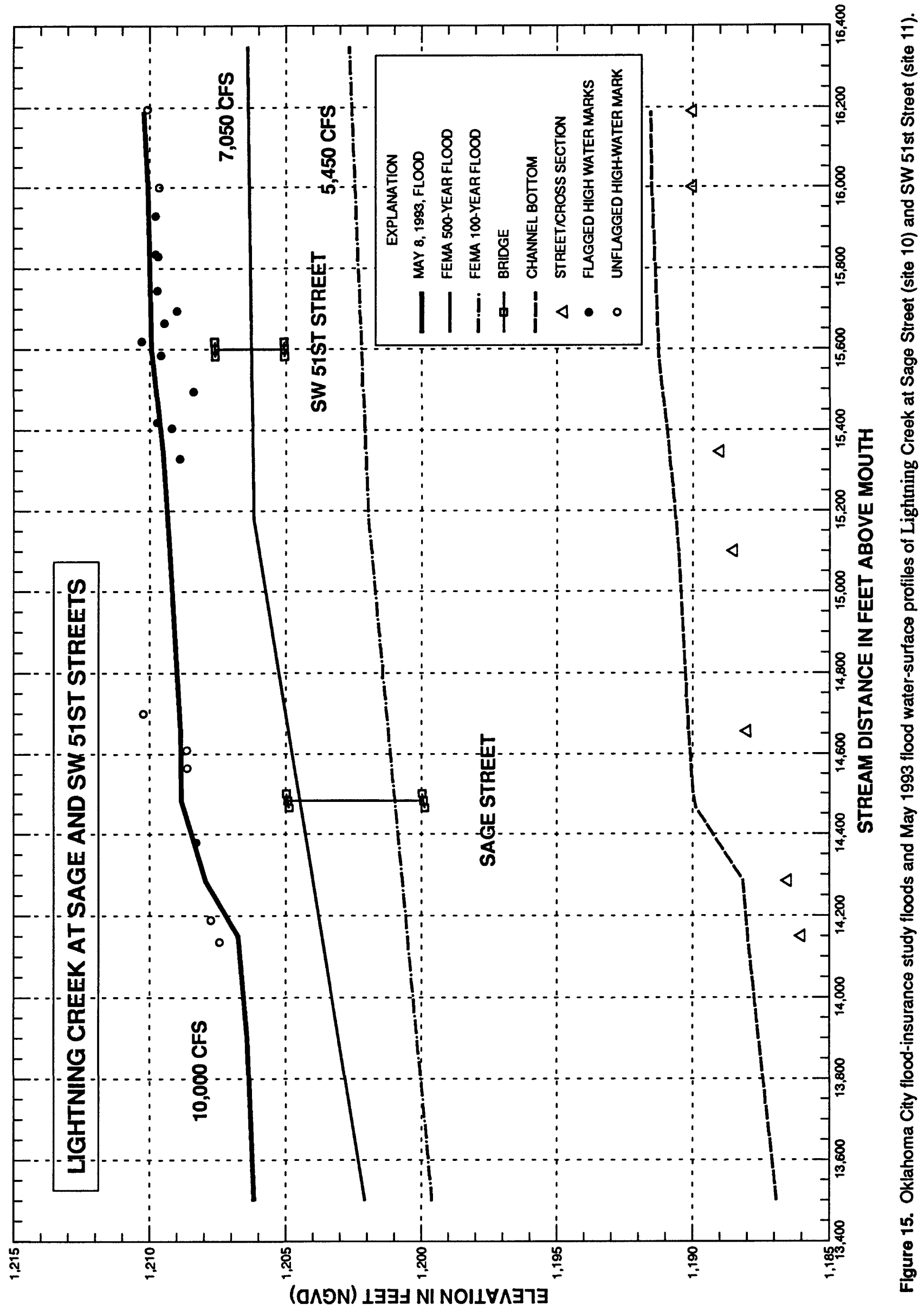


a short period of time, close to 100-percent runoff due to ground surfaces being essentially impervious, and the city streets acting as efficient conveyances to the main channel.

\section{SELECTED REFERENCES}

Bailey, J.F., and Ray, H.A., 1966, Definition of stage-discharge relation in natural channels by step-backwater analysis: U.S. Geological Survey Water Supply Paper 1869-A, $24 \mathrm{p}$.

Benson, M.A., and Dalrymple, Tate, 1967, General field and office procedures for indirect measurements: U.S. Geological Survey Techniques of Water-Resources Investigations, Book3, Chapter A1, 30 p.

Bodhaine, G.L., 1968, Measurement of peak discharge at culverts by indirect methods: U.S. Geological Survey Techniques of Water-Resources Investigations, Book3, Chapter A3, $60 \mathrm{p}$.

Bergman, D.L., and Tortorelli, R.L., 1988, Flood of May 2627, 1984, in Tulsa, Oklahoma: U.S. Geological Survey Hydrologic Investigations Atlas HA-707, scale: $1: 96,000,1: 48,000,1$ sheet.

Bingham, R.H., Bergman, D.L., and Thomas, W.O., 1974, Flood of October 1973 in Enid and vicinity, north-central Oklahoma: U.S. Geological Survey WaterResources Investigations 27-74, scale: 1:250,000, $1: 126,720,2$ sheets.

Brown, D.D., 1993, May 8, 1993, flooding: The City of Oklahoma City --City Manager's Report No. 4064, 5p.

Carter, R.W., and Davidian, Jacob, 1968, General procedure for gaging streams: U.S. Geological Survey Techniques of Water-Resources Investigations, Book3, Chapter A6, $13 \mathrm{p}$.

Crippen, J. R., and Bue, C.D., 1977, Maximum floodflows in the conterminous United States: U.S. Geological Survey Water Supply Paper 1887, $52 \mathrm{p}$.

Davidian, Jacob, 1984, Computation of water-surface profiles in open channels: U.S. Geological Survey Techniques of Water-Resources Investigations, Book3, Chapter A15, $48 \mathrm{p}$.

Druse, S.A., 1982, Verification of step-backwater computations on ephemeral streams in northeastern Wyoming:
U.S. Geological Survey Water-Supply Paper 2199, 12

p.

English, Paul, 1993, 4 counties declared eligible for U.S. aid: Daily Oklahoman, Oklahoma City, Okla., v. 102, no. 133, May 13, 1993, p. 7.

Federal Emergency Management Agency, 1990, Flood Insurance Study, City of Oklahoma City, Oklahoma, Community Number 405378, 178 p.

Hershfield, D.M., 1961, Rainfall frequency atlas of the United States for durations from 30 minutes to 24 hours and return periods from 1 to 100 years: U.S. Weather Bureau Technical Paper 40,115 p.

Leopold, L.B., 1968, Hydrology for urban land planning - A guidebook on the hydrologic effects of urban land use: U.S. Geological Survey Circular 554, 18 p.

National Oceanic and Atmospheric Administration, 1993, Hourly precipitation data, Oklahoma, May 1993, vol. 43, no. 5 , p. 9.

Sauer, V.B., 1974, Flood characteristics of Oklahoma streams: U.S. Geological Survey Water-Resources Investigations 52-73, $301 \mathrm{p}$.

Shearman, J.O., 1990, User's manual for WSPRO--a computer model for water surface profile computations (Hydraulic Computer Program HY-7): U.S. Federal Highway Administration Publication No. FHWA-IP89-027, $177 \mathrm{p}$.

Thomas, W.O., Jr., and Corley, R.K., 1977, Techniques for estimating flood discharges for Oklahoma streams: U.S. Geological Survey Water-Resources Investigations 77 $54,170 \mathrm{p}$.

Tortorelli, R.L., Huntzinger, T.L., Bergman, D.L., and Patneaude, A.L., Jr., 1983, Urban flood analysis in Oklahoma City, Oklahoma: U.S. Geological Survey OpenFile Report 83-26, 94 p.

Tortorelli, R.L., Cooter, E.J., and Schuelein, J.W., 1991, Oklahoma--Floods and droughts, in National water summary 1988-89--Hydrologic events and floods and droughts: U.S. Geological Survey Water Supply Paper 2375, p. 451-458.

U.S. Geological Survey, 1990, Digital elevation models: U.S. Geological Survey National Mapping Program Technical Instructions, Data Users Guide, 51 p.

Zizzo, David, 1993,Victims console each other, exchange stories of flood: Daily Oklahoman, Oklahoma City, Okla., v. 102, no. 131, May 11, 1993, p. 7. 
APPENDICES 


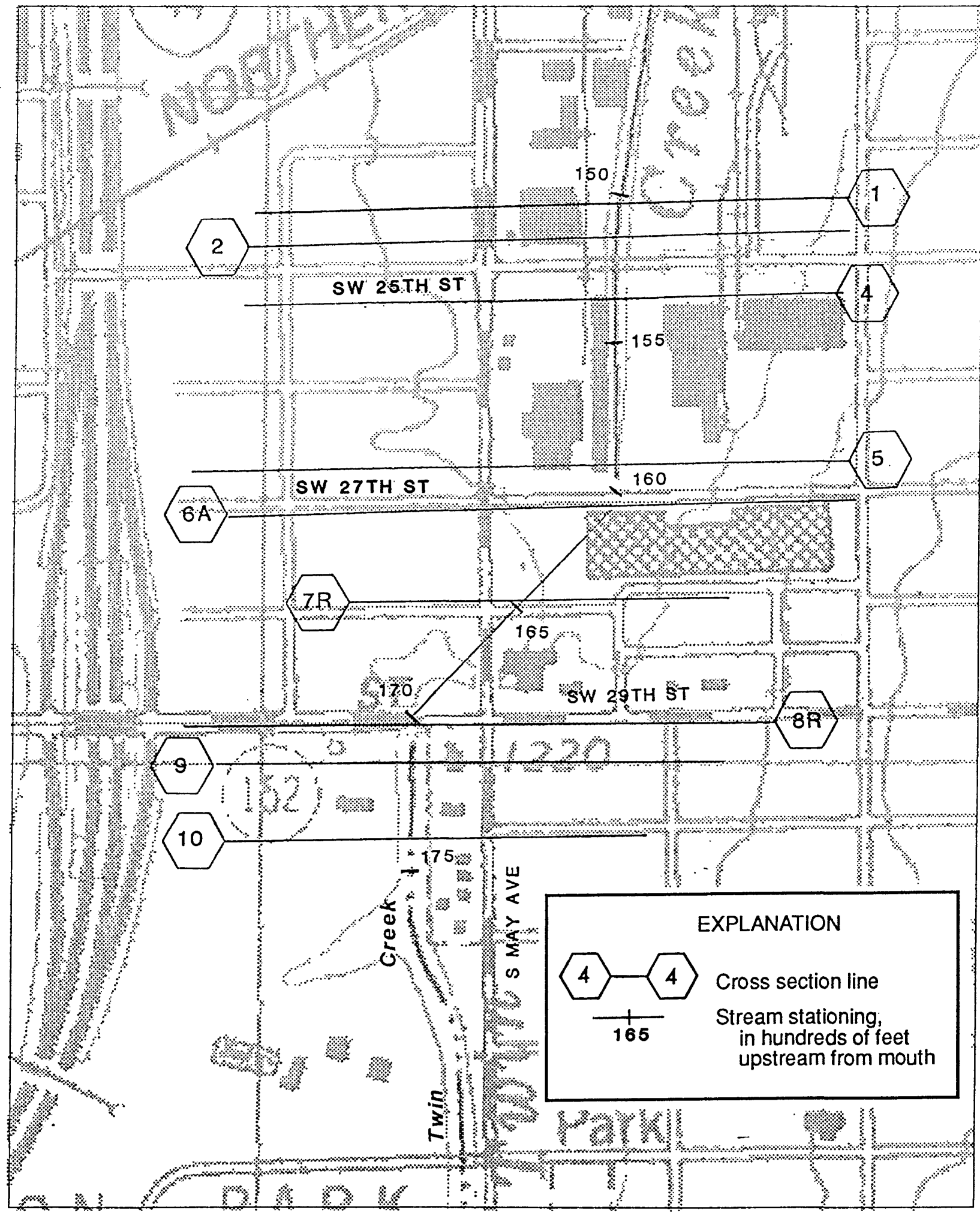

Base from U.S. Geological Survey Digital Raster Graphic, 1:24,000, 1986 Projection: Oklahoma Coordinate System, north zone (Lambert Conformal Conic) 


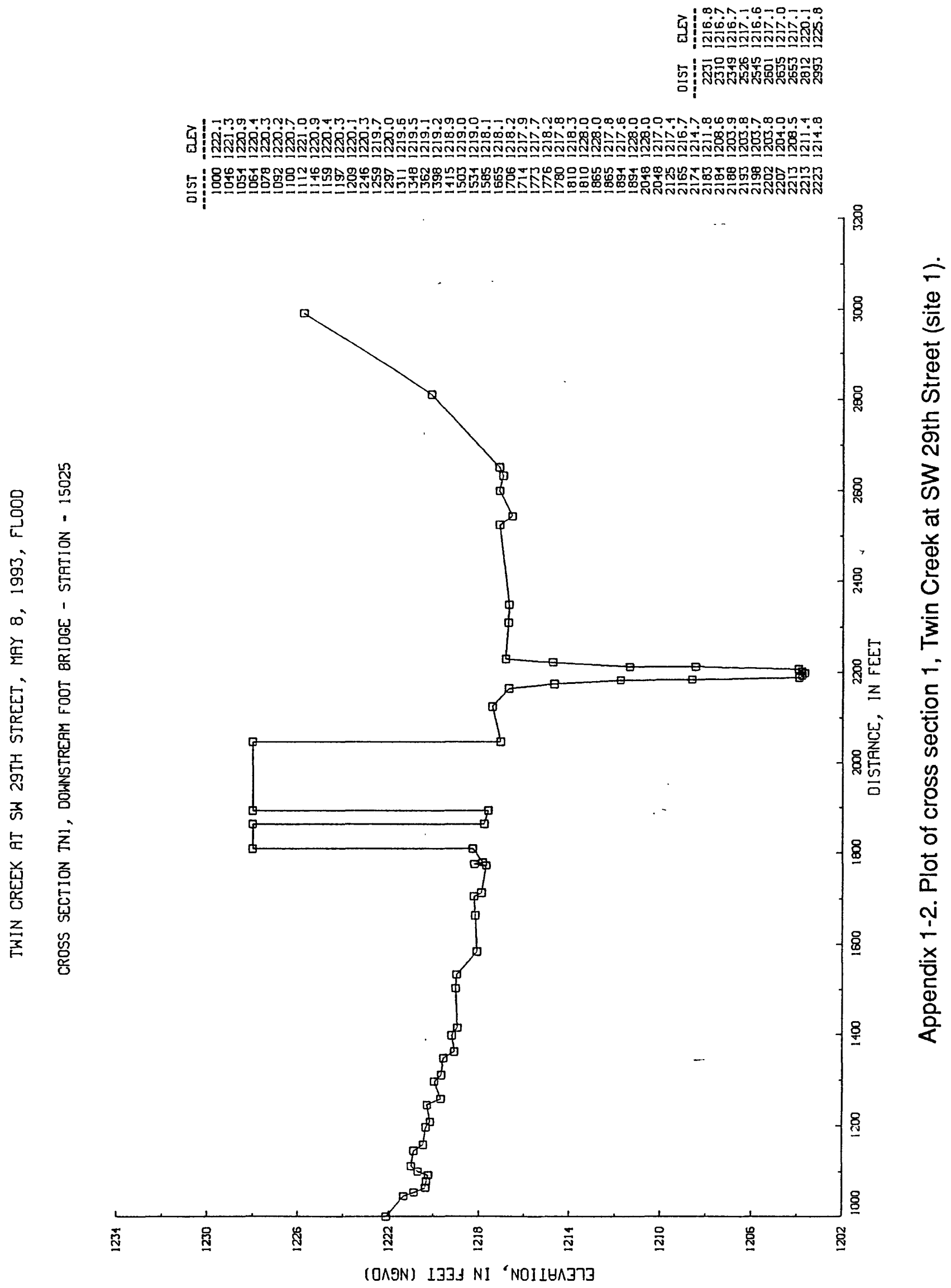




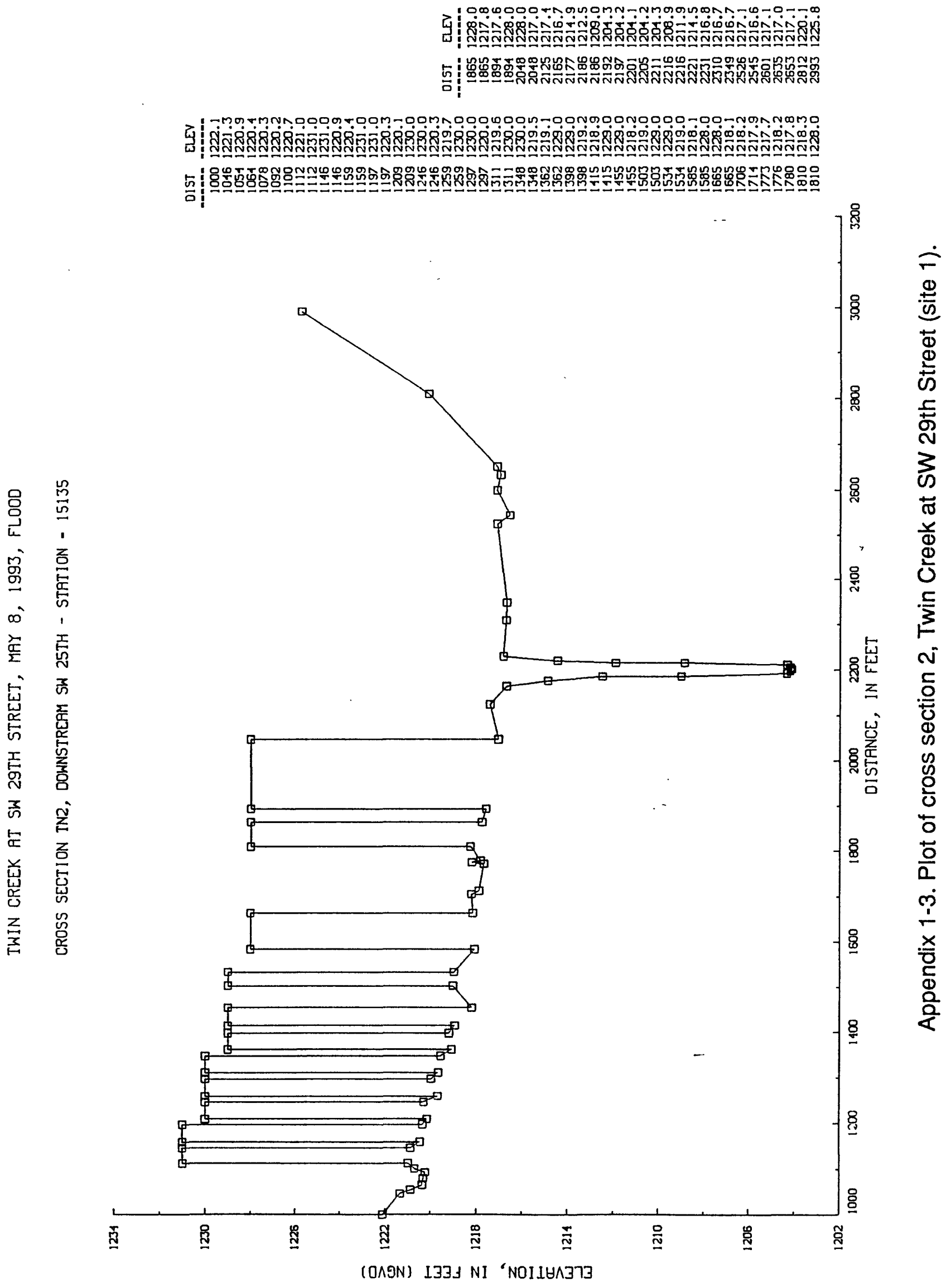




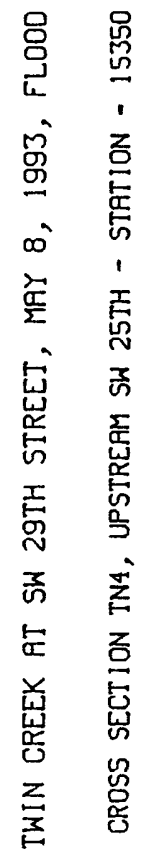

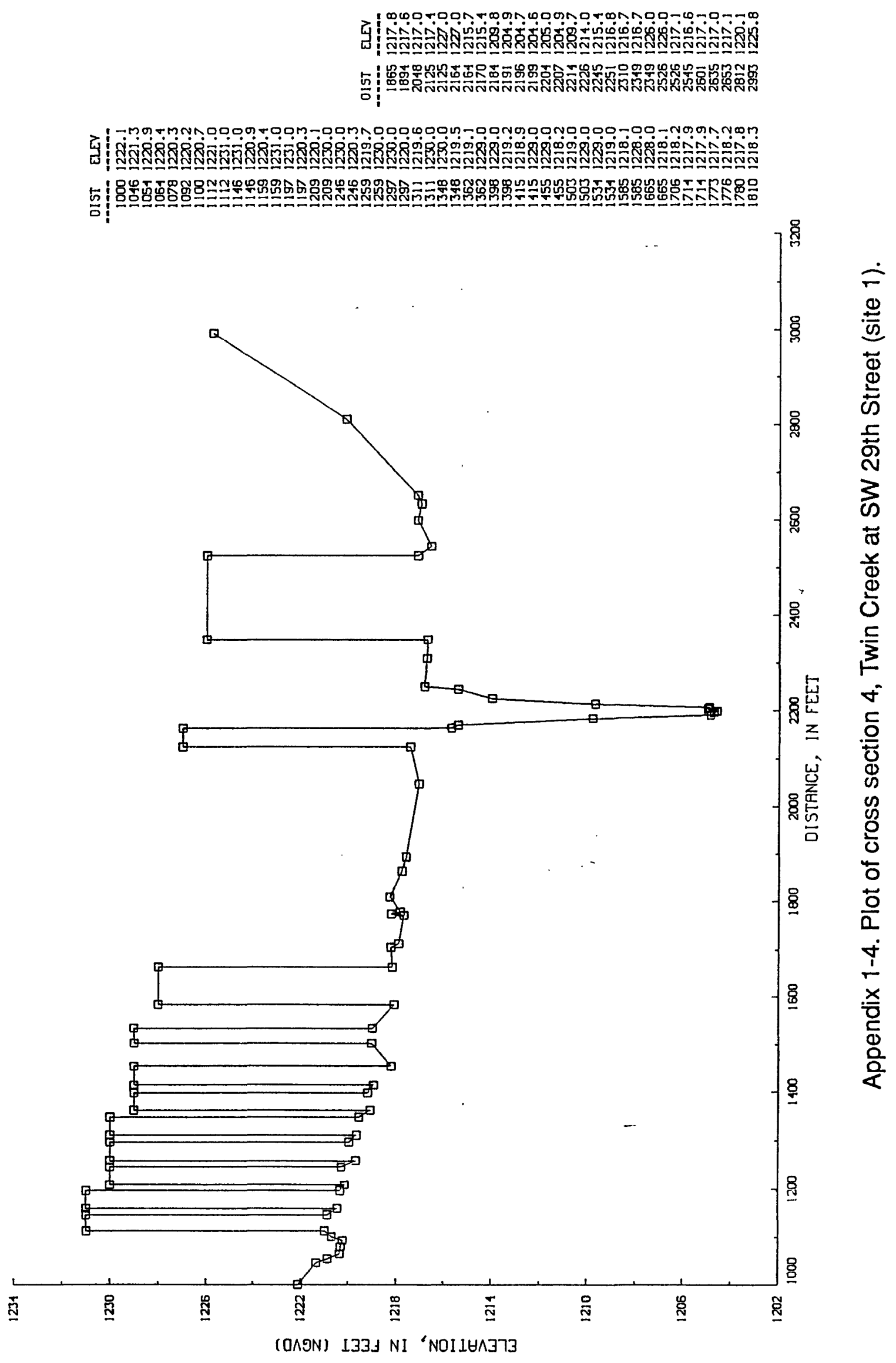


> |

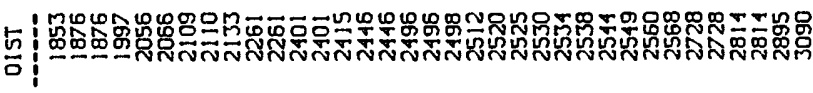

乙

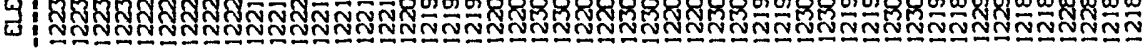

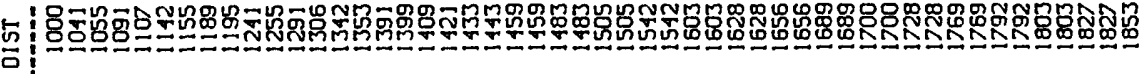

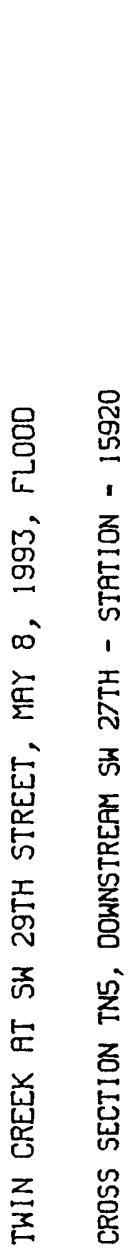

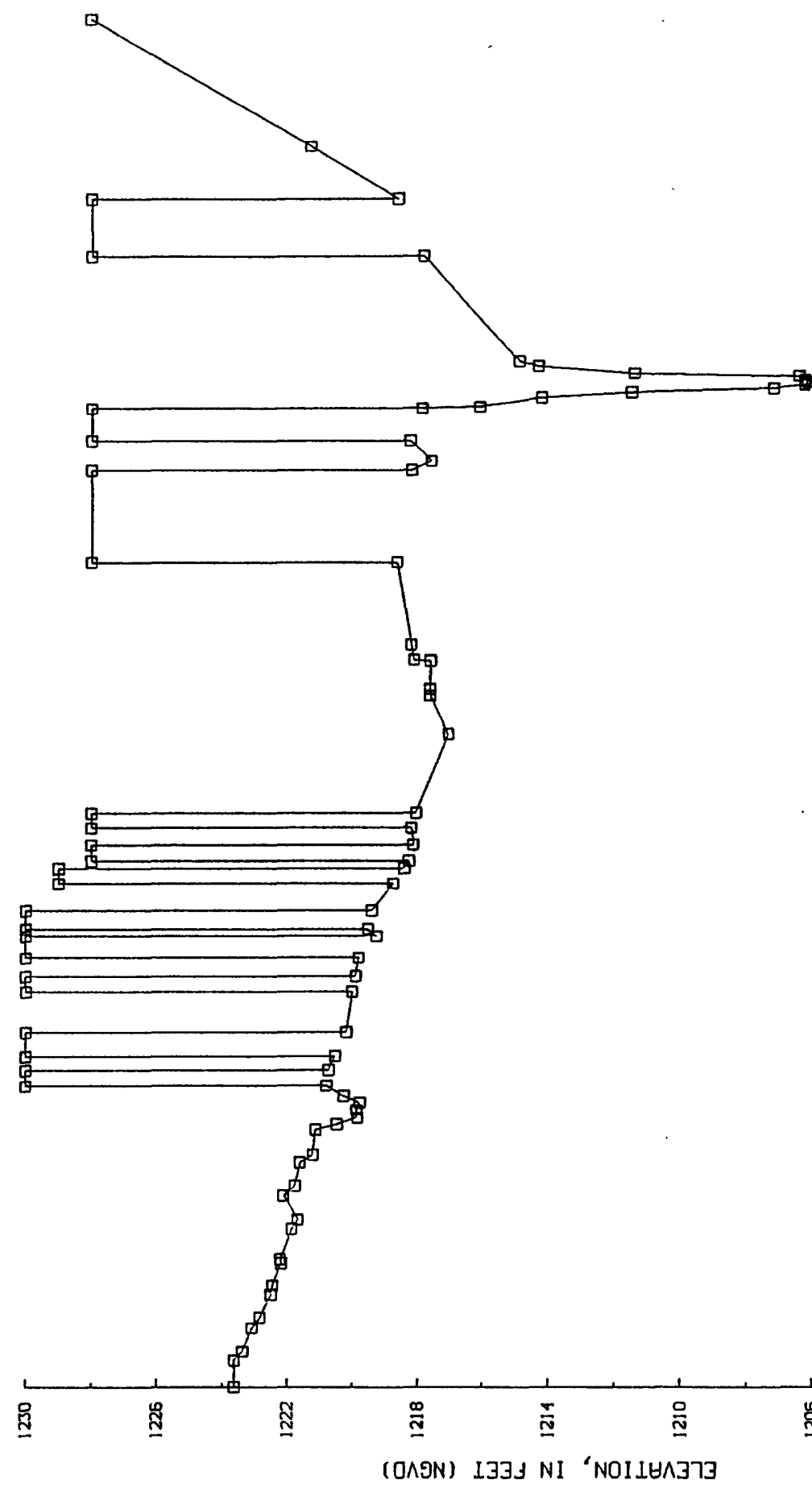




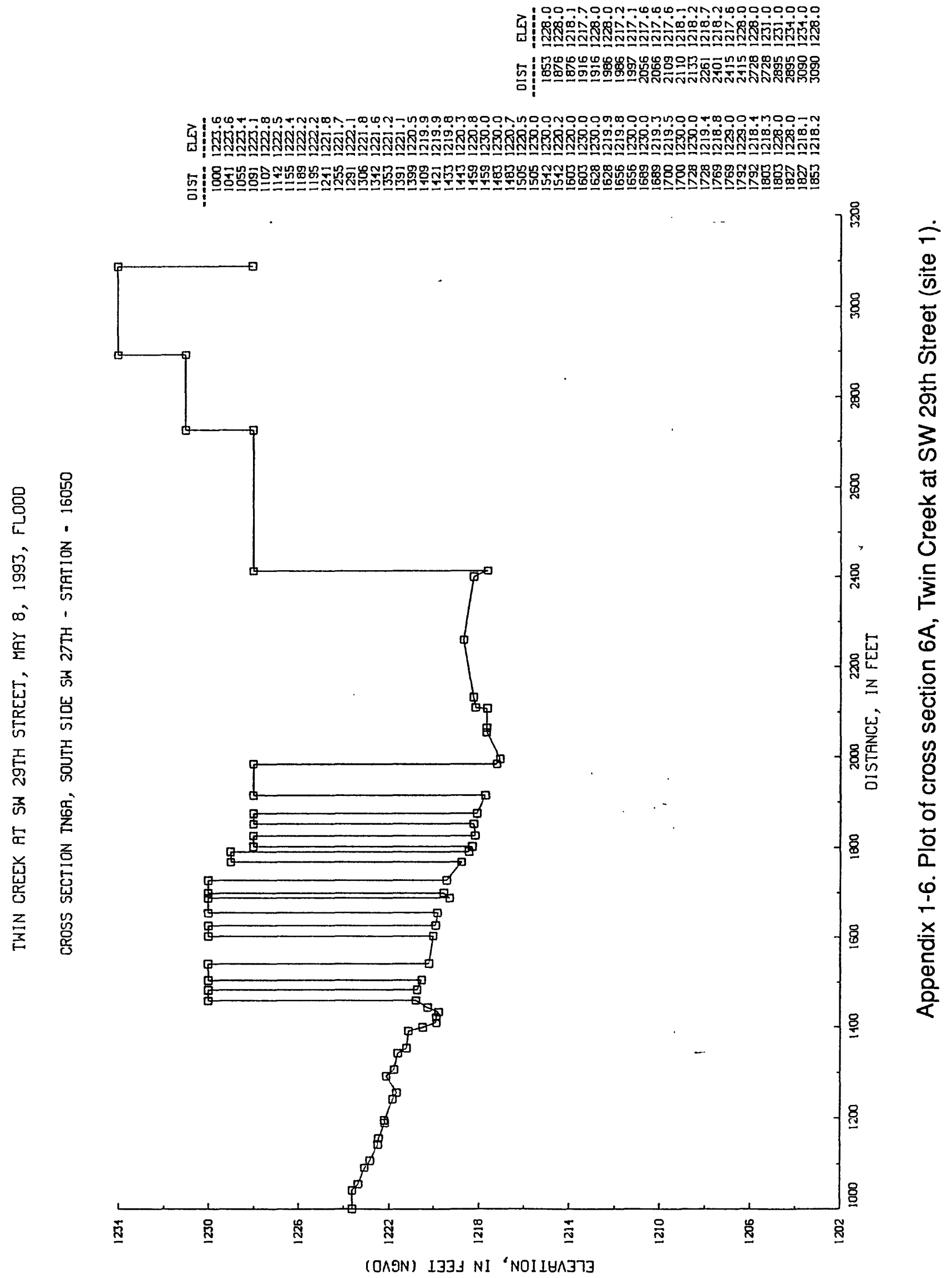




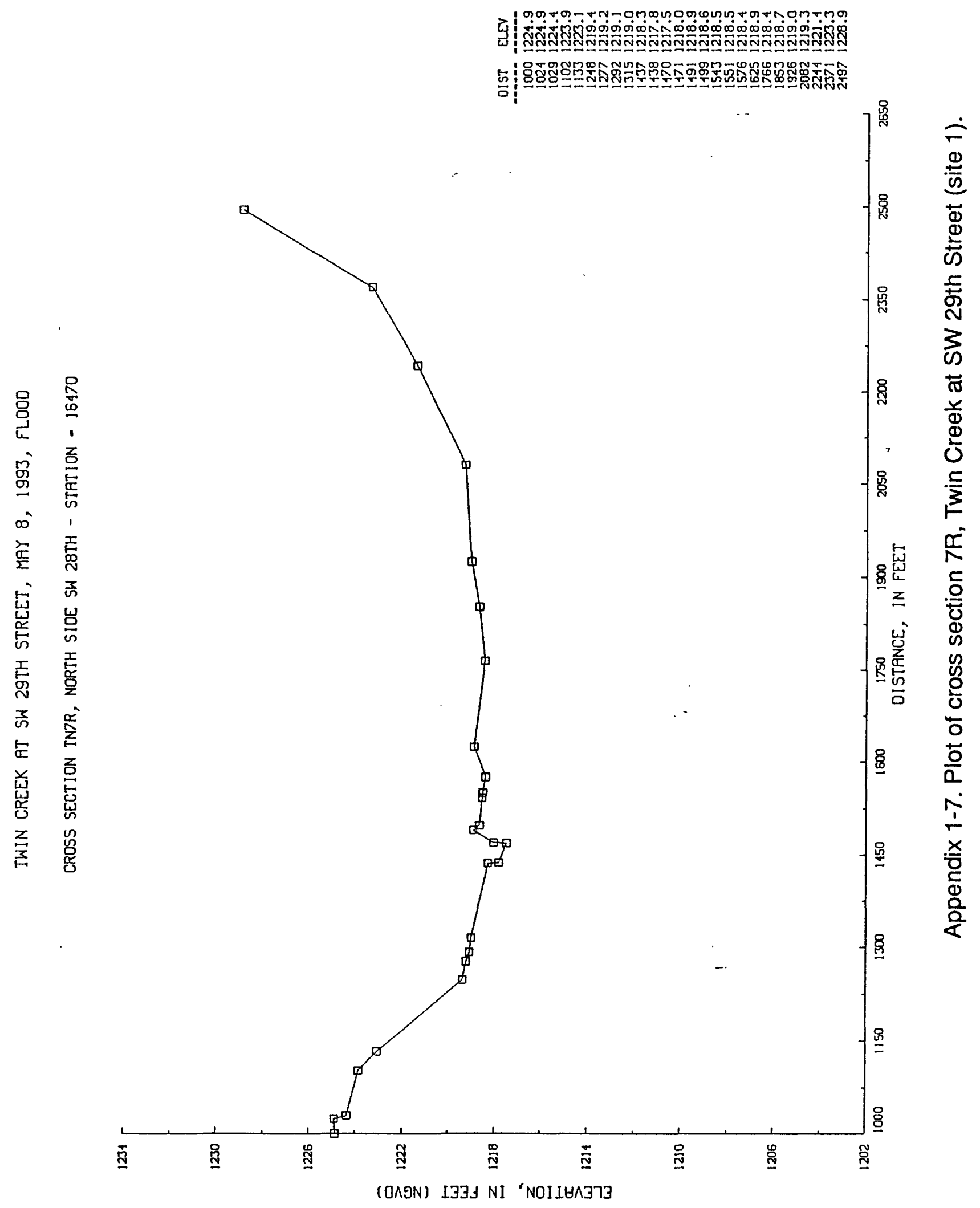




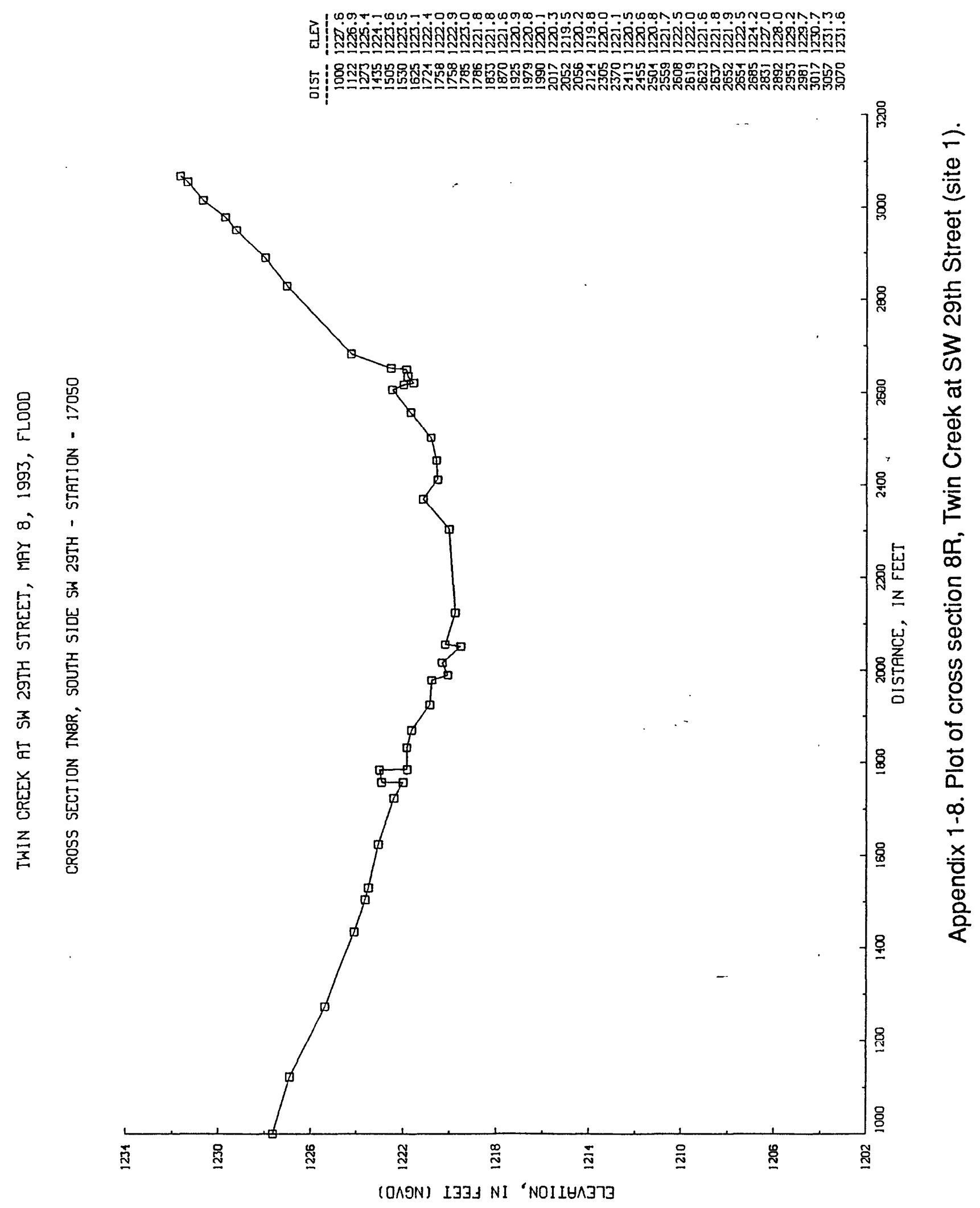




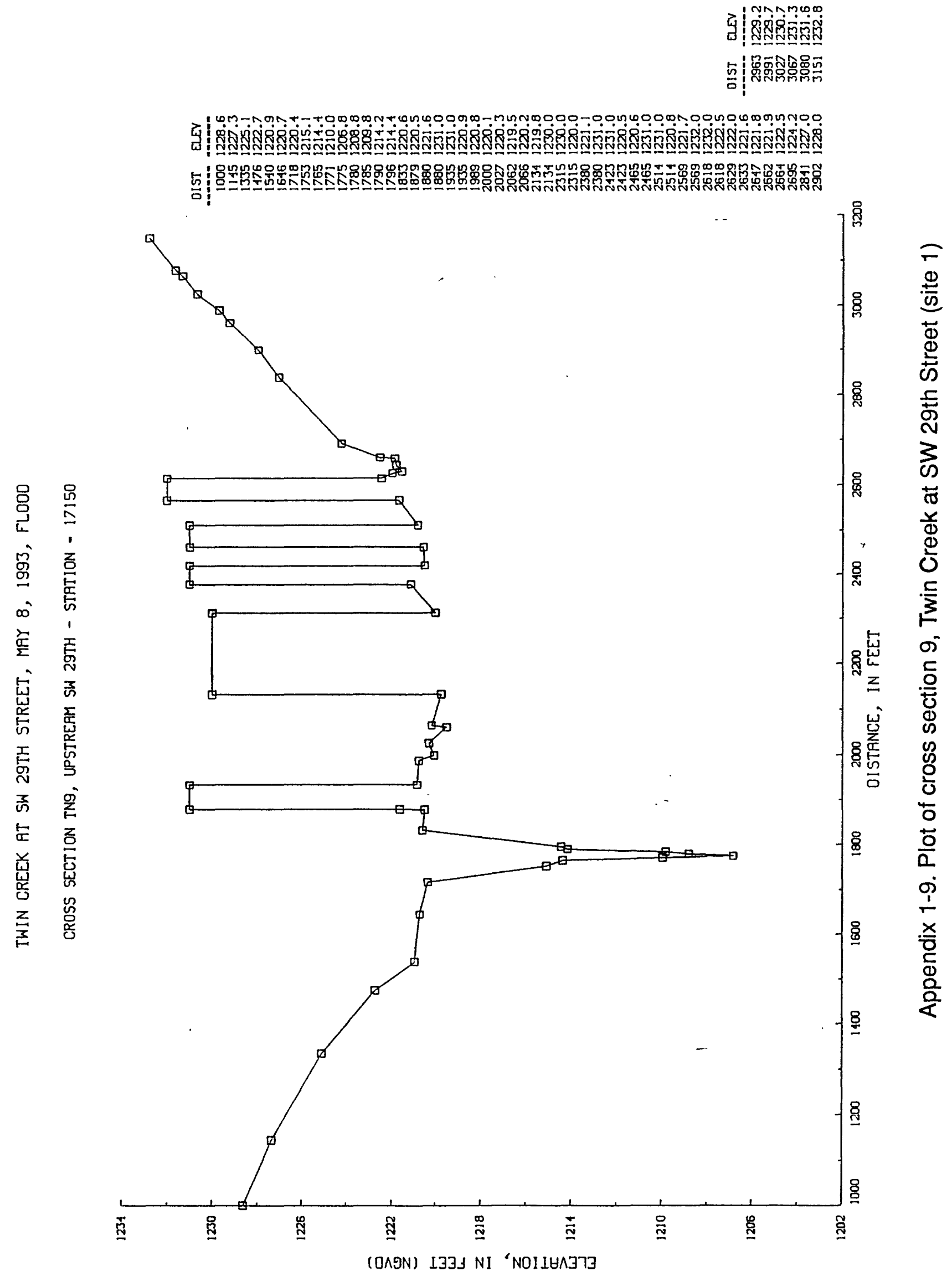



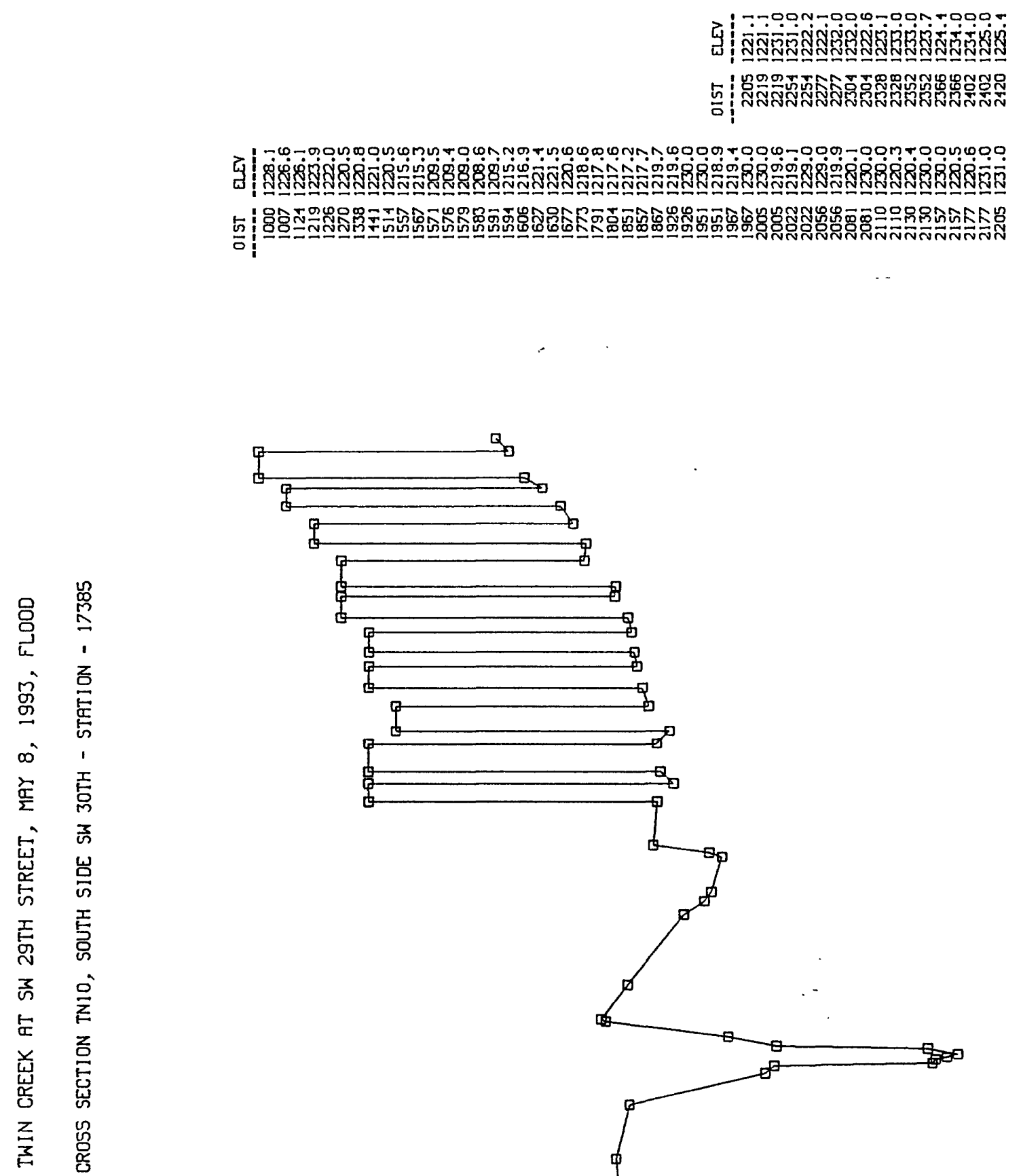

7 -

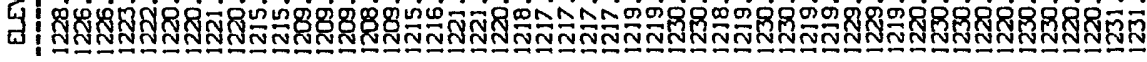

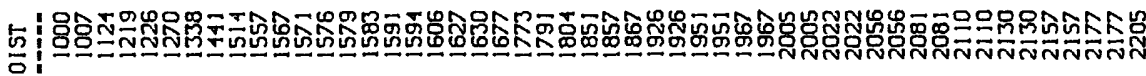

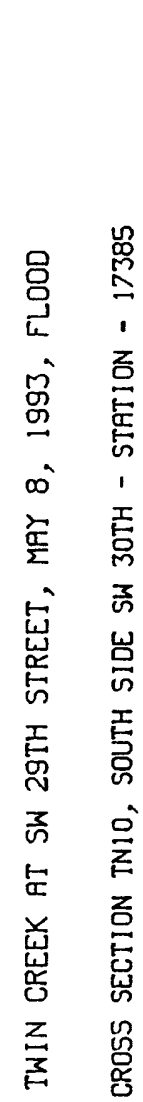

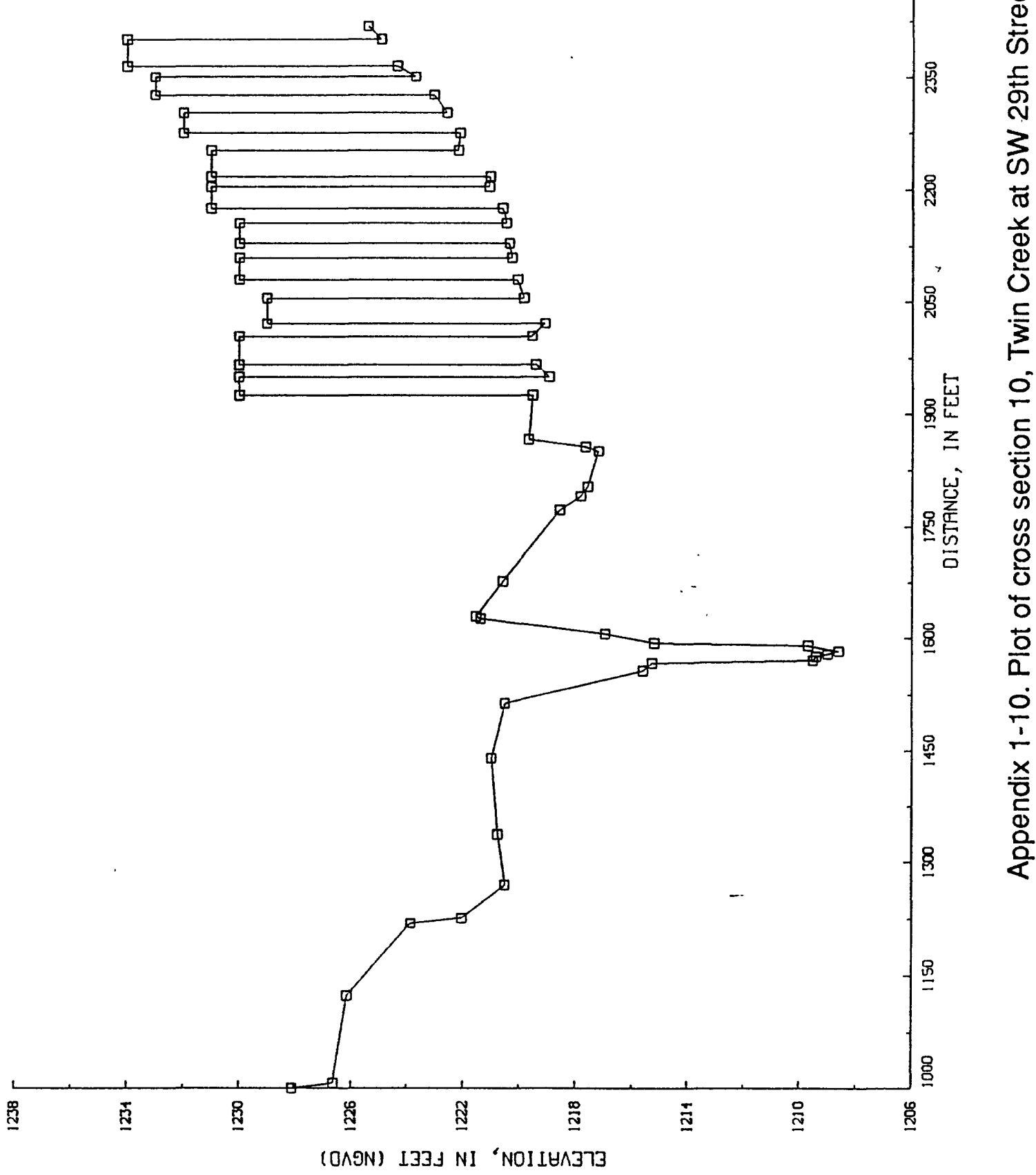




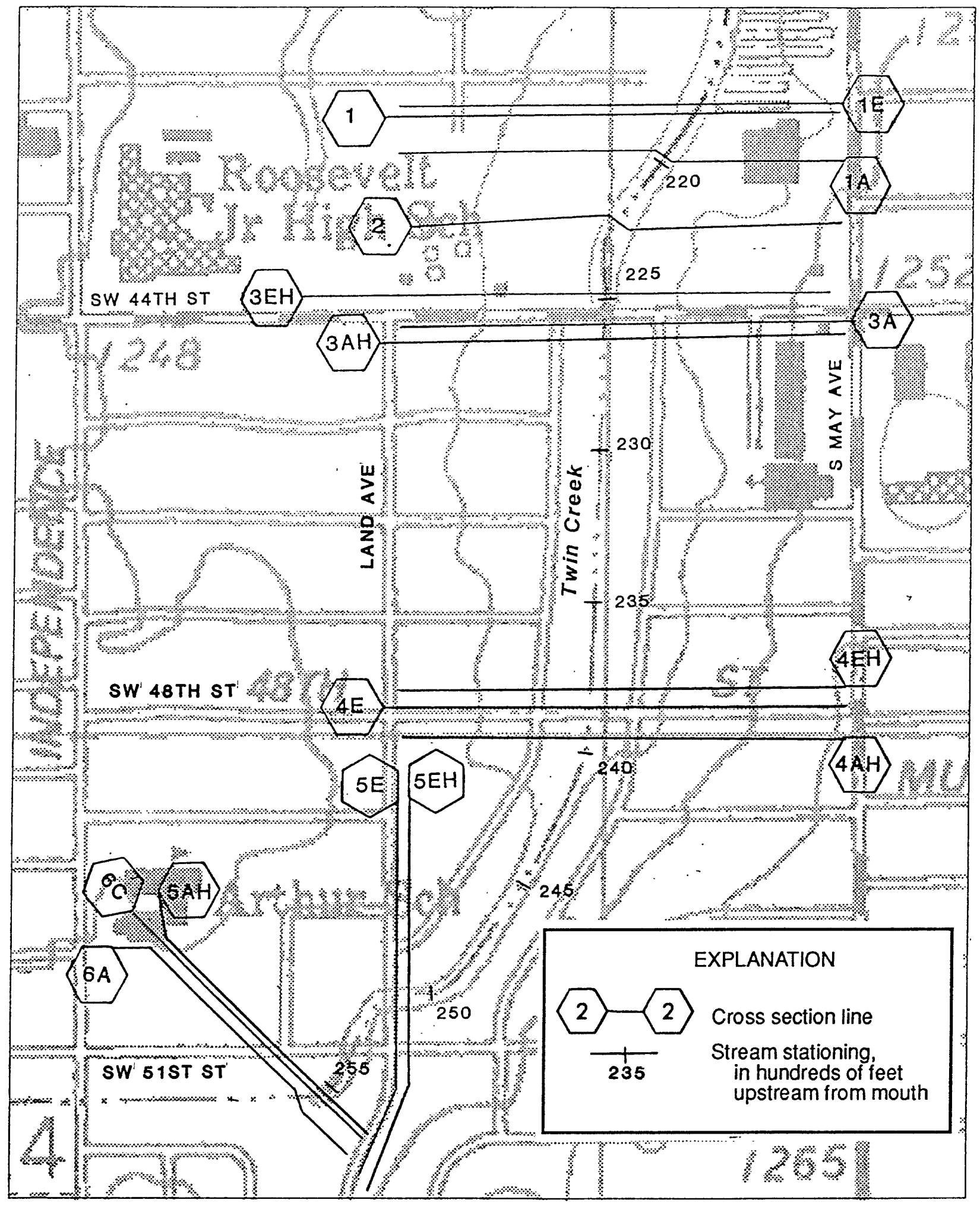

Base from U.S. Geological Survey Digital Raster Graphic, 1:24,000, 1986 Projection: Oklahoma Coordinate System, north zone (Lambert Contormal Conic) 


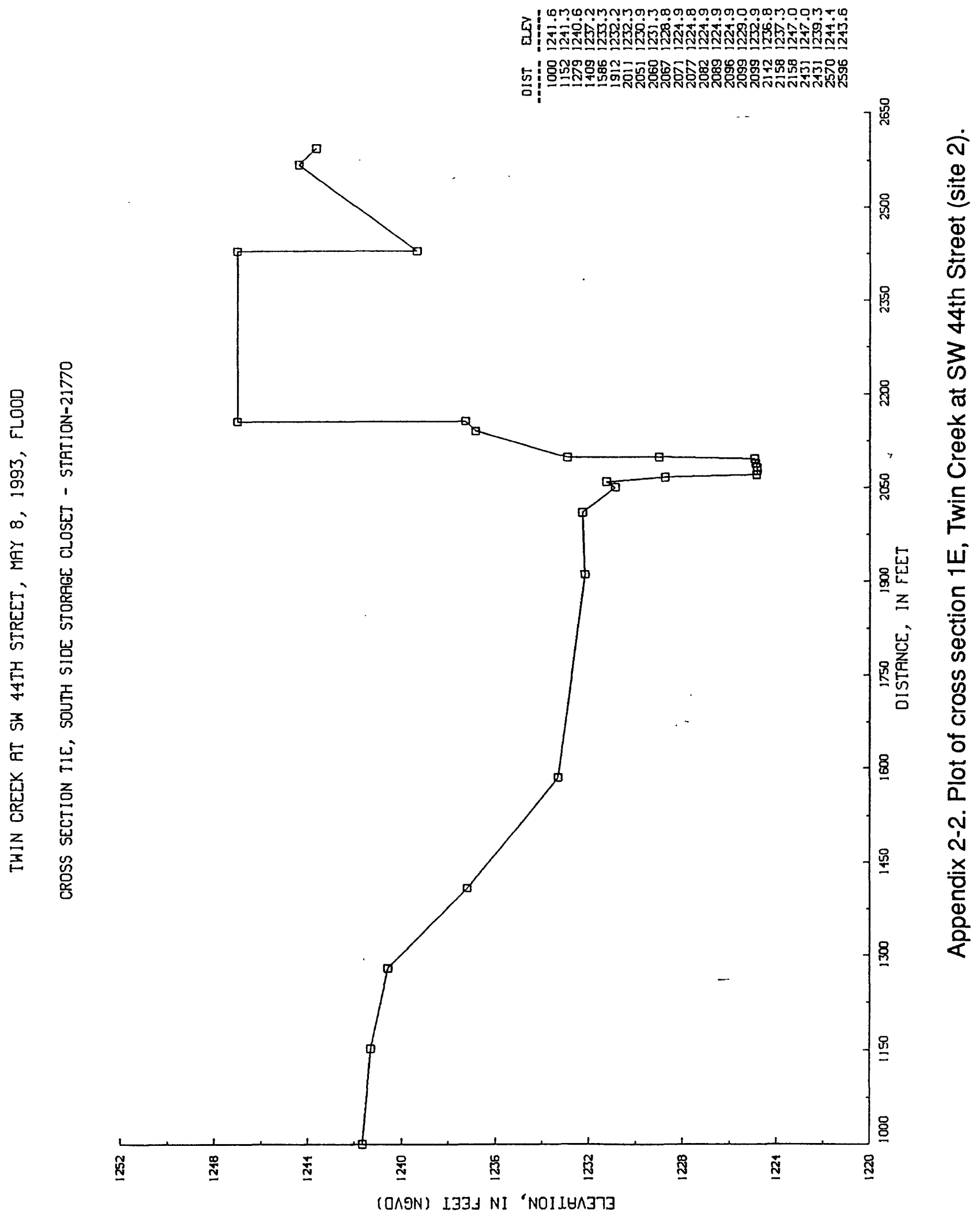




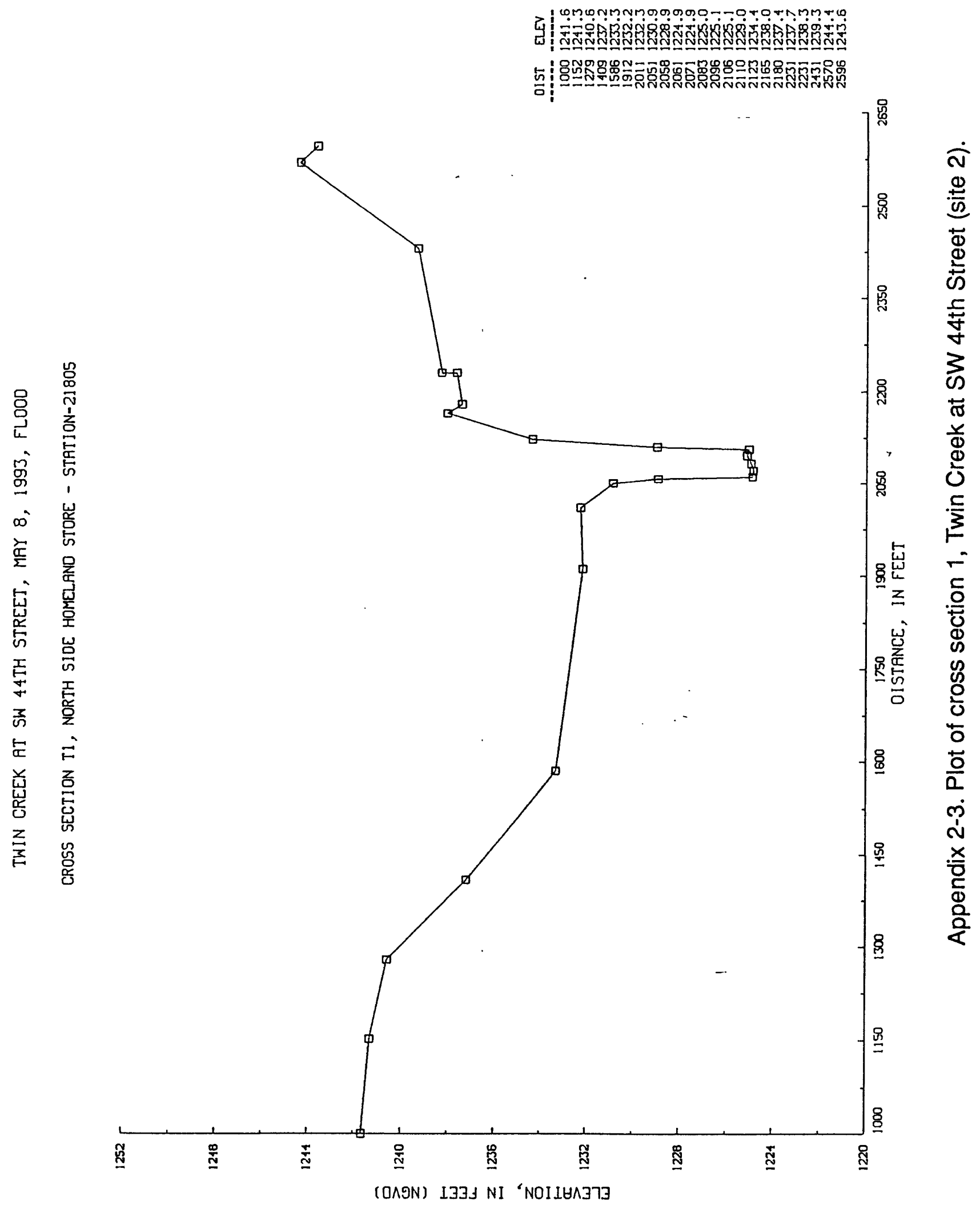




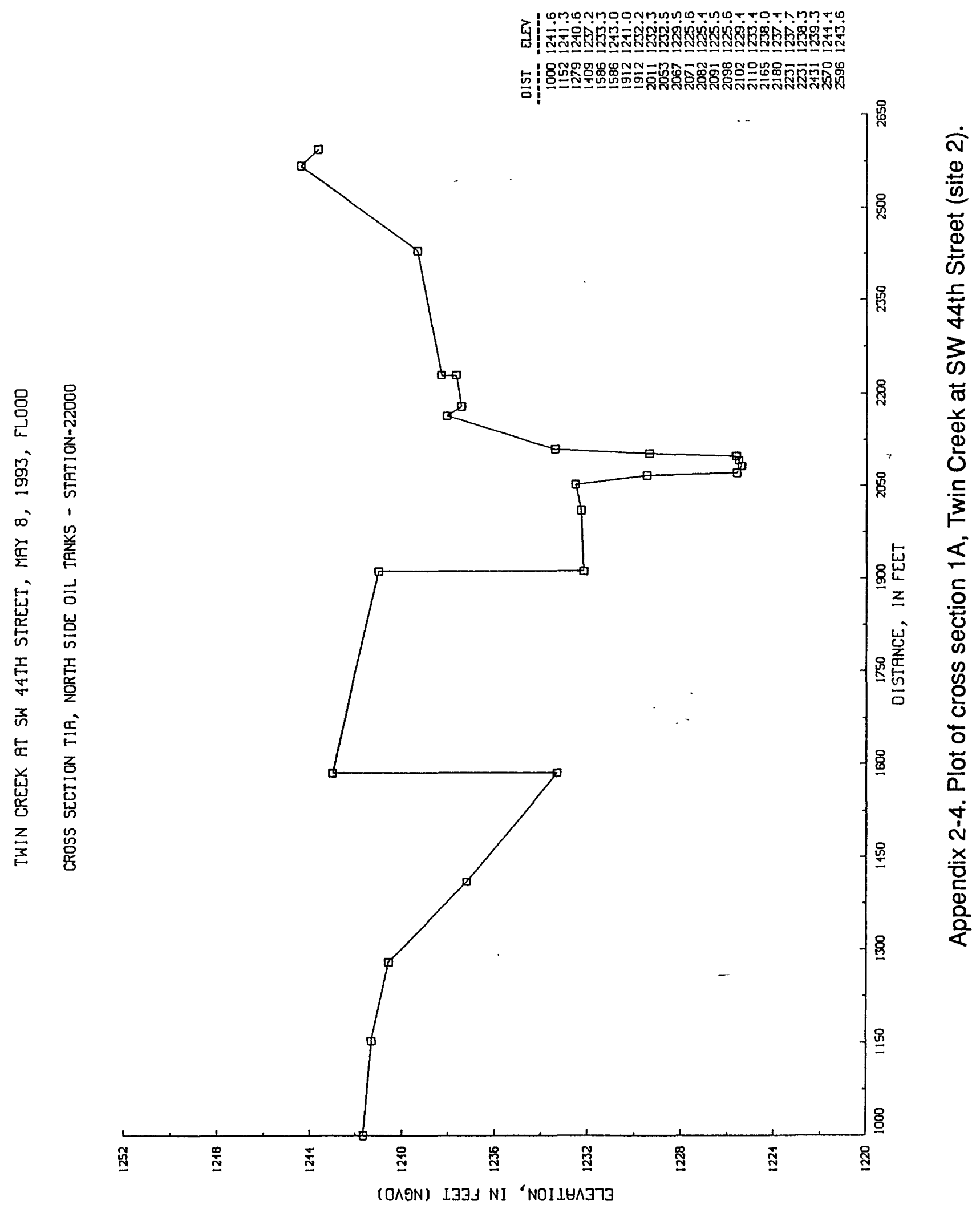




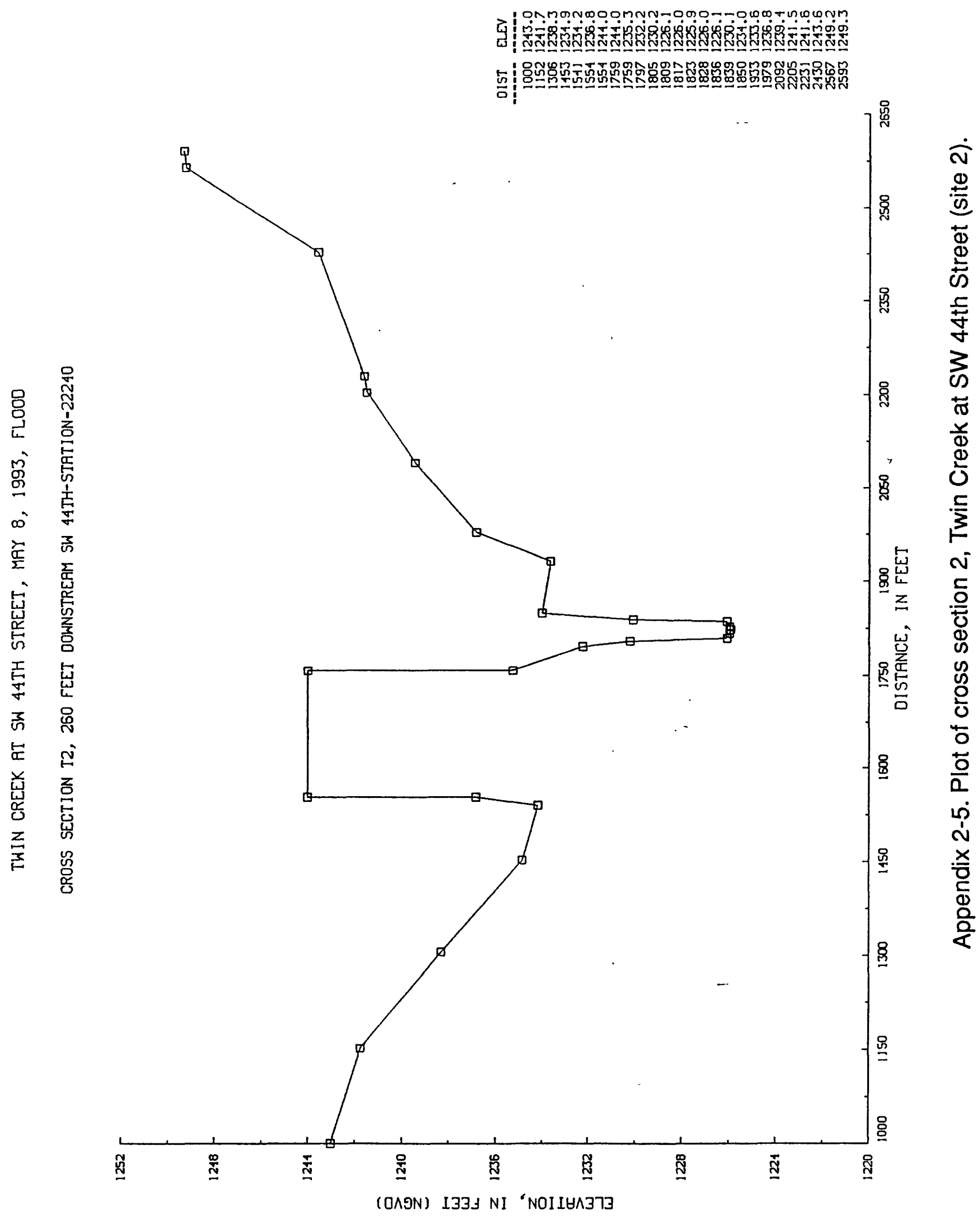




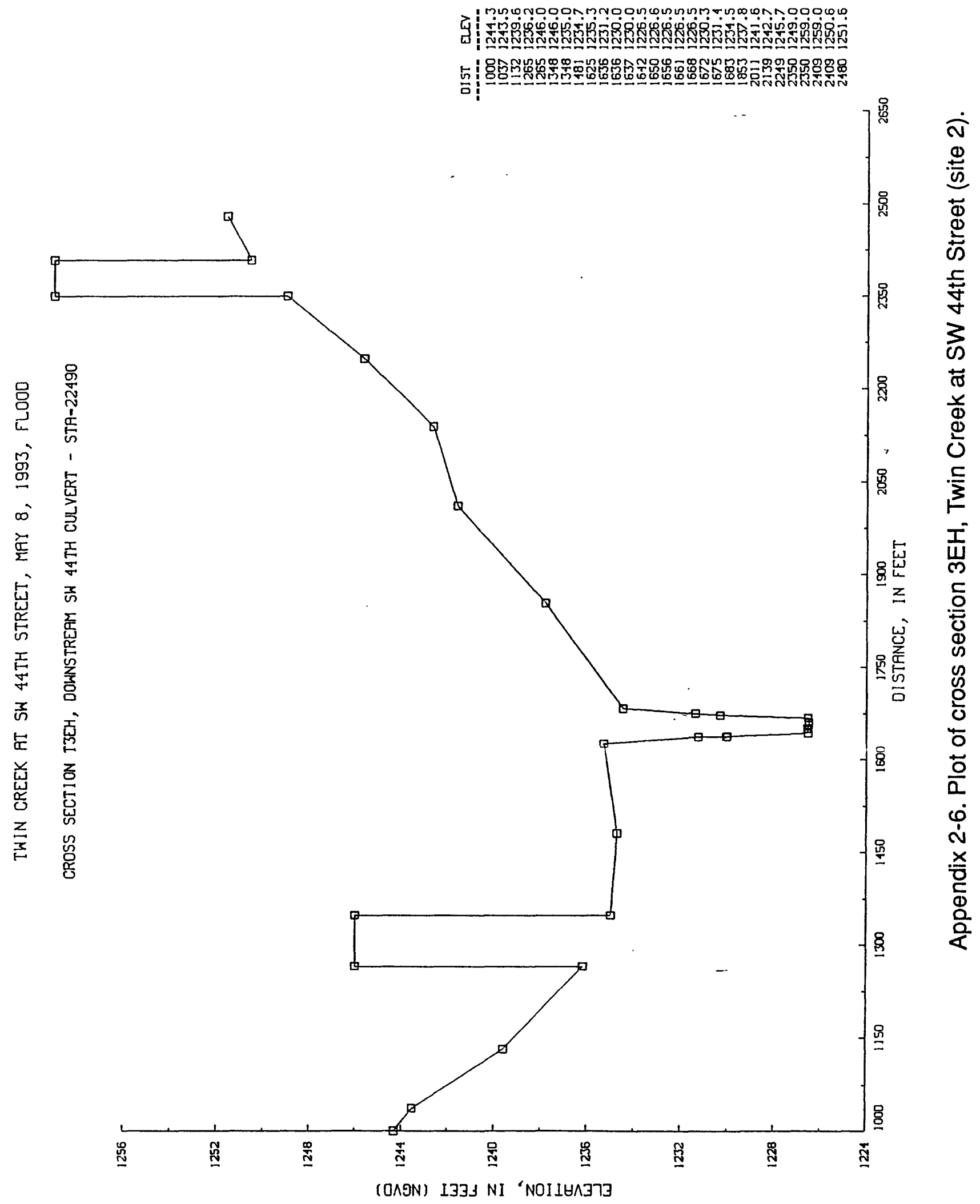




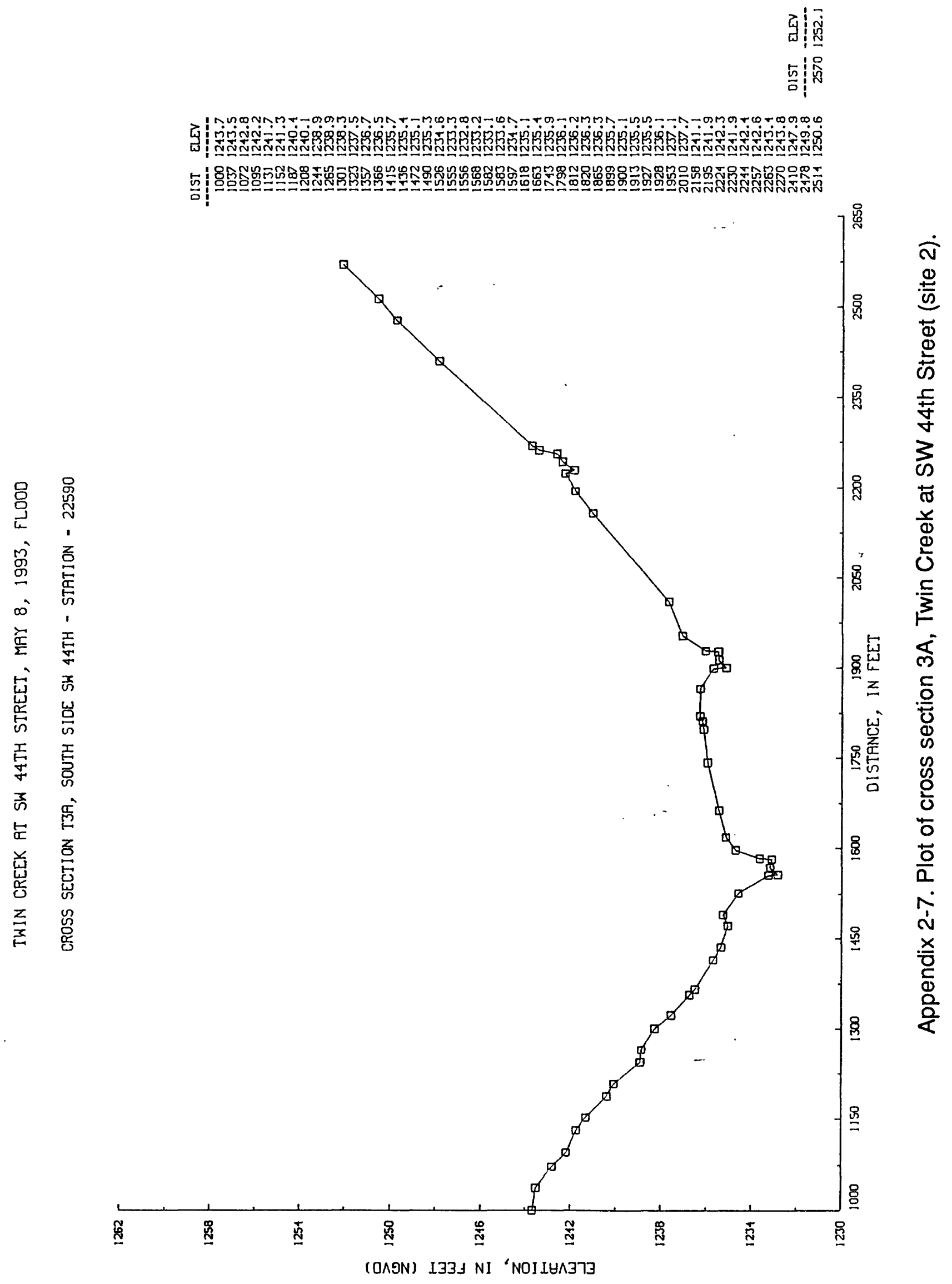




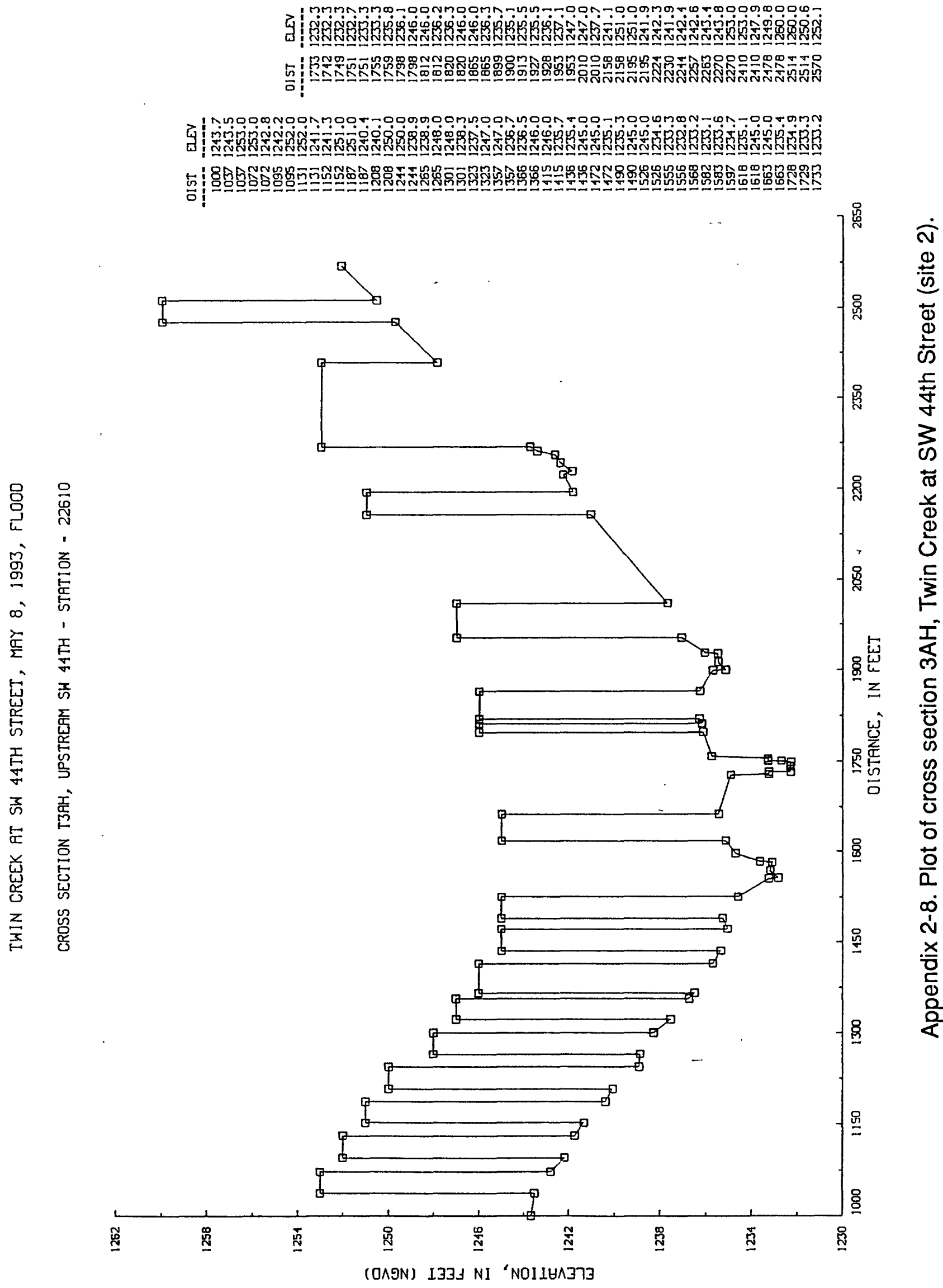




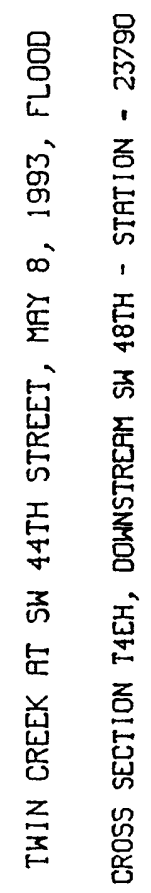

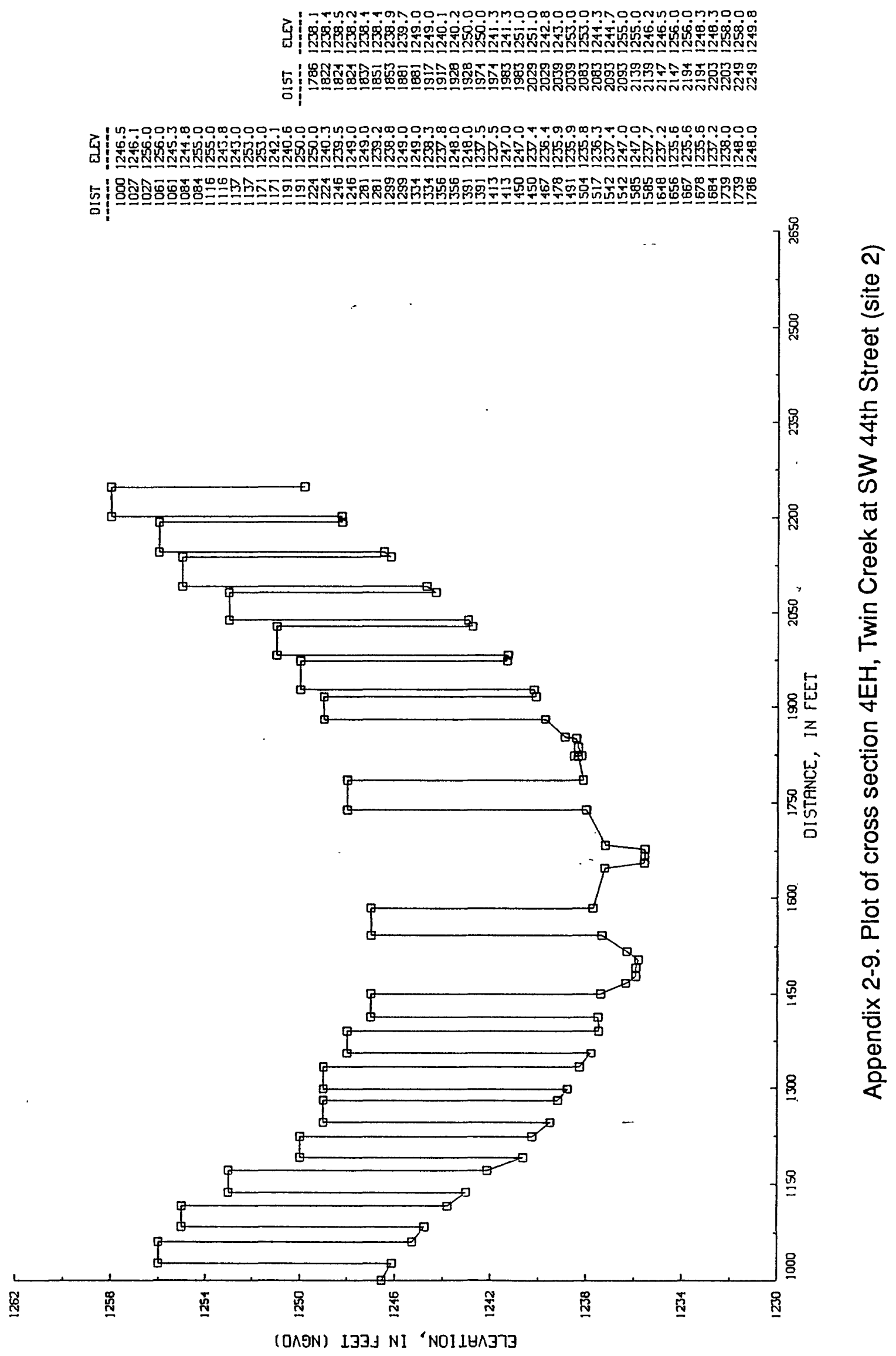




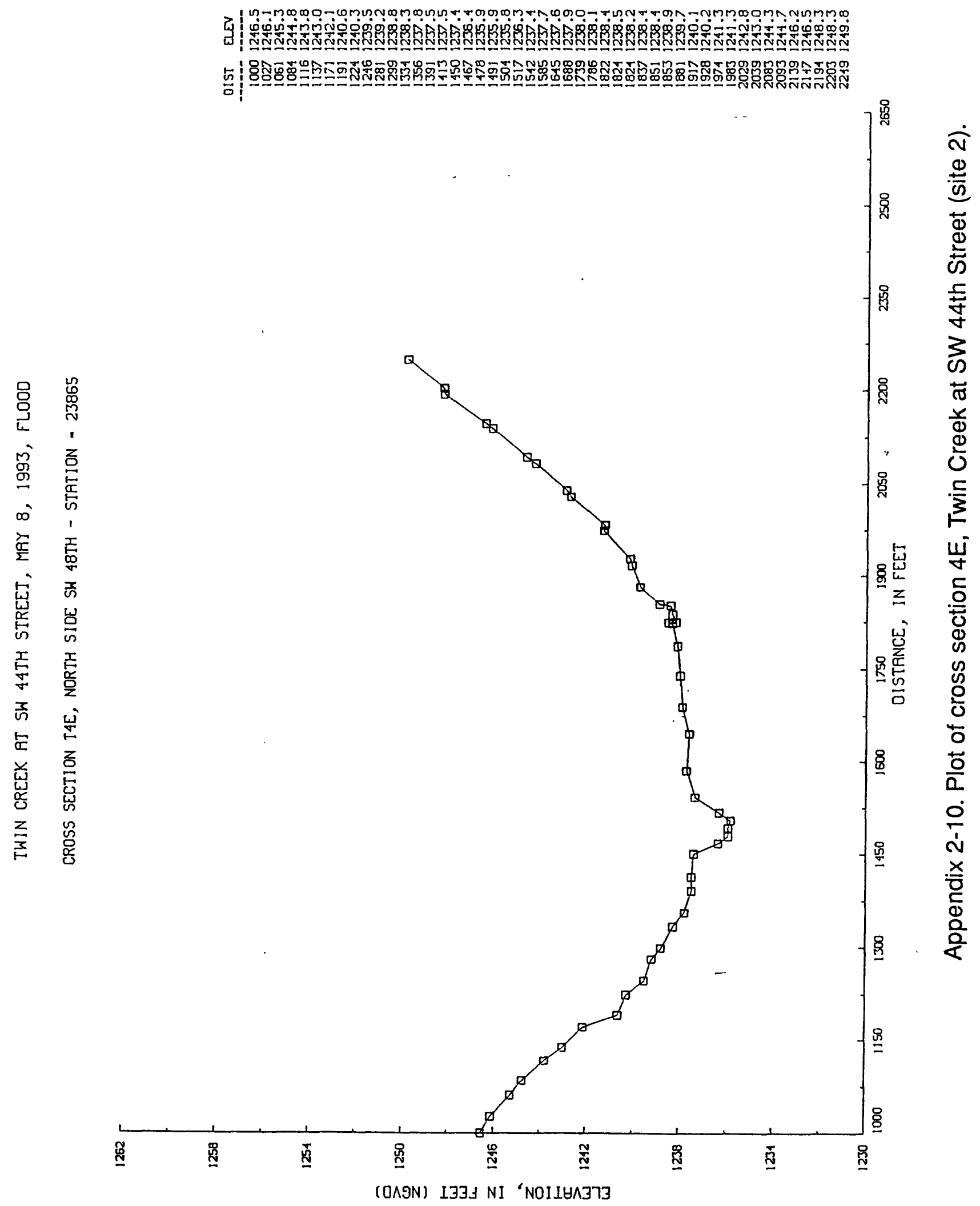



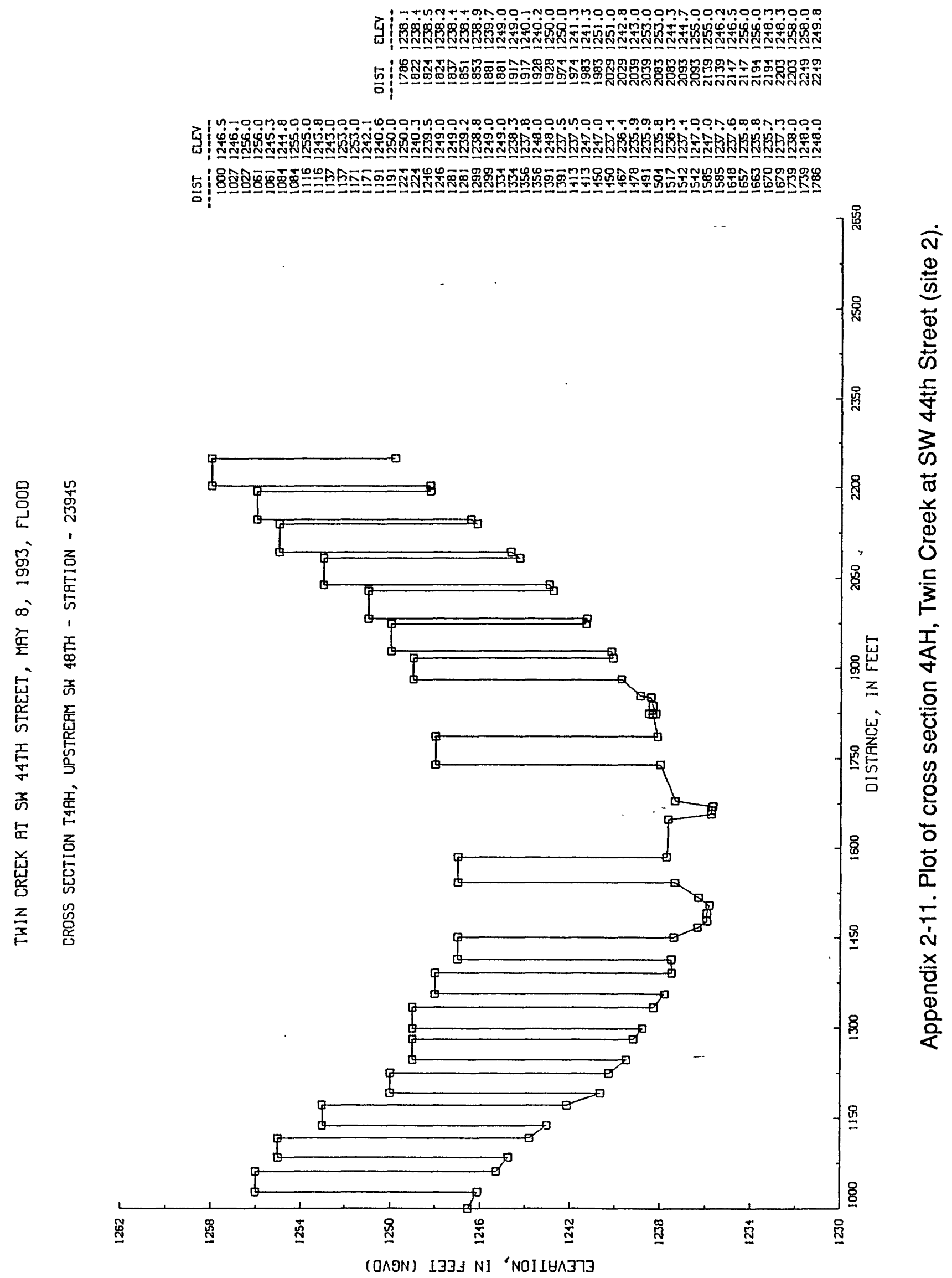

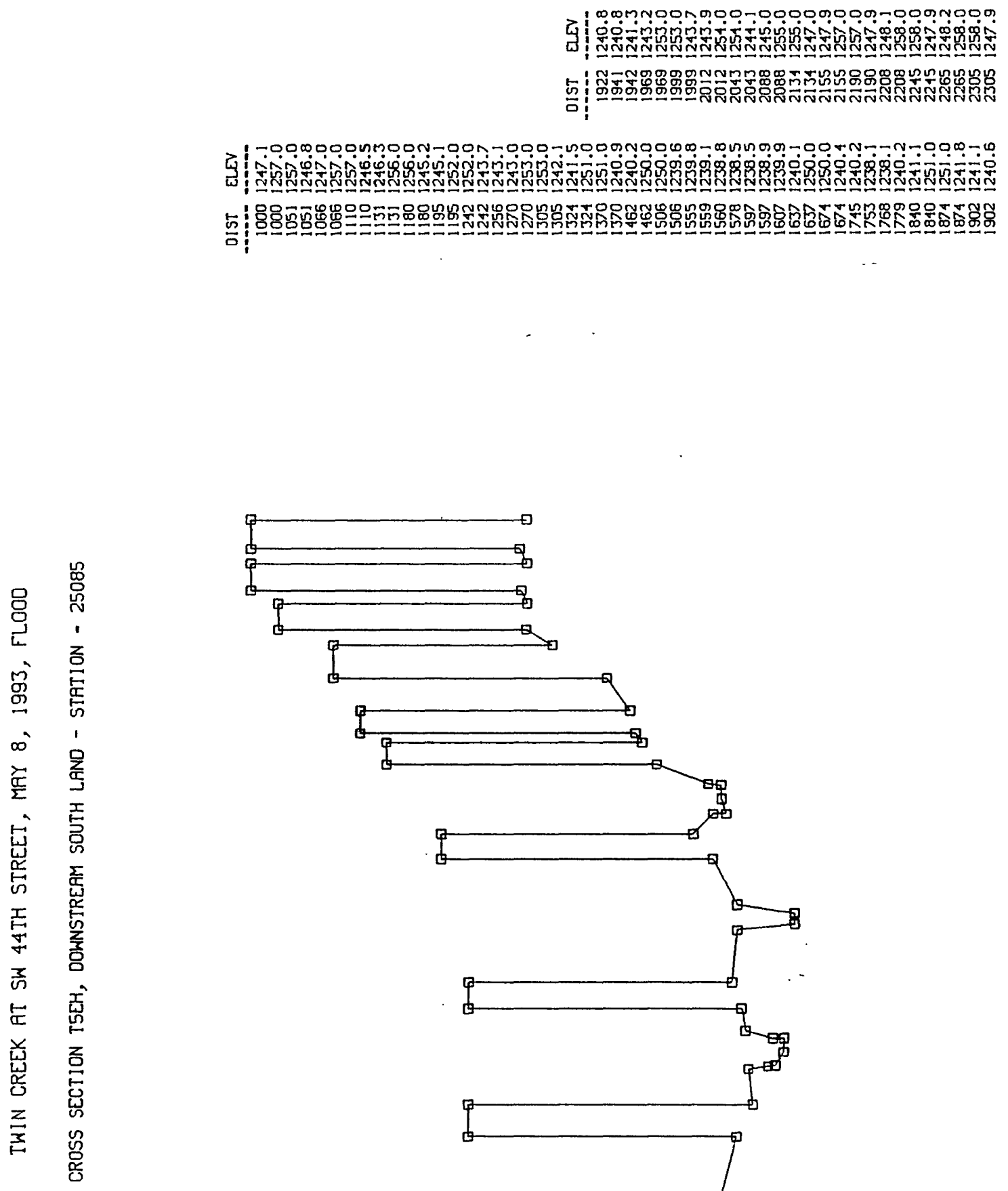

乙)

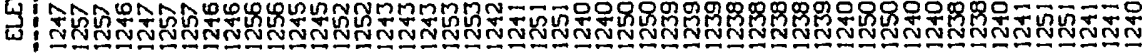

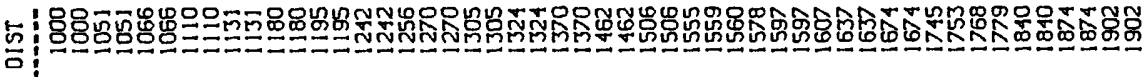

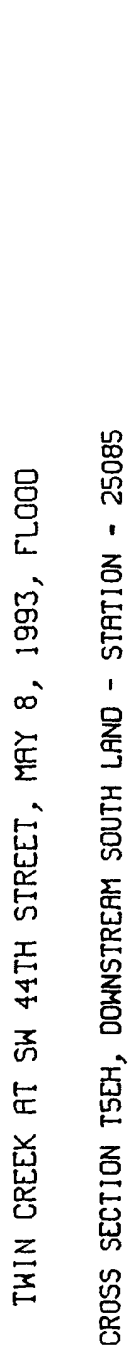

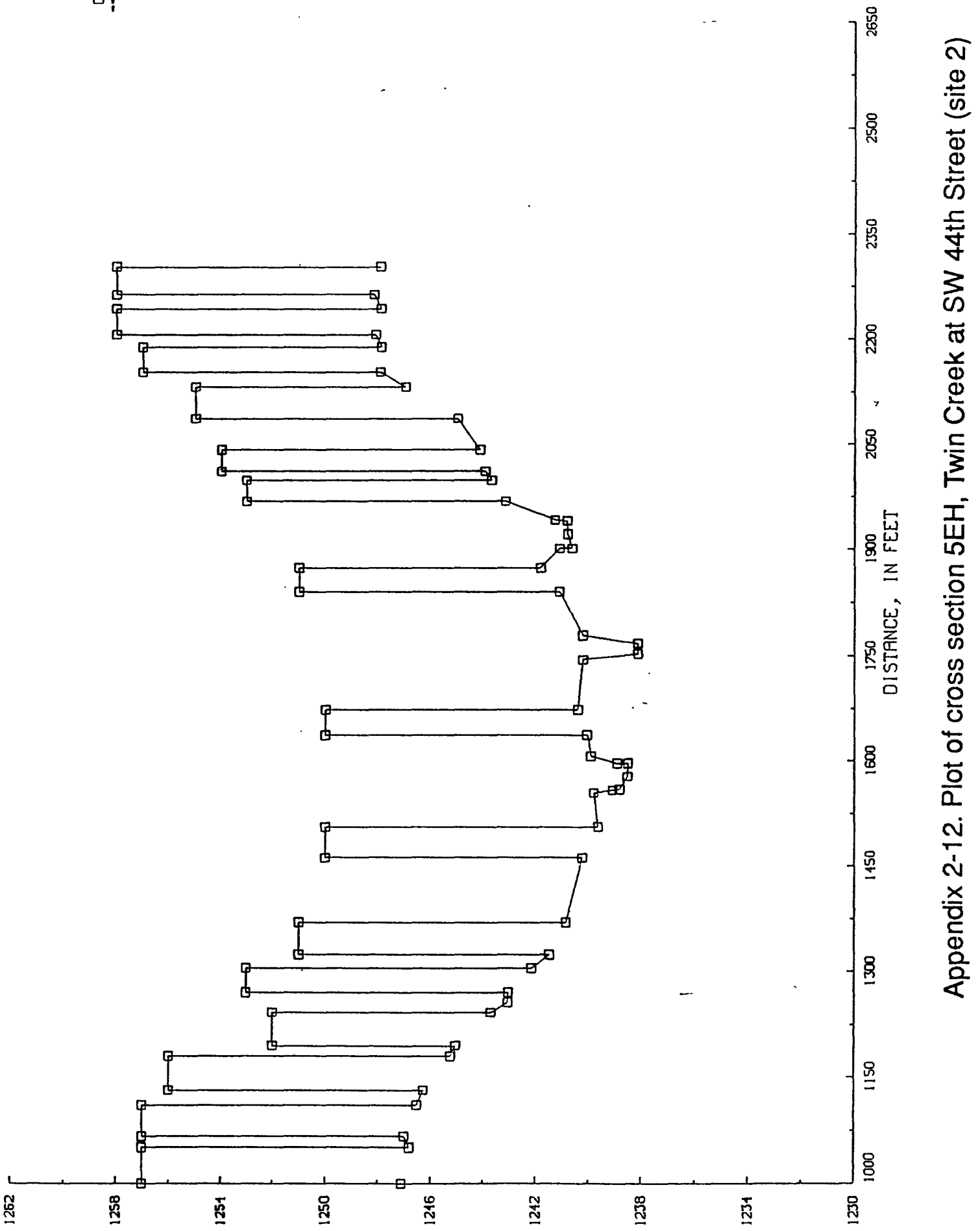

(OAЭN) LI3J NI 'NOILUA373 


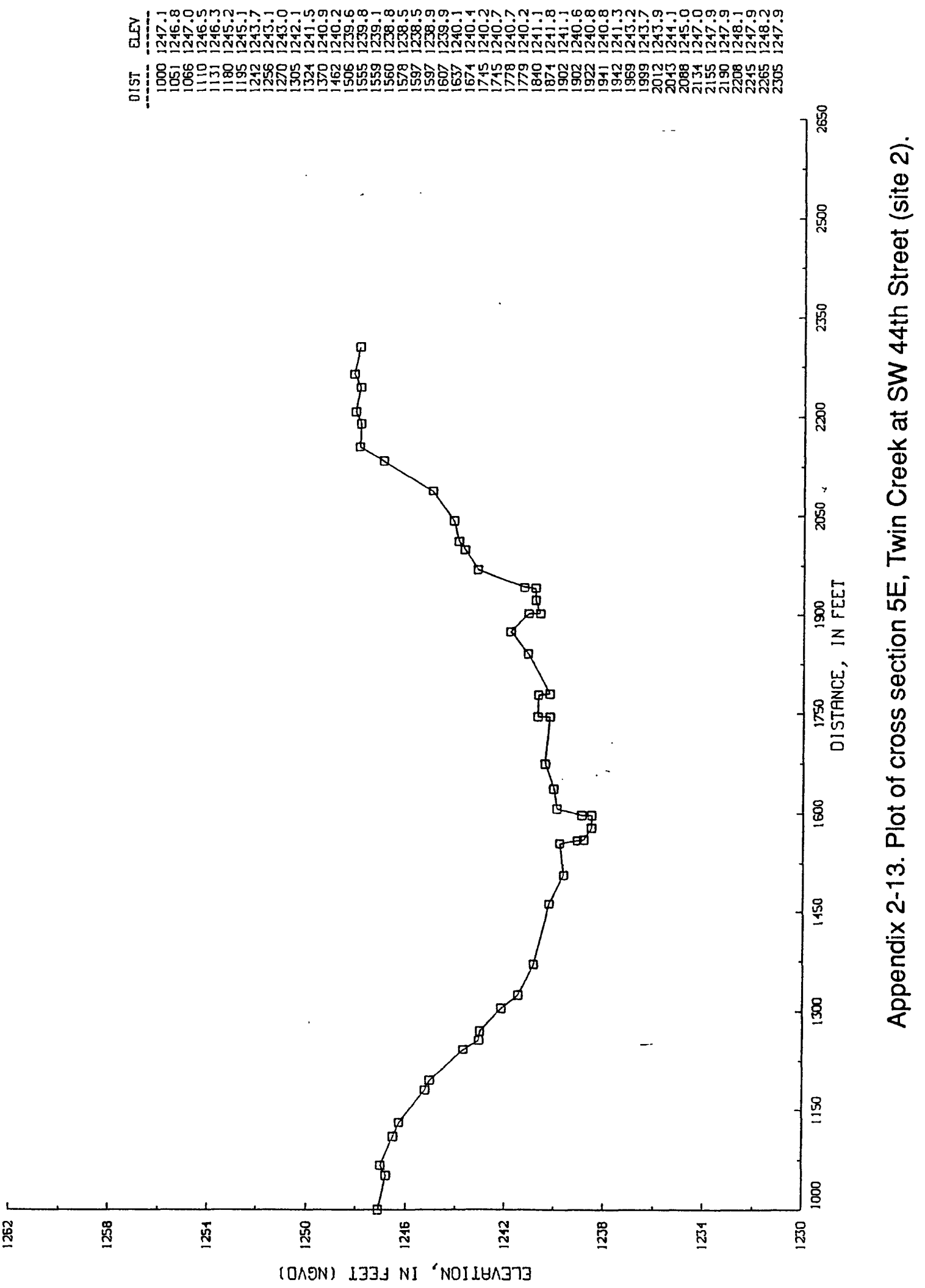

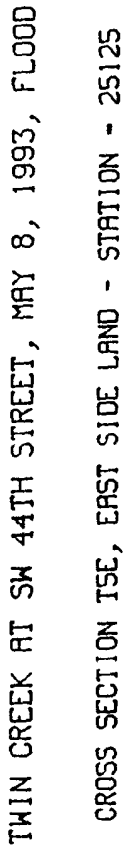




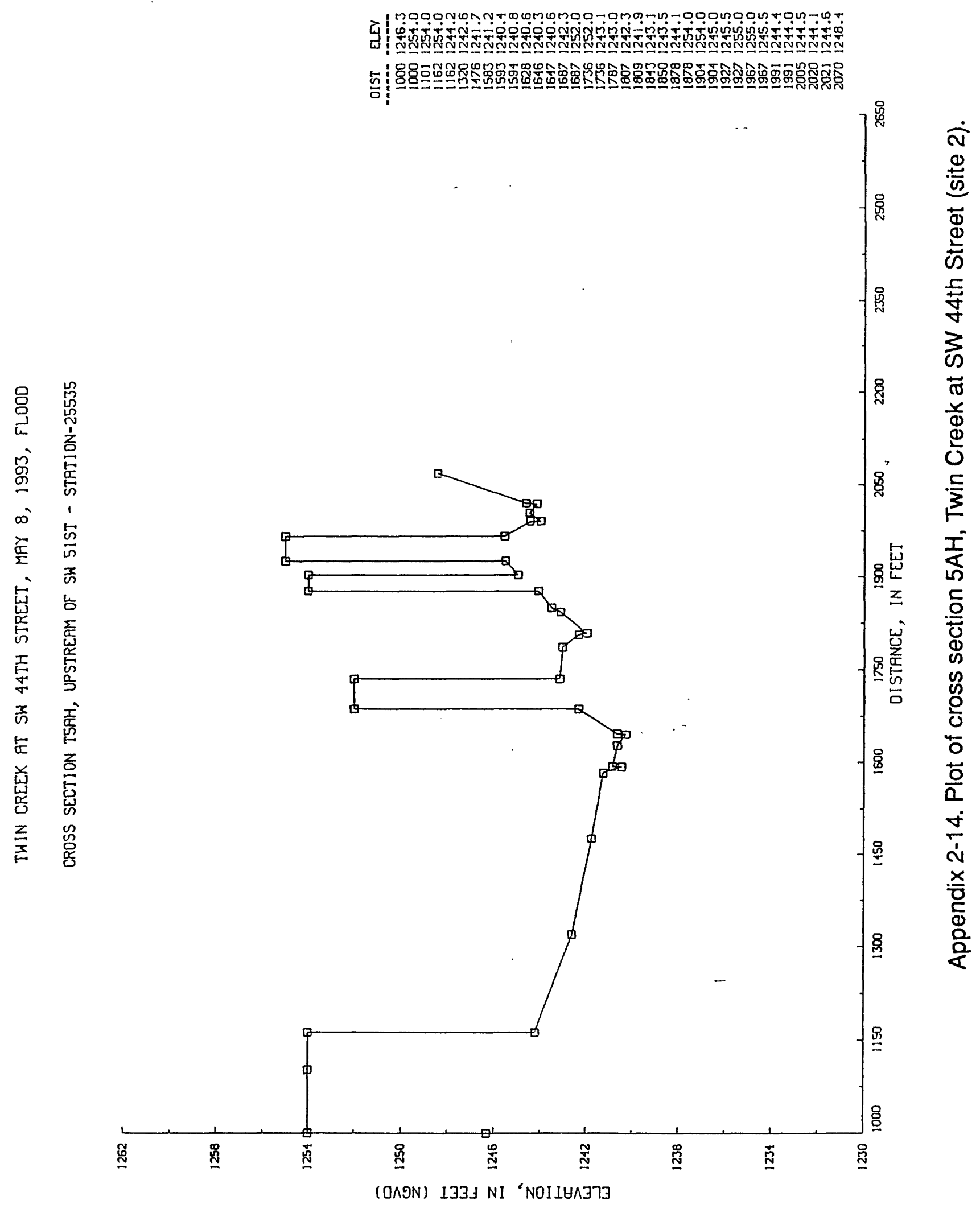




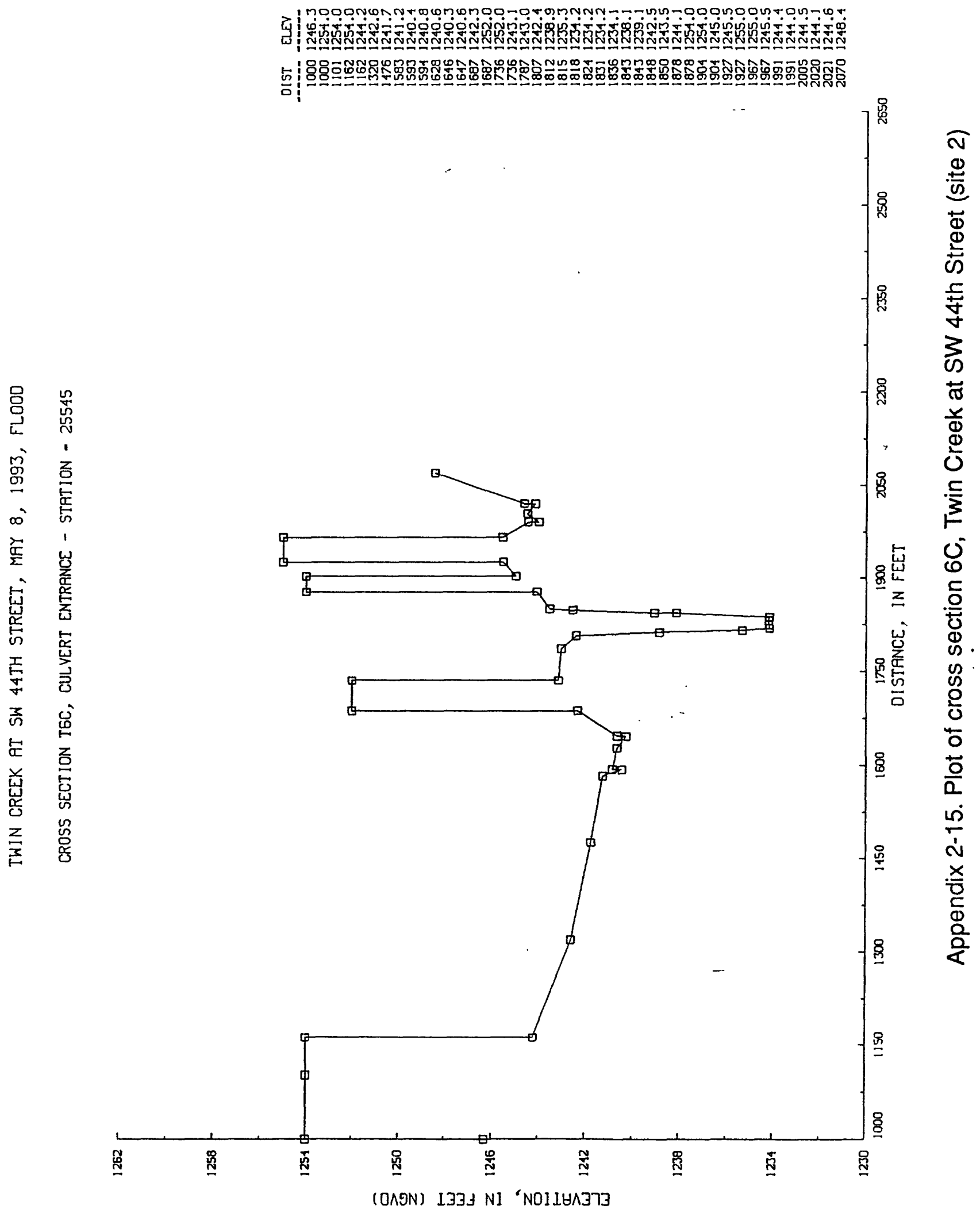




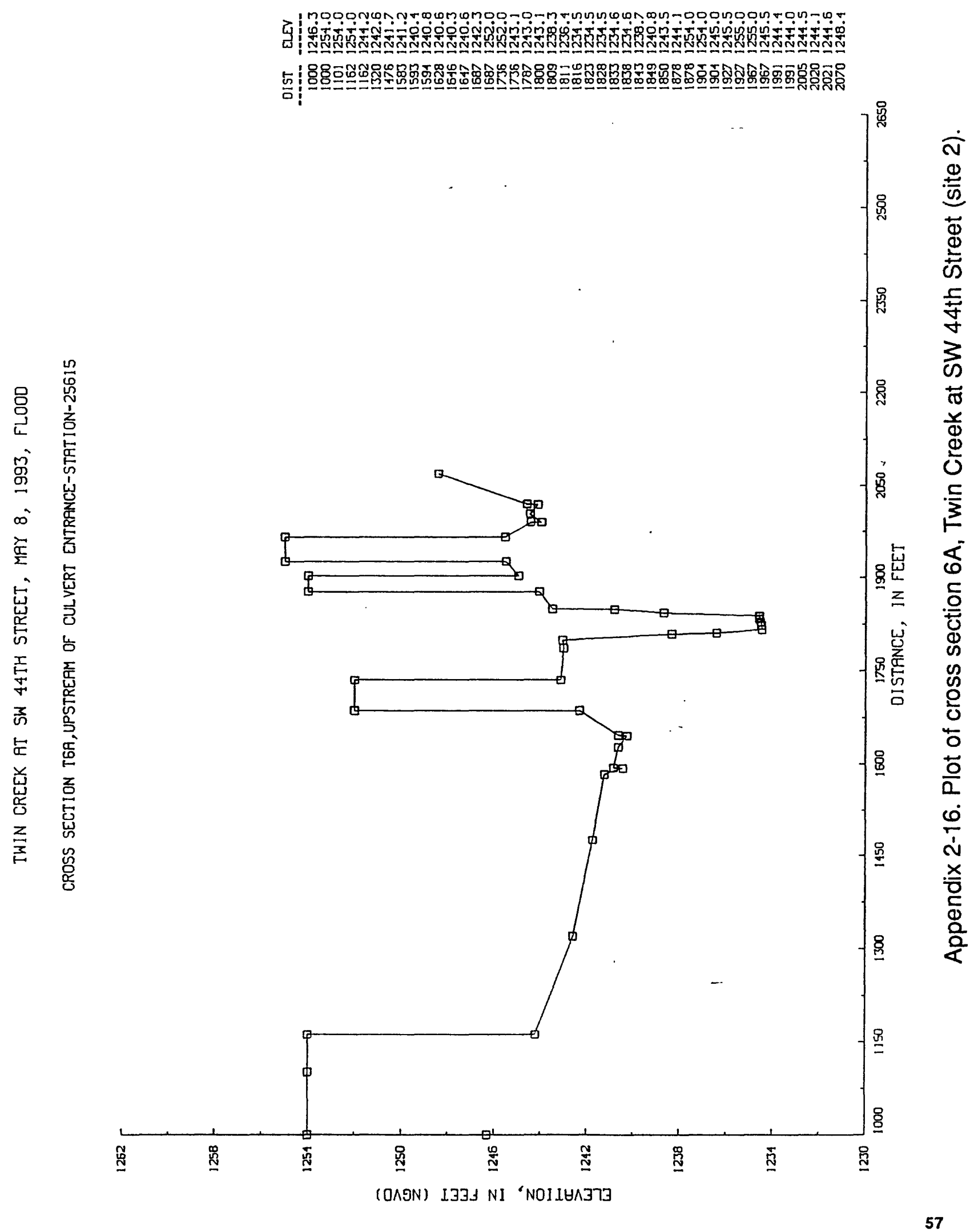




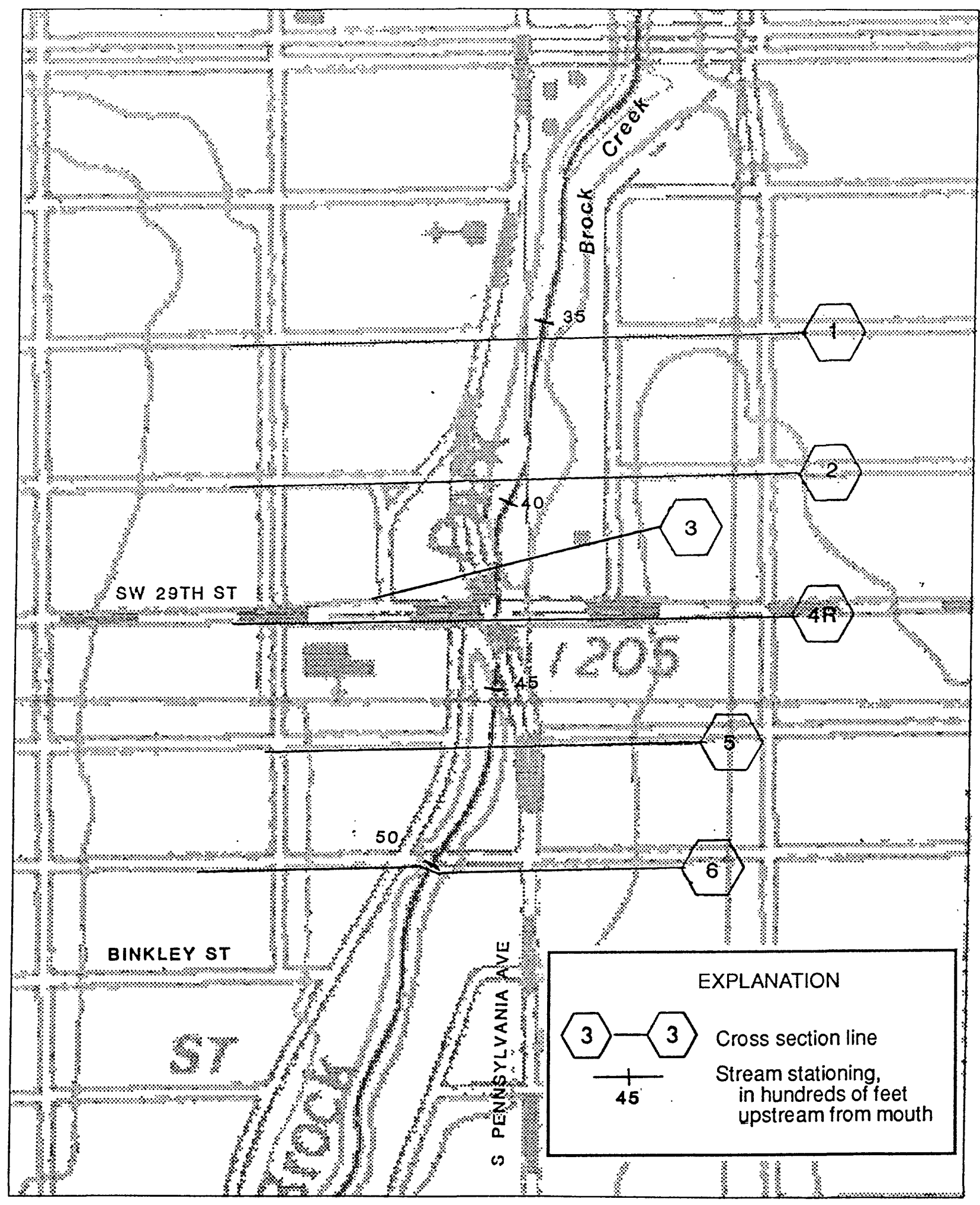

Base from U.S. Geological Survey Digital Raster Graphic, 1:24,000, 1986 Projection: Oklahoma Coordinate System, north zone (Lambert Conformal Conic) 


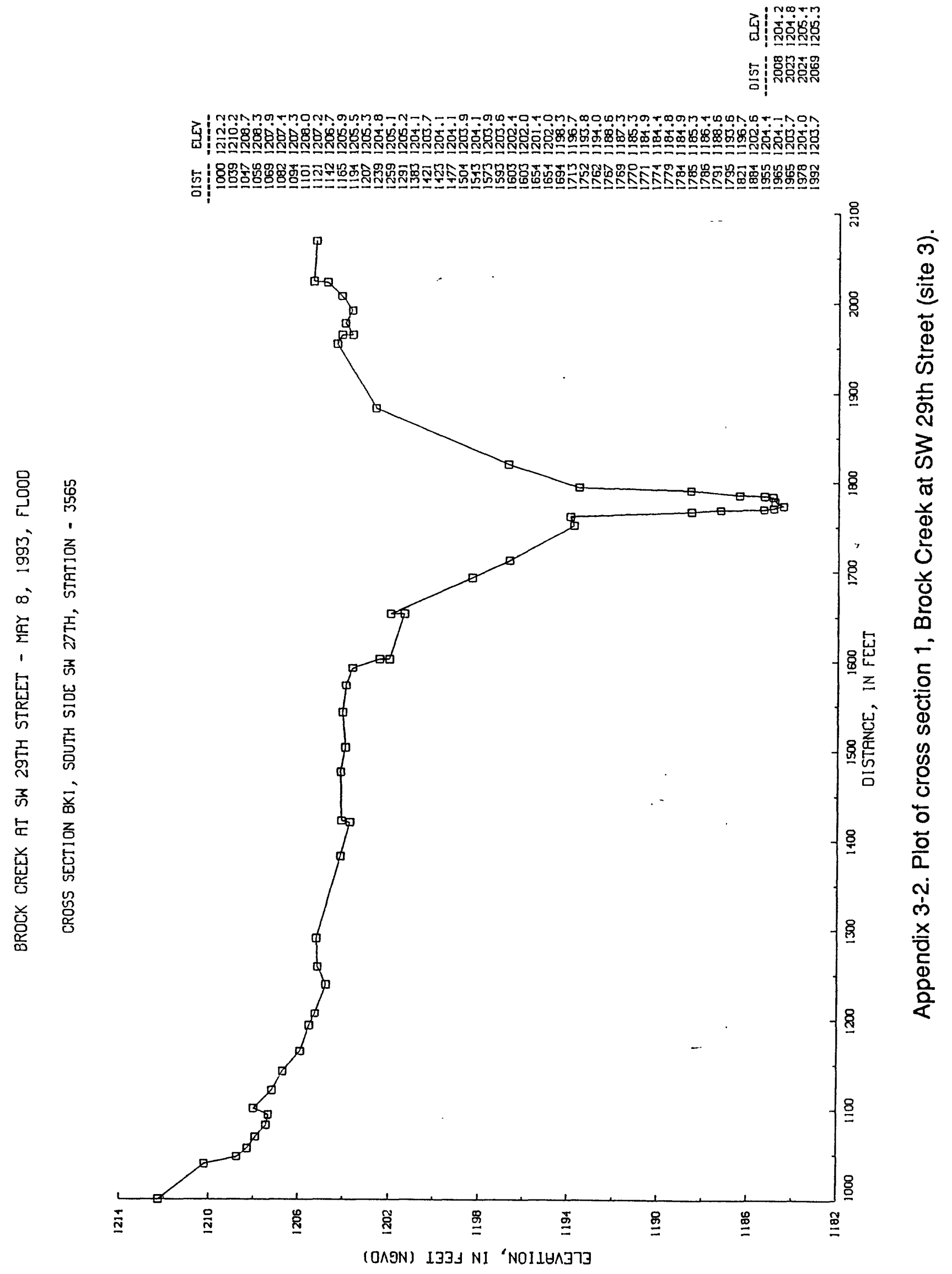




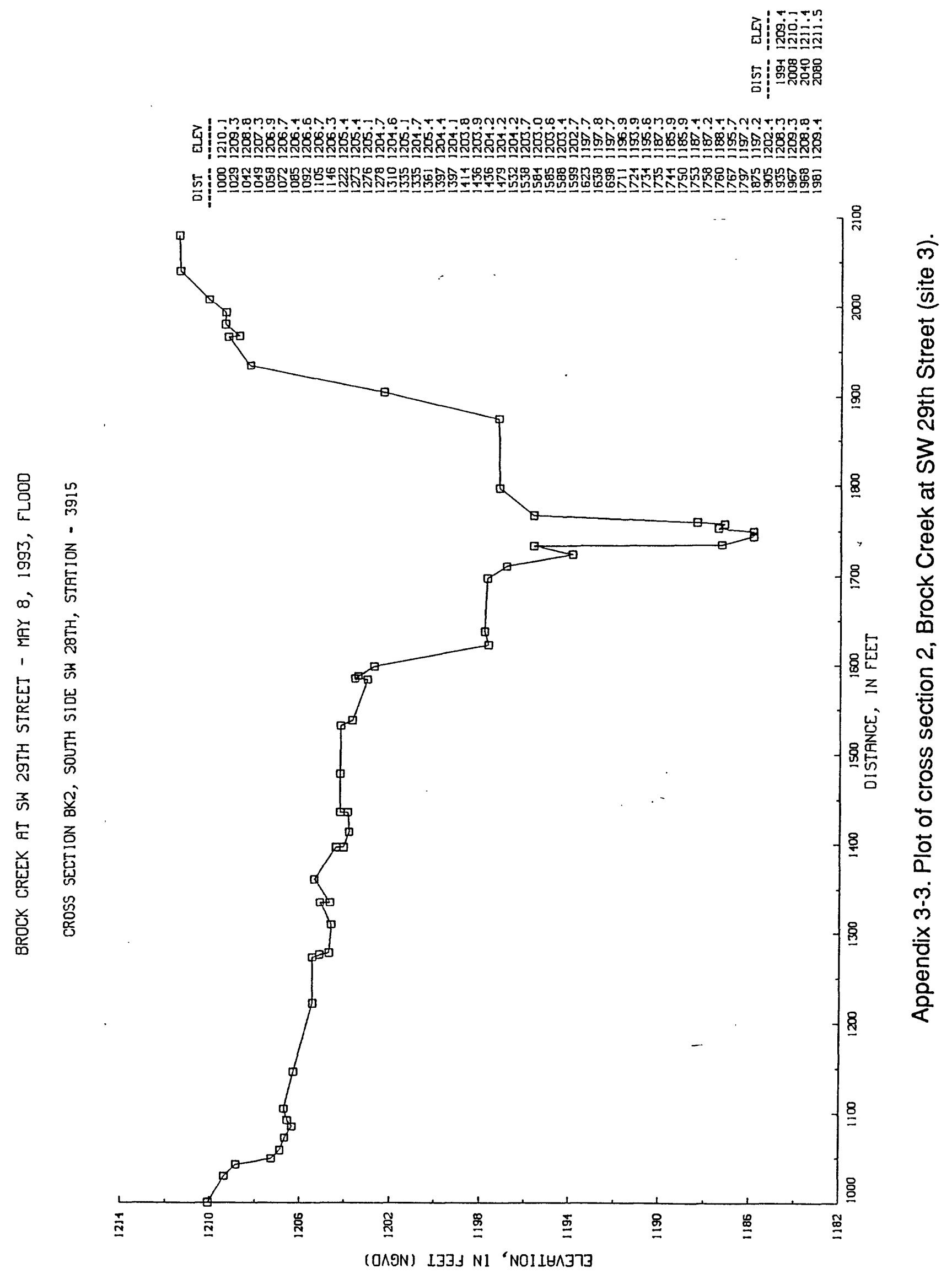

60 Estimated flood peak discharges southwest Oklahoma City, Oklahoma, May 8, 1993 


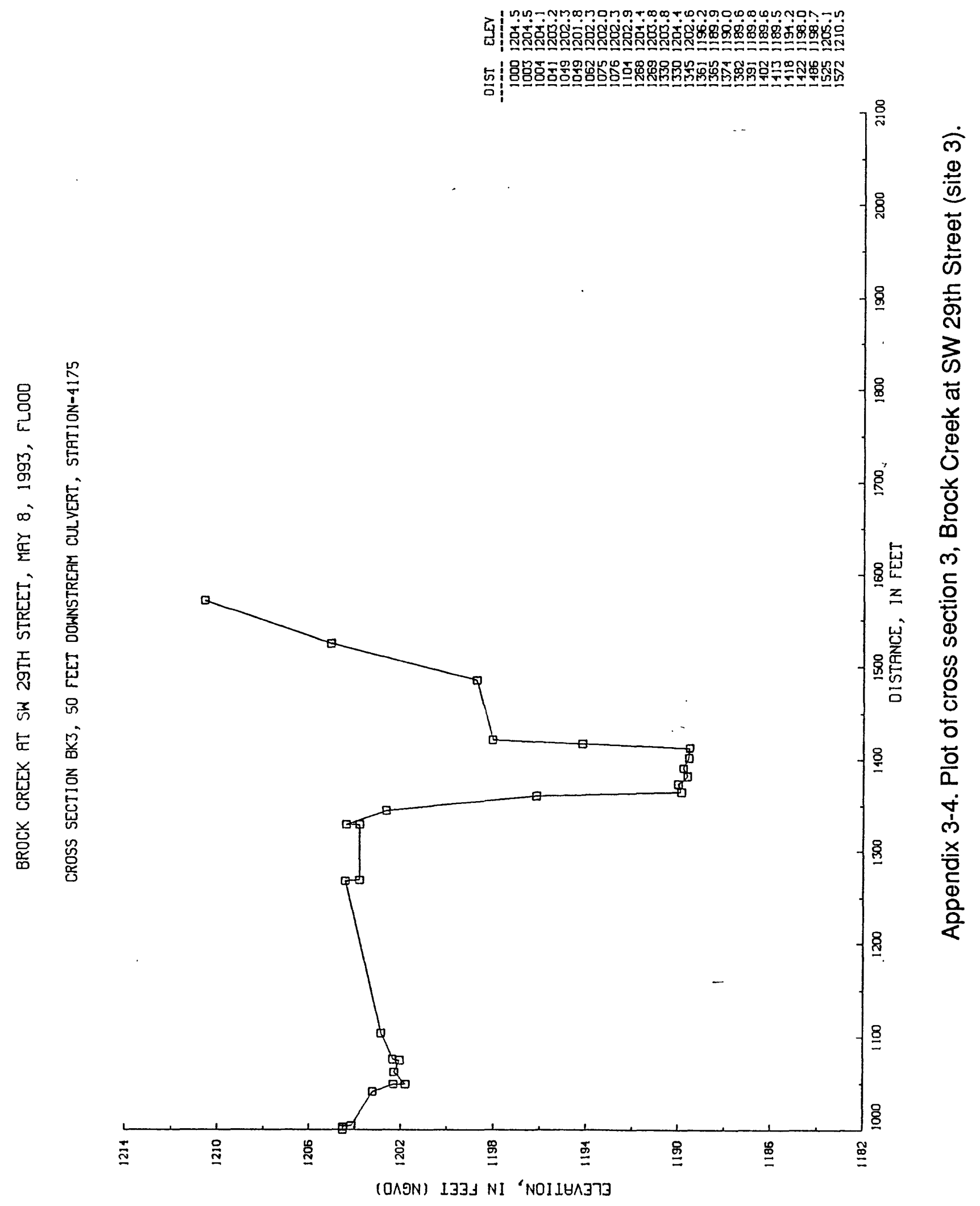




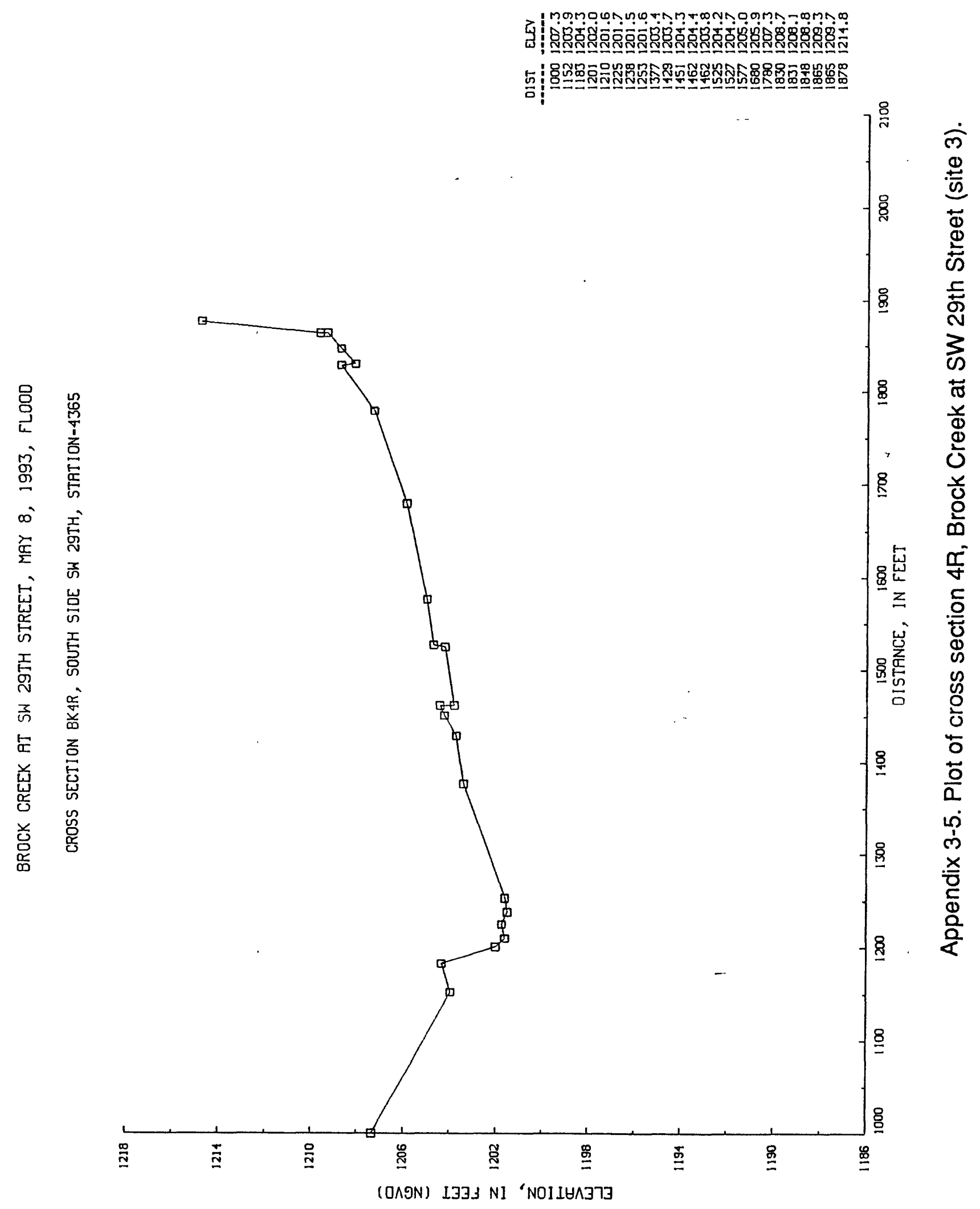

62 Estimated flood peak discharges southwest Oklahoma City, Oklahoma, May 8, 1993 


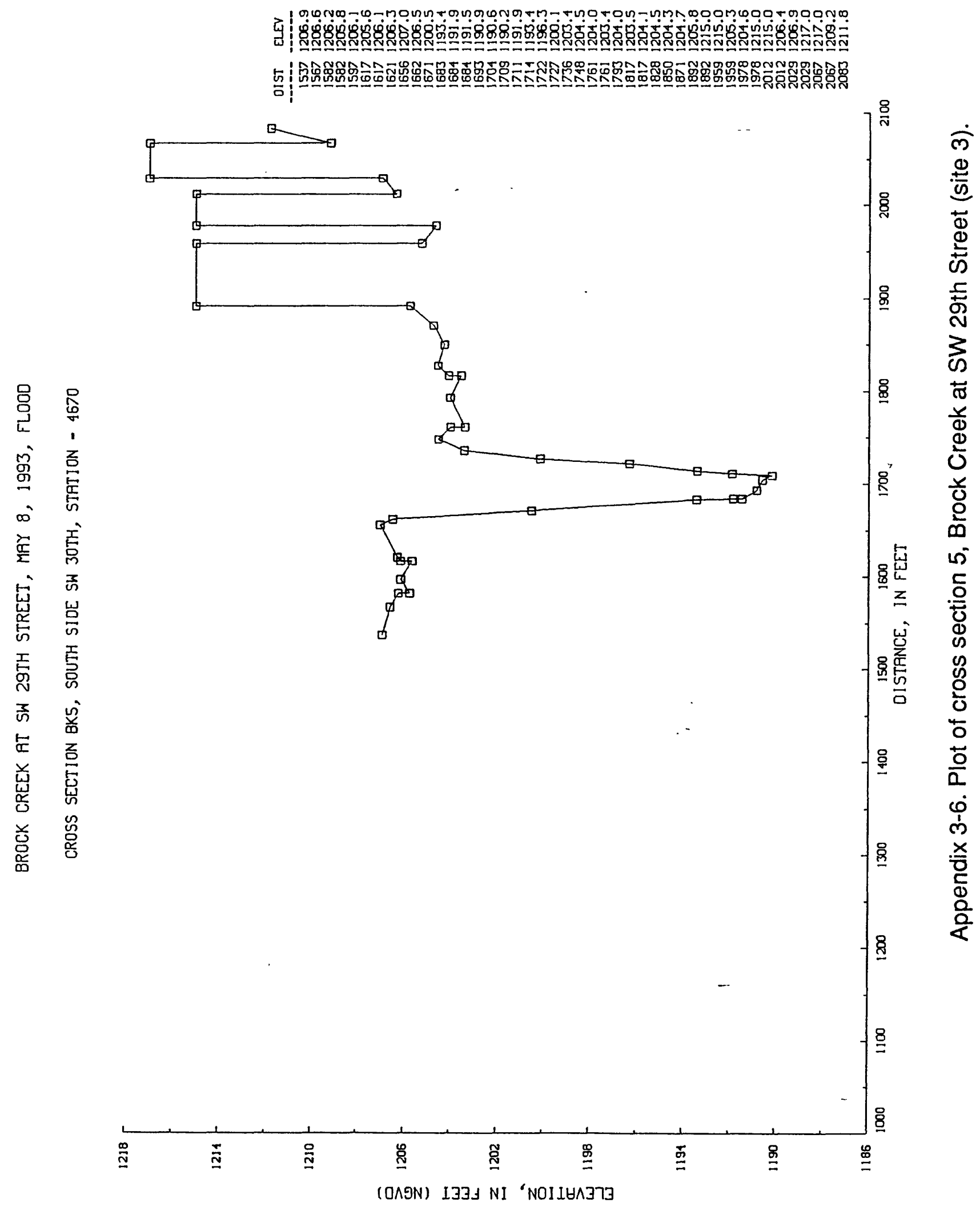




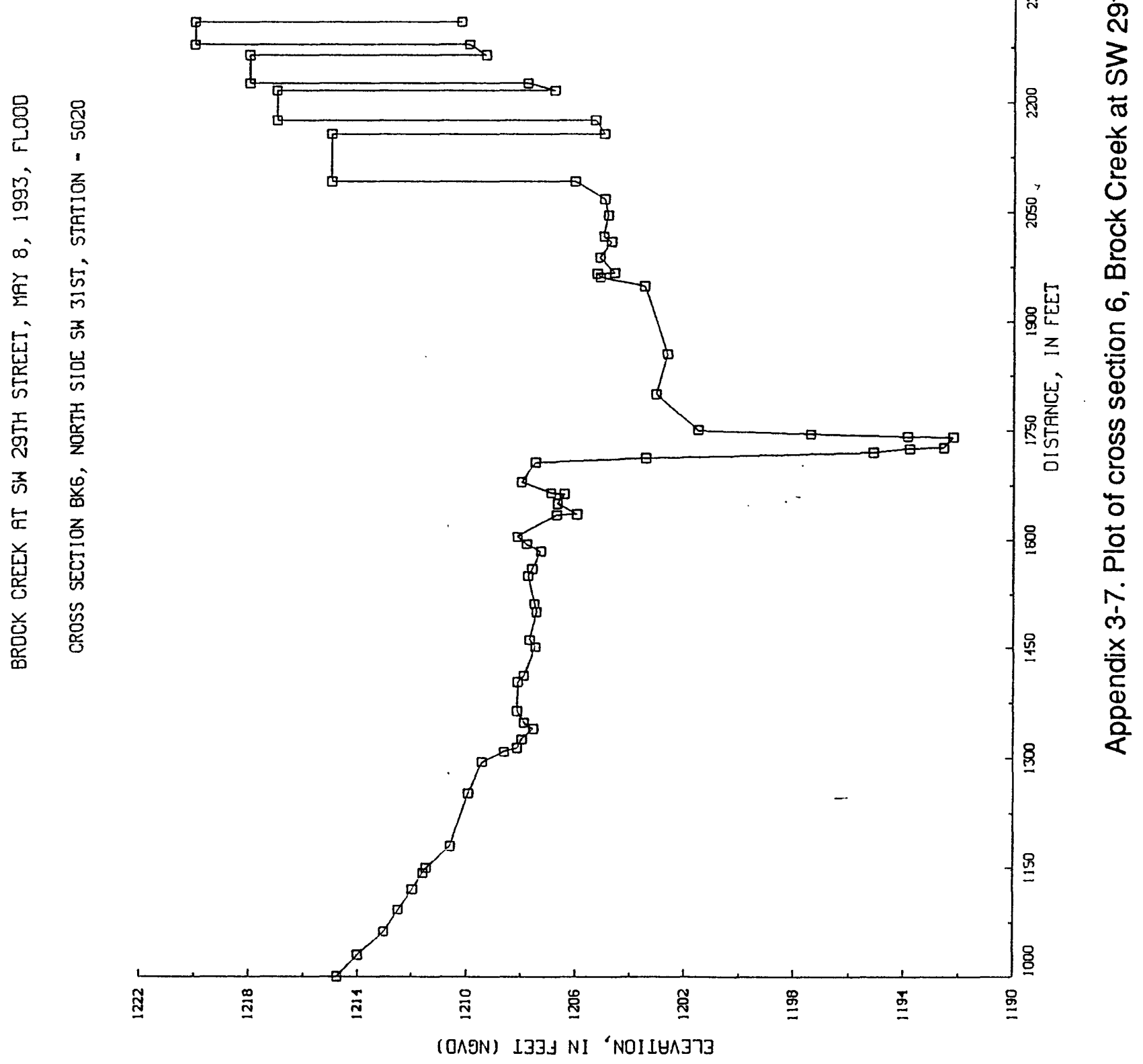




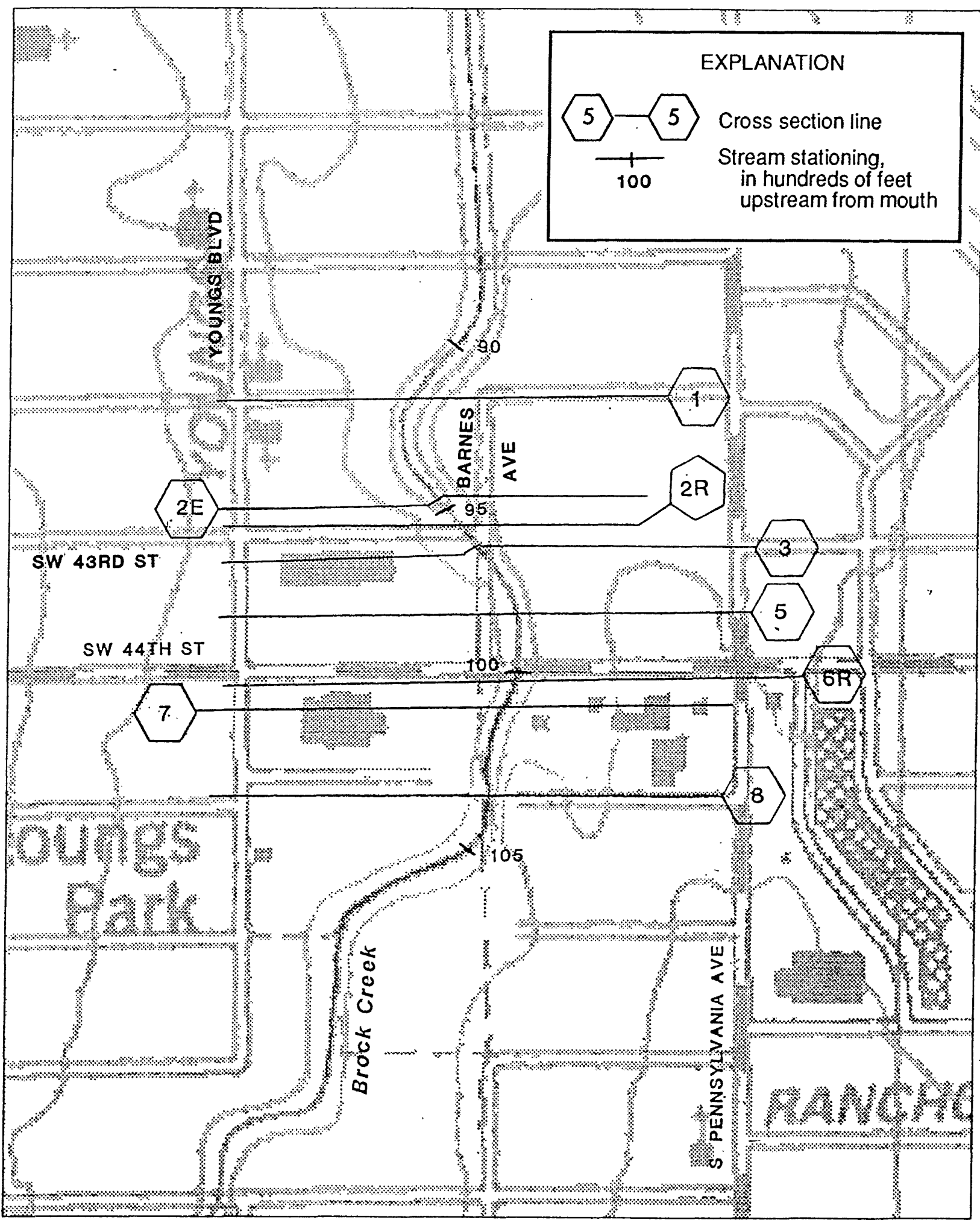

Base from U.S. Geological Survey Digital Raster Graphic, 1:24,000, 1986 Projection: Oklahoma Coordinate System, north zone (Lambert Conformal Conic) 0,100 FEET
0
50 

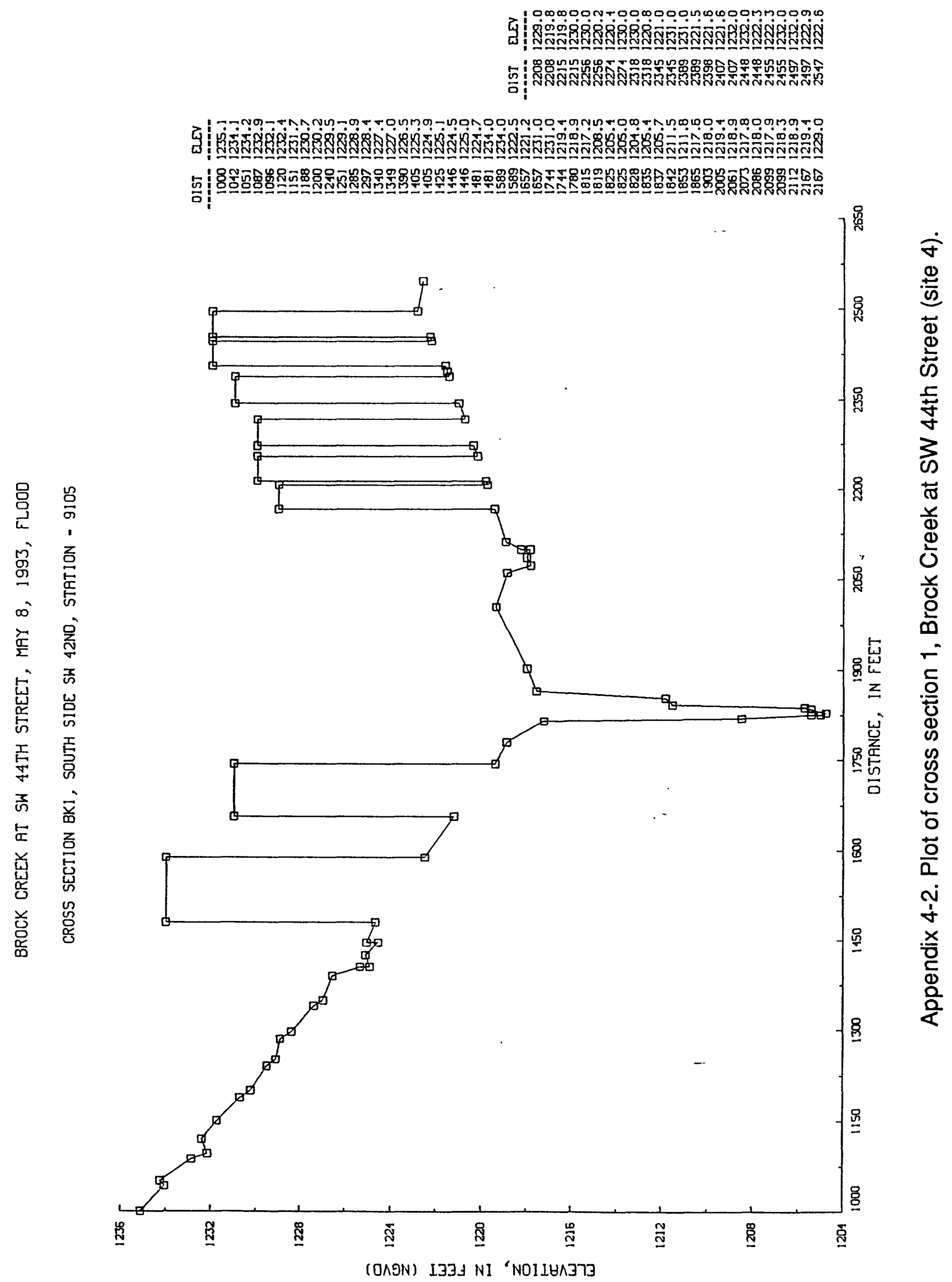


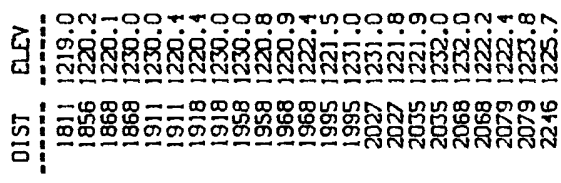

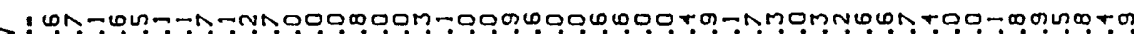

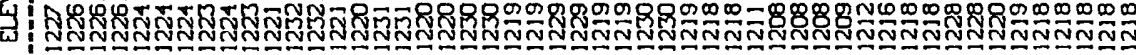

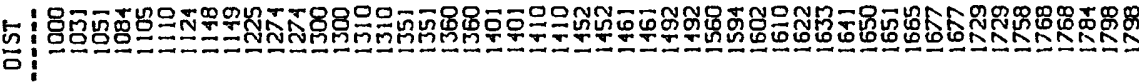

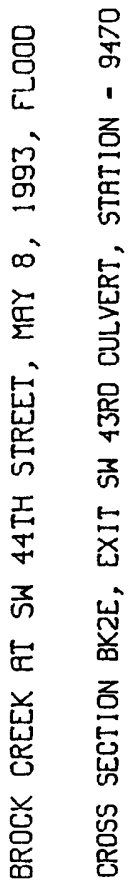

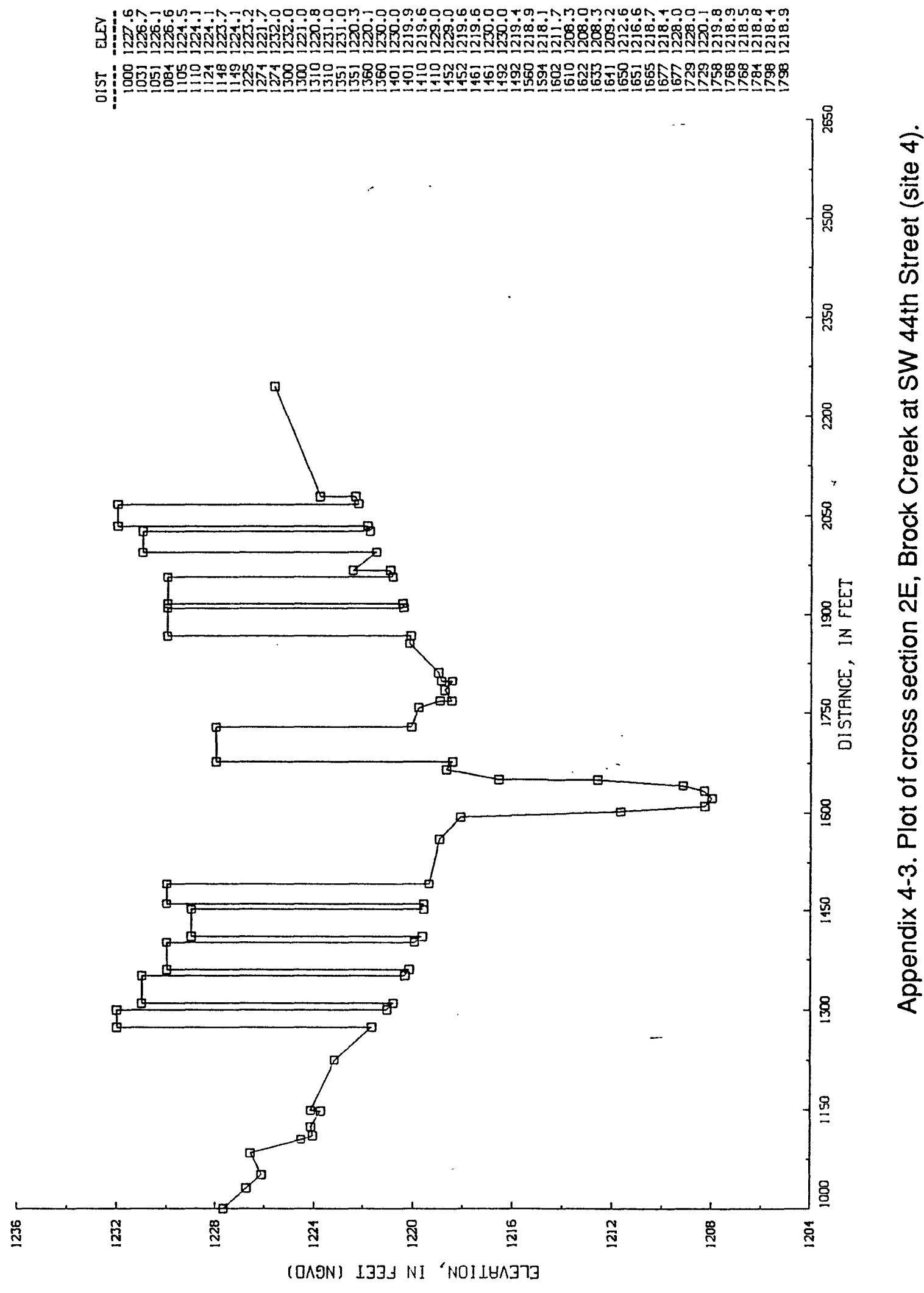



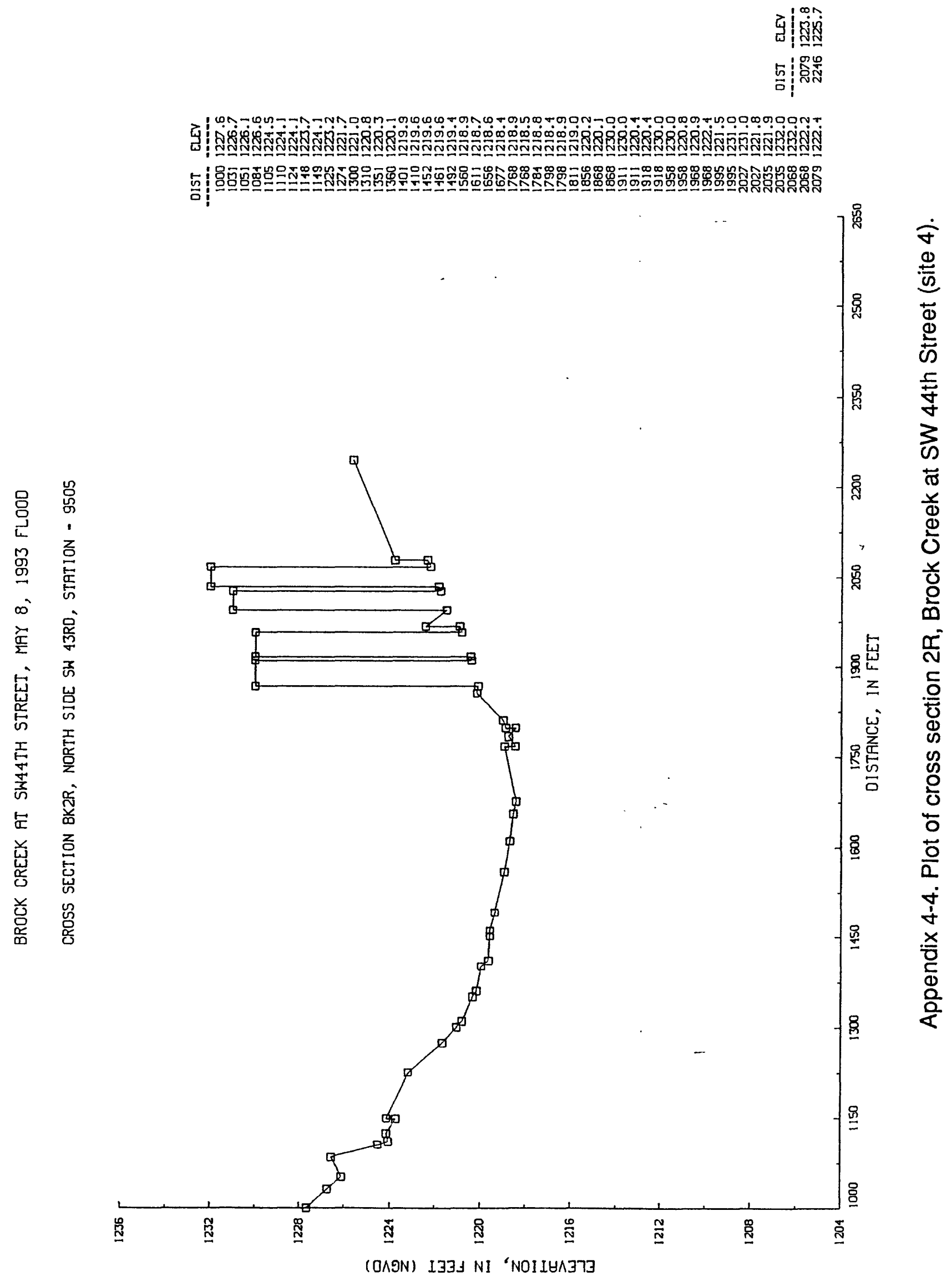


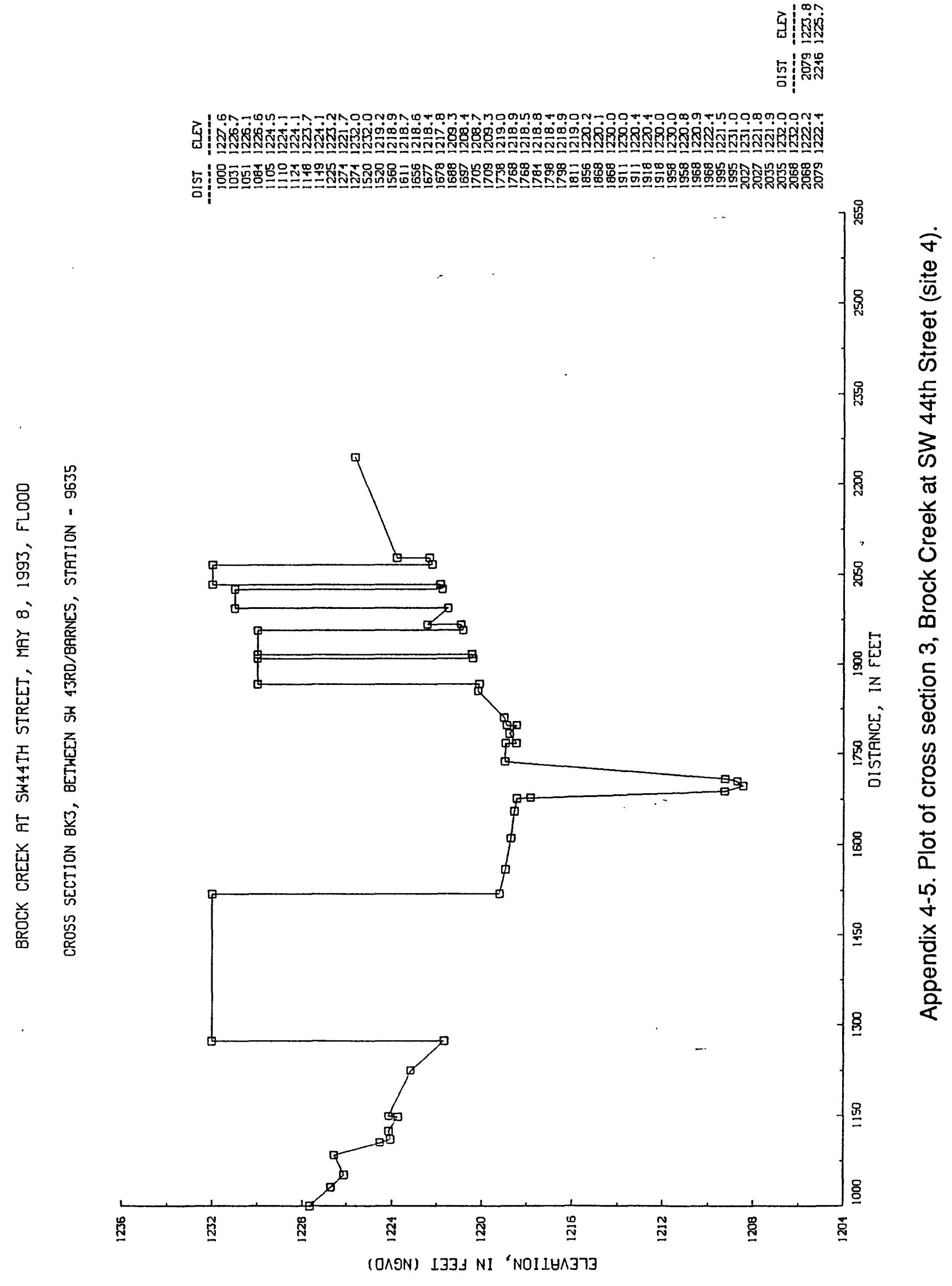




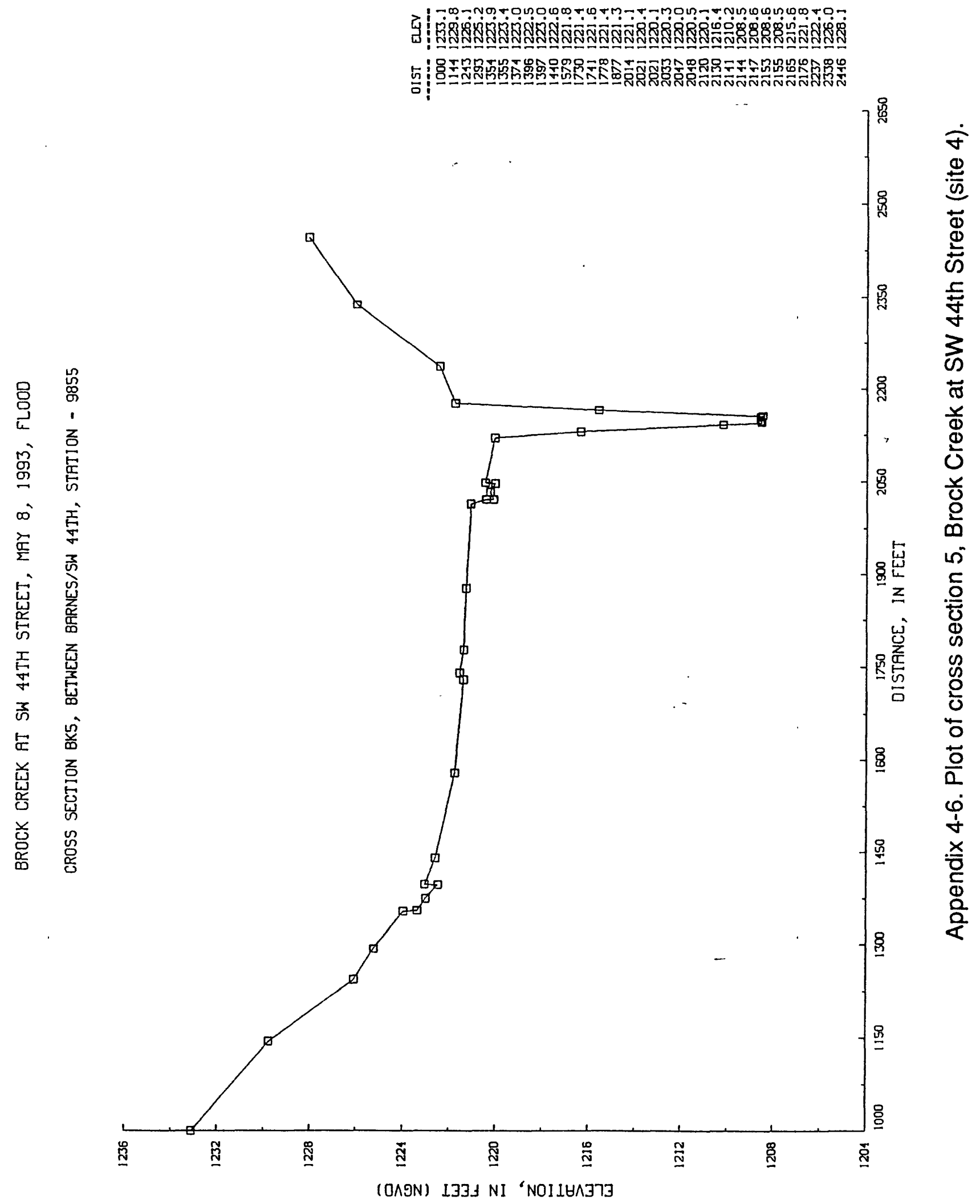




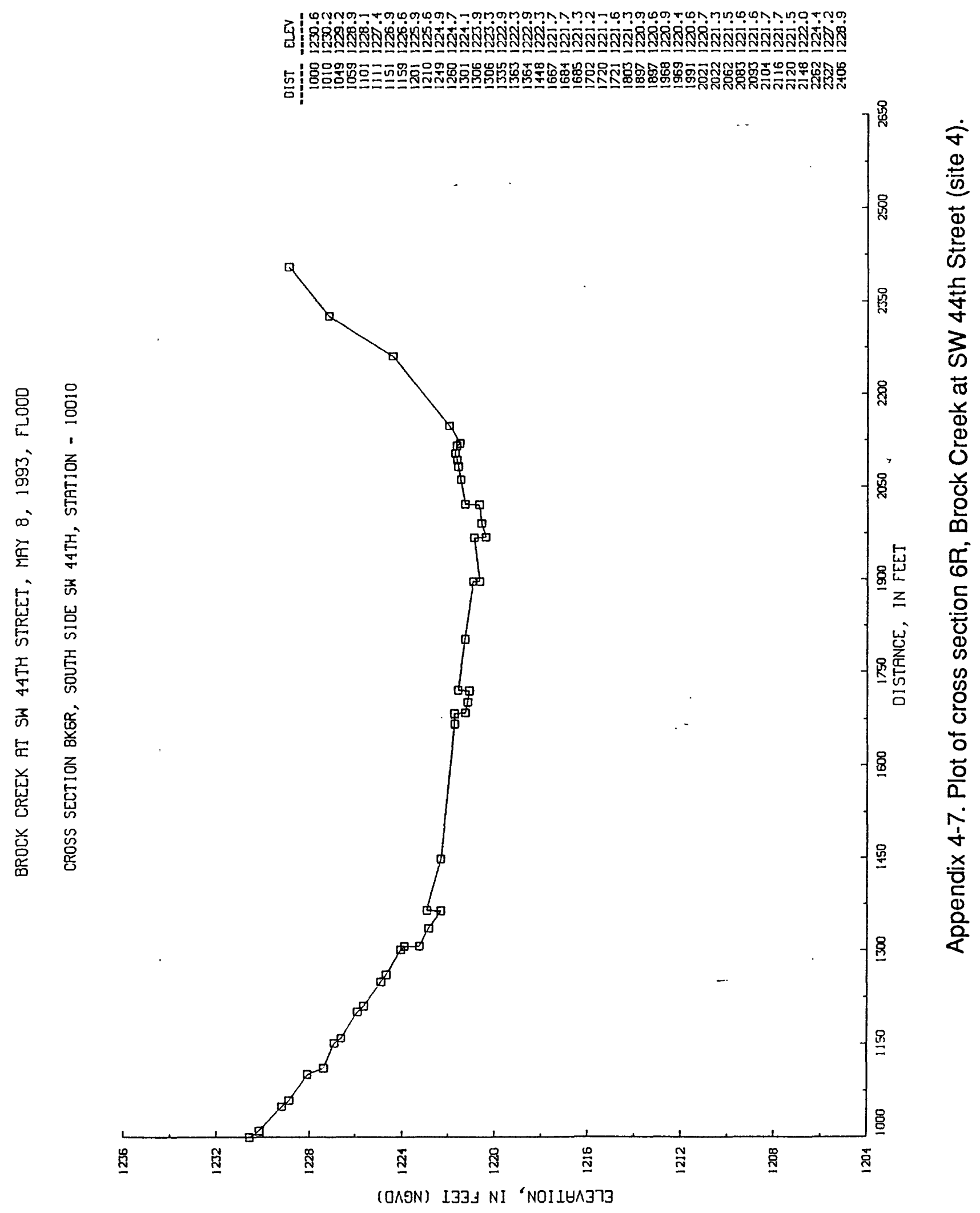



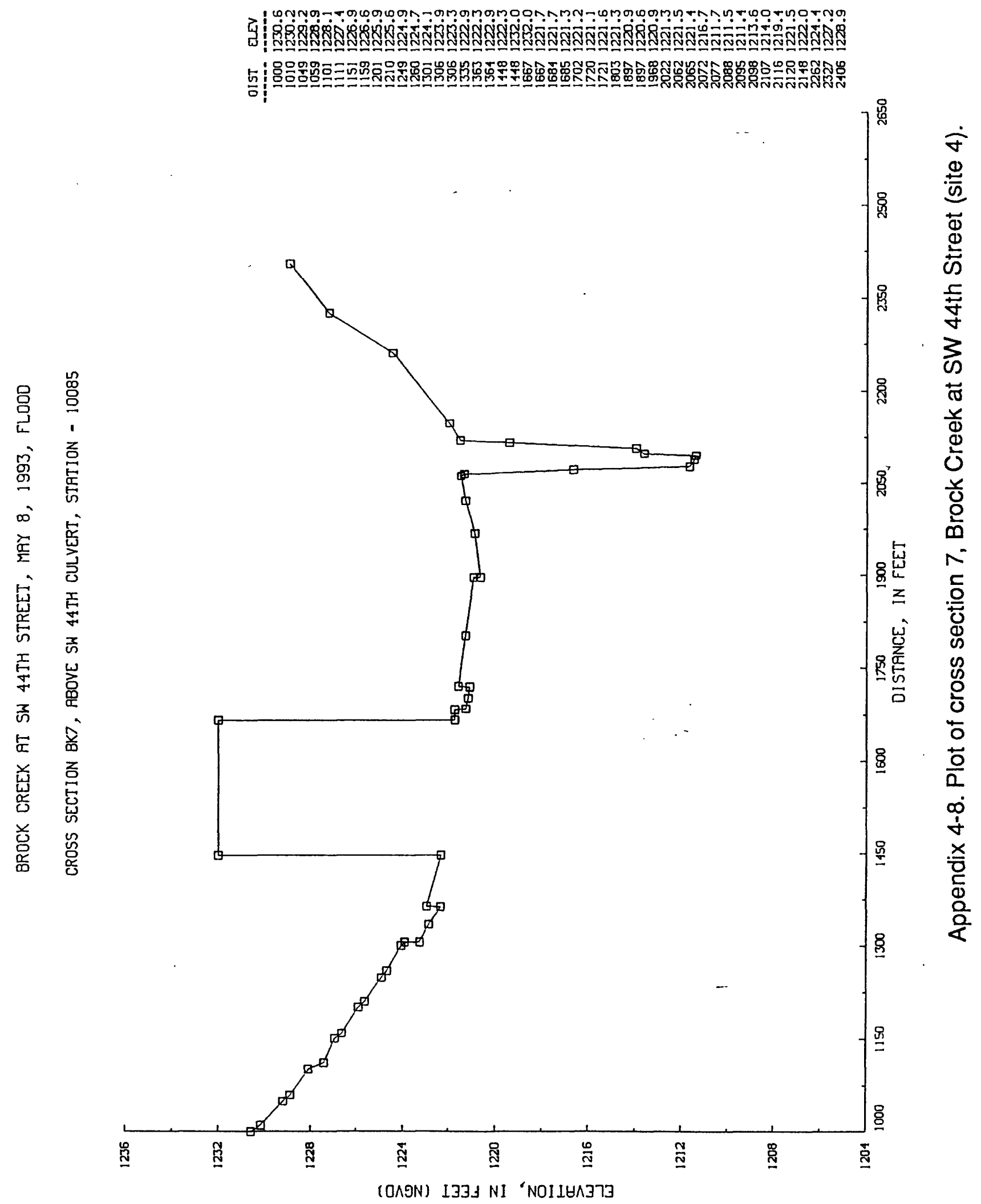


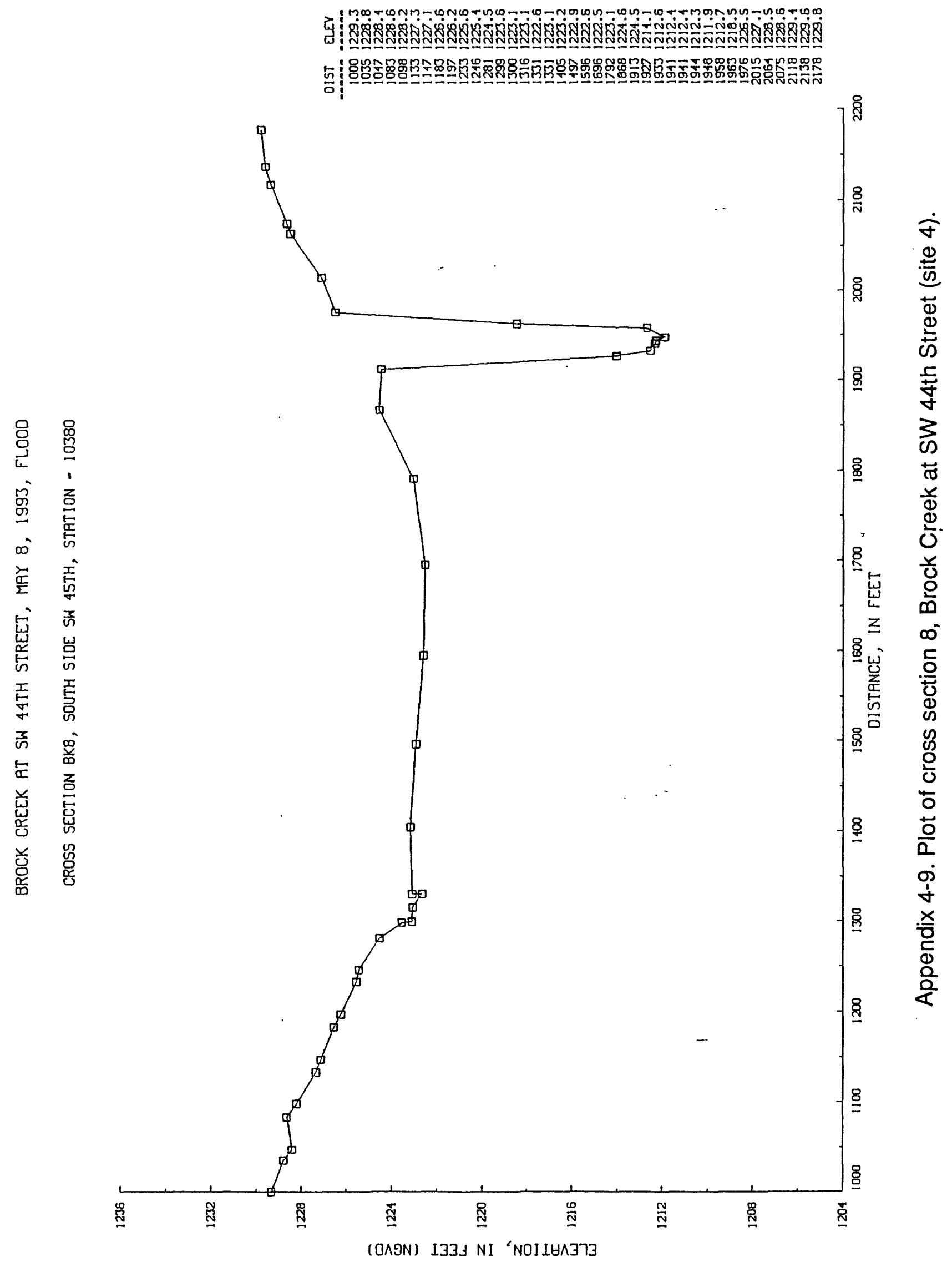




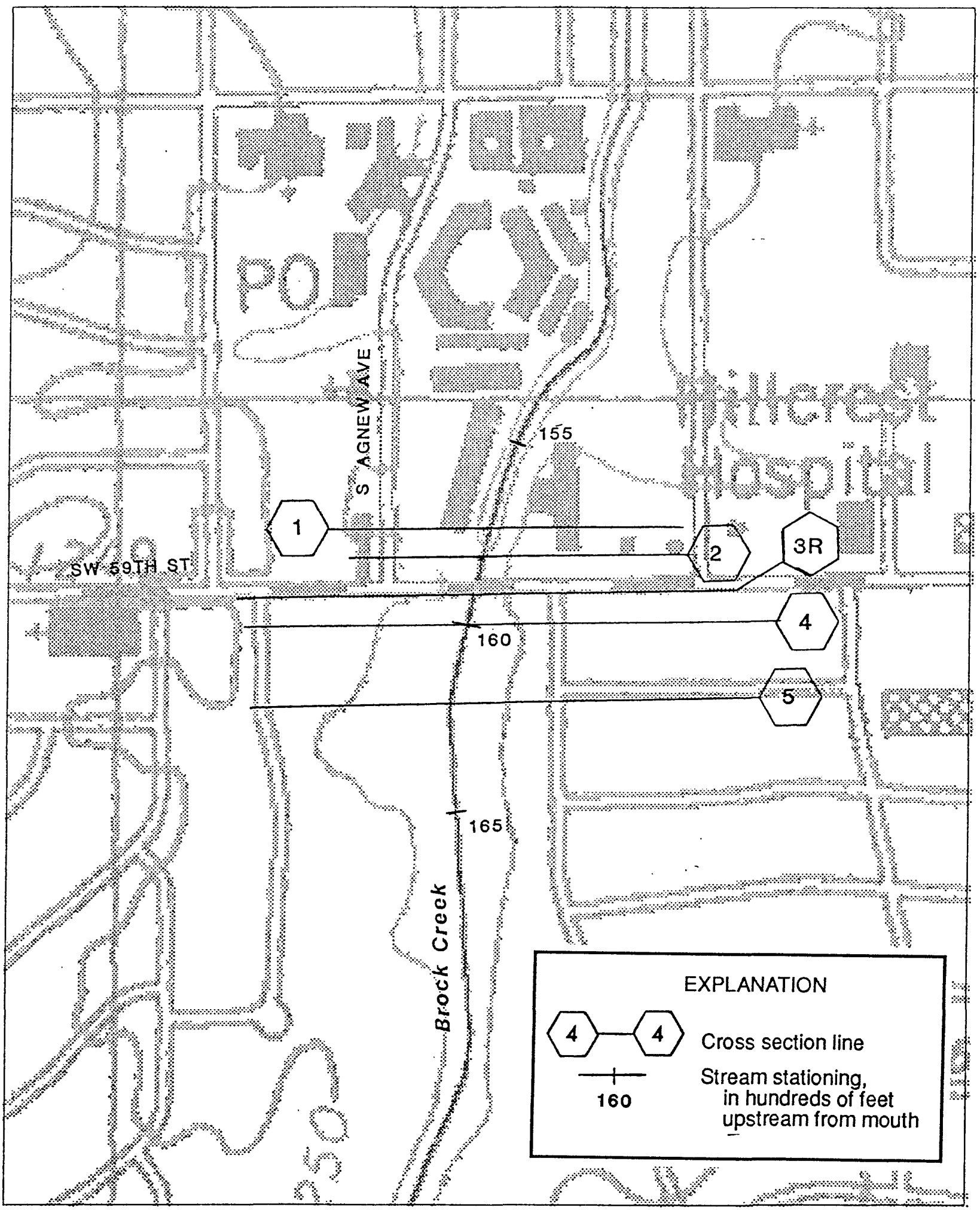

Base from U.S. Geological Survey Digital Raster Graphic, 1:24,000, 1986 Projection: Oklahoma Coordinate System, north zone (Lambert Conformal Conic) 


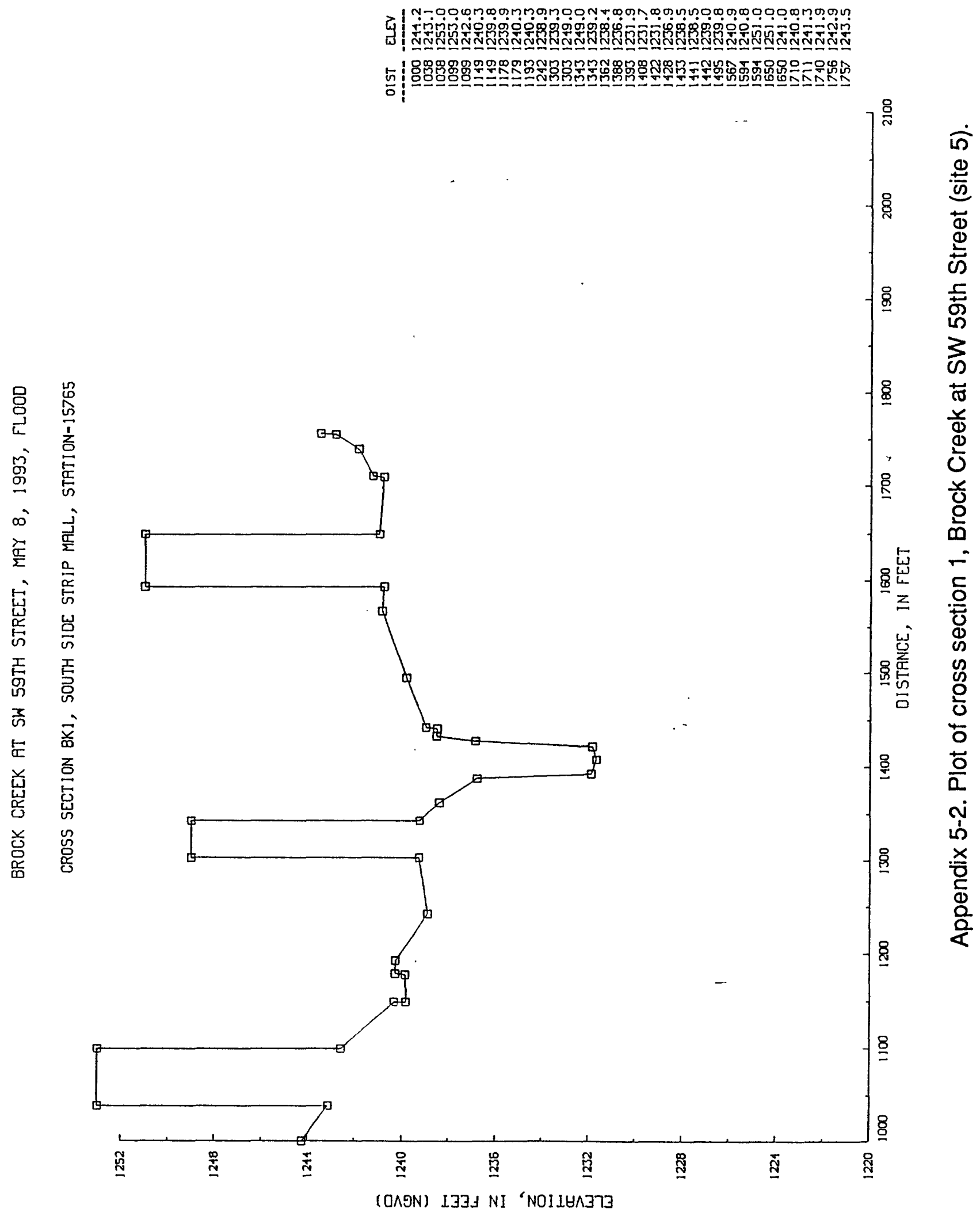




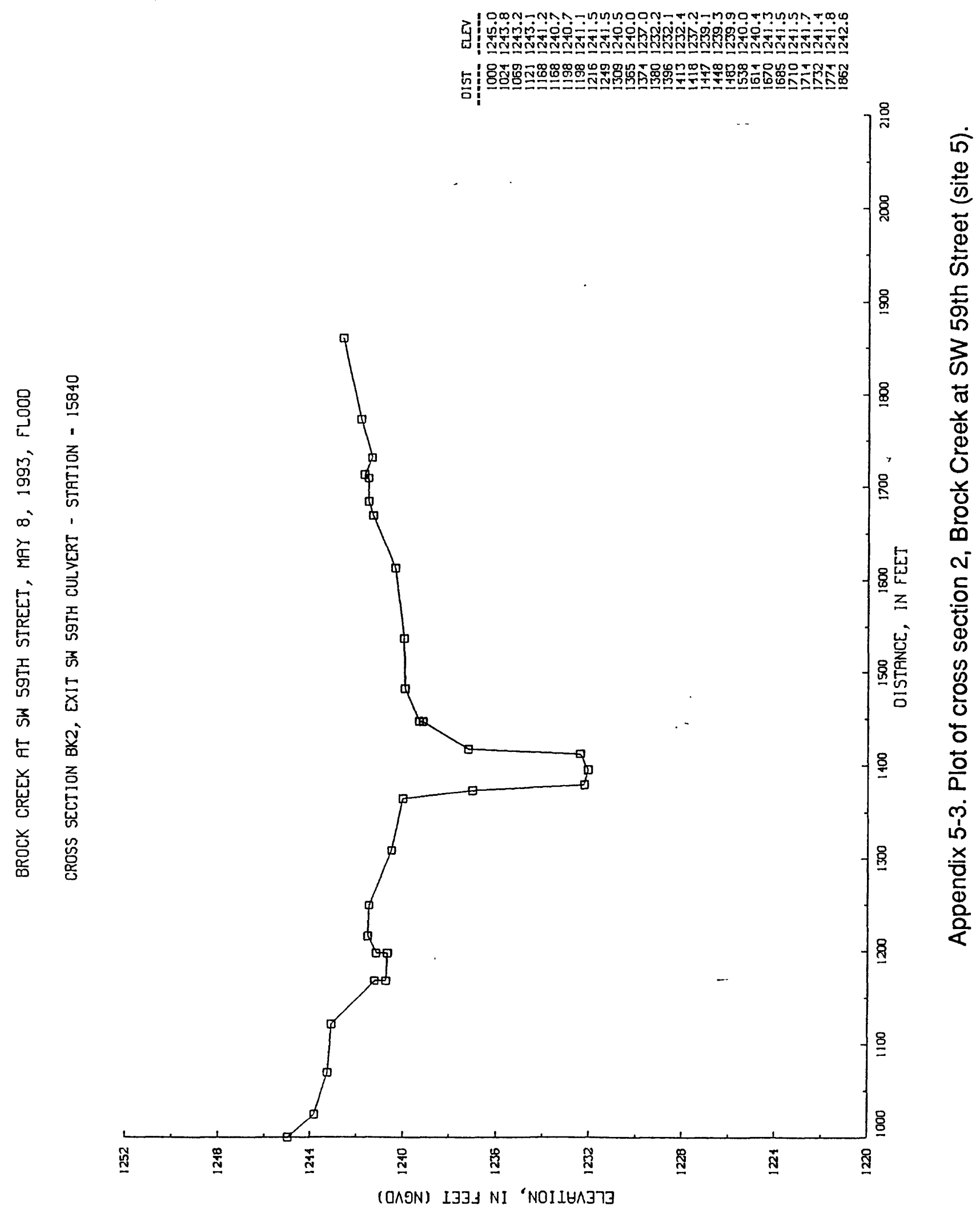




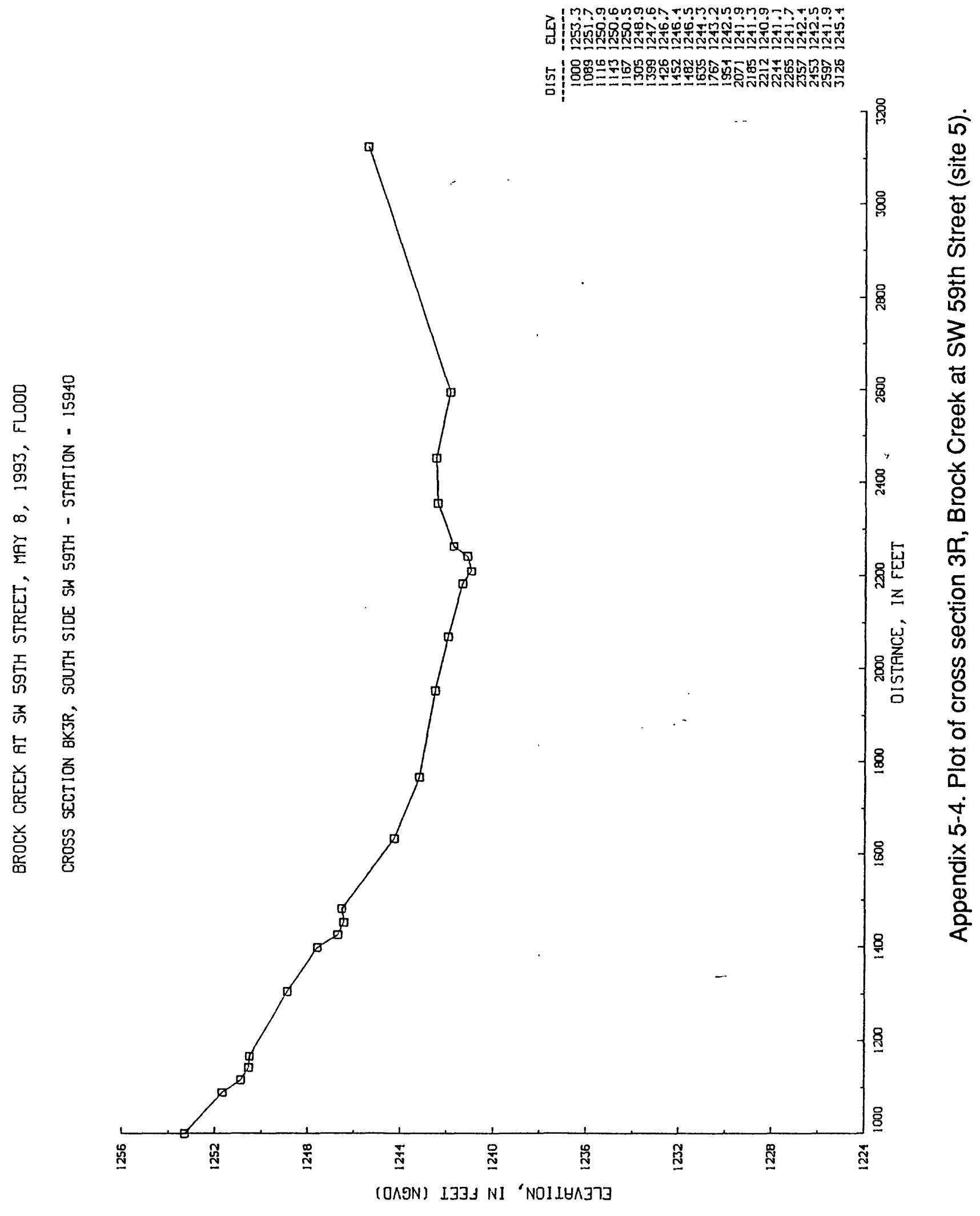




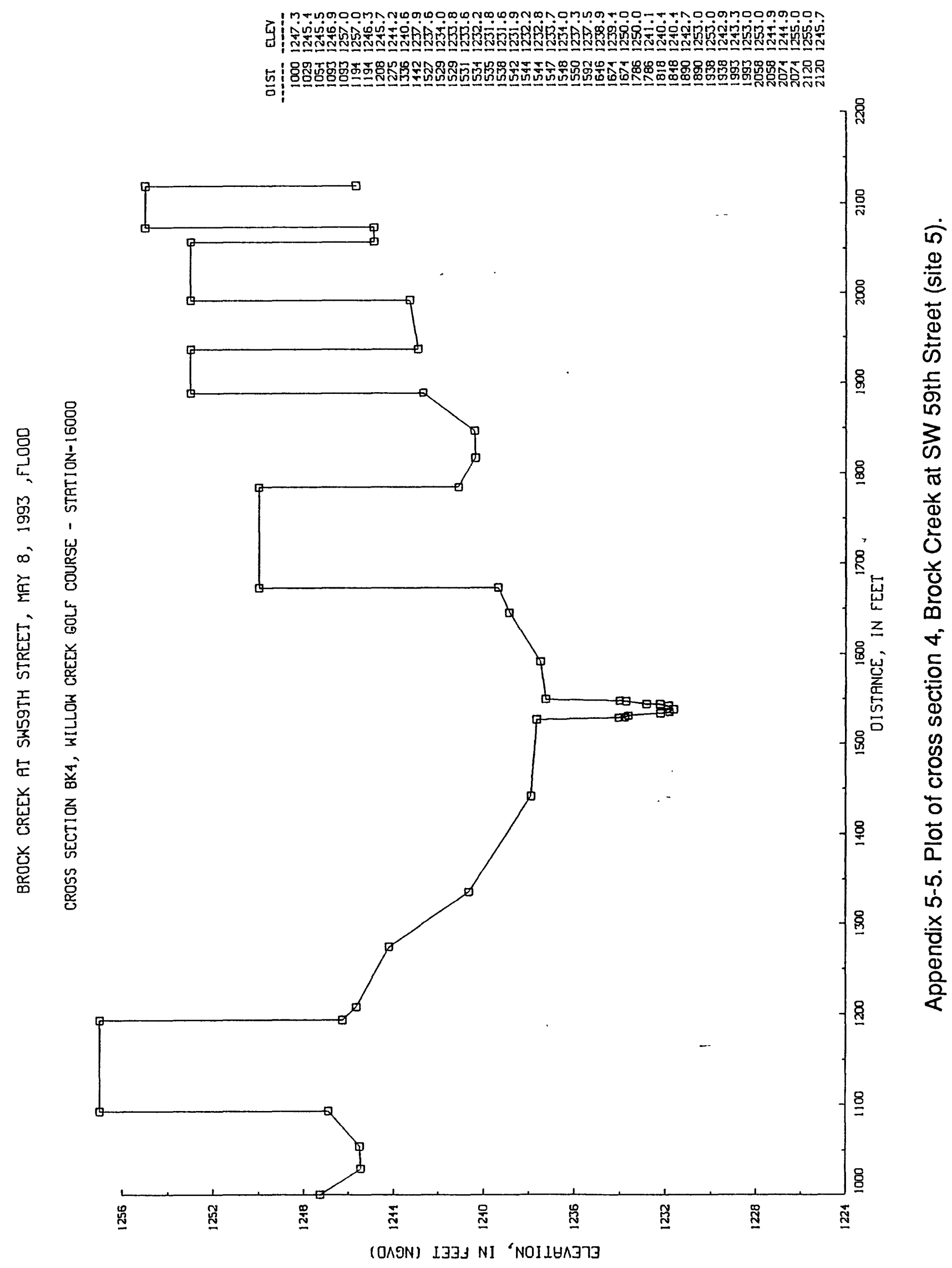



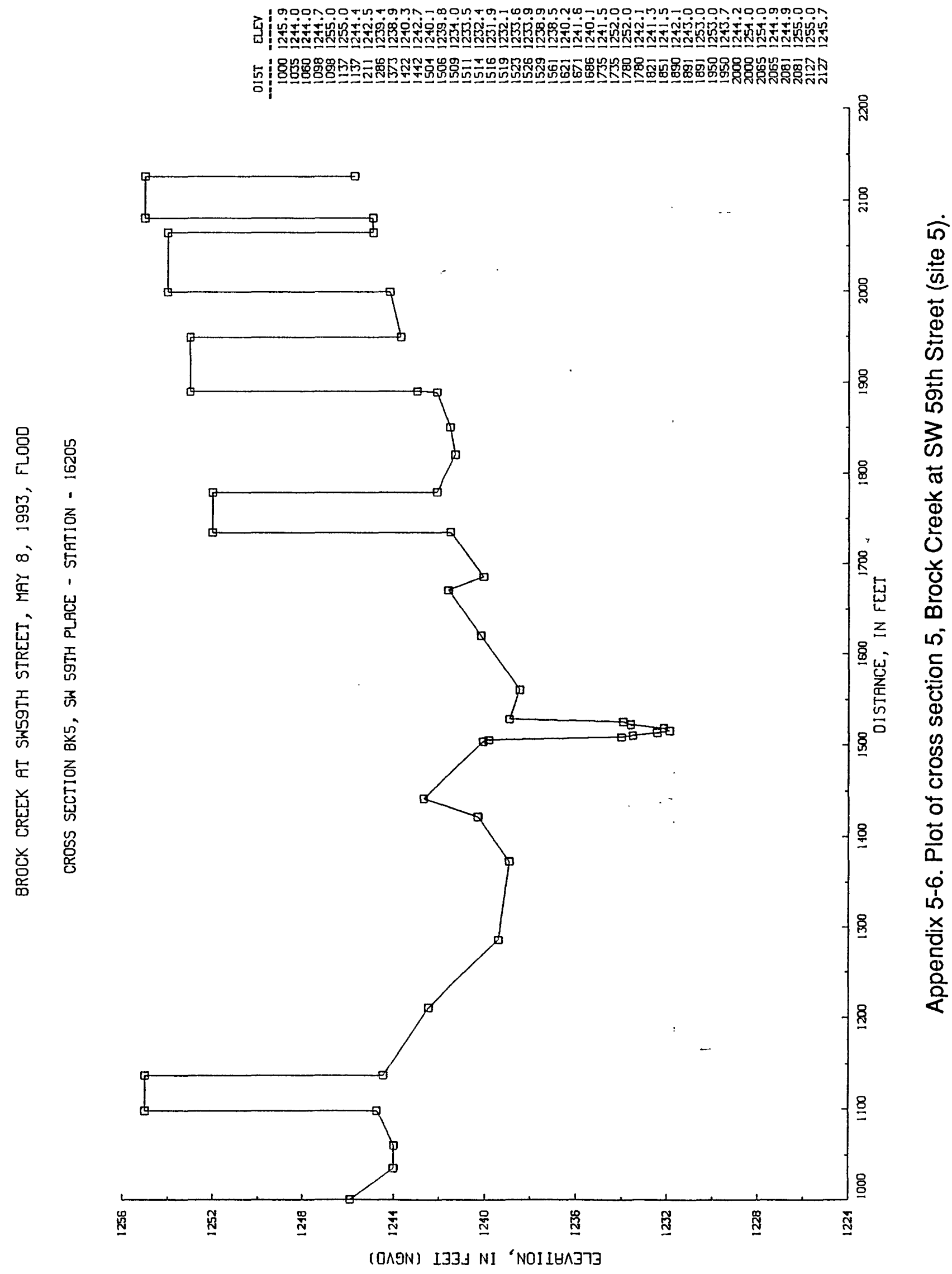


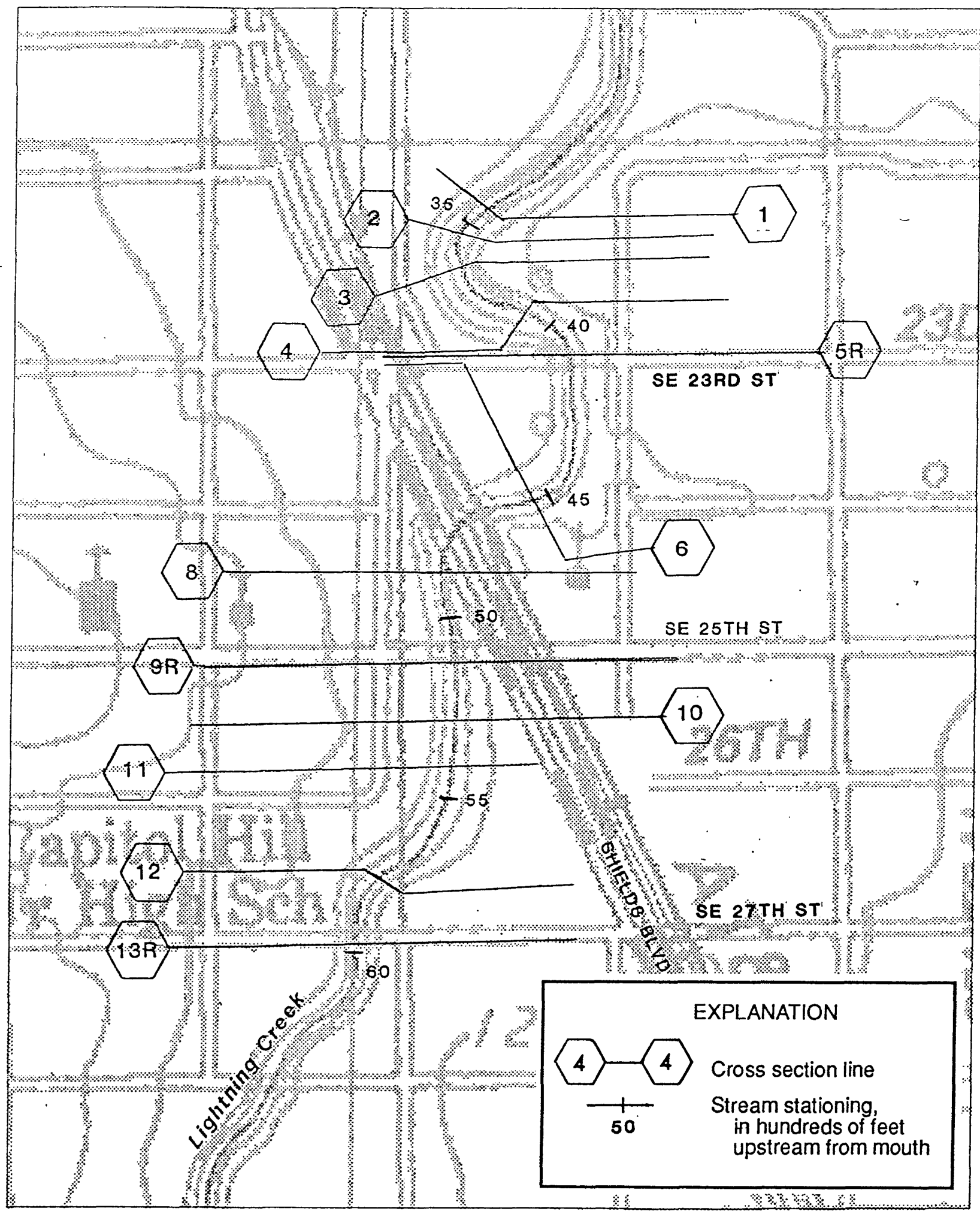

Base from U.S. Geological Survey Digital Raster Graphic, 1:24,000, 1986 Projection: Oklahoma Coordinate System, north zone (Lambert Conformal Conic) 


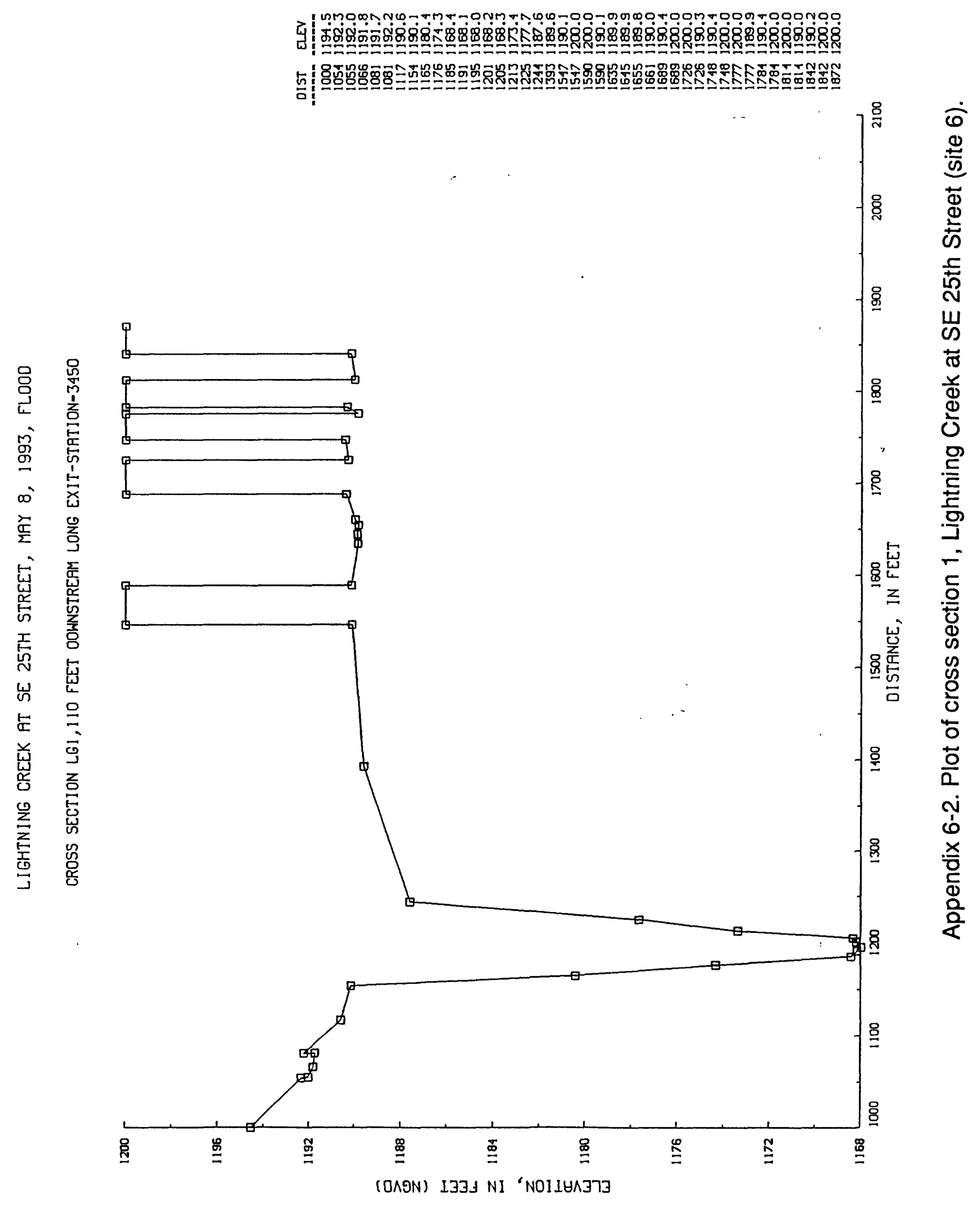




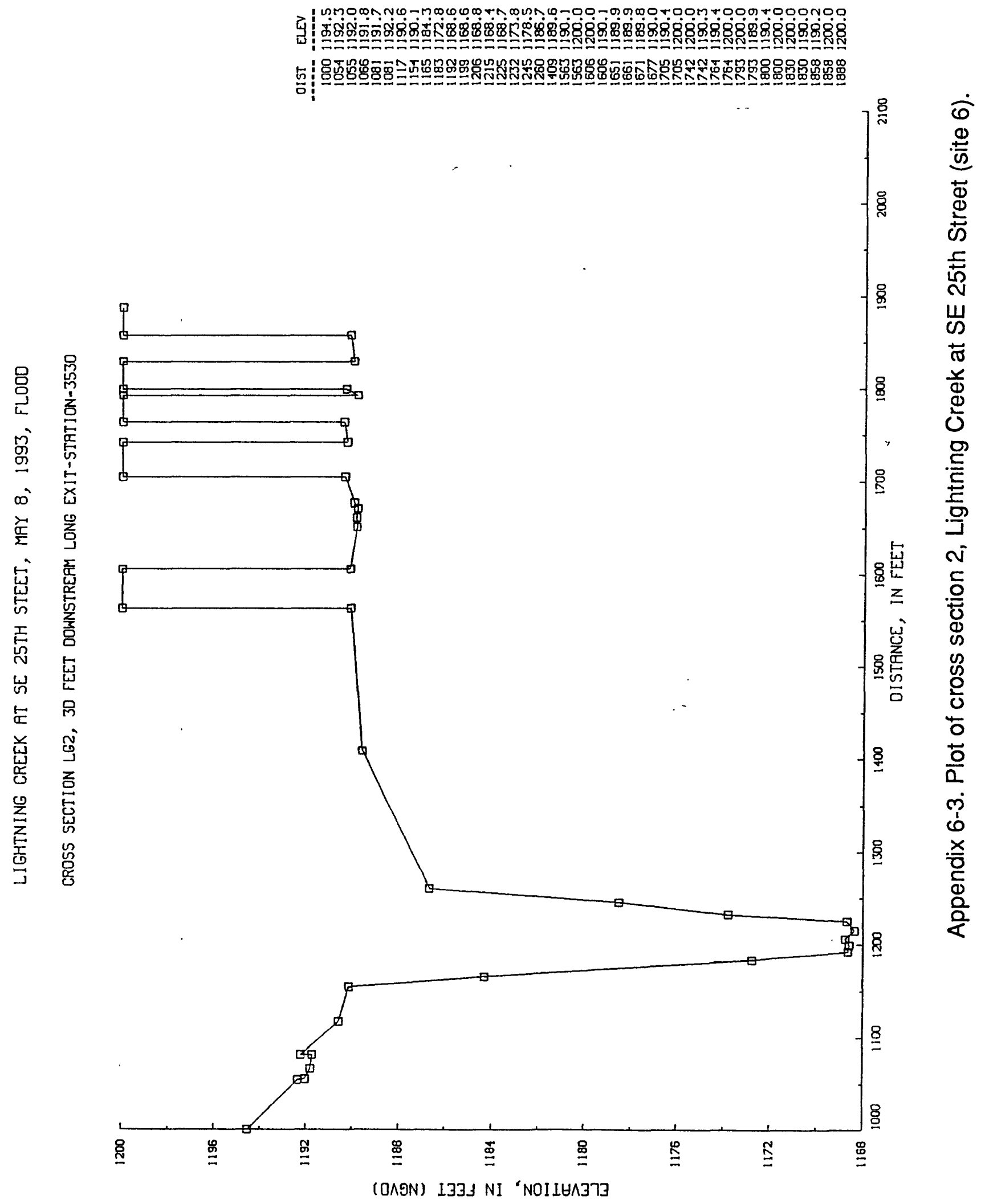




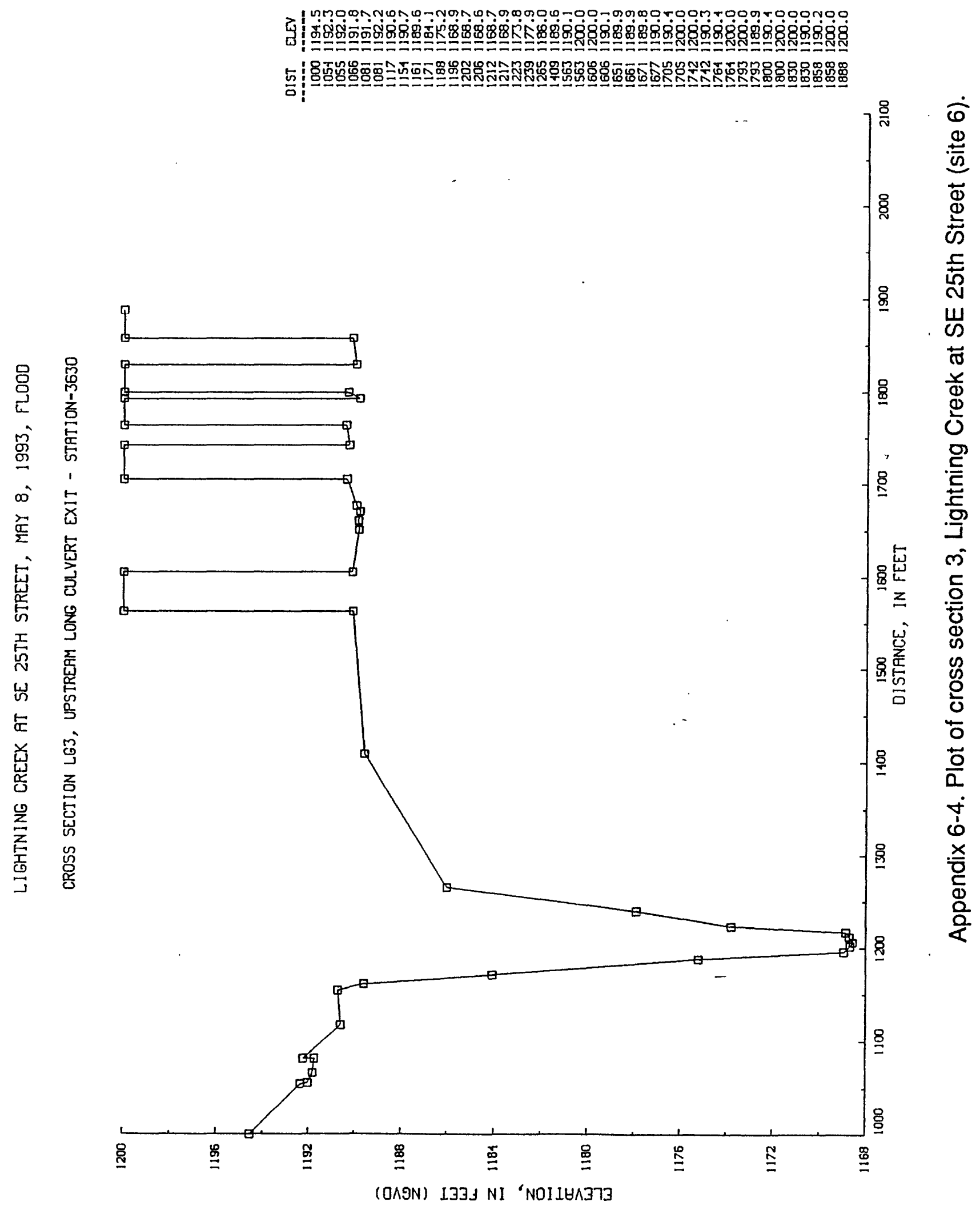




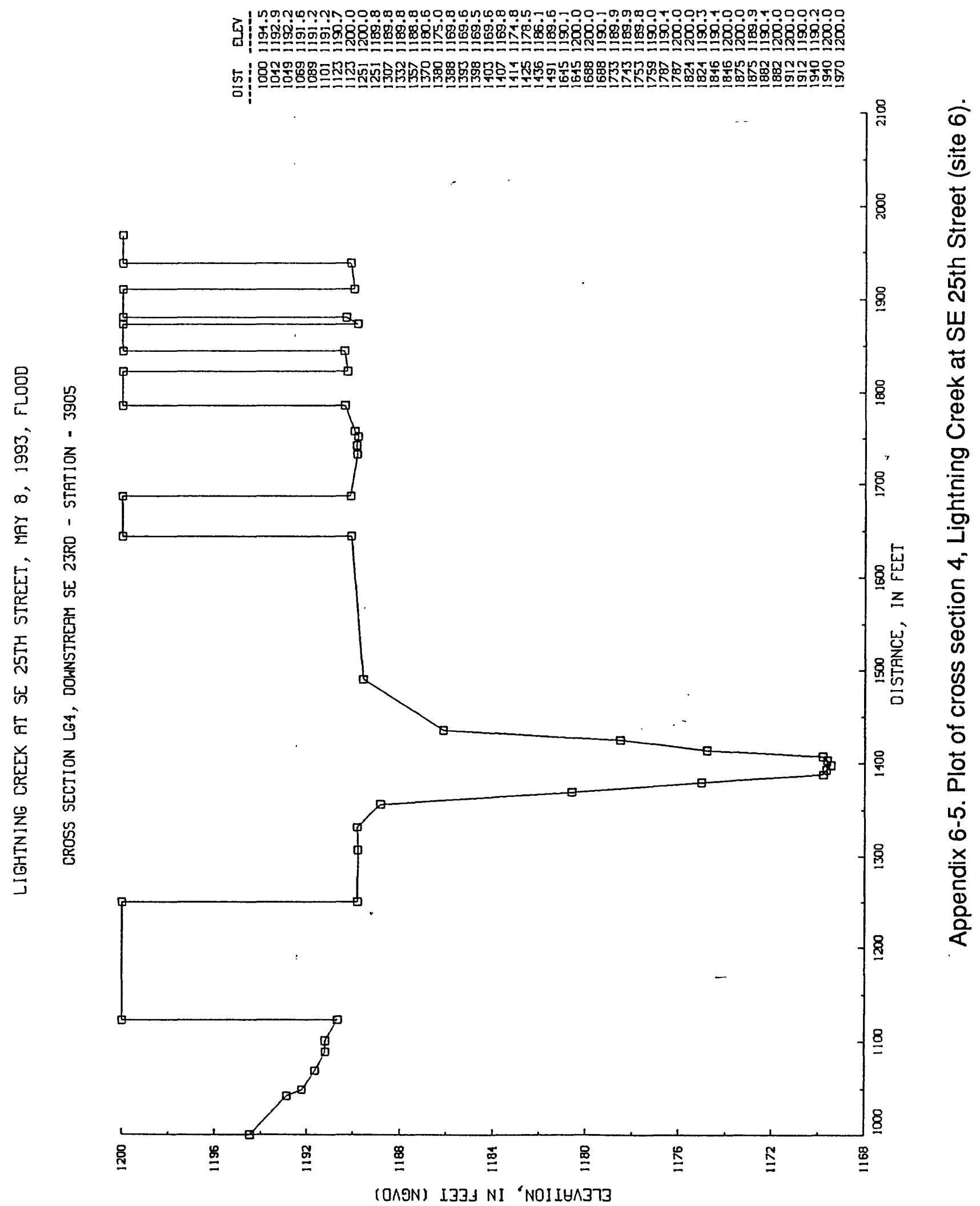




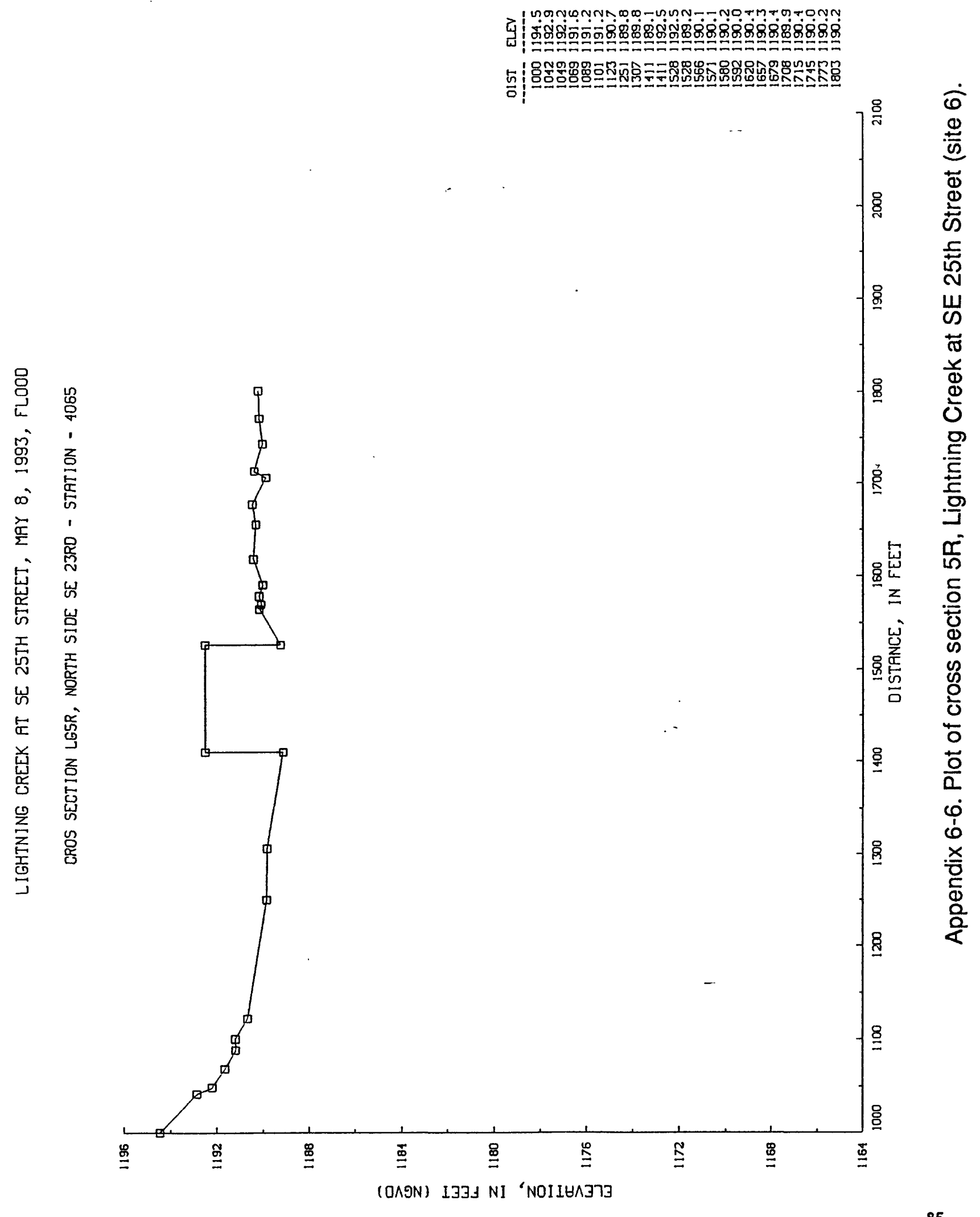




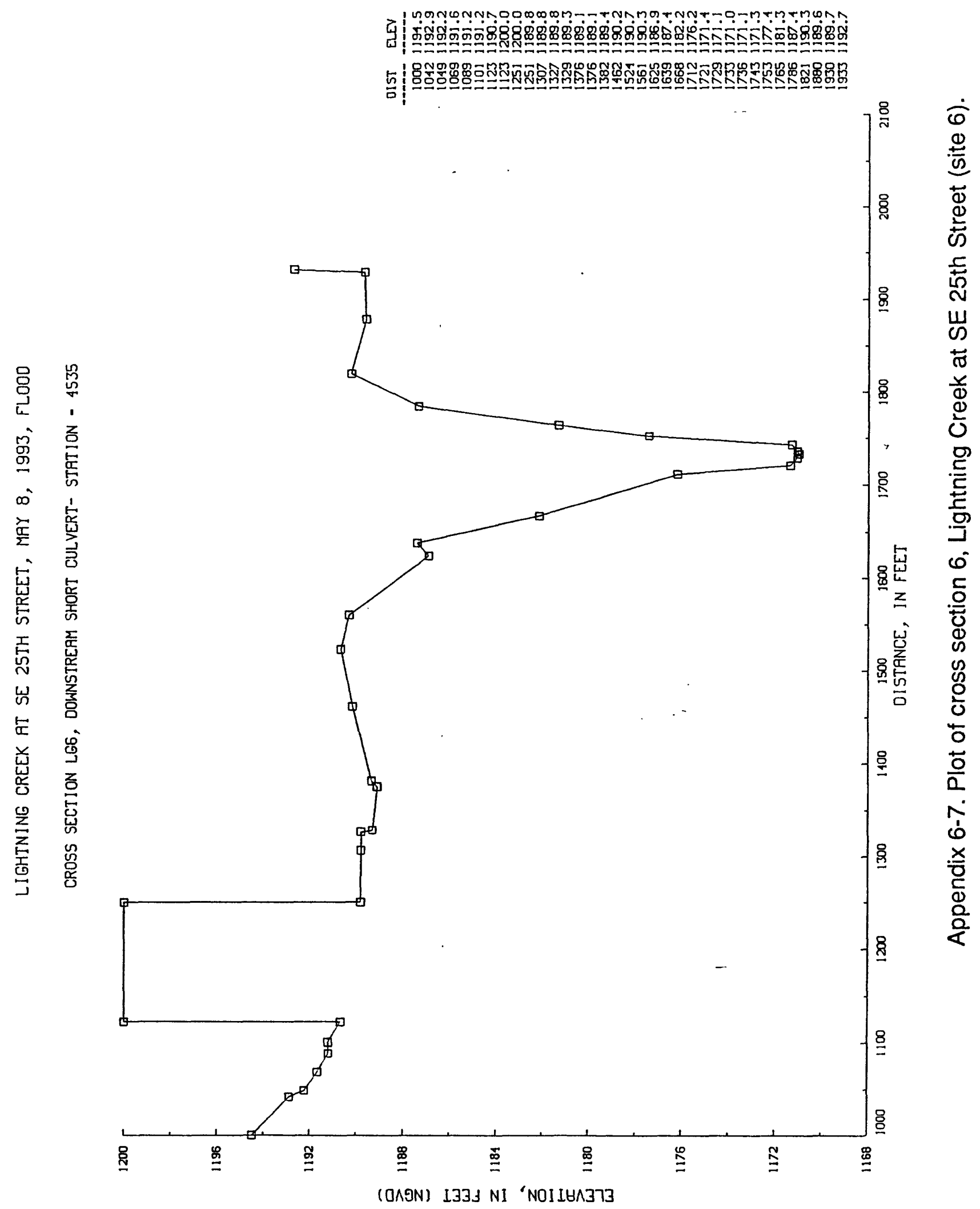




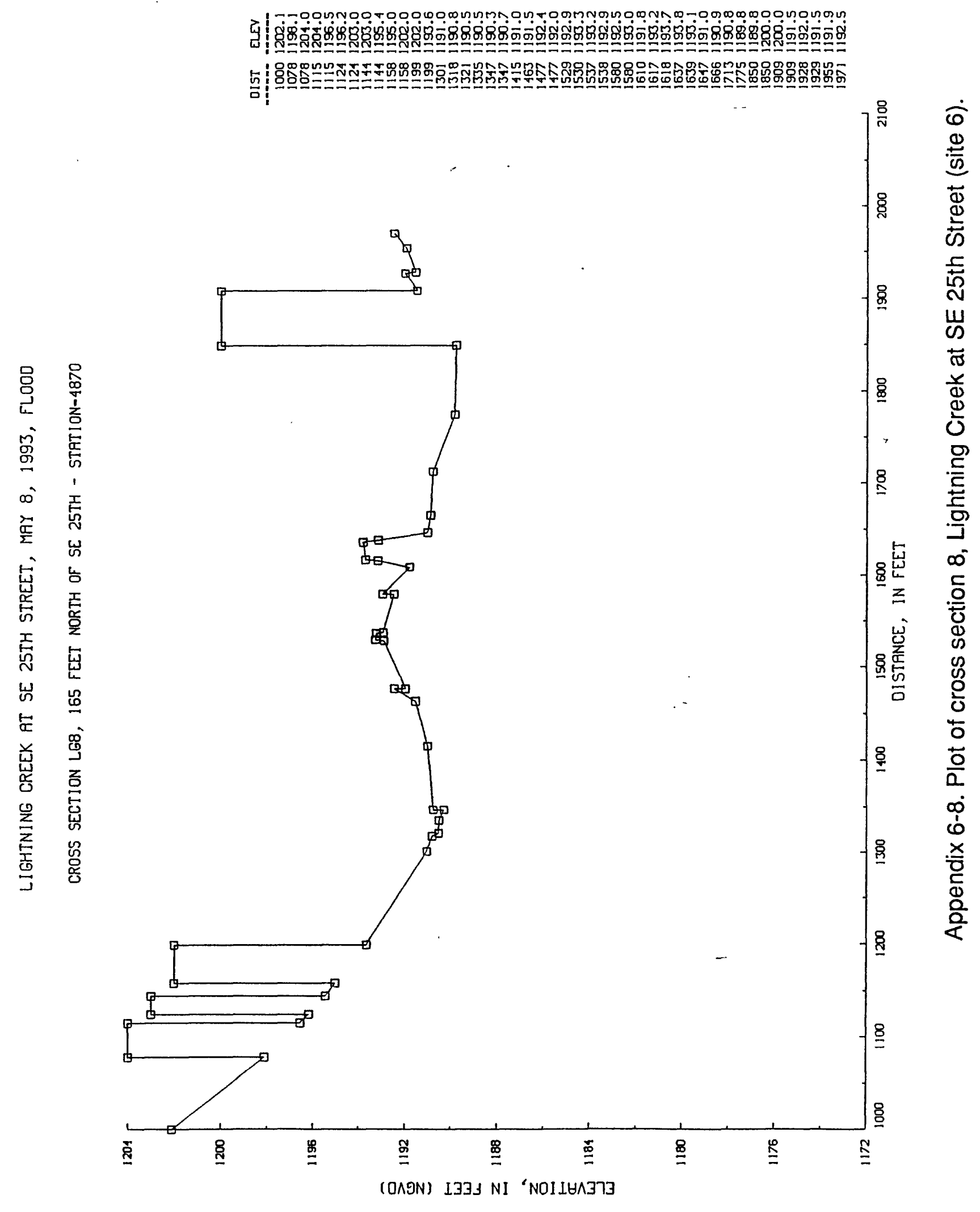




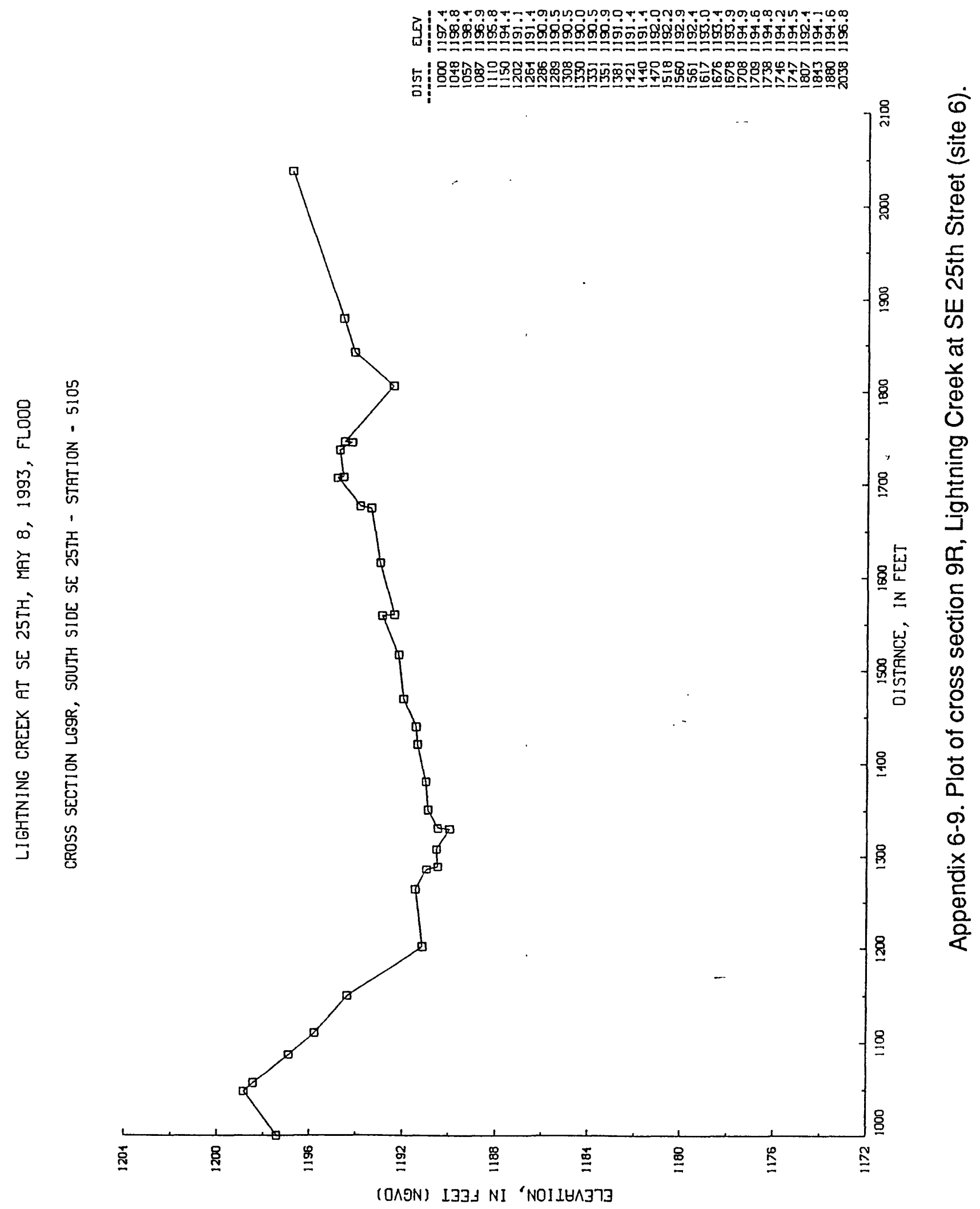




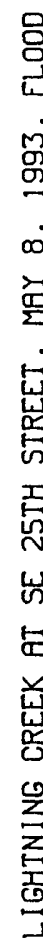

l

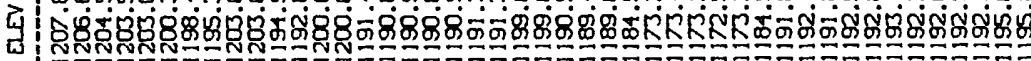

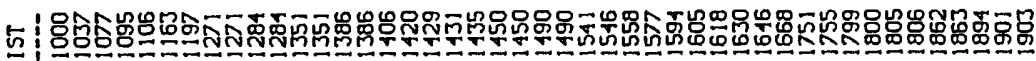

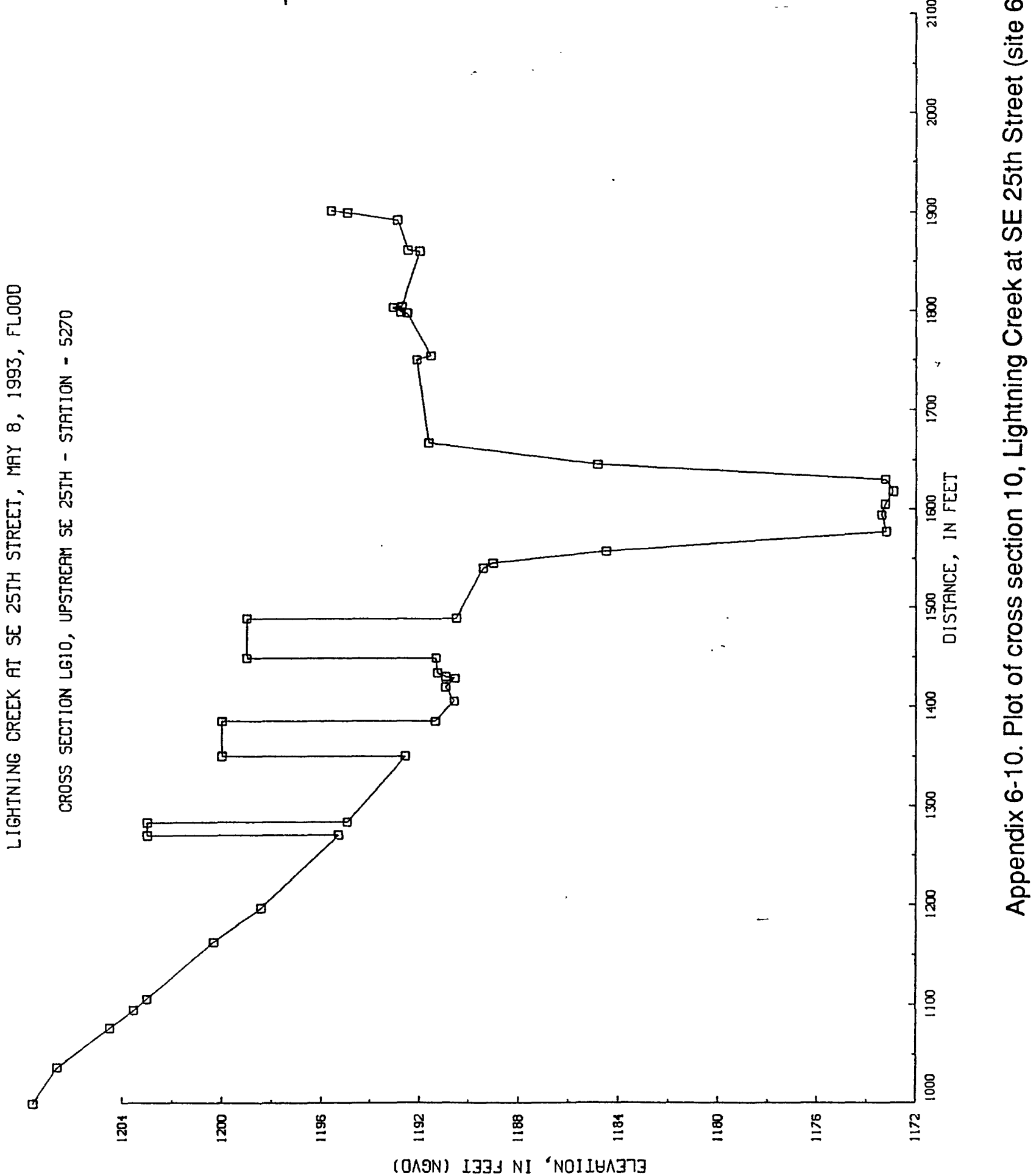




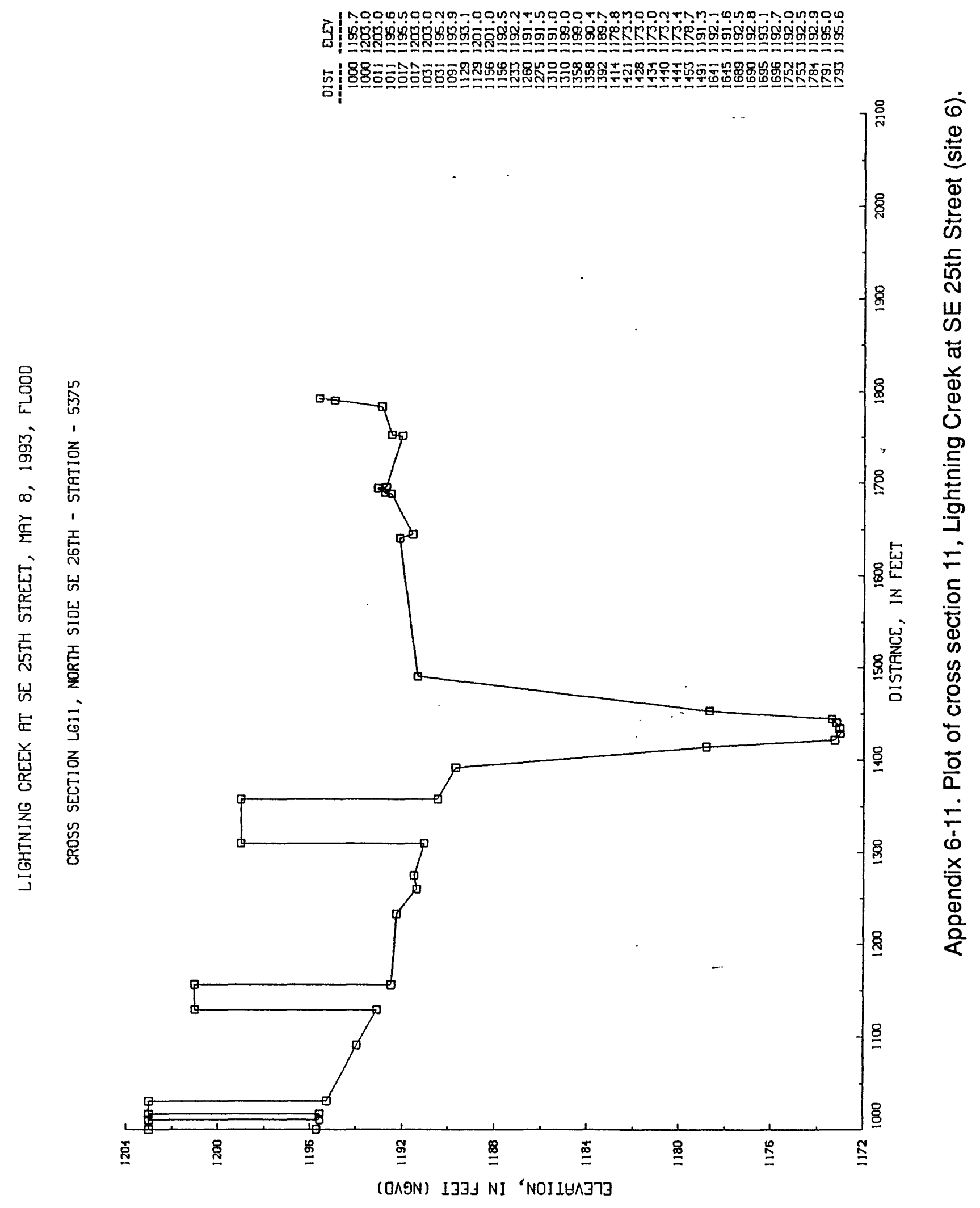




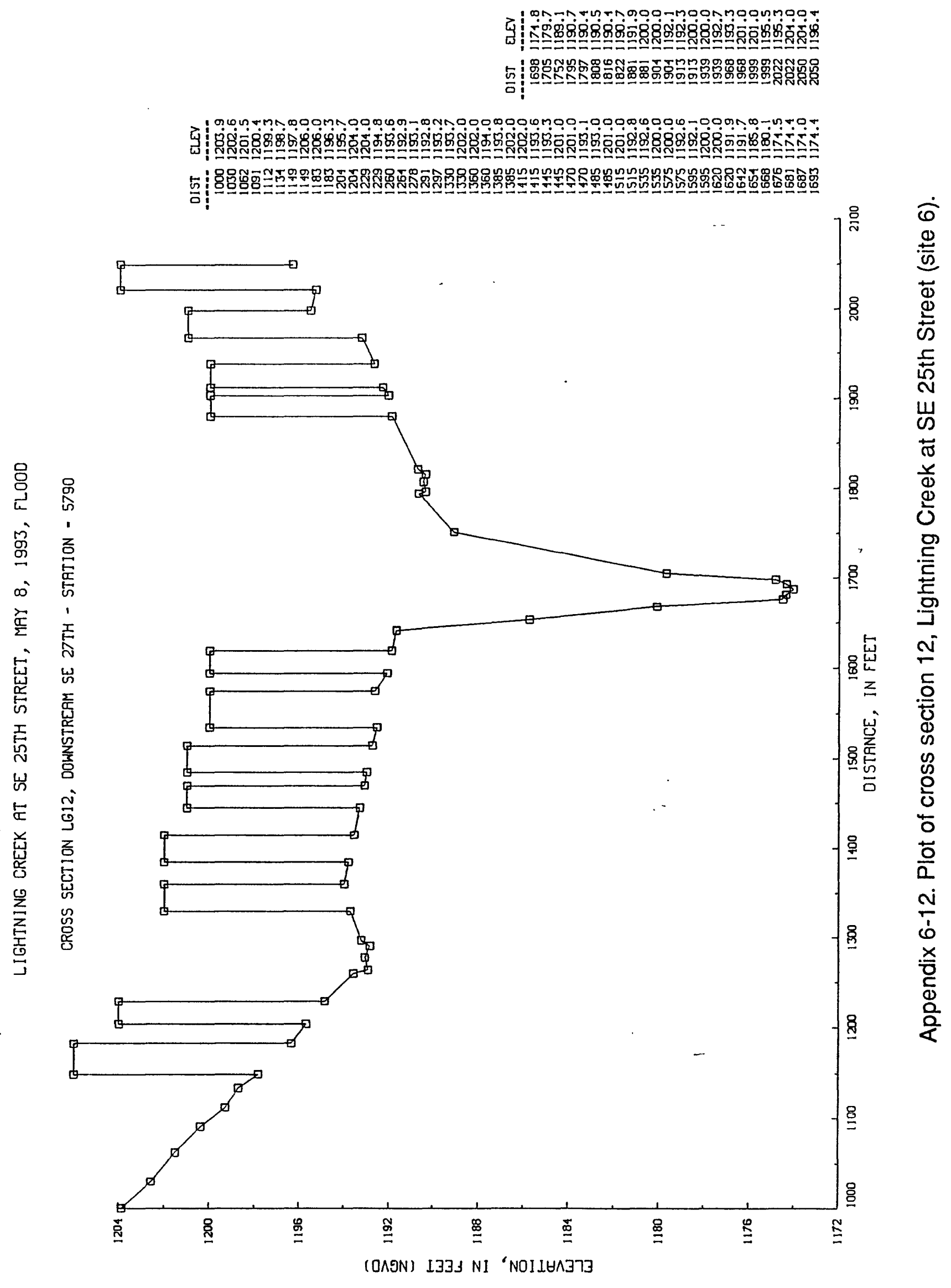




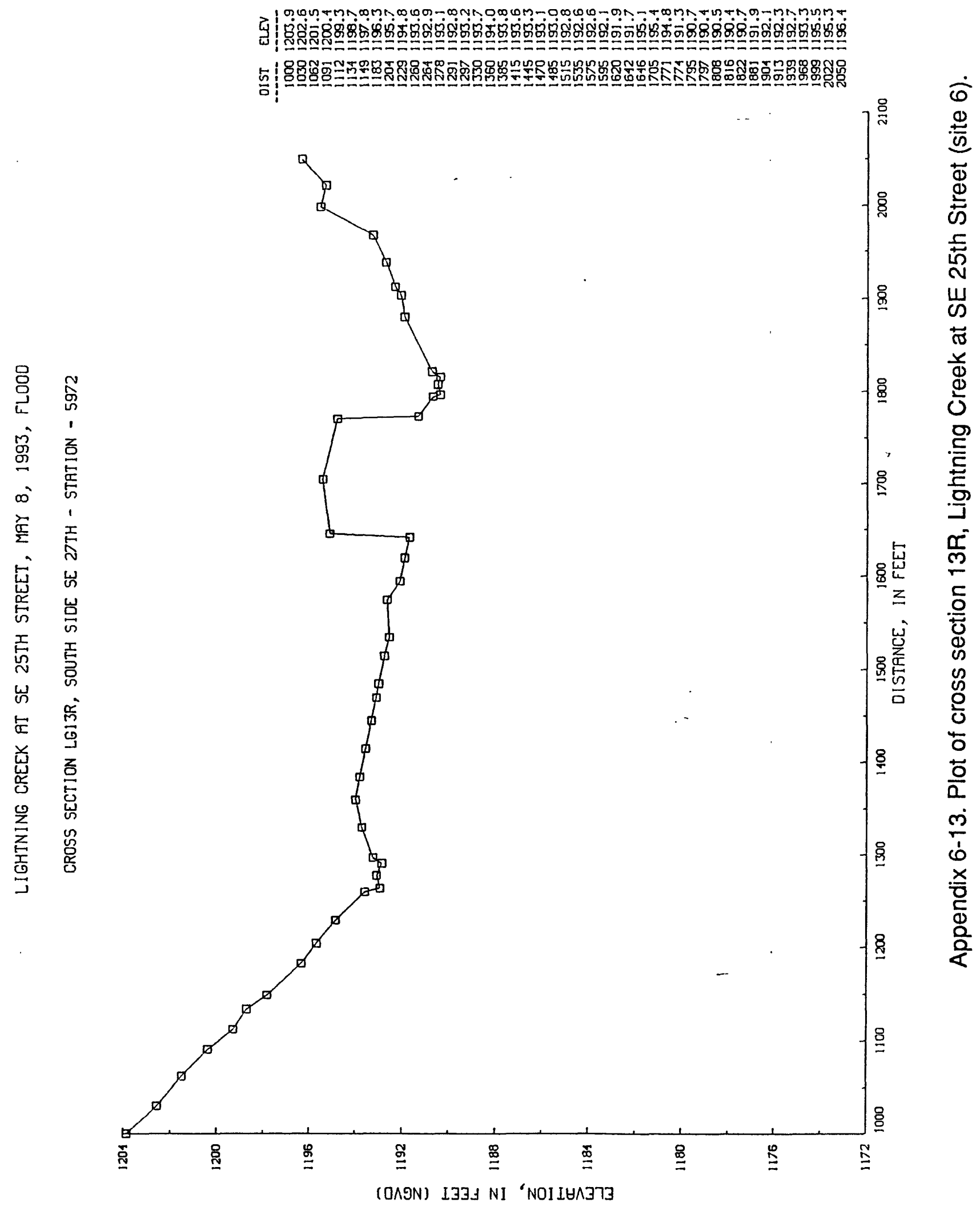




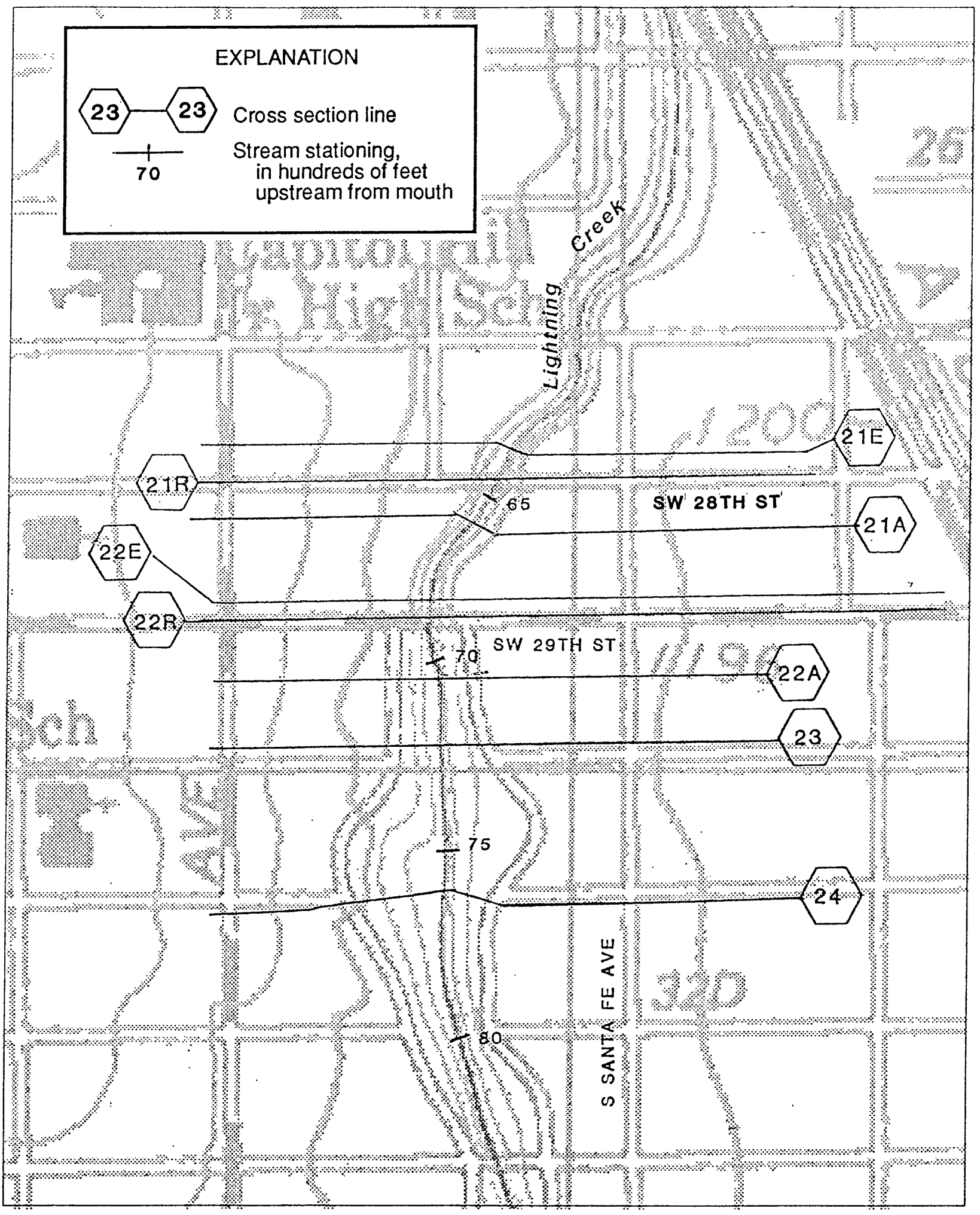

Base from U.S. Geological Survey Digital Raster Graphic, 1:24,000, 1986 Projection: Oklahoma Coordinate System, north zone (Lambert Conformal Conic)

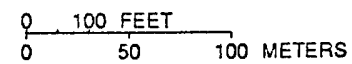

Appendix 7-1. Location of study cross sections on Lightning Creek at SW 29th Street (site 7). 


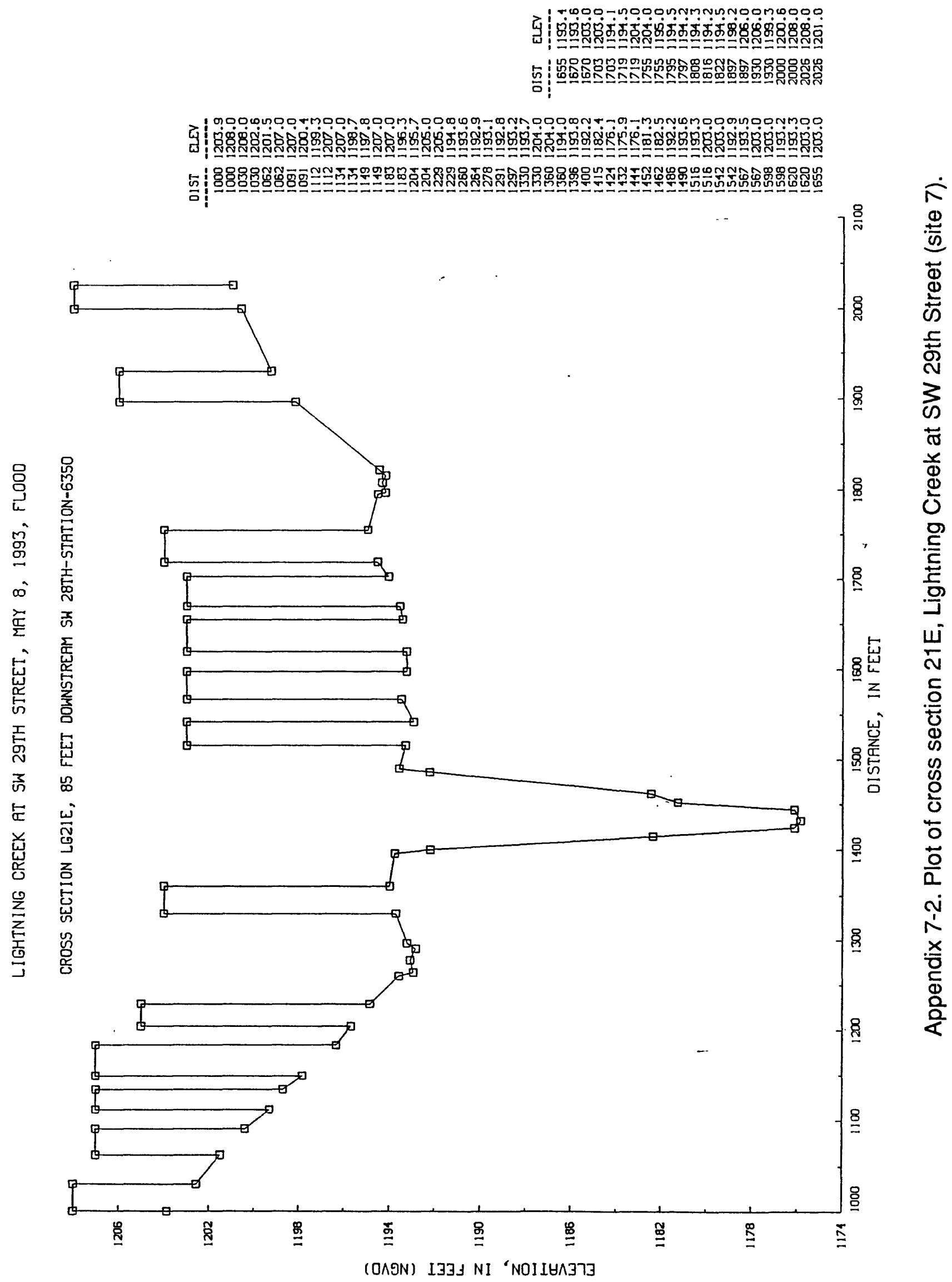




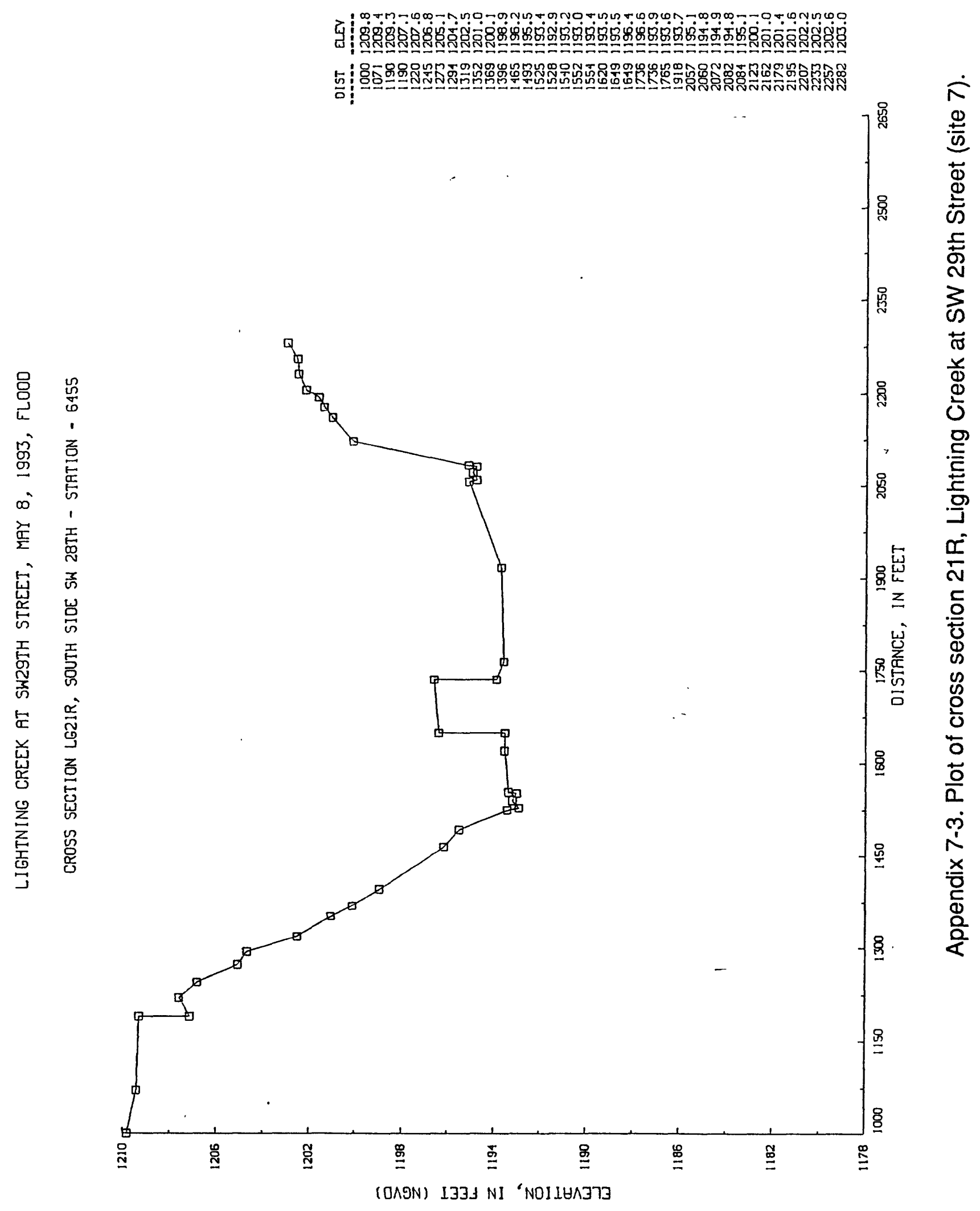




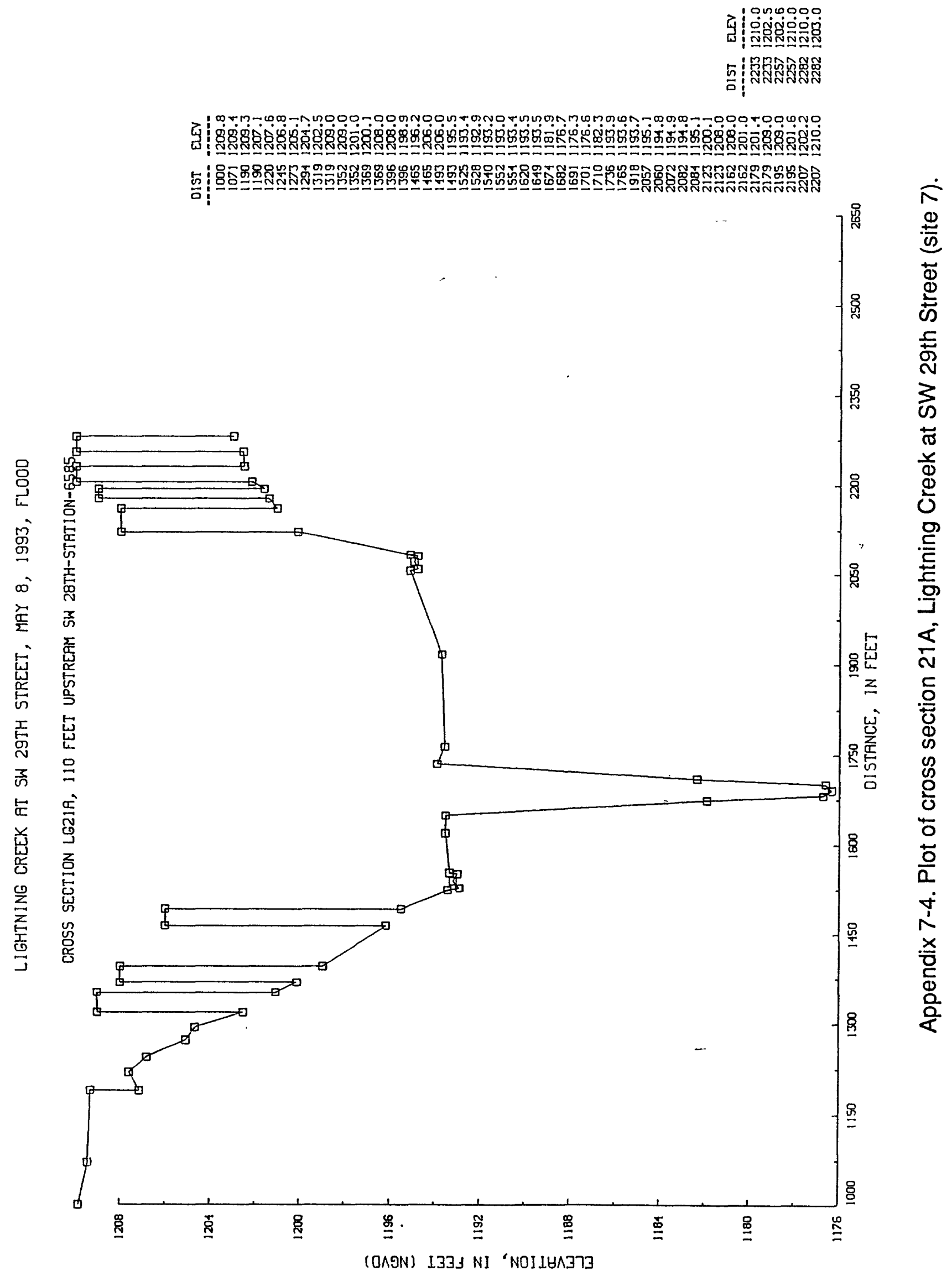




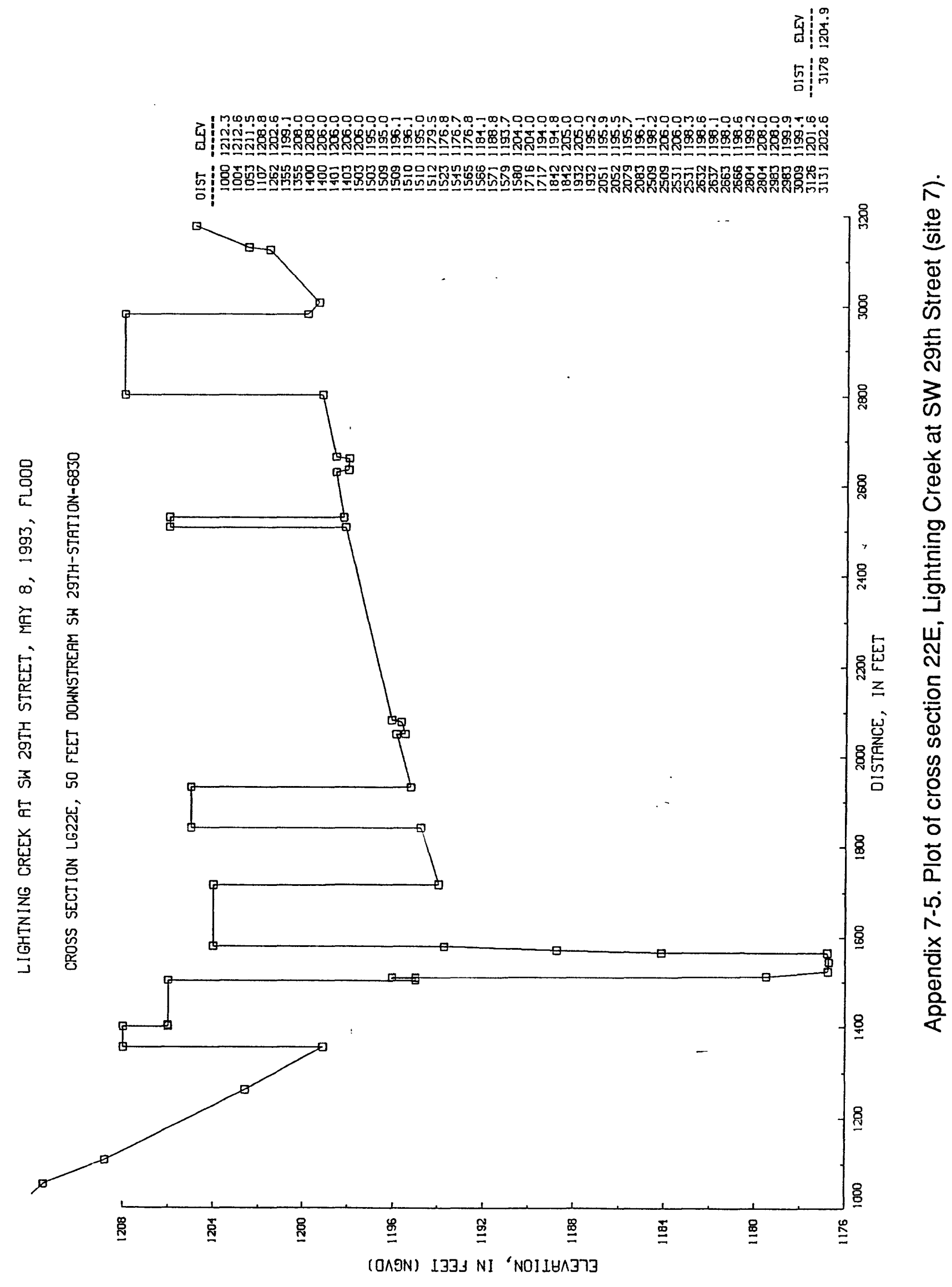




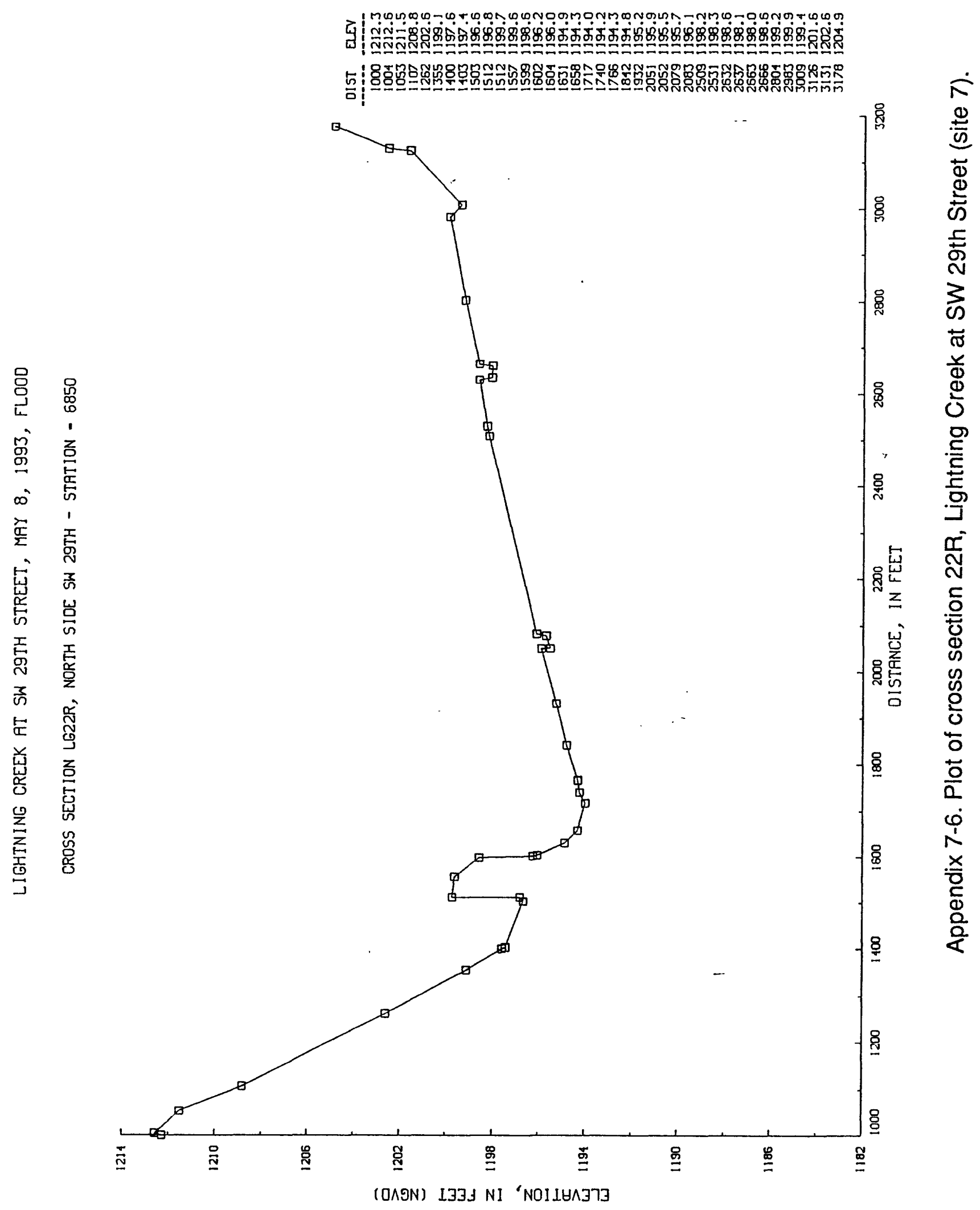




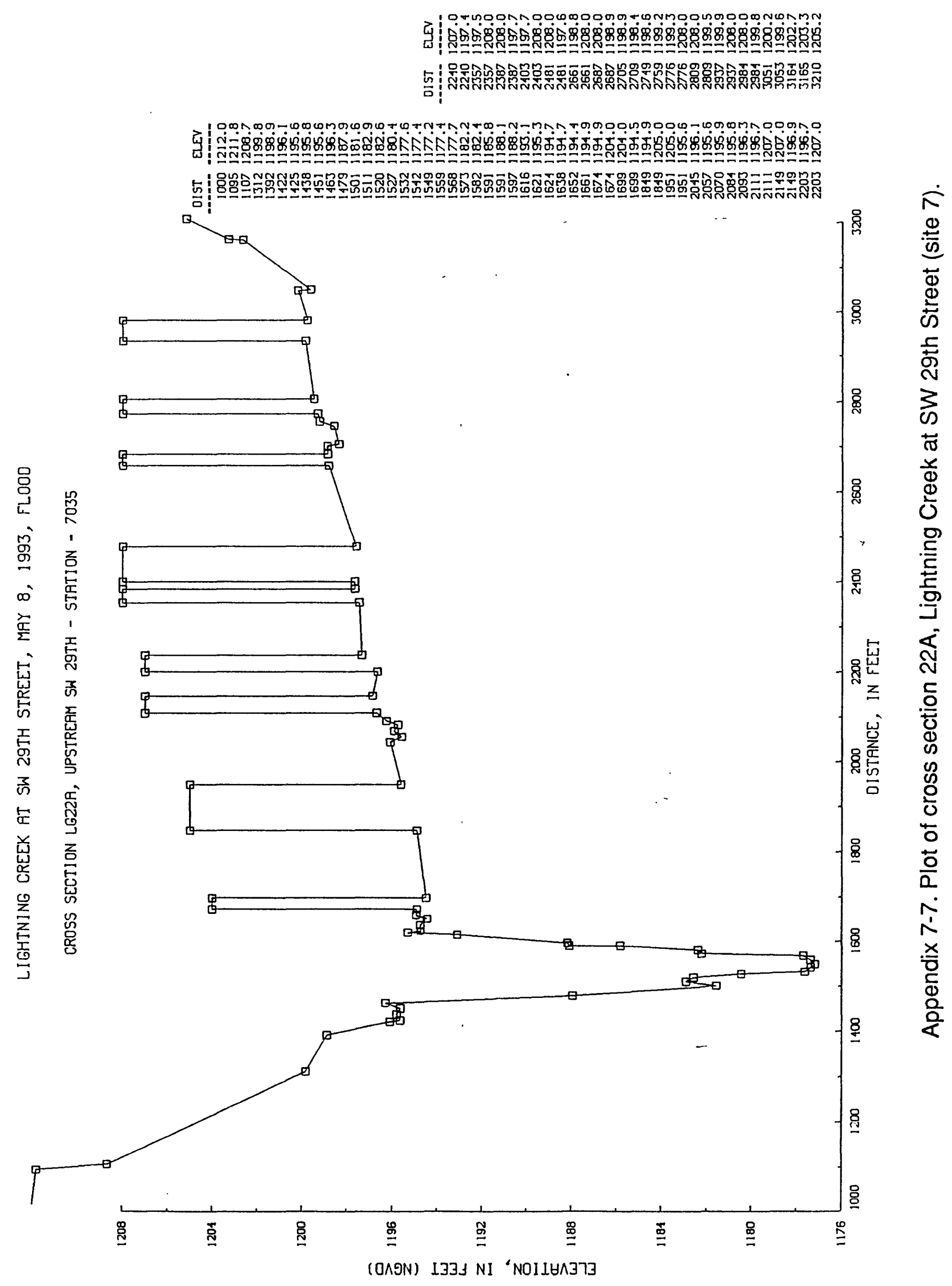




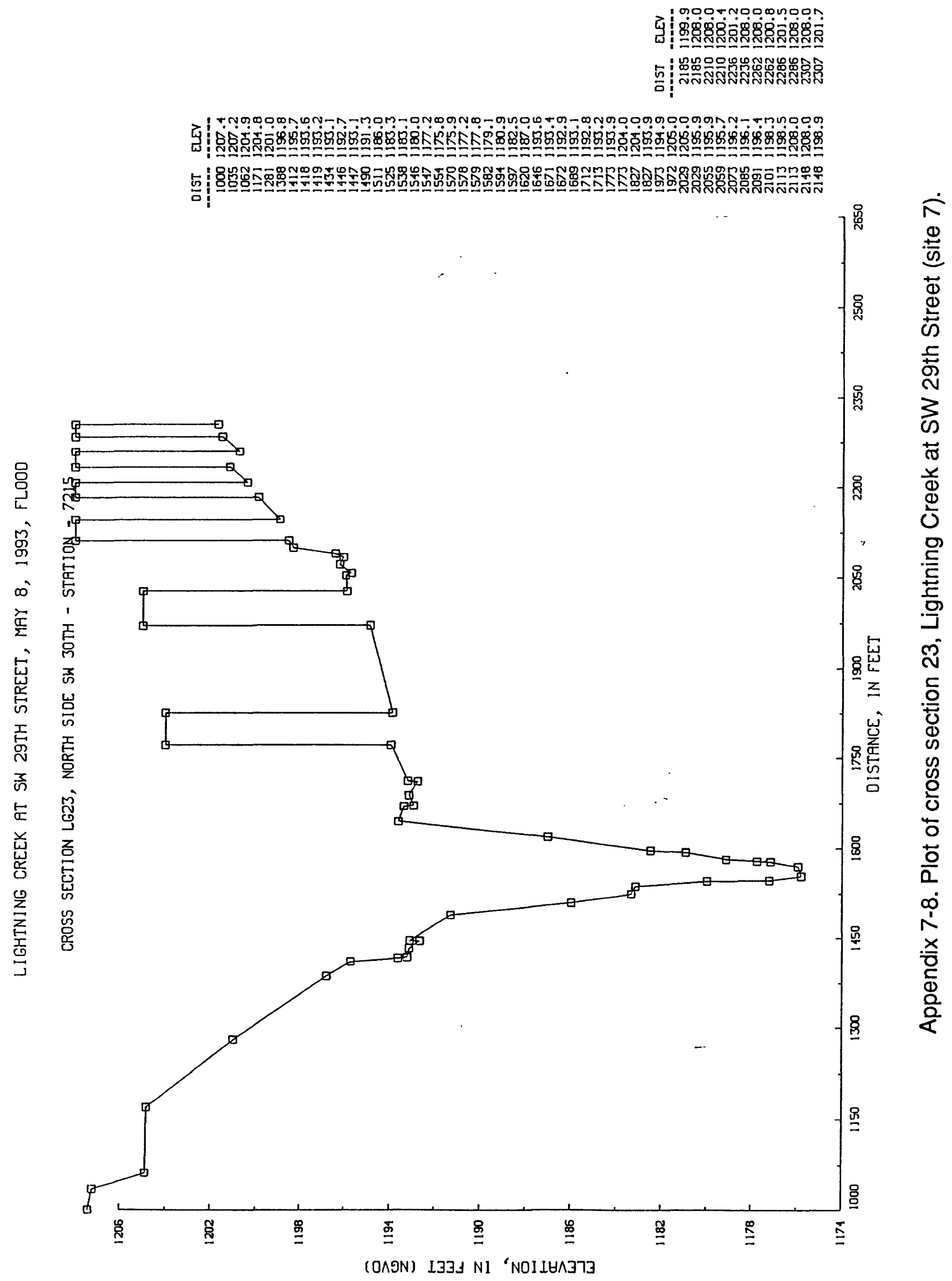




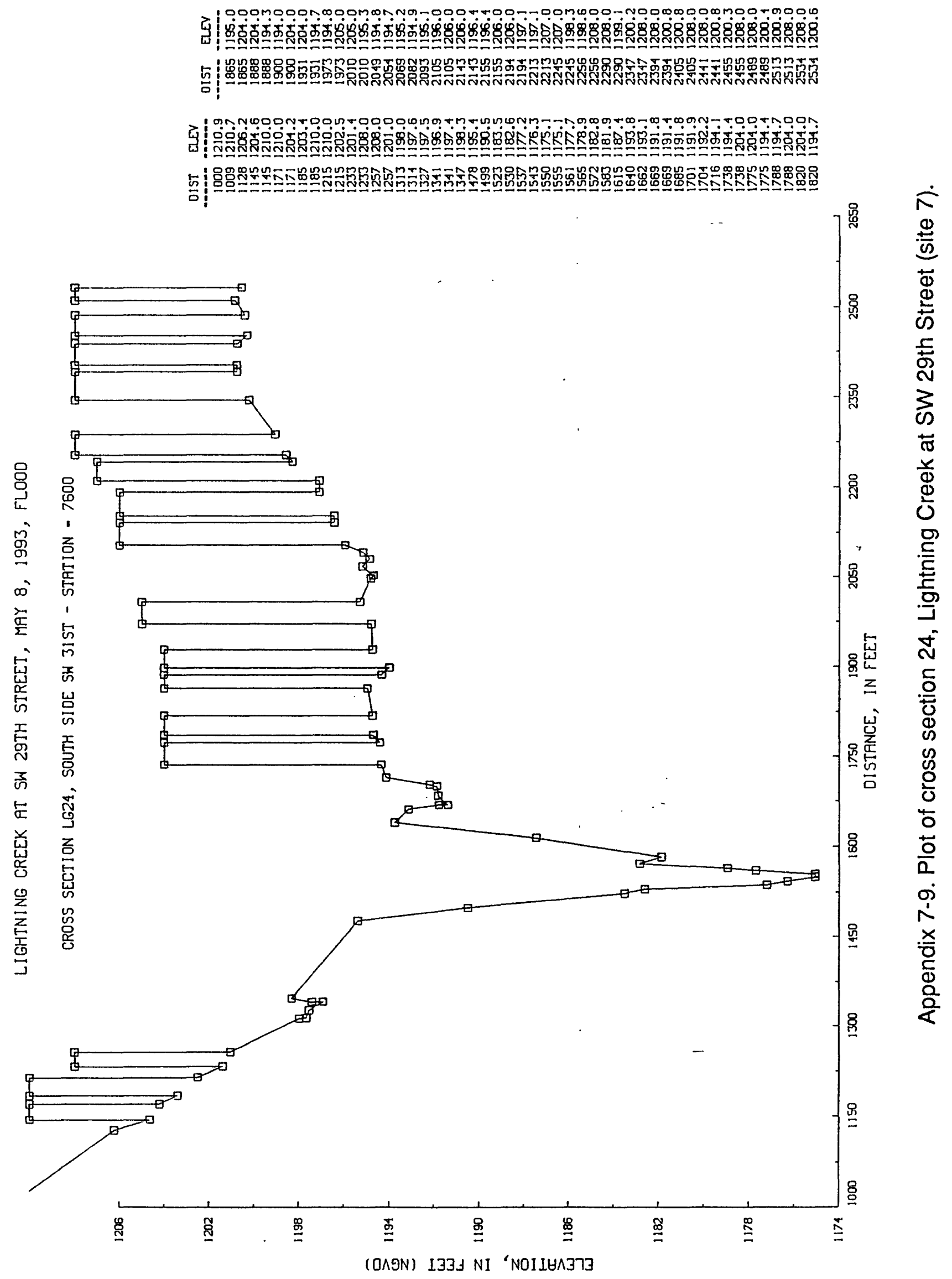




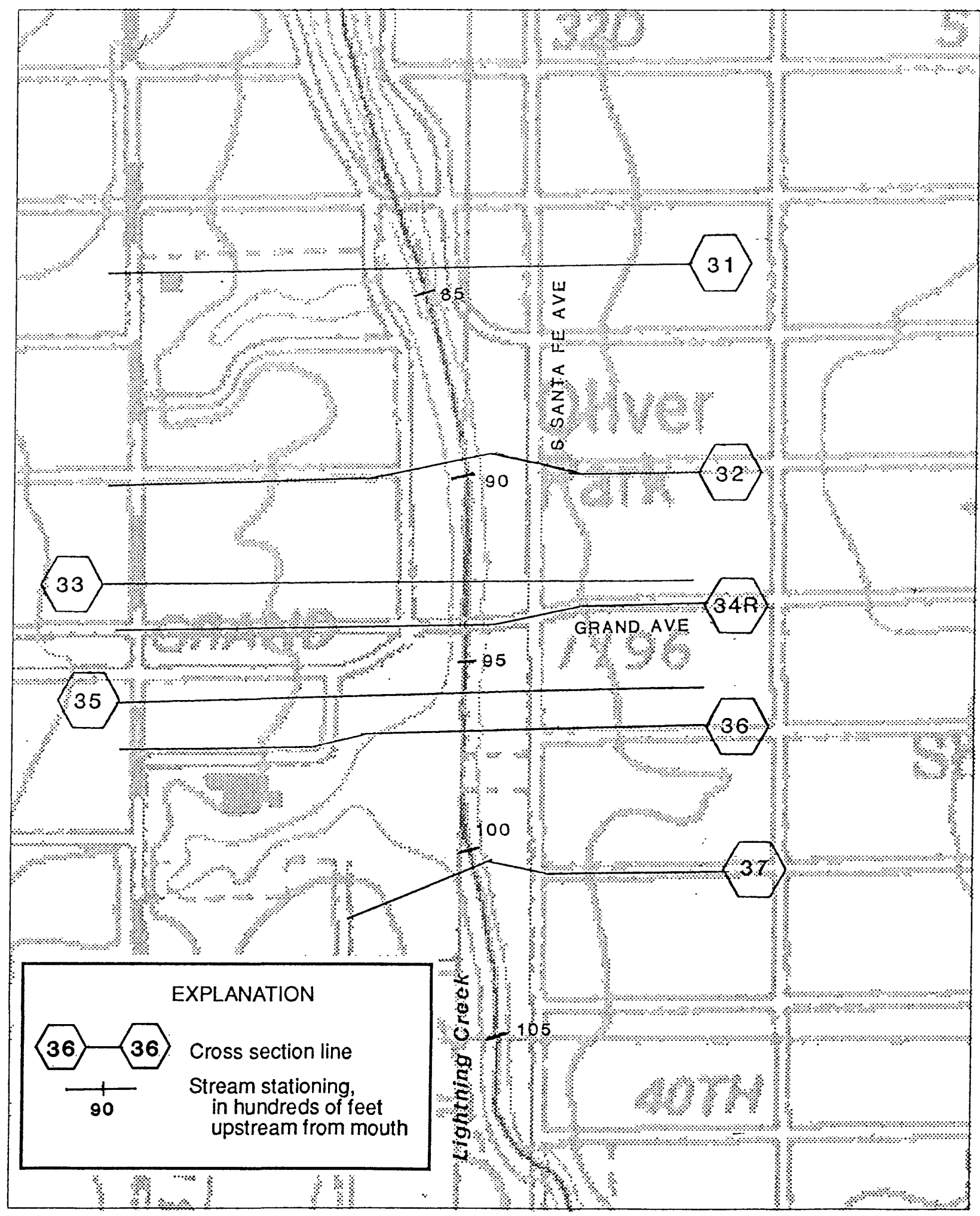

Base from U.S. Geological Survey Digital Raster Graphic, 1:24,000, 1986

Projection: Oklahoma Coordinate System, north zone (Lambert Conformal Conic)

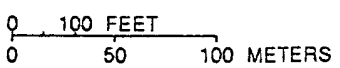

Appendix 8-1. Location of study cross sections on Lightning Creek at Grand Avenue (site 8). 


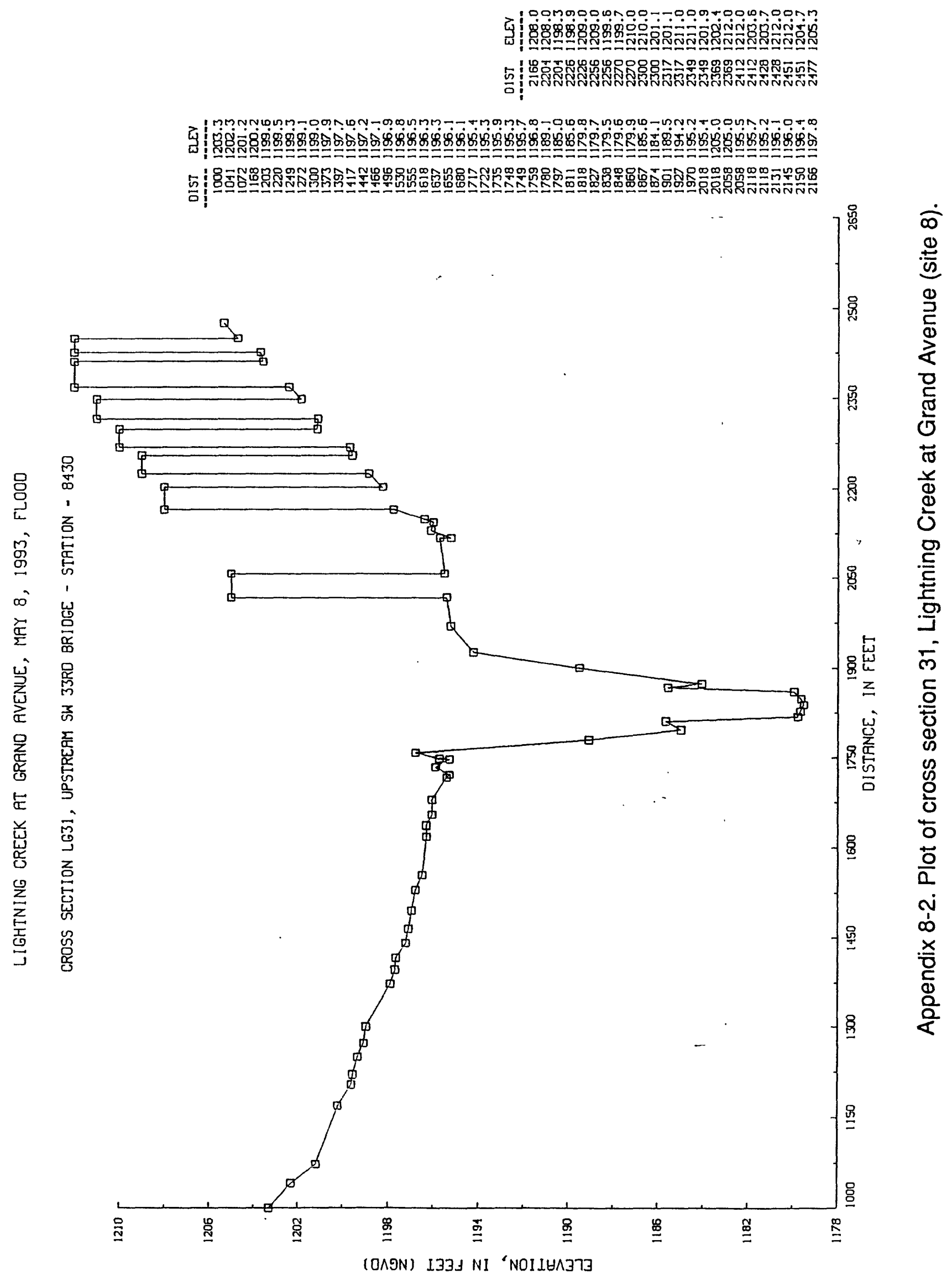




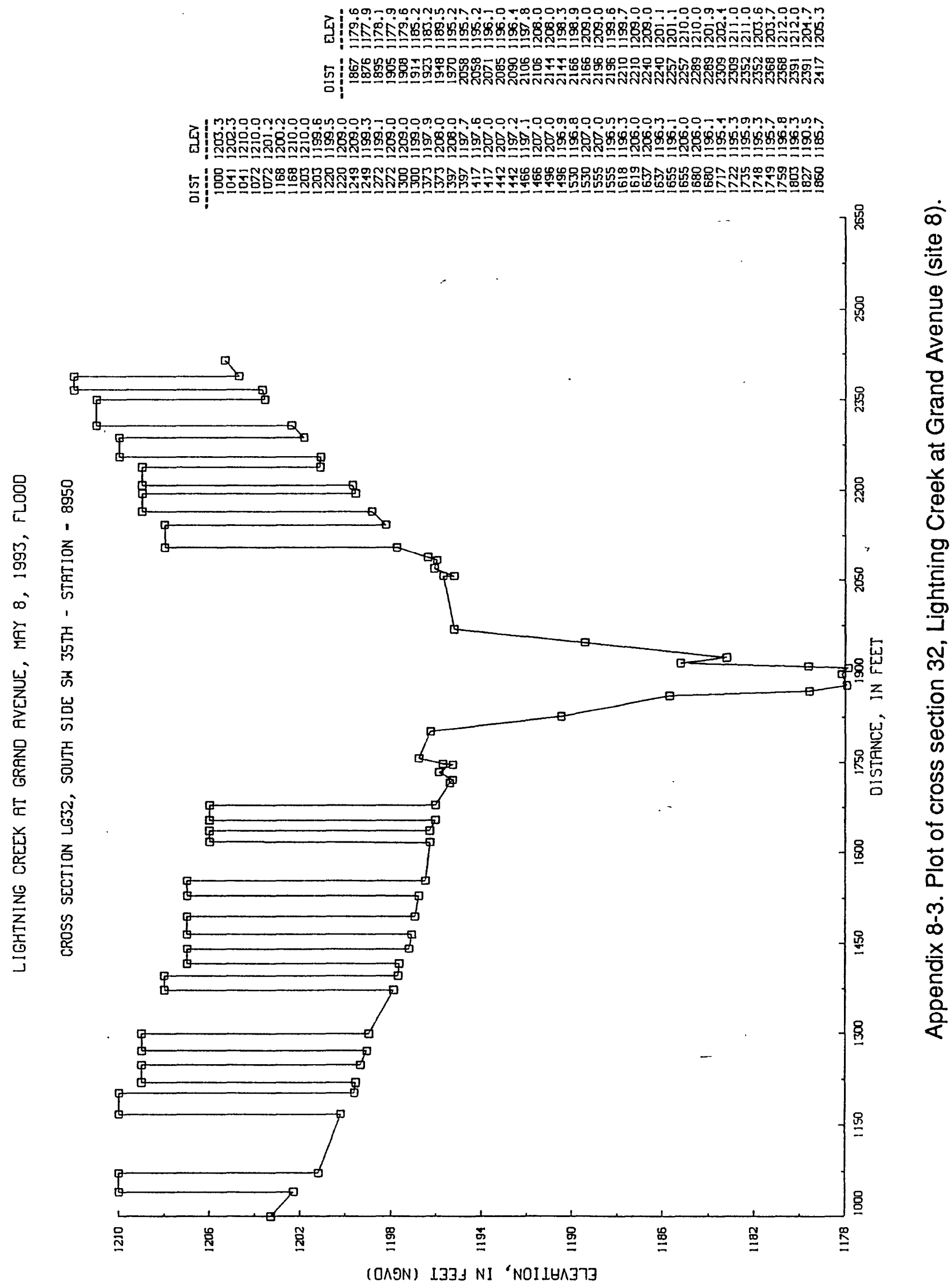




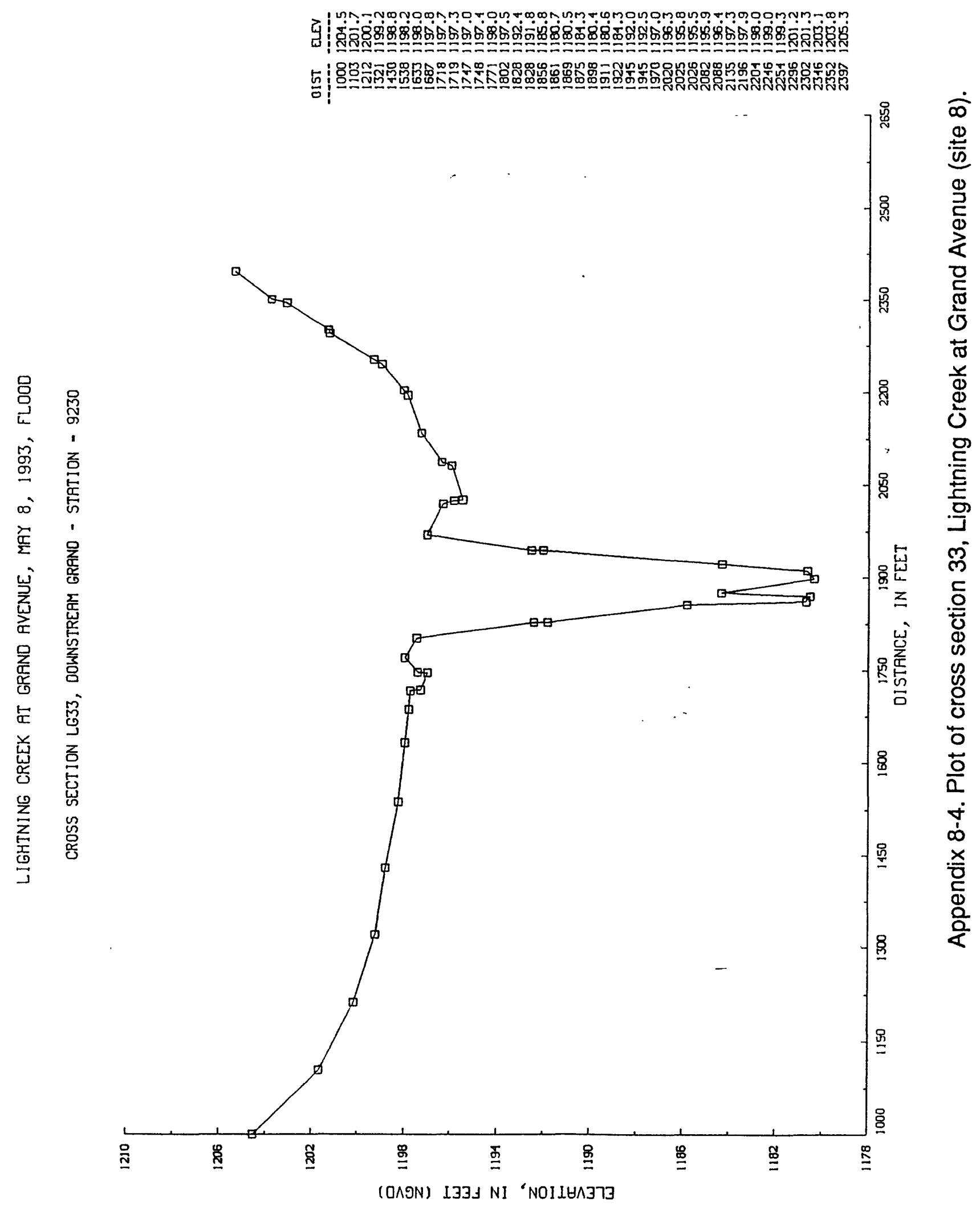




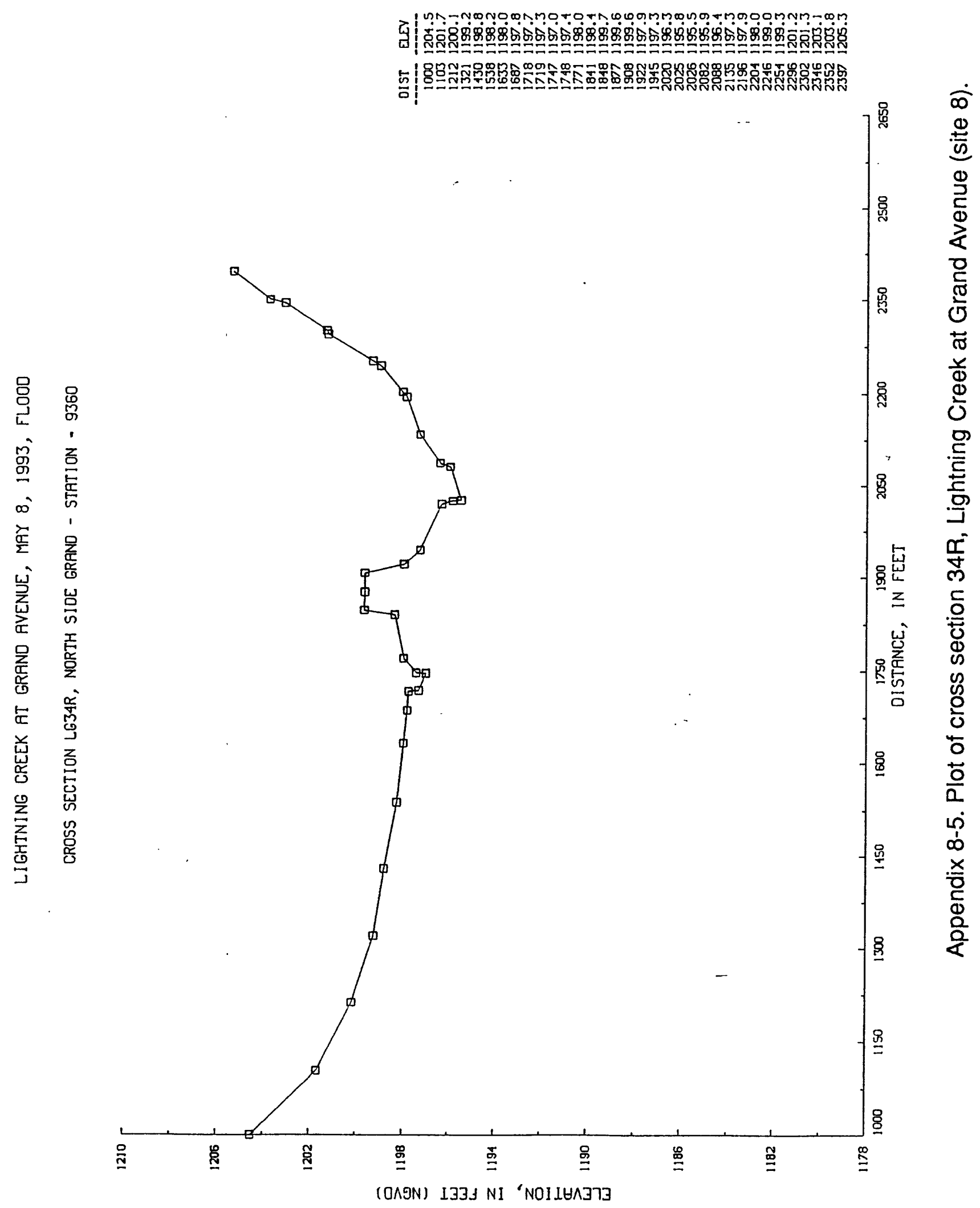




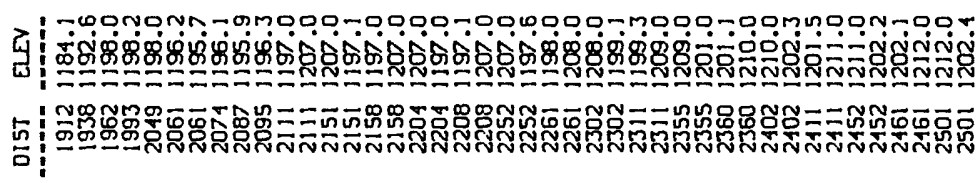

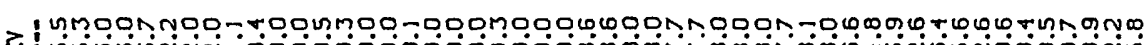

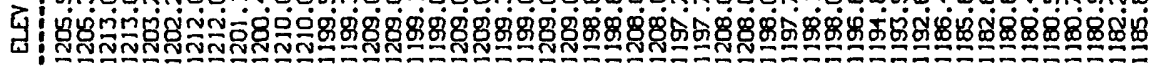
占:

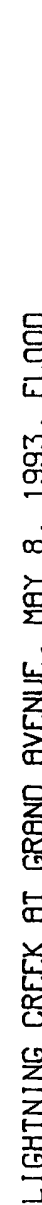
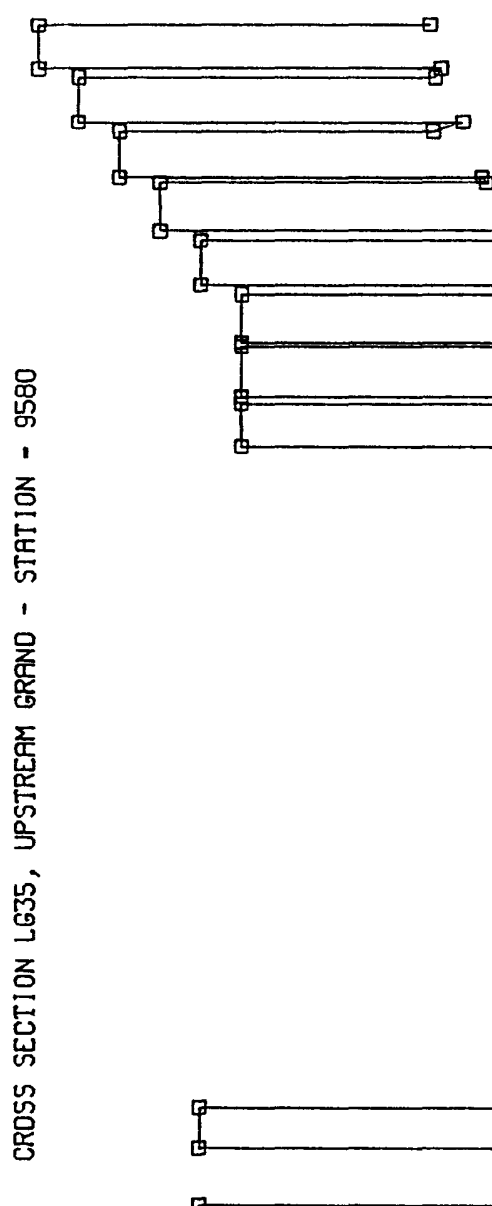

,
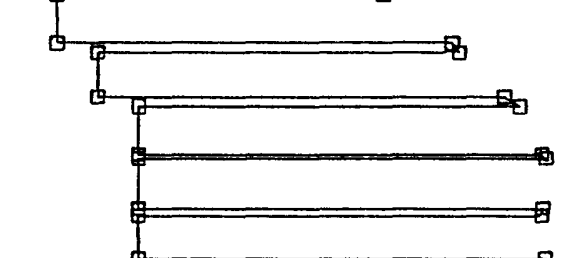<smiles>[I-]</smiles>

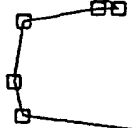

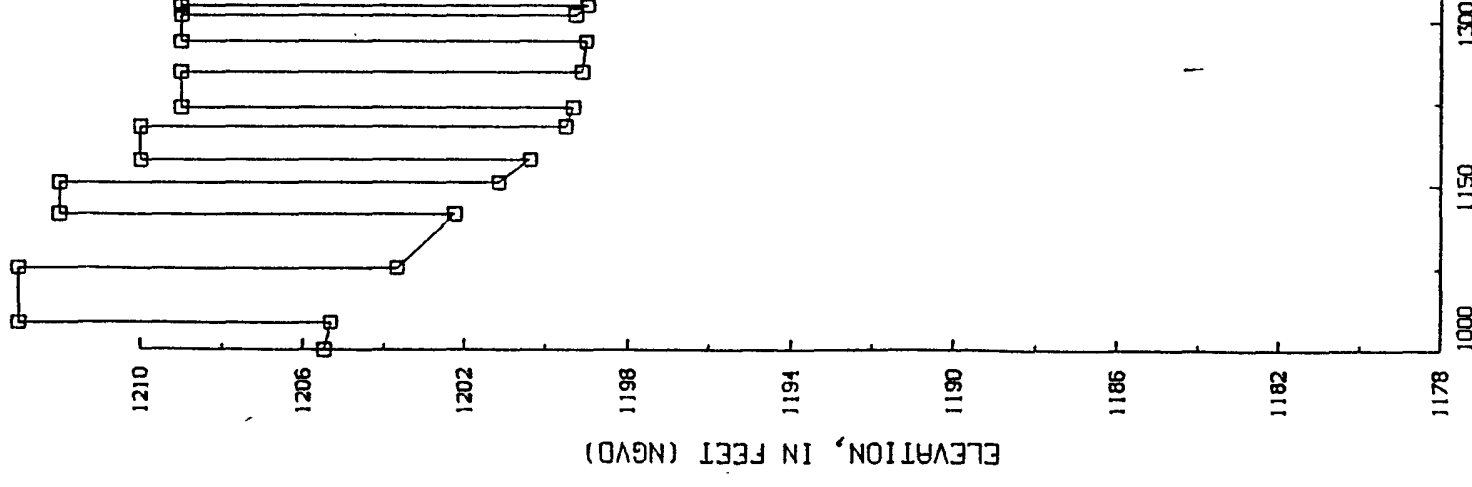




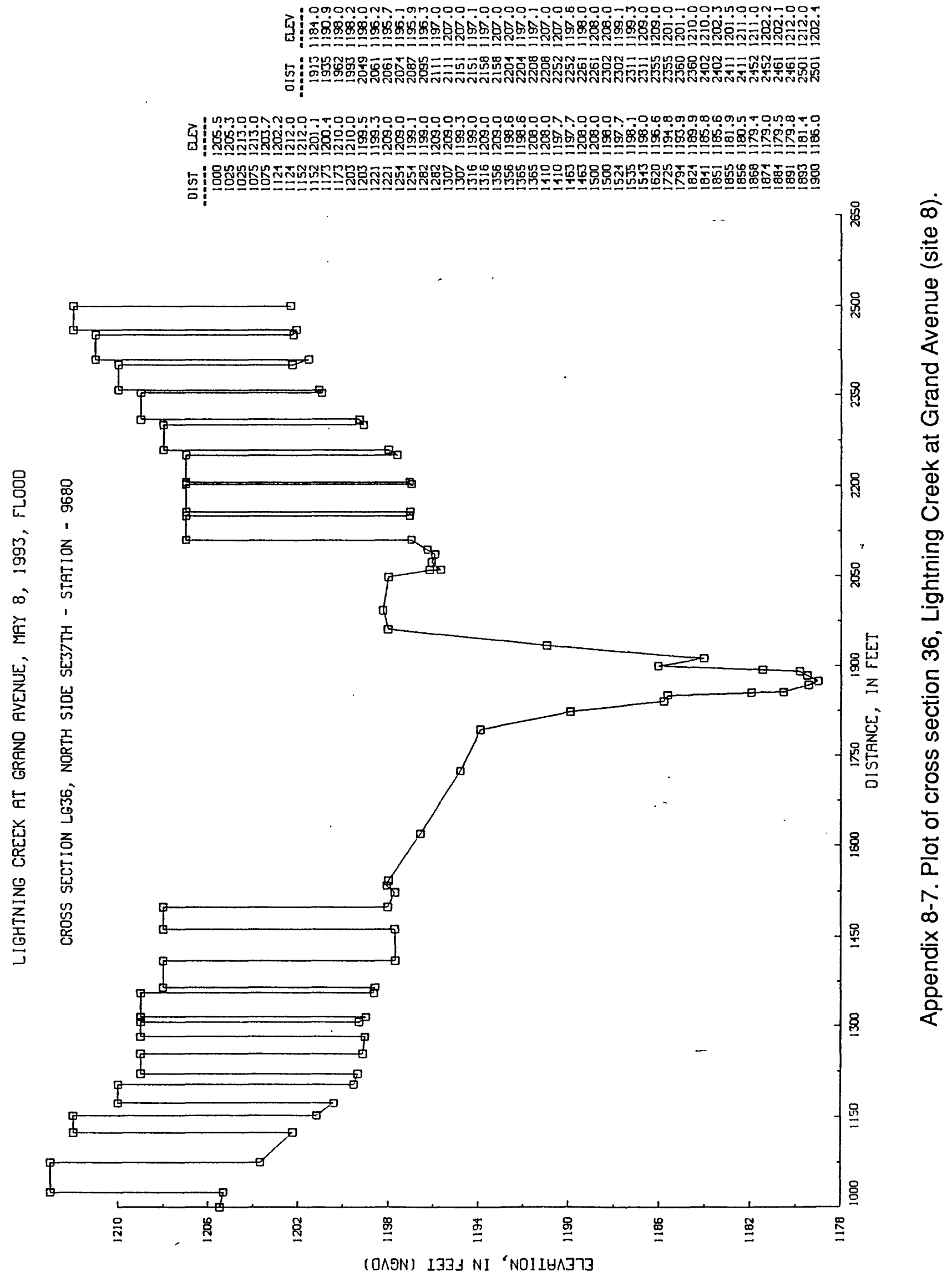




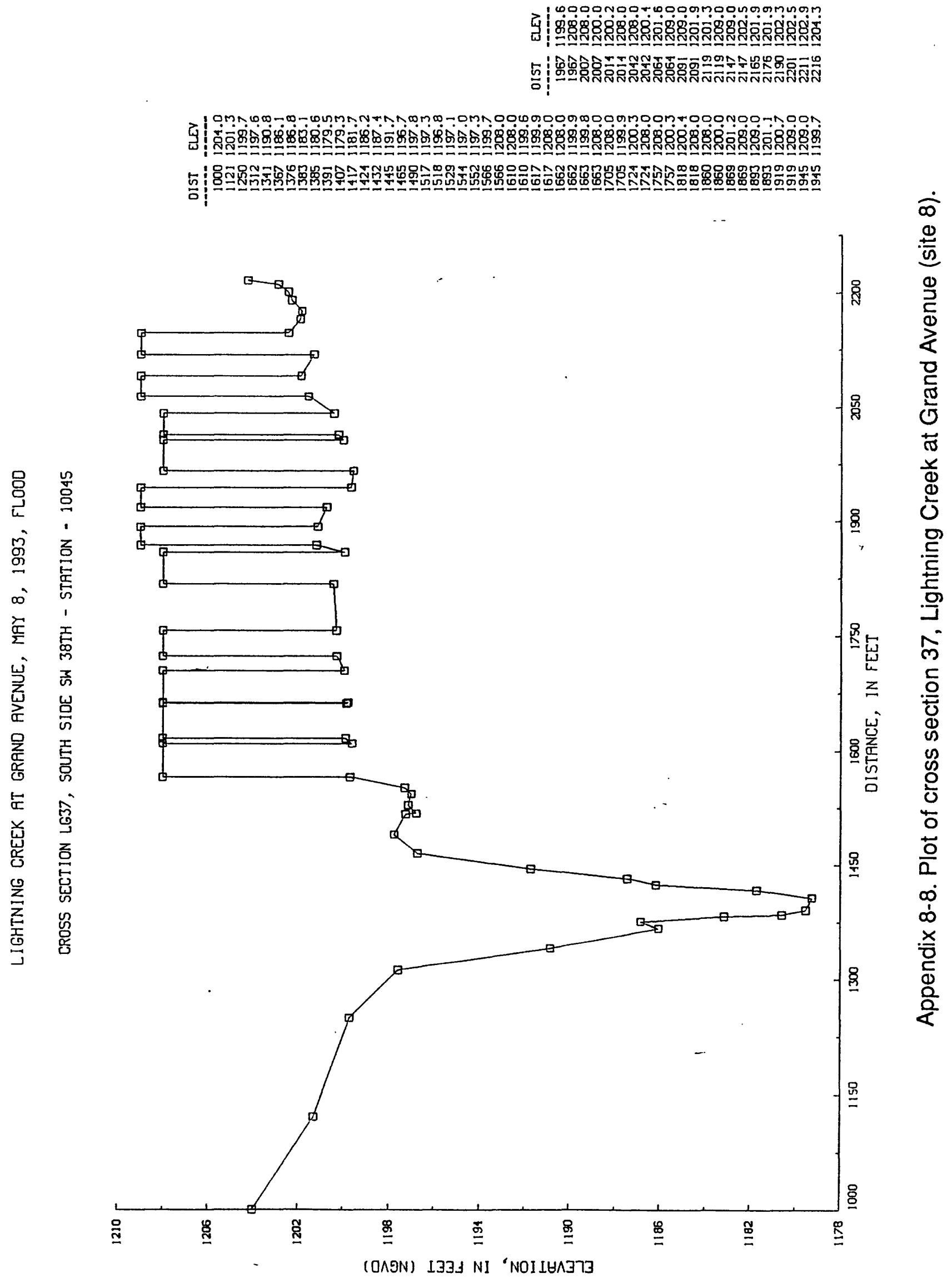




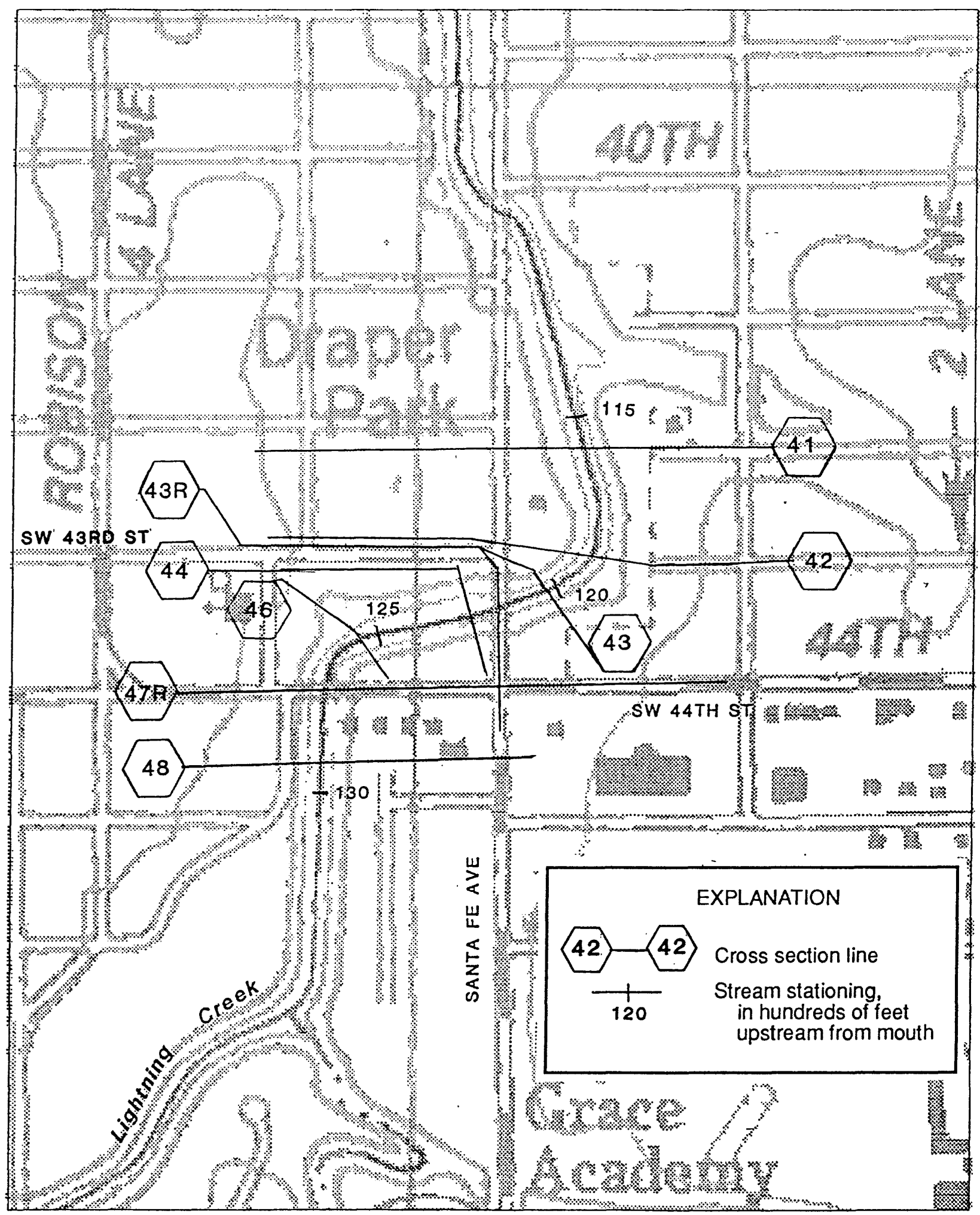

Base from U.S. Geological Survey Digital Raster Graphic, 1:24,000, 1986 Projection: Oklahoma Coordinate System, north zone (Lambert Conformal Conic) 


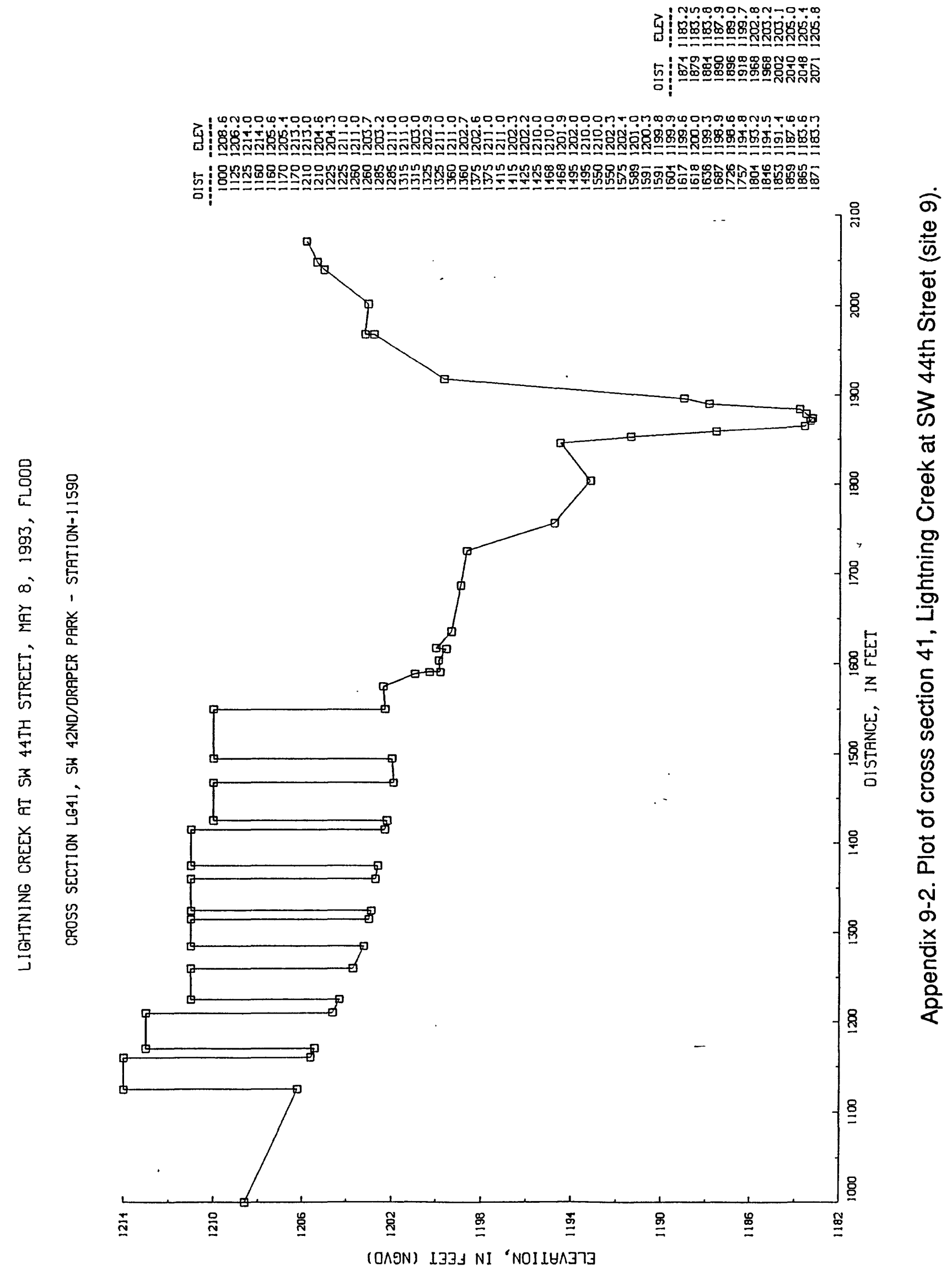




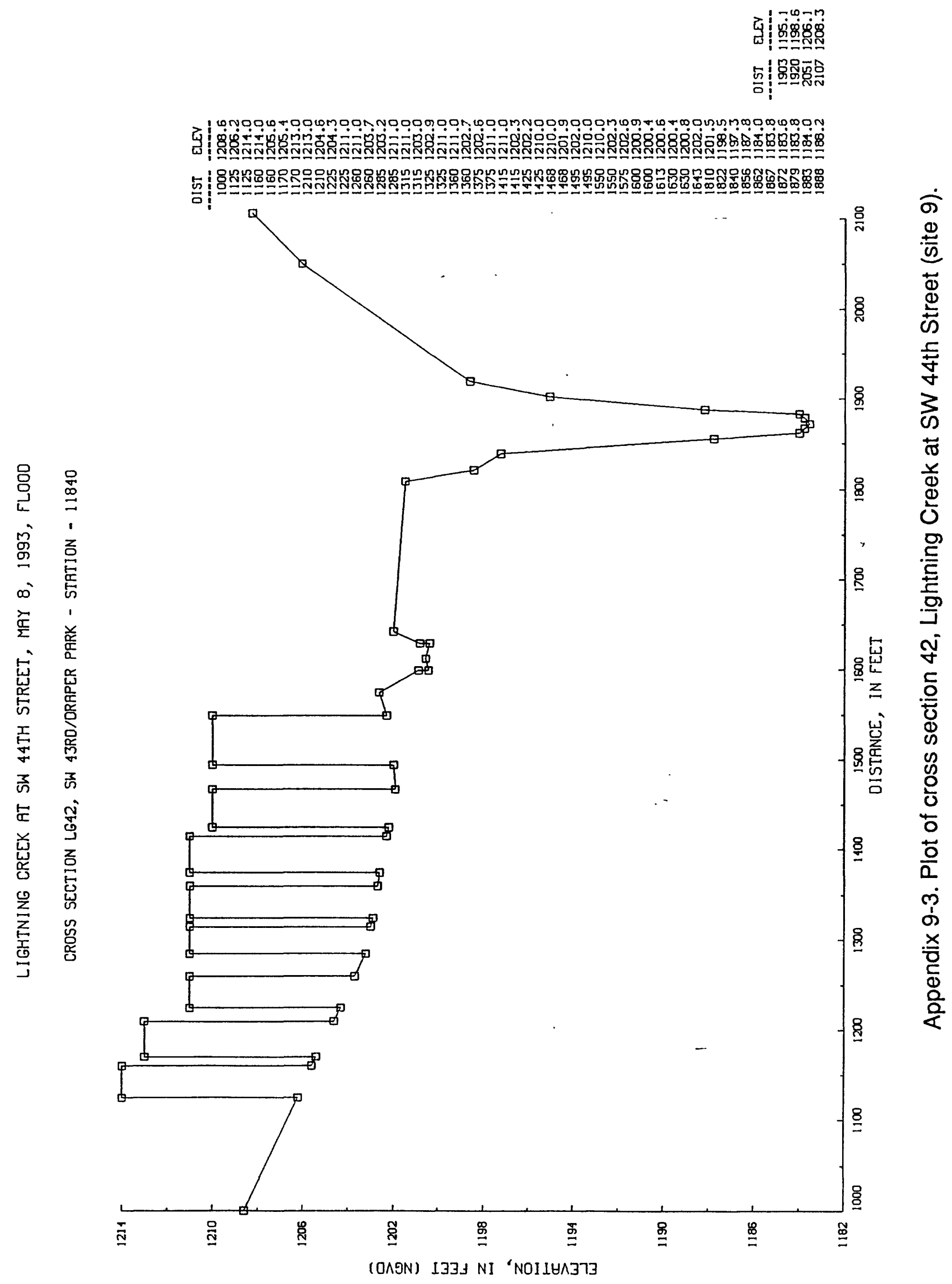




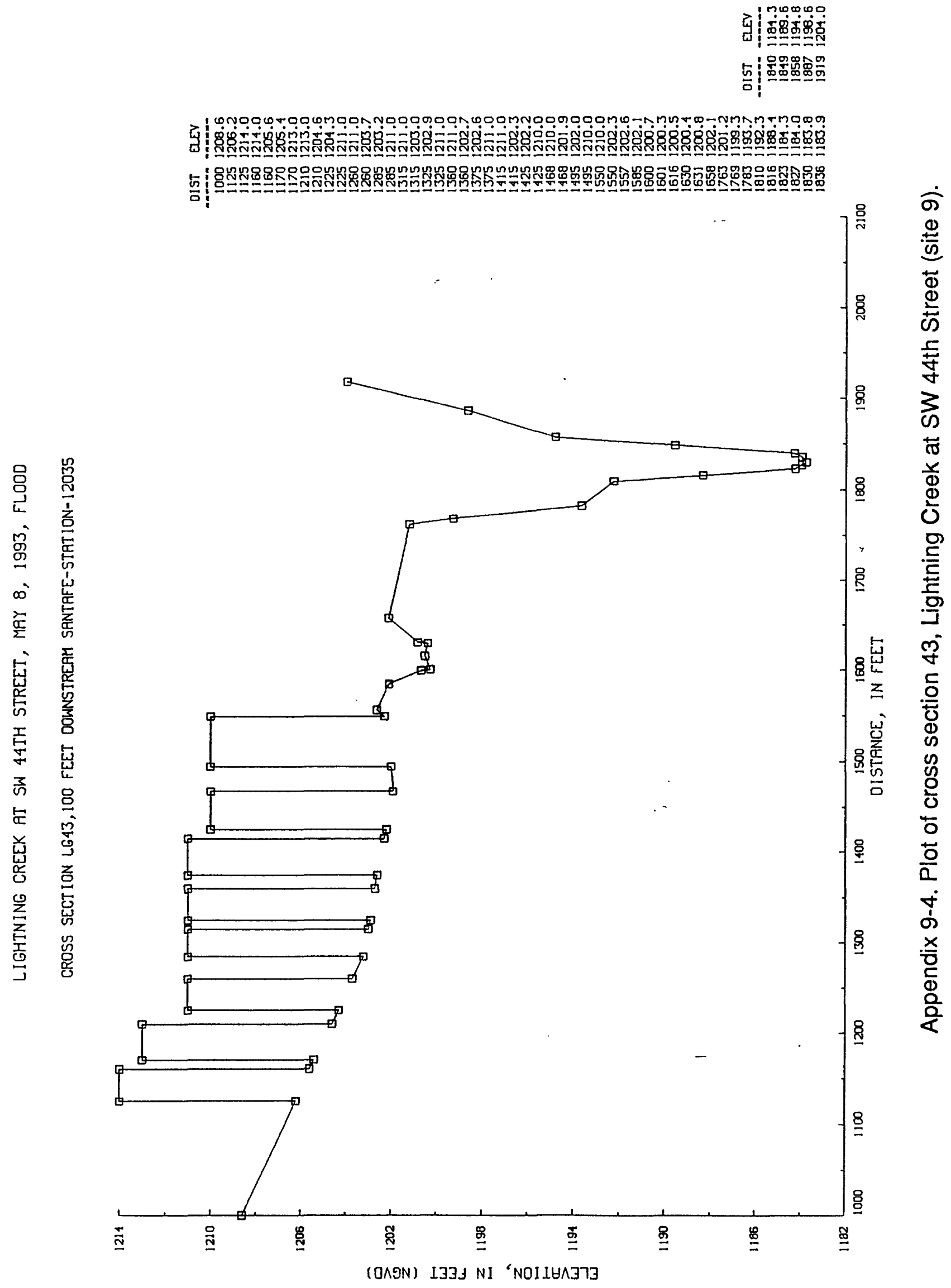




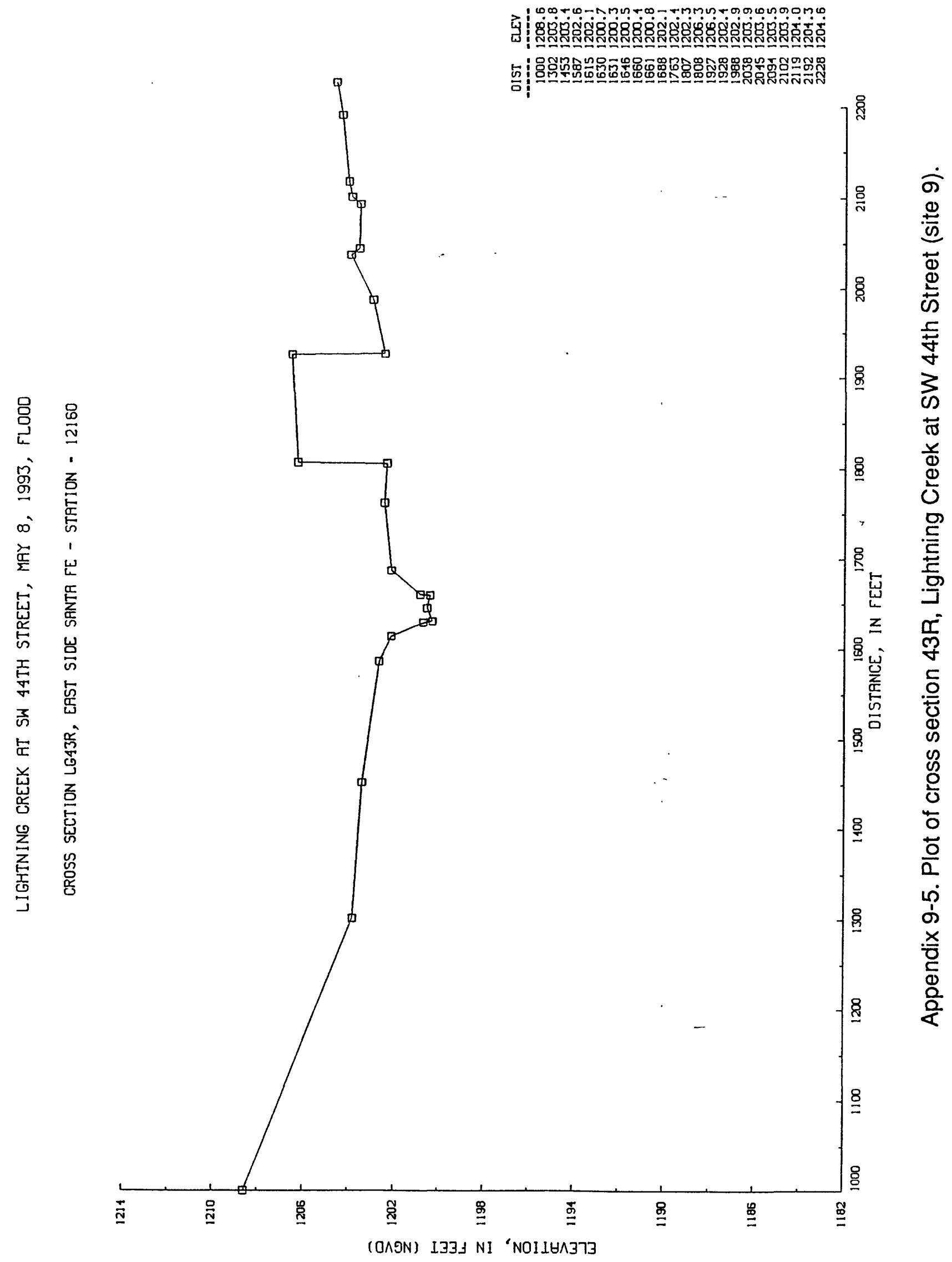

114 Estimated flood peak discharges southwest Oklahoma City, Oklahoma, May 8, 1993 


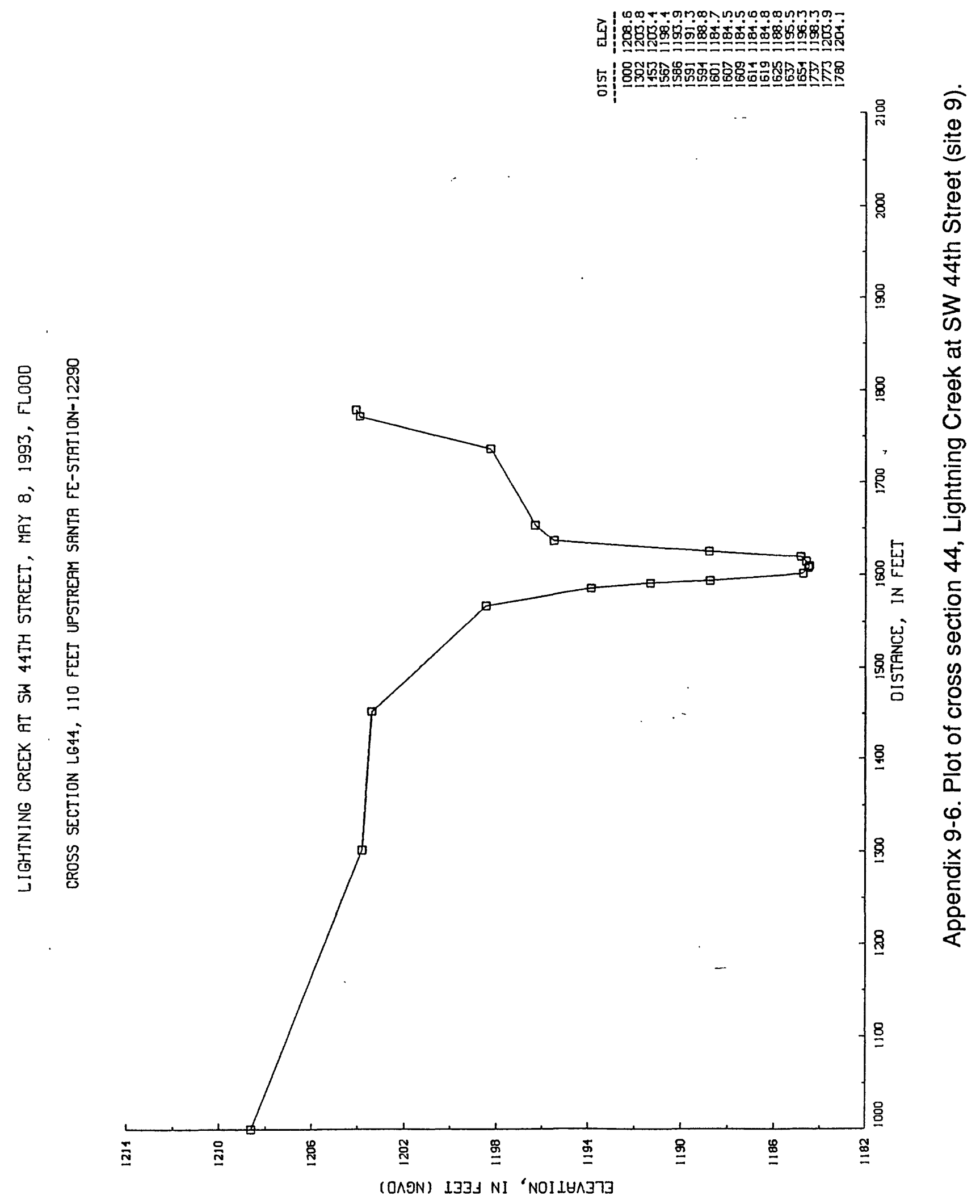




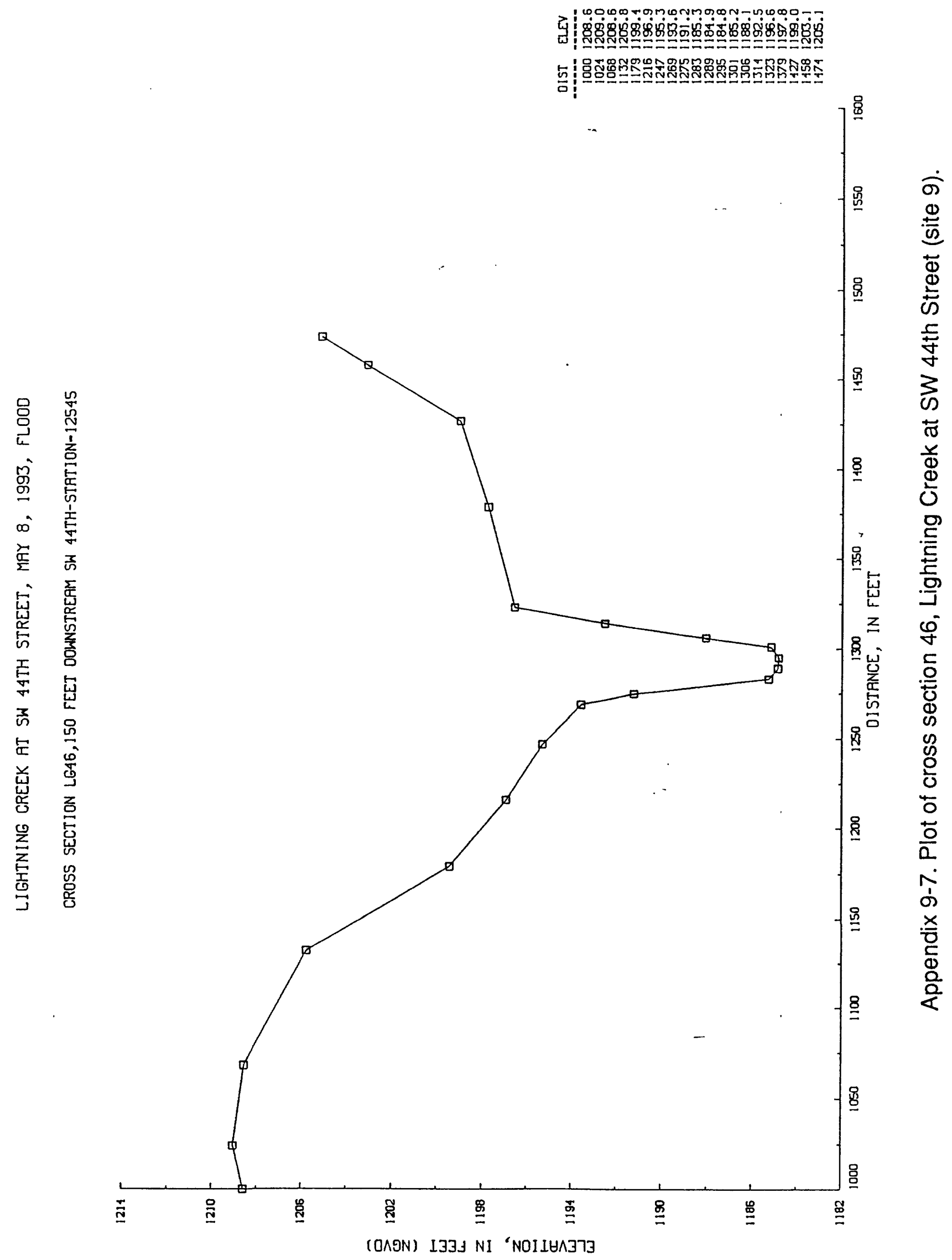




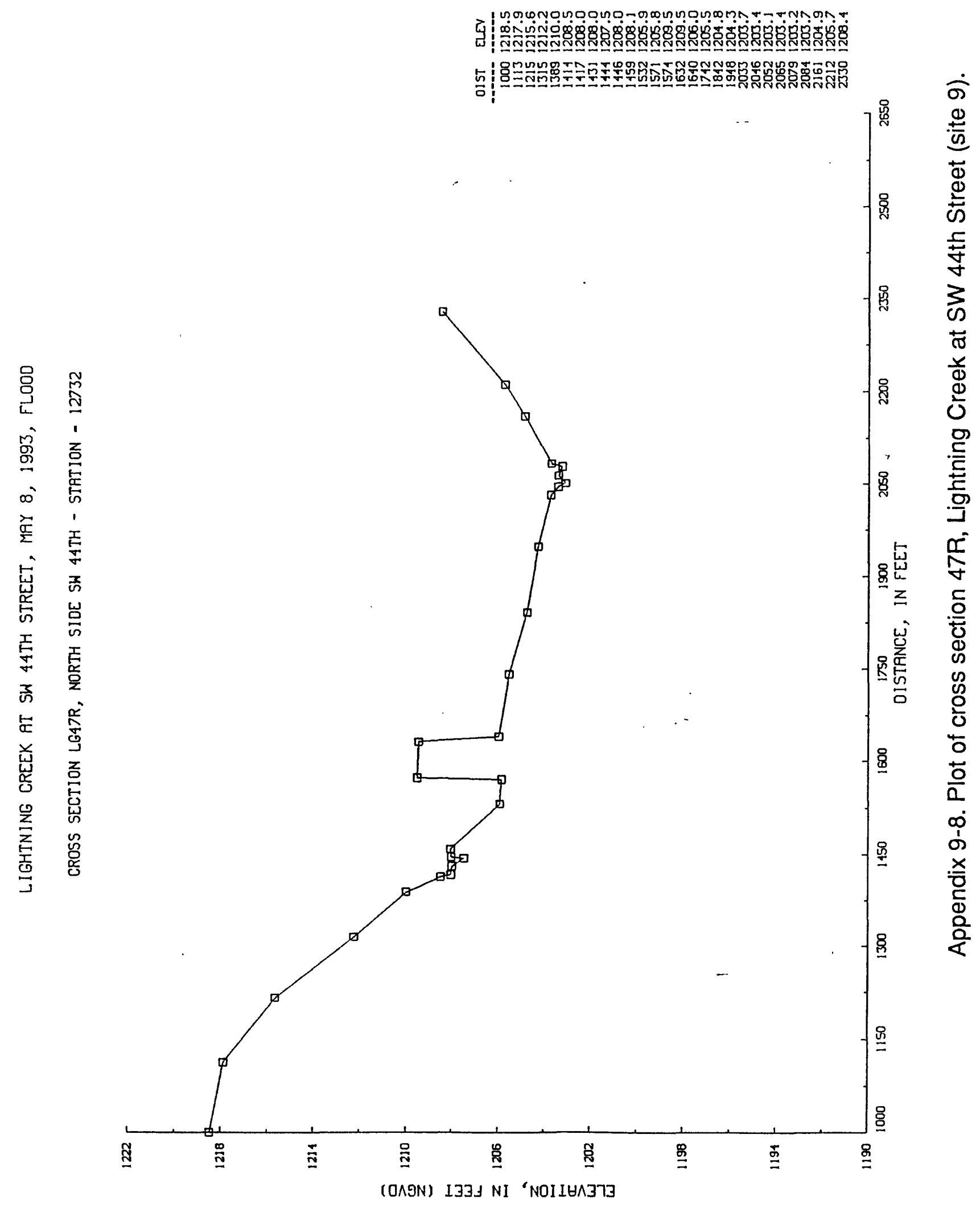




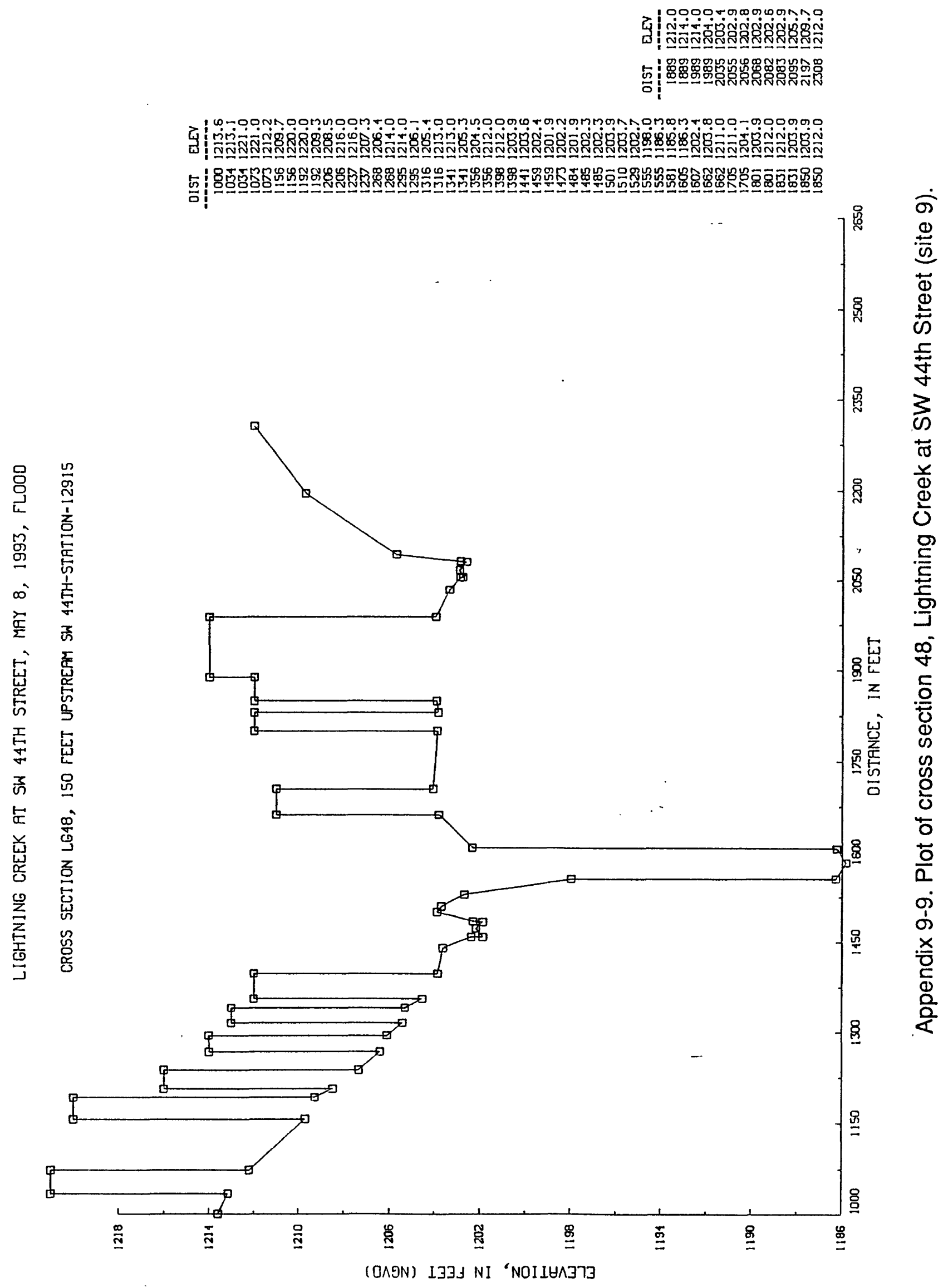




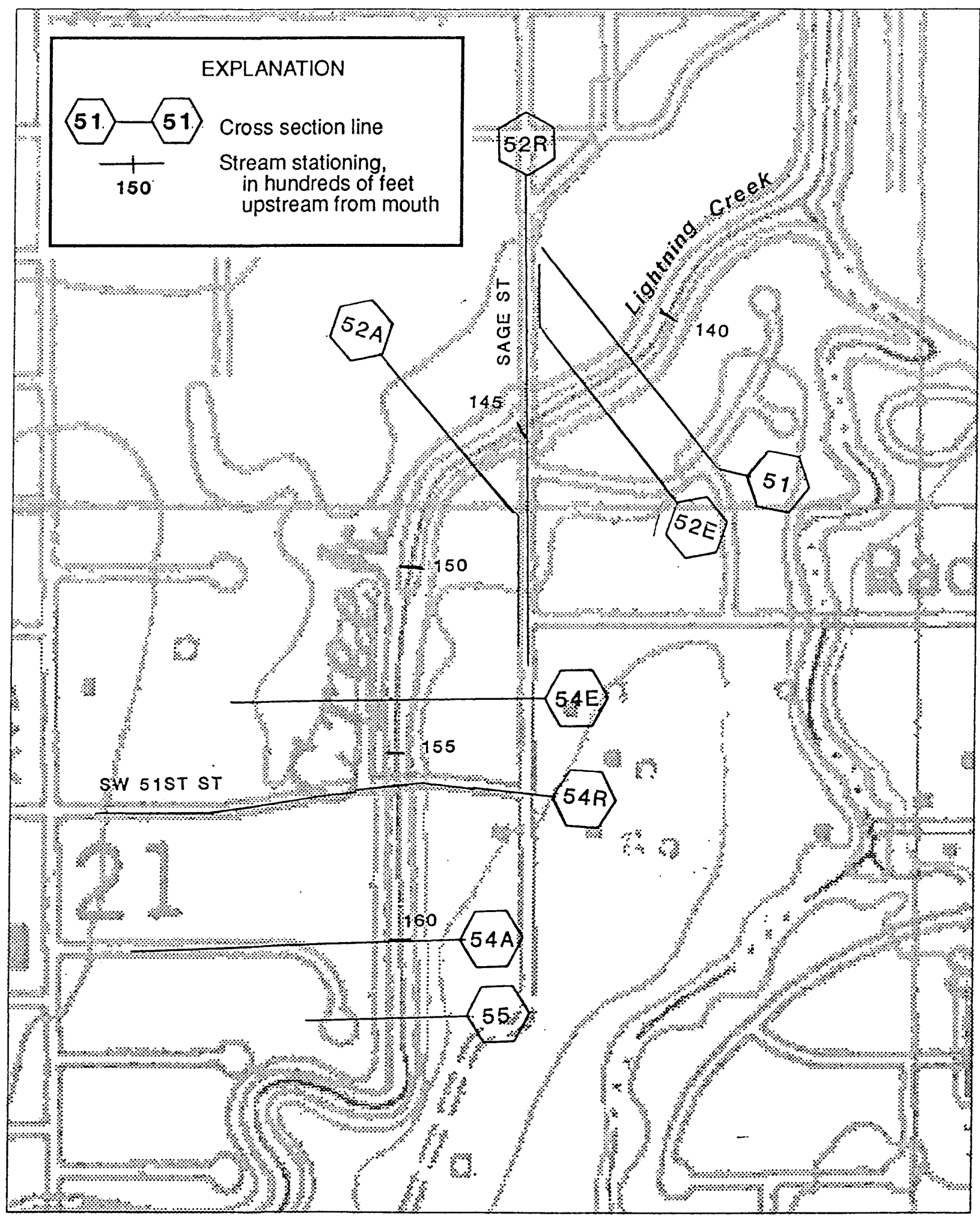

Base from U.S. Geological Survey Digital Raster Graphic, 1:24,000, 1986 Projection: Oklahoma Coordinate System, north zone (Lambert Conformal Conic)

Appendix 10-1. Location of study cross sections on Lightning Creek at Sage Street (site 10), and SW 51st Street (site 11). 


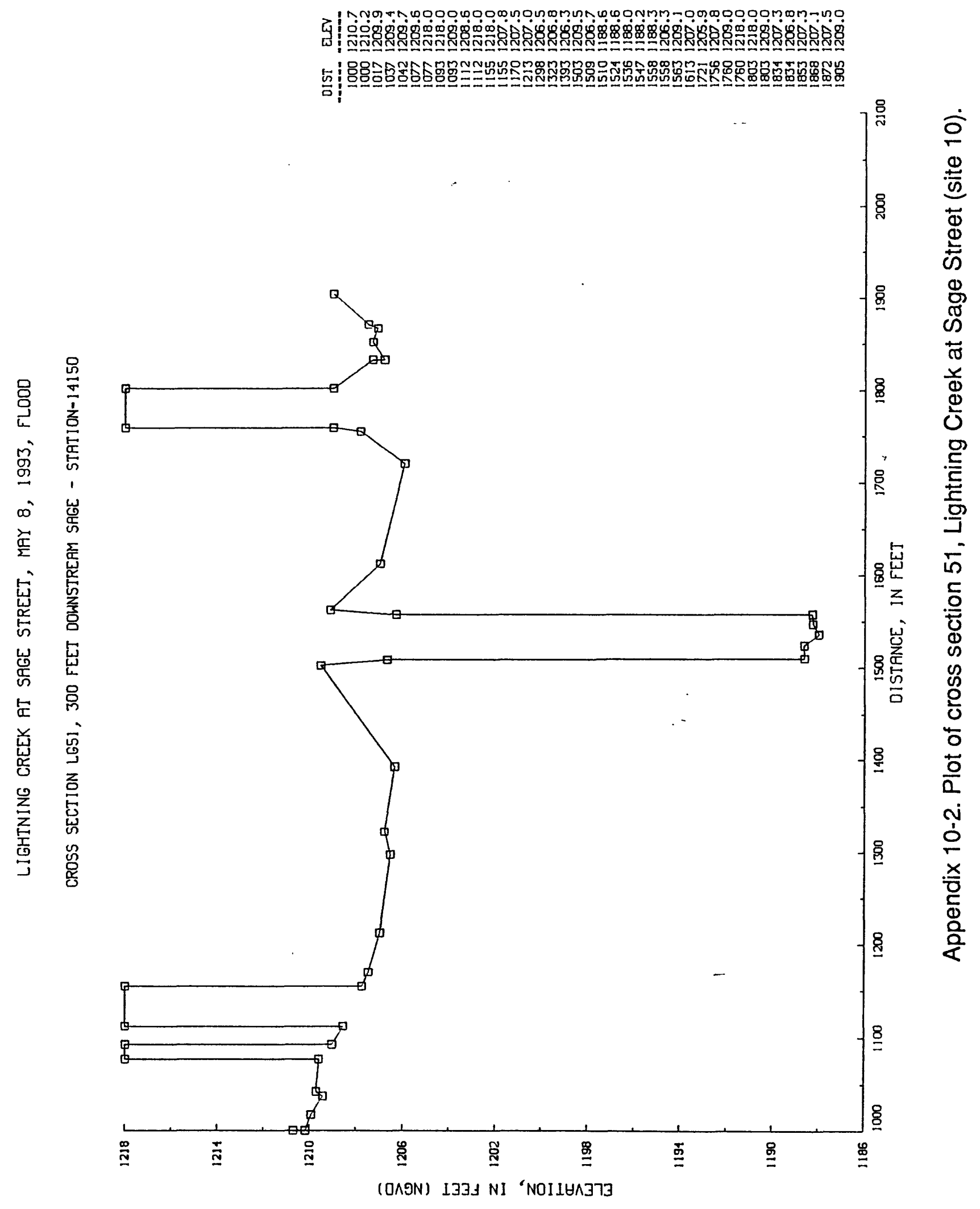




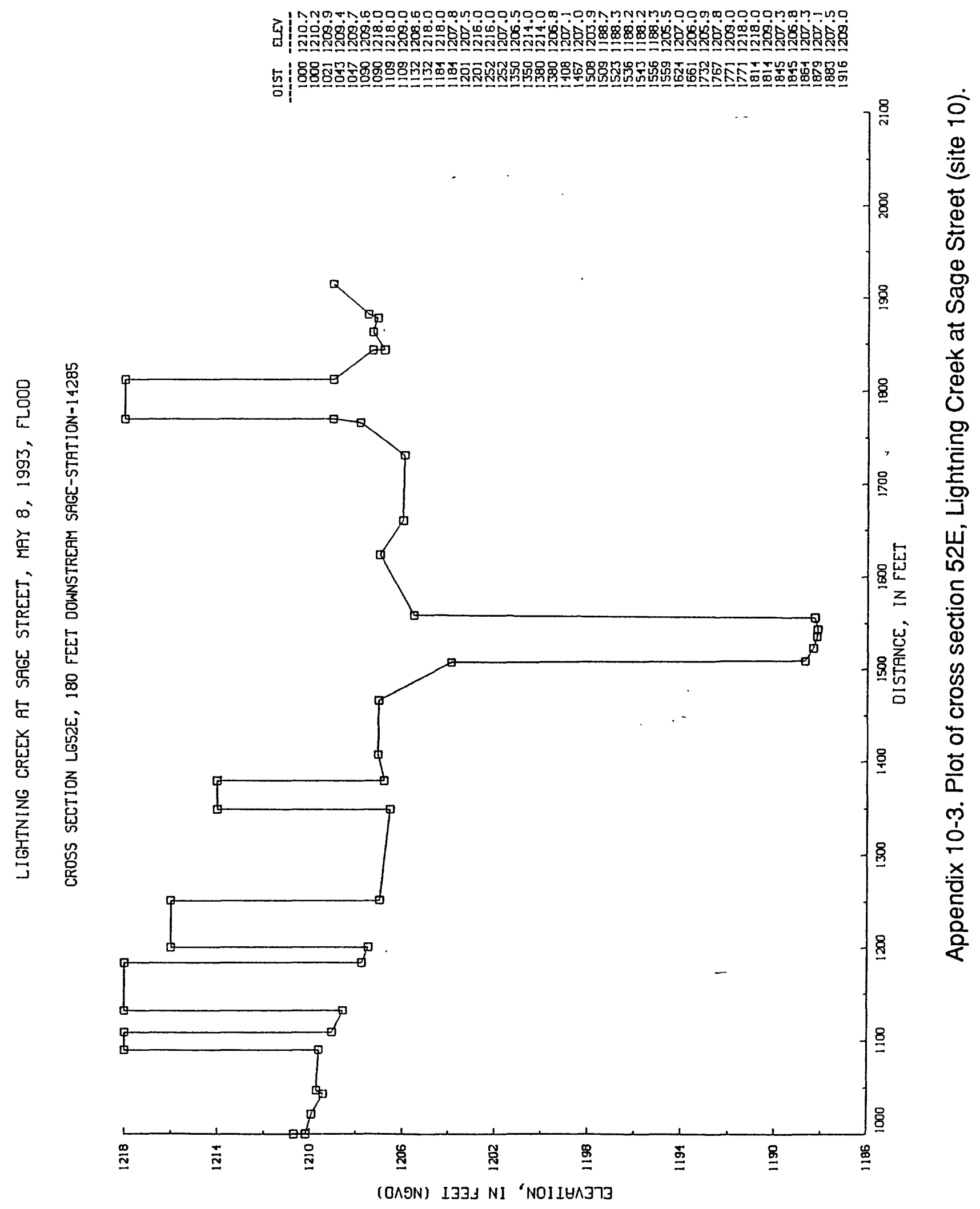




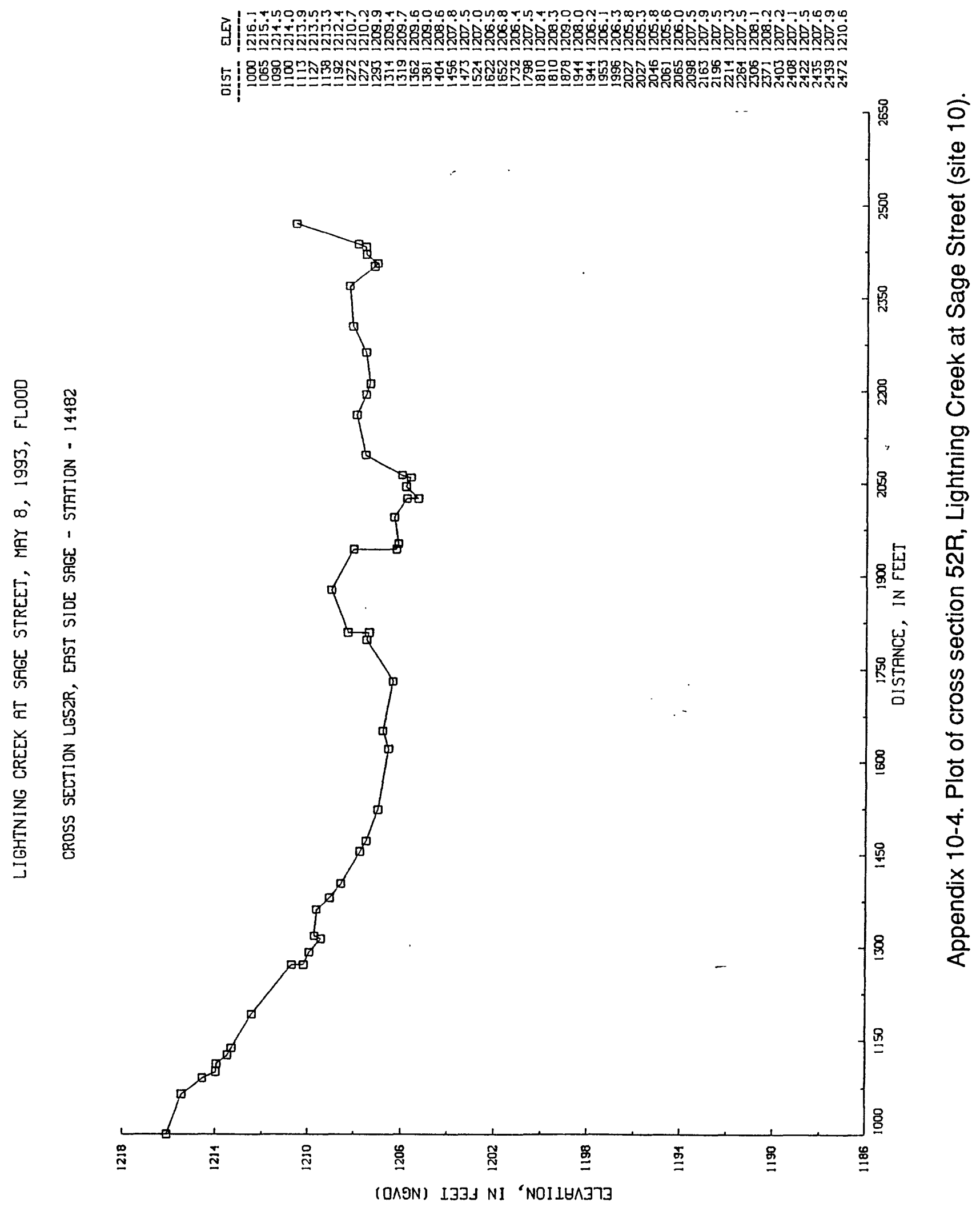




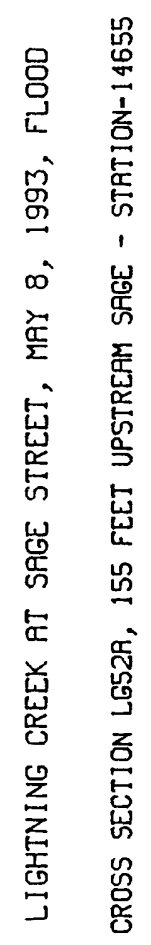

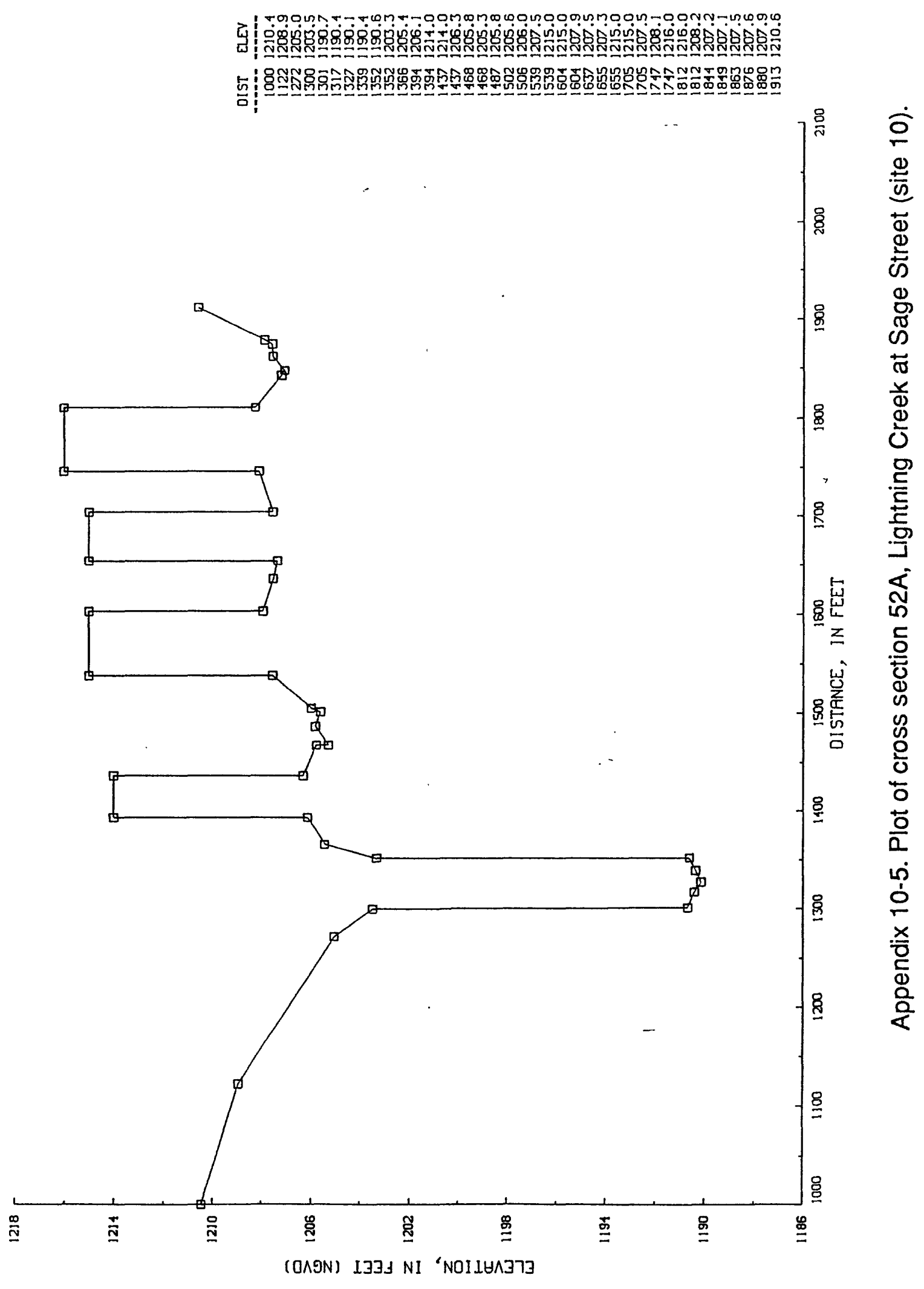




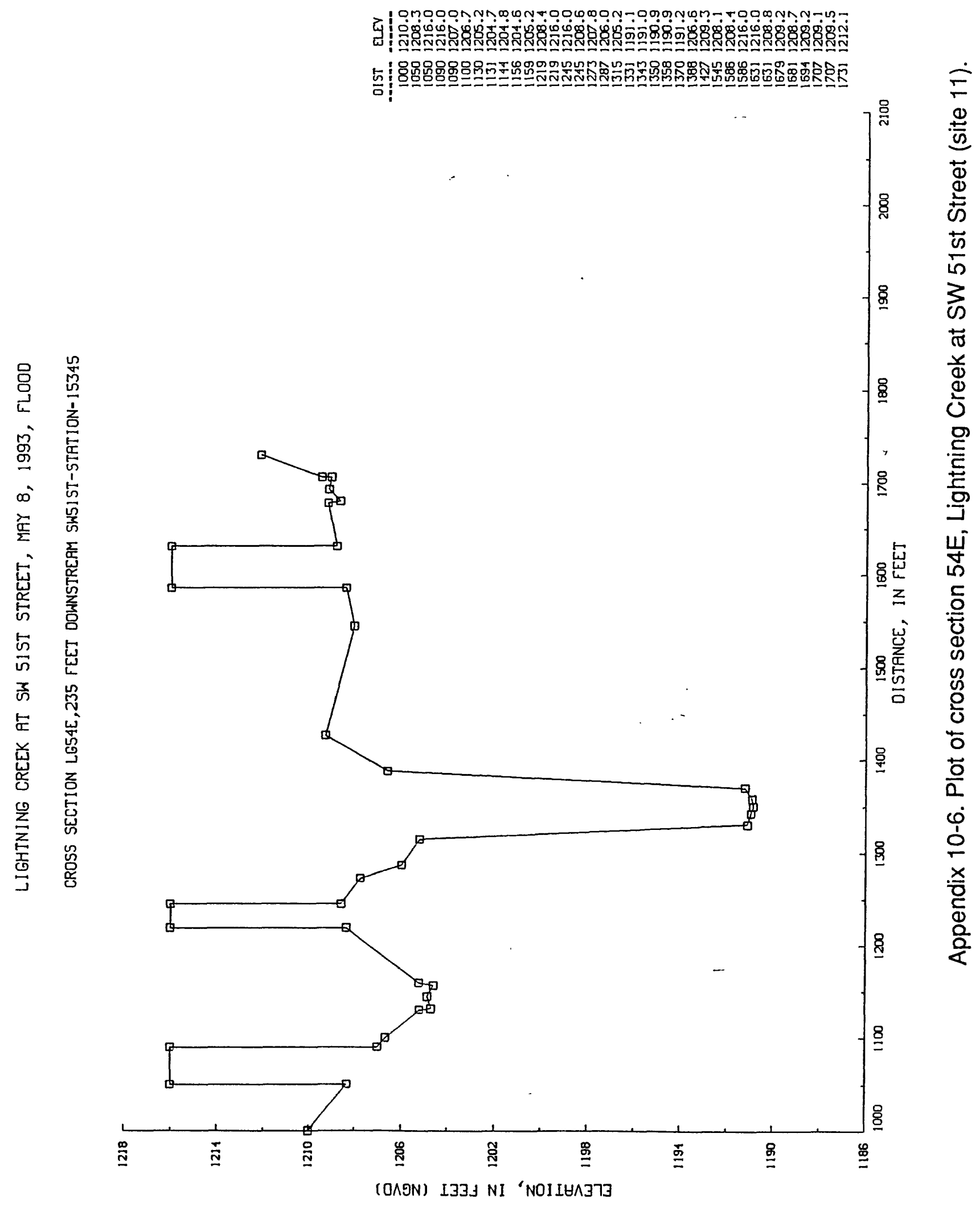




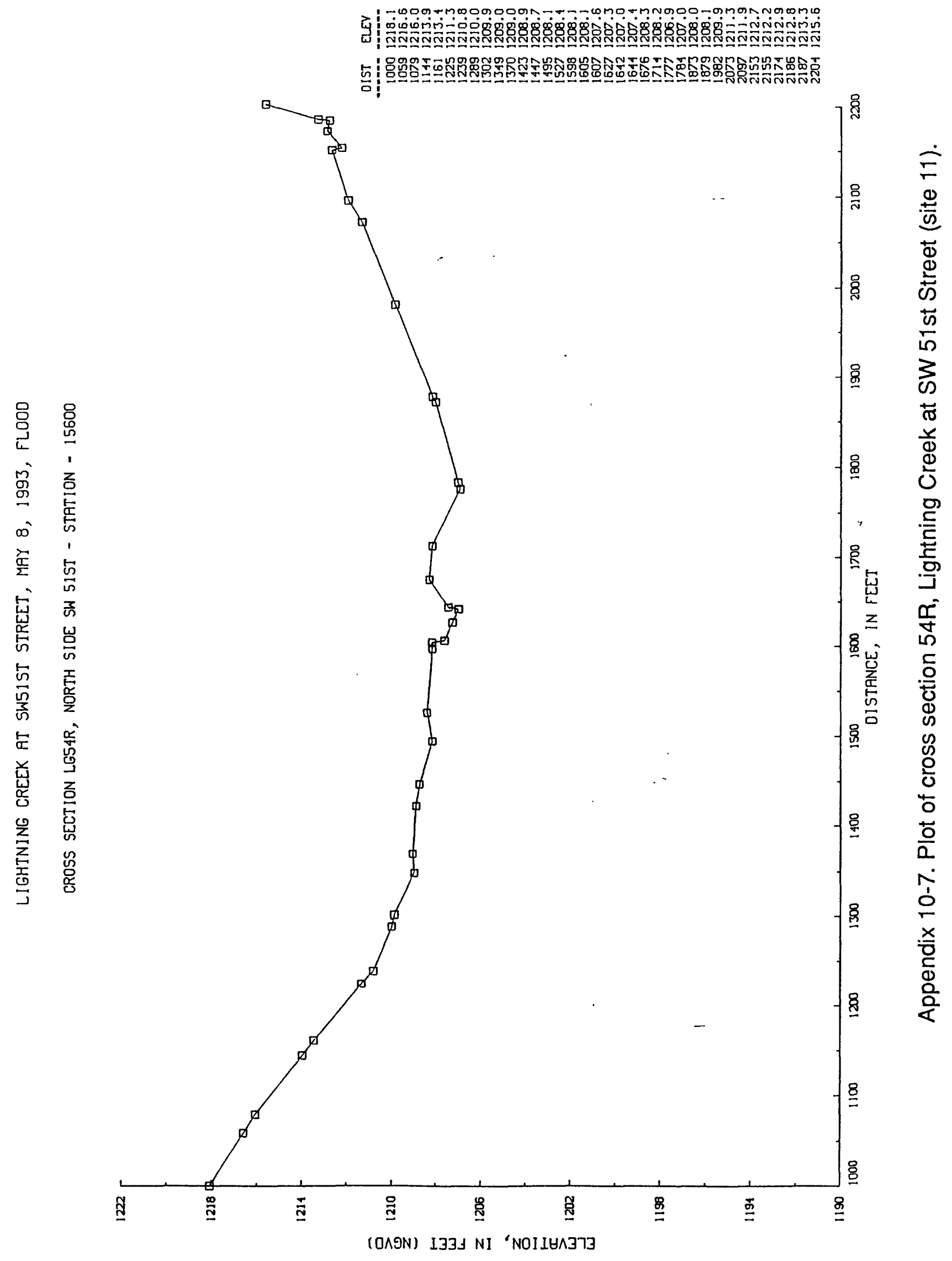




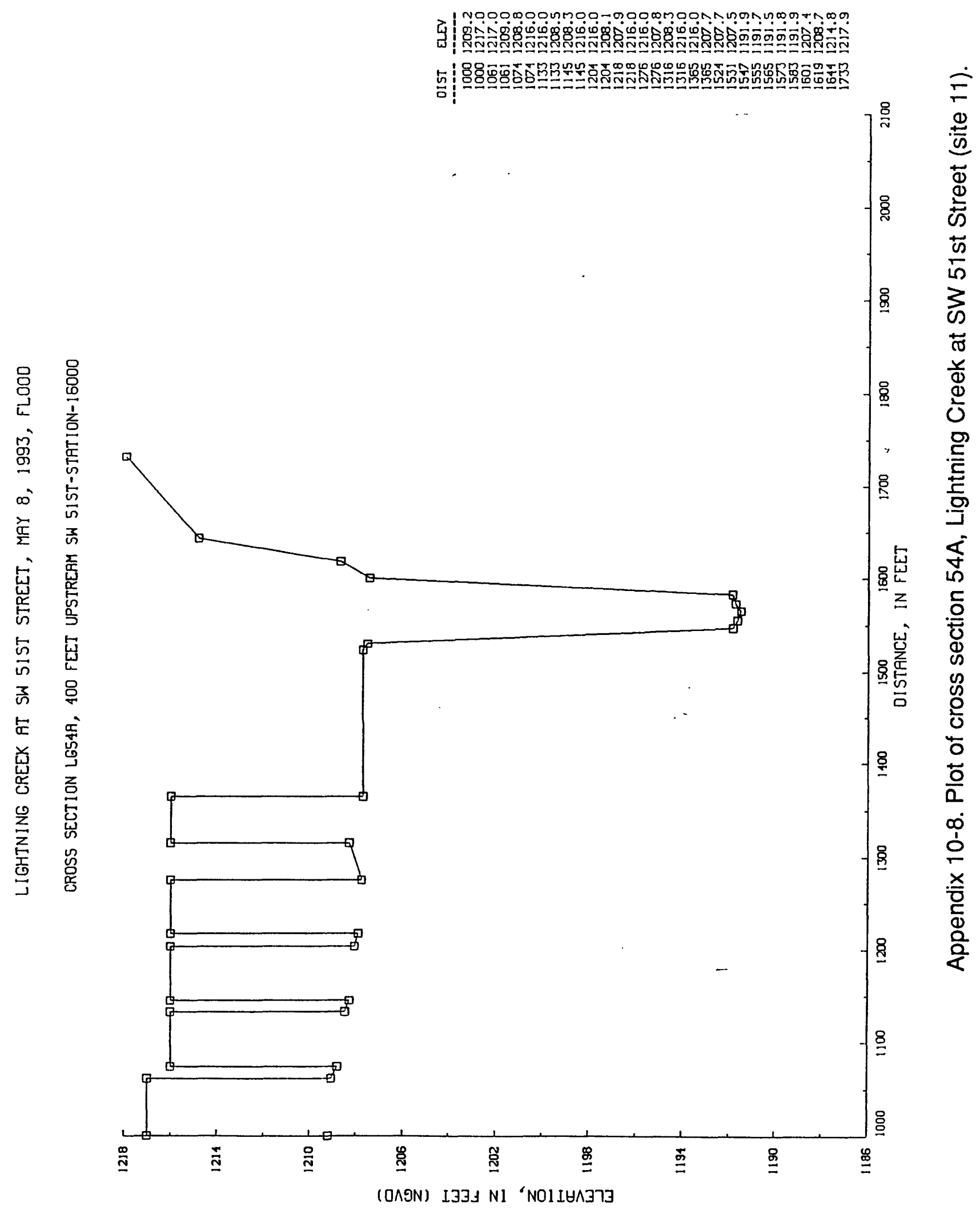




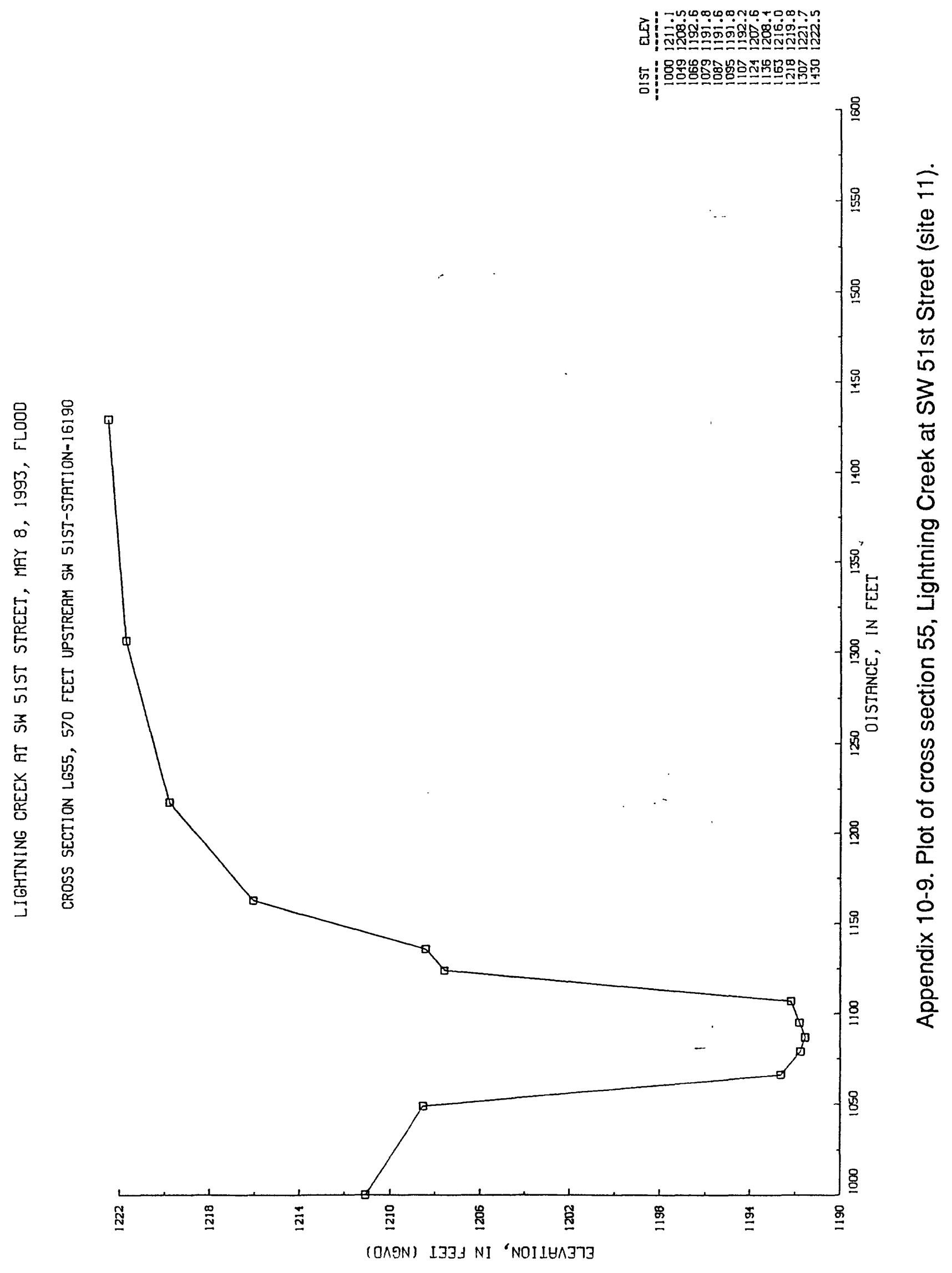

